\title{
Three Essays on Social Assistance in Canada: A Multidisciplinary Focus on Ontario Singles
}

\author{
by
}

Nicholas Falvo

A thesis submitted to the Faculty of Graduate and Postdoctoral
Affairs in partial fulfillment of the requirements for the degree of

Doctor of Philosophy

in

Public Policy

Carleton University

Ottawa, Ontario

(C) 2015

Nicholas Falvo 


\begin{abstract}
A single employable adult relying on social assistance in Ontario receives approximately $\$ 7,500$ annually on which to live. Yet, in spite of this very low amount, singles make up Ontario’s fastest growing household group on social assistance. In 2012, a review of the province's social assistance system recommended an immediate $\$ 100$ increase in monthly benefit levels for singles. All of this raises three key questions:

1) How did Ontario's social assistance system develop into its current form?

2) What do social assistance recipients do with increased monthly benefits?

3) To what extent might increased benefit levels lead to higher caseloads?

The present dissertation comprises three essays - each one looking to answer one of the above questions, and each with a different methodological approach. Each essay also has a different geographical focus: the first looks exclusively at Ontario; the second looks at Ontario's welfare system while interviewing a sample of Toronto-based recipients; and the third looks at six provinces, including Ontario.

In the first essay I gave consideration to the emergence and development of Ontario's social assistance system. With the $1965-1975$ period being its ultimate focus, I found that the Great Depression prompted senior levels of government in Canada to spend more on income assistance, and that the strength of Canada's post-World War II economy made it more palatable for both the Canadian and Ontario governments to expand social assistance coverage and increase benefit levels. The 1965-75 period in Ontario makes for a useful case study, largely because it includes the passage of the Canada Assistance Plan and the initial period that followed.
\end{abstract}


For the second essay, I conducted a series of interviews, over time, with 10 Toronto-based men on social assistance, asking each of them detailed questions about their monthly budgets. Five themes emerged from the research, and each theme forms the basis for a hypothesis that may be examined in future research.

For the third essay, I undertook a regression analysis of determinants of social assistance caseloads for single employables across six Canadian provinces over the 19892010 period. Results suggest that the determinant of singles caseloads in a given year with the highest amount of statistical significance is the previous year's caseloads. What is more, of all the independent variables - and aside from the previous year's caseload level—only British Columbia's stricter administrative rules attain five percent significance or better. 


\section{Acknowledgements}

I have been blessed with four excellent committee members. Allan Moscovitch, Patricia O'Campo, Saul Schwartz and Jim Stanford have all shown patience and thoughtfulness while sharing their deep knowledge with me. In addition to helping me with this thesis, Professor Moscovitch took me under his wing in Carleton's School of Social Work, helping me develop a course on affordable housing and homelessness (and helping me teach Social Policy and Administration, his long time 'baby'). I approached Dr. O'Campo out of the blue in 2009 , from which point she gave very generously of her time, teaching me about population health research, qualitative approaches to research, grant-writing and research ethics boards. Professor Schwartz was the overall project supervisor; he helped me conceptualize the entire dissertation and he exerted just the right amount of pressure on me at all stages. Professor Schwartz also oversaw the writing of Essay 3. Jim Stanford was a major reason I started a PhD; and as a member of the committee, he has provided extremely helpful feedback throughout the writing process. Finally, though John Stapleton was not a formal member of my committee, his assistance was extremely helpful at various stages.

My parents instilled in me a strong sense of social justice, urging me to think hard about 'who gets what.' They also insisted that I think critically, and they encouraged me to question authority. Each has been very supportive since the start of my doctoral studies. When I was a child, my father pushed me hard at school and always urged me to think of disenfranchised persons (even though I pretended not to listen to him). My

mother led by example, working on the 'front line' with immigrants and refugees in my 
hometown of Charlottetown; she was often the main source of social support for hundreds of people at any given time.

Bruce Campbell inspired me to see the usefulness of critical public policy when I met him in 1997. He helped me understand that public policy could indeed help change the world. During 10 years of community work in Toronto, a great many individuals helped me 'learn the ropes' of front-line poverty work. They include Nick Saul, who helped me get my first job as a community worker, and Jim Ward, who inspired me to think about both academic and 'on the ground' work at the same time. They also include my excellent colleagues at Central Neighbourhood House, Dixon Hall, Homes First Society, Houselink Community Homes, Toronto Community Hostel and Street Health. They include Wendy Babcock, Peggy Birnberg, Barb Craig, Sandi Facciolo, Rosemary Hardwick, Arthur Manuel, Bruce McDougall and Jacqueline Power-all of whom left us far too young. And they include homeless and marginally-housed persons whom I really should not name, but who changed my life.

Outside of the formal thesis-writing process, many individuals have played important roles in helping me learn and write about public policy. Before I began my $\mathrm{PhD}$, George Fallis not only taught me a housing course at York University; he also agreed to teach me two independent reading courses. Steve Pomeroy deserves a medal for spending hundreds of hours mentoring me on affordable housing policy over the years. Professor Louis-Philippe Rochon re-taught me how to write an academic paper after I had been out of school for a decade; he also would not let me give up in the early parts of my doctoral journey. Prior to my doctoral studies, John Smithin answered 
(literally) hundreds of my questions about macroeconomic policy. Michael Buzzelli, Sean Gadon, Mario Seccareccia and Greg Suttor have also played important roles.

Fellow students in my $\mathrm{PhD}$ program were very supportive as well. I especially wish to acknowledge David Wink, who, while studying social policy in my program, died very unexpectedly at age 30 . His death often served as a reminder that I was lucky to still be a student.

I wish to thank the fine people I had the privilege of working with for the three years I spent on the Executive of Carleton's Graduate Students' Association (Local 78 of the Canadian Federation of Students). I especially wish to acknowledge the work of Phil Robinson; he is the glue that has kept that organization so strong for so many years.

I learned from great professors at Carleton, including Frances Abele, who has been my 'northern policy mentor' since 2009. And I benefitted enormously from staff in Carleton's School of Public Policy, especially Nicole Gaertner.

Martha Attridge Bufton, Frances Montgomery and Scott Turner provided extremely helpful library assistance. Scott Bennett, Peter Graefe, Hugh Shewell and Valerie Tarasuk helped as well, while Vincent St. Martin helped ensure I had a functioning computer at all stages.

Essay 2 would not have been possible without invaluable cooperation from Stephen Hwang, Vicky Stergiopoulos, Gaye Hainsworth, Leslie MacDonald-Hicks, Joe Manion and his staff. Research participants taught me a great deal about poverty and budgeting.

Simon Power, Frances Woolley and Chris Worswick encouraged me to use a quantitative approach to my third essay. Ashley Kearns and Sebastian Mott encouraged 
me to stick with statistics and helped me work with data in the early phases, while Richard Shillington and James Splinter helped take me to the next level. Ron Kneebone and Katherine White answered a vast array of questions pertaining to their own similar research. I would never have obtained administrative caseload data from provinces without invaluable assistance from Robert Bruce, Annie Lan, Blake McNeil, Billie-Jo Morrissette, Sheila Regehr, Fritz-Herbert Remarais, Dianne Richard, Gilles Séguin, Anne Tweddle and Jim Warren. Pierre Fortin, Seth Klein and David Leadbeater have also been helpful at different junctures. During and after the thesis defence, Therese Jennissen provided extremely helpful feedback.

People close to me always did their best to keep me sane and remind me that there is more to life than a thesis. For this, I especially wish to thank Paige Galette. 
Table of Contents

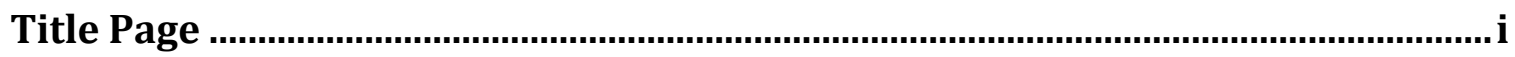

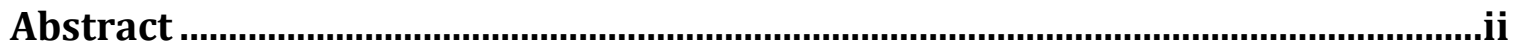

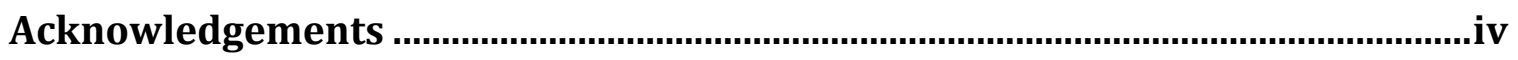

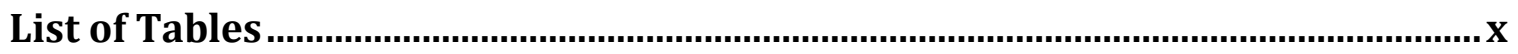

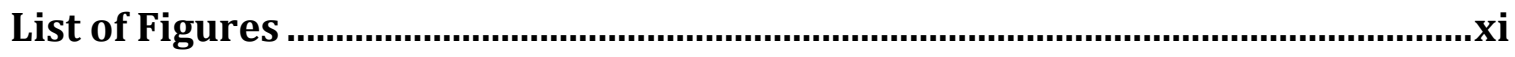

List of Appendices ............................................................................................... $\mathrm{xii}$

List of Abbreviations .............................................................................................. xiii

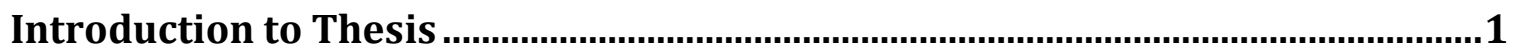

Essay 1: Forging a New Welfare System: The Canada Assistance Plan (CAP) and the Reorganization of Social Assistance in Ontario, 1965-1975....................... 14

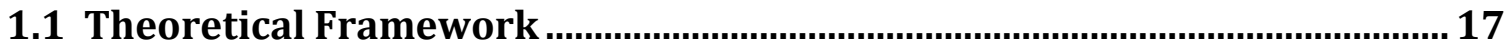

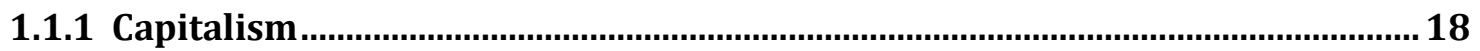

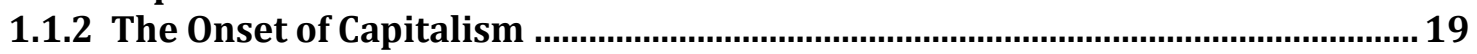

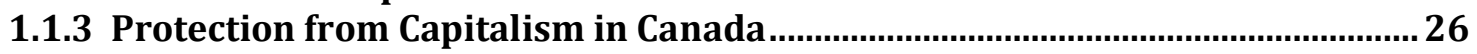

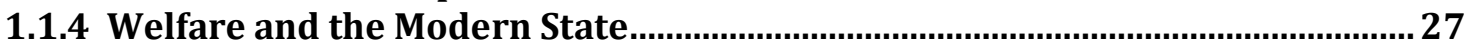

1.2 The Evolution of a Strong State Role in Social Policy ................................... 32

1.2.1 The Impact of the Great Depression .............................................................. 34

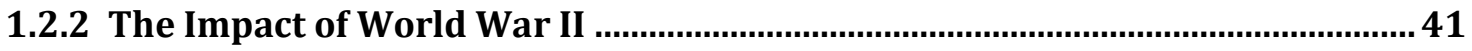

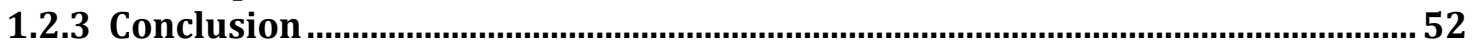

1.3 Ontario's Welfare System: 1965-1975 _.......................................................... 54

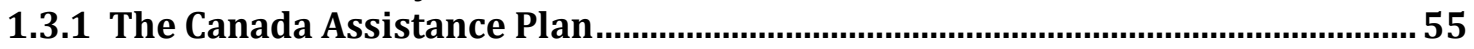

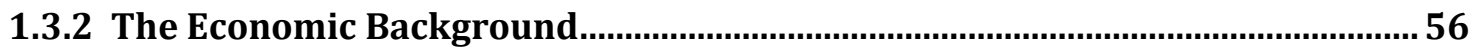

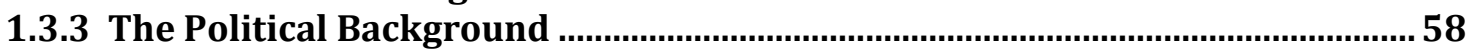

1.3.4 The Framework of the Canada Assistance Plan ................................................60

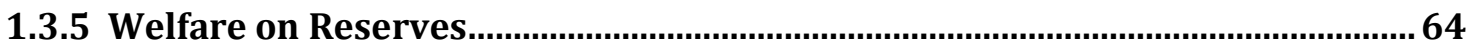

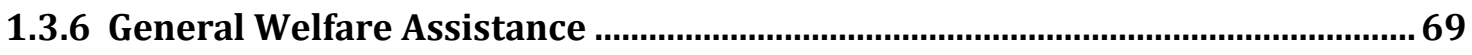

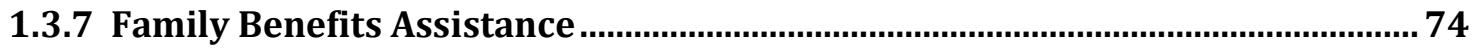

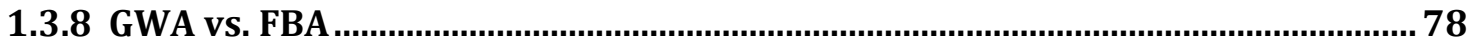

1.3.9 Scope and Generosity of Benefits ....................................................................... 79

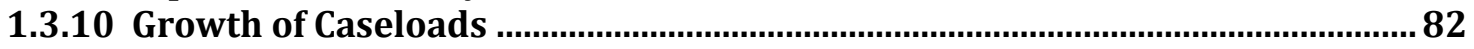

1.3.11 Brief Summation of Development of Ontario's Welfare System, '65-'75...... 90

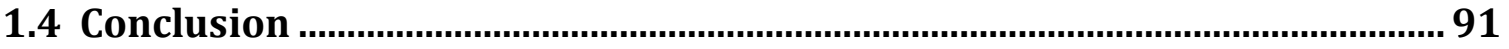

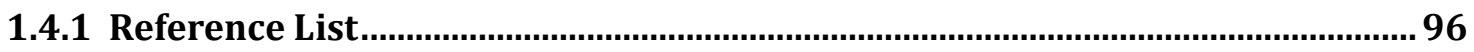

Essay 2: Monthly Purchases of Social Assistance Recipients .........................108

2.1 Methods .....................................................................................................116

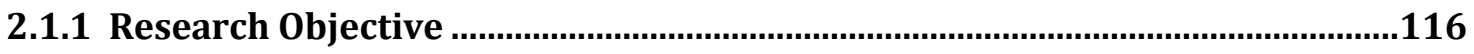

2.1.2 Partnership With Project HOPE...................................................................117

2.1.3 Why Six Interviews per Person? ......................................................................119 


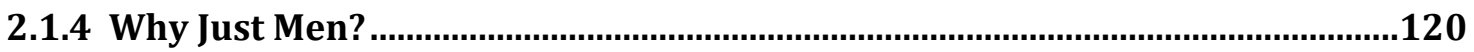

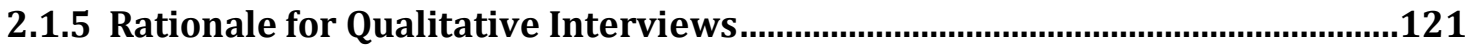

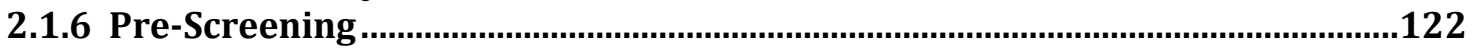

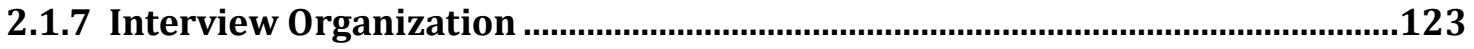

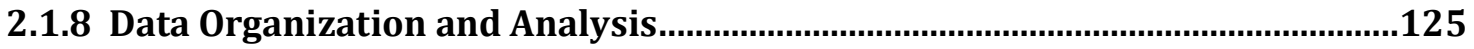

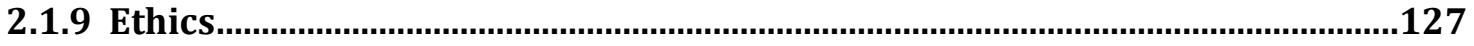

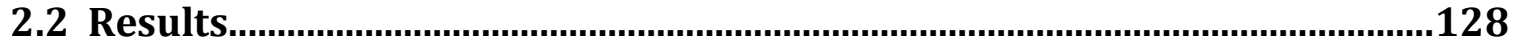

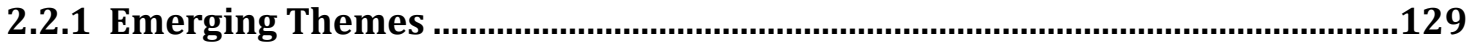

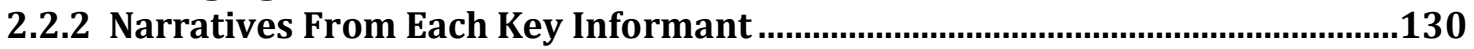

2.2.3 Summary of Expenses by Category .....................................................................134

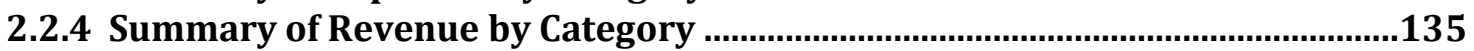

2.2.5 Summary of Health Status .................................................................................137

2.2.6 Self-Reported Challenges With Respect to Food Purchases.............................139

2.2.7 Post-Survey Reflections on Methodology ......................................................140

2.2.8 First Meeting with Program Officials ..........................................................140

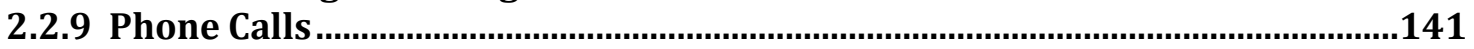

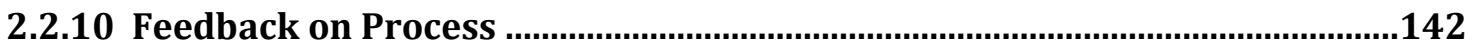

2.3 Discussion ..........................................................................................................145

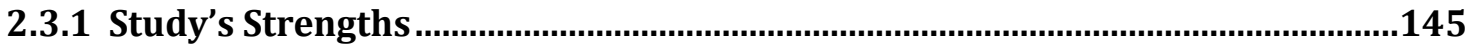

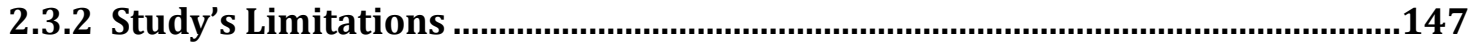

2.3.3 Implications for Future Research ….................................................................148

2.3.3.1 Methodological implications for similar research..................................................149

2.3.3.2 Hypotheses for similar research............................................................................151

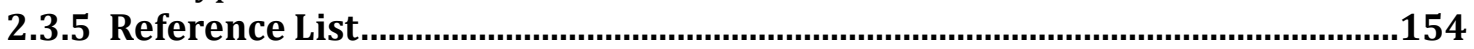

Essay 3: Determinants of Welfare Caseloads for Singles....................................187

3.1 Theoretical Economic Model ........................................................................190

3.2 Theoretical Econometric Model ..................................................................196

3.2.1 Potential Drawbacks of Pooling Cross-Sectional Data.....................................198

3.2.2 Previous Canadian Efforts at Estimating Determinants of Caseloads.............200

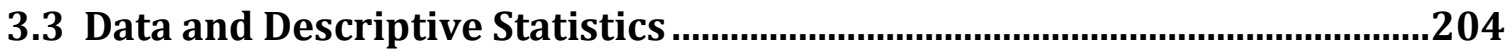

3.3.1 Dependent Variable: Caseloads ....................................................................204

3.3.2 Explaining the Difficulty in Obtaining Caseload Data .........................................206

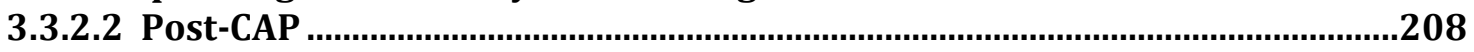

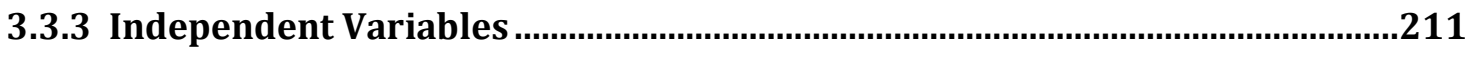

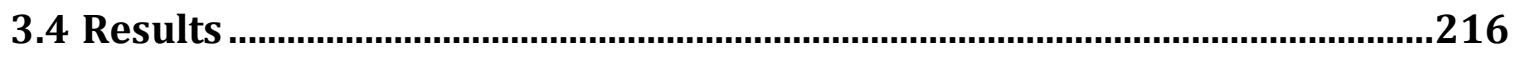

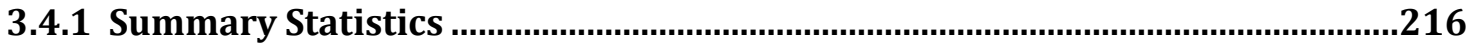

3.4.2 Initial Regression Results ..............................................................................217

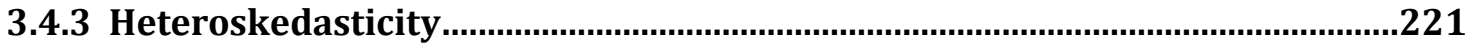

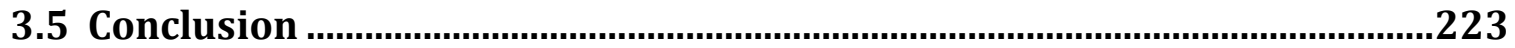

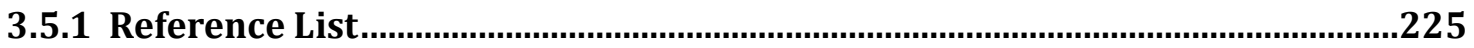

Conclusion to Thesis........................................................................................244 


\section{List of Tables}

Table 1.1. Implications of CAP on Direct Financial Assistance to Persons in Ontario.................61

Table 1.2. Main Components of General Welfare Allowance, 1970 ............................................ 71

Table 1.3. Monthly earnings exemptions for GWA recipients, 1970 ............................................ 73

Table 1.4. Monthly earnings exemptions for FBA recipients, 1970 ..................................................... 77

Table 1.5. Relief Disbursements by Financial Arrangement, 1931-1937.................................... 105

Table 1.6. Relief Disbursements by Level of Government, 1931-1937.......................................... 106

Table 2.1. Monthly Spending by Mothers on Social Assistance (Edin and Lein, 1997) ................... 114

Table 2.2. Biggest Problems When it Comes to Food Purchases ..................................................... 139

Table 2.3. Monthly Expenses by Category (in Dollars) ............................................................. 169

Table 2.4. Monthly Expenses by Category (as a Percentage of Total Monthly Expenses)................ 170

Table 2.5. Monthly Revenue by Category (in Dollars) .................................................................... 171

Table 2.6. Monthly Revenue by Category (as a Percentage of Total Monthly Revenue)................. 172

Table 2.7. Results of SF-36v2 Health Survey .................................................................................... 173

Table 3.1. Singles Caseloads, 1989 and 2010 - Totals and Rates.................................................... 206

Table 3.2. Singles Caseloads, Six Provinces (1989-2010)................................................................ 210

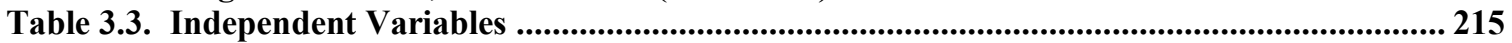

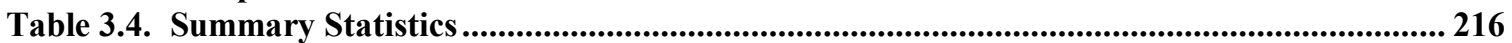

Table 3.5. Regression Coefficients for the SA Rate 1989-2010 .................................................. 218

Table 3.6. Regression Coefficients for the SA Rate After Correcting for Heteroskedasticity .......... 222

Table 3.7. Data Matrix............................................................................................................................. 238

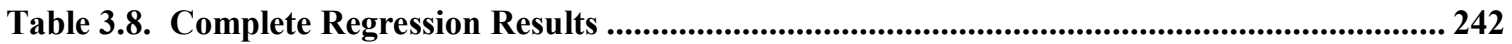




\section{List of Figures}

Figure 1.1. Federal-Provincial Shareable Expenditures of Direct Financial Assistance to Persons in

Canada.

Figure 1.2. Federal Social Assistance Payments for Registered Indians..............................67

Figure 1.3. Federal Payments (Social Services) for Registered Indians...............................68

Figure 1.4. GWA Benefit Levels, 1961-1976..........................................................80

Figure 1.5. FBA Benefit Levels, 1961-1976......................................................81

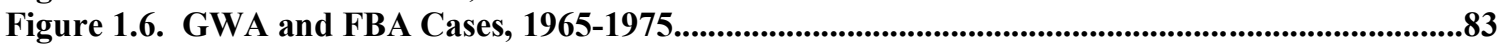

Figure 1.7. GWA Cases by Reason................................................................................................8 84

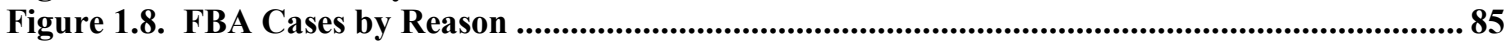

Figure 1.9. Annual GWA Expenditures, Ontario.....................................................................8 86

Figure 1.10. CAP Federal-Provincial Cost-Shared Payments of Direct Financial Assistance..........88

Figure 1.11. Federal-Provincial Cost-Shared Payments Under CAP for "Other Welfare Services and

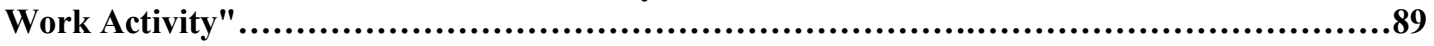

Figure 1.12. Unemployment Rate, Canada and Ontario 1946-1975 ............................................ 107

Figure 3.1. Constrained Utility Maximization ................................................................................. 191

Figure 3.2. The Effect of an Increase in Nonlabour Income on Labour Supply ............................ 192

Figure 3.3. Substitution and Income Effects of a Wage Increase .................................................... 193

Figure 3.4. SA Caseload and SA Rate for Singles, Newfoundland and Labrador, 1989-2010........232

Figure 3.5. SA Caseload and SA Rate for Singles, New Brunswick, 1989-2010.....................233

Figure 3.6. SA Caseload and SA Rate for Singles, Quebec, 1989-2010.............................234

Figure 3.7. SA Caseload and SA Rate for Singles, Ontario, 1989-2010 ......................................... 235

Figure 3.8. SA Caseload and SA Rate for Singles, Saskatchewan, 1989-2010................................ 236

Figure 3.9. SA Caseload and SA Rate for Singles, British Columbia, 1989-2010.......................... 237 


\section{List of Appendices}

Appendix 1.1. Relief Disbursements by Financial Arrangement, 1931-1937.........................105

Appendix 1.2. Relief Disbursements by Level of Government, 1931-1937.............................106

Appendix 1.3. Unemployment Rate, Canada and Ontario, 1946-1975 ................................107

Appendix 2.1. Brief description of proposed research...............................................157

Appendix 2.2. Description of proposed research...............................................158

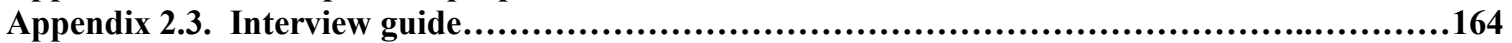

Appendix 2.4. Monthly expenses by category (in dollars) .......................................169

Appendix 2.5. Monthly expenses by category (as a percentage of total monthly expenses)..............170

Appendix 2.6. Monthly revenue by category (in dollars)..............................................171

Appendix 2.7. Monthly revenue by category (as a percentage of total monthly revenue)...............172

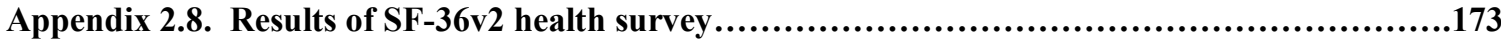

Appendix 2.9. Deviations from original plan..................................................174

Appendix 2.10. City of Toronto letter of support................................................176

Appendix 2.11. Letter from City of Toronto to potential interview subjects..........................177

Appendix 2.12. Flyer given to potential interview subjects..........................................178

Appendix 2.13. Letter of information..........................................................179

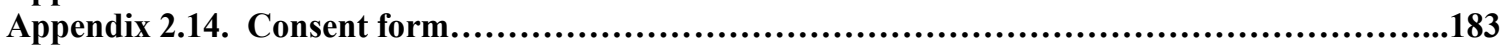

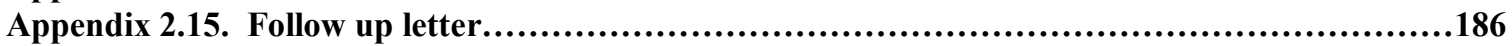

Appendix 3.1. Detailed Descriptions of Caseload Data Sources...................................227

Appendix 3.2. Detailed Descriptions of Data Sources for Independent Variables.....................230

Appendix 3.3. SA Caseload and SA Rate, Singles, 1989-2010, Newfoundland and Labrador.........232

Appendix 3.4. SA Caseload and SA Rate for Singles, New Brunswick, 1989-2010...................233

Appendix 3.5. SA Caseload and SA Rate for Singles, Quebec, 1989-2010 ..........................234

Appendix 3.6. SA Caseload and SA Rate for Singles, Ontario, 1989-2010 ...........................235

Appendix 3.7. SA Caseload and SA Rate for Singles, Saskatchewan, 1989-2010.....................236

Appendix 3.8. SA Caseload and SA Rate for Singles, British Columbia, 1989-2010..................237

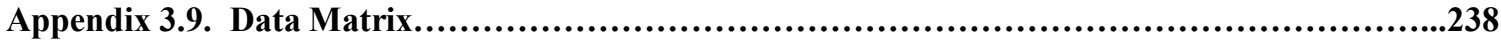

Appendix 3.10. Complete Regression Results (After Correcting for Heteroskedasticity).............242

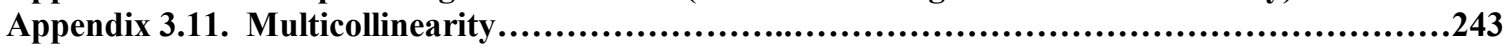




\section{List of Abbreviations}

$\begin{array}{ll}\text { AHCS } & \text { At Home/Chez Soi } \\ \text { CAP } & \text { Canada Assistance Plan } \\ \text { CCF } & \text { Cooperative Commonwealth Federation } \\ \text { CIHR } & \text { Canadian Institutes of Health Research } \\ \text { CMHC } & \text { Central Mortgage and Housing Corporation } \\ \text { DAU } & \text { Disability Adjudication Unit } \\ \text { DPA } & \text { Disabled Persons Act } \\ \text { EI } & \text { Employment Insurance } \\ \text { FBA } & \text { Family Benefits Act } \\ \text { GWA } & \text { General Welfare Act } \\ \text { HRDC } & \text { Human Resources Development Canada } \\ \text { IWA } & \text { Indian Welfare Agreement } \\ \text { MCSS } & \text { Ministry of Community and Social Services (Ontario) } \\ \text { NDP } & \text { New Democratic Party } \\ \text { NHA } & \text { National Housing Act } \\ \text { ODSP } & \text { Ontario Disability Support Program } \\ \text { OHC } & \text { Ontario Housing Corporation } \\ \text { OW } & \text { Ontario Works } \\ \text { PC } & \text { Progressive Conservative } \\ \text { PRWORA } & \text { Personal Responsibility and Work Opportunity Reconciliation Act } \\ \text { REB } & \text { Research Ethics Board } \\ \text { SA } & \text { Social Assistance } \\ \text { SHS } & \text { Survey of Household Spending (Statistics Canada) } \\ \text { SLID } & \text { Survey of Labour and Income Dynamics } \\ \text { TESS } & \text { Toronto Employment and Social Services } \\ \text { UI } & \text { Unemployment Insurance } \\ \end{array}$




\section{Introduction to Thesis}

"Ontario Works recipients without children experience the most significant depth of poverty among social assistance recipients..."

—Frances Lankin and Munir A. Sheikh, October $2012^{1}$

"There are no standards or methodology for determining the level of rates...There is also insufficient data collected on the needs and employability of, and outcomes for, people receiving social assistance."

—Frances Lankin and Munir A. Sheikh, June $2011^{2}$

Canada, like all industrialized countries, has experienced a move towards a new model of social policy in which many social programs-especially Employment Insurance (EI) and social assistance (SA) — are increasingly viewed as "costly, inefficient and ineffective" (Battle, 2001, p. 18). With the 1996 repeal of the Canada Assistance Plan (CAP), ${ }^{3}$ the provinces and territories retained social assistance programs; however, the federal government would no longer apply conditions and enforce those conditionsexcept the requirement that there be no residency requirement. There has since been a tightening of eligibility requirements and reduced benefit levels for both EI and SA in most Canadian provinces (Battle, Mendelson, \& Torjman, 2006). Indeed, between 1990 and 2004, the percentage of unemployed Canadians receiving EI benefits dropped from roughly 80 percent to 40 percent - a change brought about in part due to program redesign and in part due to labour market changes (MISWAA, 2006). Figure INT.1 serves as an illustration of this general phenomenon in the case of EI.

\footnotetext{
${ }^{1}$ Lankin \& Sheikh, 2012, p. 72.

${ }^{2}$ Lankin \& Sheikh, 2011, pp. 24 and 31.

${ }^{3}$ The CAP will be further discussed in Essay 1 of the present thesis.
} 
Figure INT.1. Unemployed Men and Women in Receipt of UI/EI Benefits

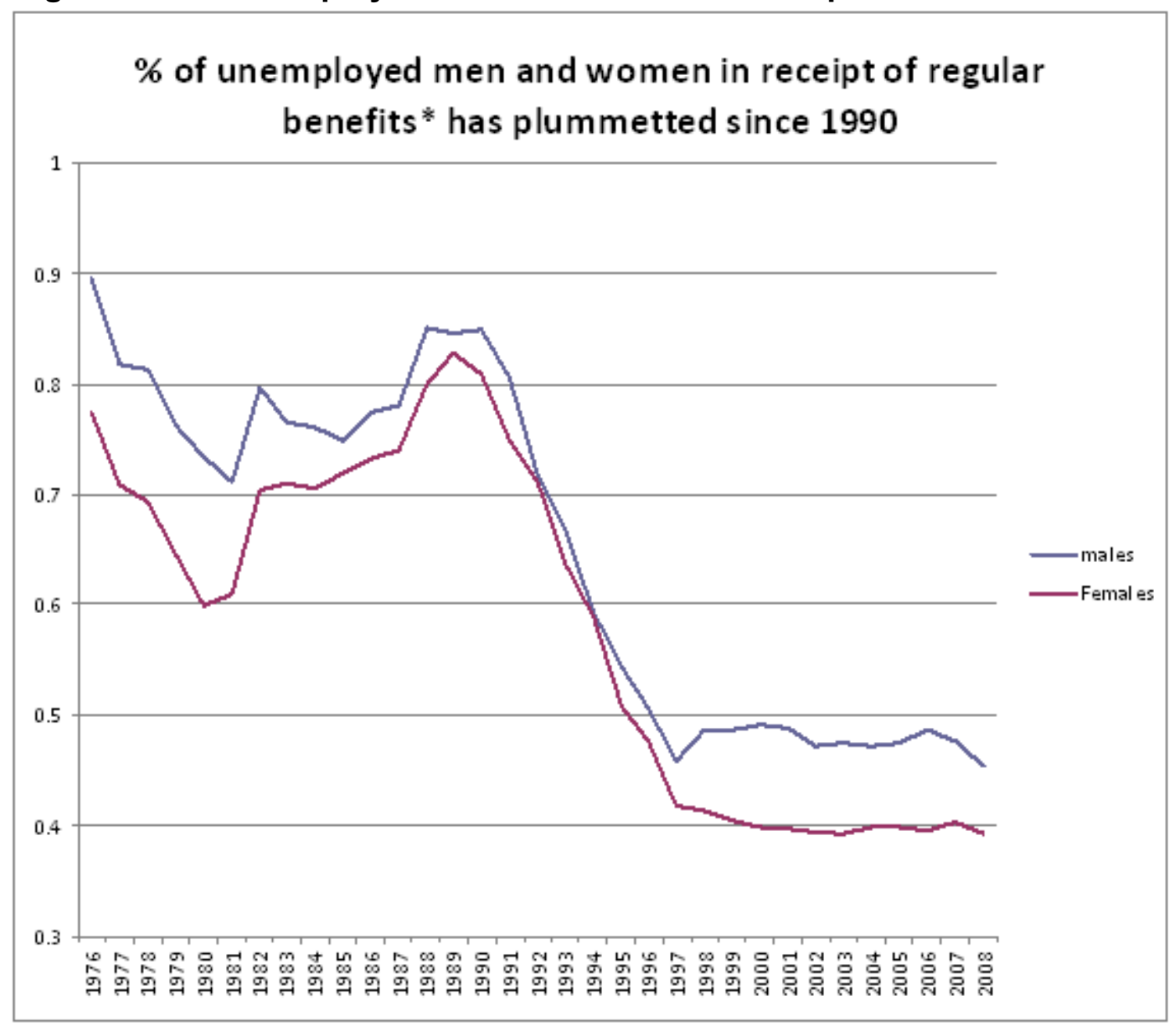

Source. Yalnizyan (2009).

Moreover, the number of total hours of work required for new entrants to be covered by EI increased from 300 hours to 910 hours; and the length of the benefit period for those who do qualify for EI was cut in half between 1989 and 1996 (Canadian Labour Congress, 2009).

It is worth briefly noting that singles (sometime referred to as one-person households) make up a growing percentage of Canadian households generally. Indeed, in 1941, they made up six percent of Canadian households; as of 2006, they comprised 27 
percent of Canadian households (Rea \& Samivel, 2014). Likewise, singles make up an increasing share of Canadian households in poverty (as defined by the Low-Income Cutoff). This is illustrated in Figure 3 below.

Though this dissertation will not probe precisely into what is driving singles to make up a larger share of low-income households, it is important to note that this phenomenon does appear to make it more important now than ever to understand socioeconomic trends affecting singles on social assistance.

In the mid-1990s, Ontario — along with Alberta and British Columbia_tightened eligibility requirements for the receipt of SA, a move that resulted in fewer people receiving basic welfare. Those individuals who continued to receive welfare across Canada often received lower benefit levels than previously: in 1995, benefit levels in Ontario - for those who remained eligible under the new system — were cut by 22 percent in one fell swoop (Kneebone \& White, 2009). The real value of SA benefit levels in Ontario then decreased each year, for the next seven years, as benefit levels were neither indexed to inflation nor adjusted periodically. It was not until 2004 that a new provincial government began making adjustments to SA benefit levels, on roughly an annual basis that approximated inflation.

Since 1998, Ontario's SA system has consisted of two programs: the Ontario Disability Support Program (ODSP) for persons "deemed to have a long-lasting disability preventing employment," and Ontario Works (OW) for those not deemed to be in that situation. Approximately 11 percent of OW recipients work while receiving benefits, but usually on a part-time basis (SARAC, 2010). 
Over the past two decades, total income received by singles has lagged behind that of other household types receiving SA. But this is not a story of the Ontario government increasing benefit levels for other household types on SA; rather, it is largely a story of both the provincial and federal governments increasing tax credits for households with children. Table INT.1 illustrates that singles on SA-more so than other household types on SA- experience economic marginalization at deeper levels than other household types on SA. This holds true whether one looks at SA benefit levels compared with the after-tax low-income measure, the after-tax low-income cut-off or the Market Basket Measure. Table INT.2, by contrast, illustrates the fact that this differential is not due to higher benefit levels received by other household types on SA; rather, it is due to tax credits received by SA households with children. 


\begin{tabular}{|c|c|c|c|c|}
\hline \multirow[t]{2}{*}{ Household } & \multirow[t]{2}{*}{ Total Income } & \multicolumn{3}{|c|}{ Percent of Common Poverty Measures for Toronto } \\
\hline & & $\begin{array}{l}\text { After Tax Low- } \\
\text { Income Measure }\end{array}$ & $\begin{array}{l}\text { After Tax Low- } \\
\text { Income Cut-Off }\end{array}$ & $\begin{array}{l}\text { Market Basket } \\
\text { Measure }\end{array}$ \\
\hline Single Adult & $\$ 7,878$ & $\begin{array}{l}(\$ 16,810) \\
47 \%\end{array}$ & $\begin{array}{l}(\$ 18,930) \\
42 \%\end{array}$ & $\begin{array}{l}(\$ 16,642) \\
47 \%\end{array}$ \\
\hline $\begin{array}{l}\text { Two-Adult } \\
\text { Couple }\end{array}$ & $\$ 13,669$ & $\begin{array}{l}(\$ 23,534) \\
58 \%\end{array}$ & $\begin{array}{l}(\$ 23,039) \\
60 \%\end{array}$ & $\begin{array}{l}(\$ 23,298) \\
57 \%\end{array}$ \\
\hline $\begin{array}{l}\text { Lone Parent, } \\
\text { One Child }\end{array}$ & $\$ 18,351$ & $\begin{array}{l}(\$ 23,534) \\
78 \%\end{array}$ & $\begin{array}{l}(\$ 23,039) \\
80 \%\end{array}$ & $\begin{array}{l}(\$ 28,298) \\
79 \%\end{array}$ \\
\hline $\begin{array}{l}\text { Lone Parent, } \\
\text { Two Children }\end{array}$ & $\$ 23,384$ & $\begin{array}{l}(\$ 28,578) \\
82 \%\end{array}$ & $\begin{array}{l}(\$ 28,688) \\
82 \%\end{array}$ & $\begin{array}{l}(\$ 28,292) \\
83 \%\end{array}$ \\
\hline $\begin{array}{l}\text { Two Adults, One } \\
\text { Child }\end{array}$ & $\$ 20,141$ & $\begin{array}{l}(\$ 28,578) \\
70 \%\end{array}$ & $\begin{array}{l}(\$ 28,688) \\
70 \%\end{array}$ & $\begin{array}{l}(\$ 28,292) \\
71 \%\end{array}$ \\
\hline
\end{tabular}

Source. Ontario Social Assistance Review Advisory Council. 2010.

\begin{tabular}{|l|c|c|c|c|c|c|}
\hline $\begin{array}{l}\text { Table INT.2. Tax Credits as a Percentage of Total Annual Income for Households on OW, } \\
2010\end{array}$ & $\begin{array}{l}\text { Social } \\
\text { Assistance }\end{array}$ & $\begin{array}{l}\text { Federal } \\
\text { Tax Credits }\end{array}$ & $\begin{array}{l}\text { Ontario } \\
\text { Tax } \\
\text { Credits }\end{array}$ & $\begin{array}{l}\text { Total Tax } \\
\text { Credits }\end{array}$ & $\begin{array}{l}\text { Total } \\
\text { Income }\end{array}$ & $\begin{array}{l}\text { Tax } \\
\text { Credits as } \\
\% \text { of Total } \\
\text { Income }\end{array}$ \\
\hline $\begin{array}{l}\text { Single } \\
\text { Adult }\end{array}$ & $\$ 7,020$ & $\$ 248$ & $\$ 595$ & $\$ 858^{\text {a }}$ & $\$ 7,863$ & $\mathbf{1 1 \%}$ \\
\hline $\begin{array}{l}\text { Two-Adult } \\
\text { Couple }\end{array}$ & $\$ 12,120$ & $\$ 496$ & $\$ 1,053$ & $\$ 1,549$ & $\$ 13,669$ & $11 \%$ \\
\hline $\begin{array}{l}\text { Lone } \\
\text { Parent, One } \\
\text { Child }\end{array}$ & $\$ 10,956$ & $\$ 5,242$ & $\$ 2,153$ & $\$ 7,395$ & $\$ 18,351$ & $40 \%$ \\
\hline $\begin{array}{l}\text { Lone } \\
\text { Parent, Two } \\
\text { Children }\end{array}$ & $\$ 11,532$ & $\$ 8,549$ & $\$ 3,303$ & $\$ 11,852$ & $\$ 23,384$ & $51 \%$ \\
\hline $\begin{array}{l}\text { Two Adults, } \\
\text { One Child }\end{array}$ & $\$ 12,696$ & $\$ 5,242$ & $\$ 2,203$ & $\$ 7,445$ & $\$ 20,141$ & $37 \%$ \\
\hline
\end{tabular}

Source. Ontario Social Assistance Review Advisory Council. 2010.

${ }^{a}$ The original source incorrectly states that this figure is $\$ 843$. 


\section{SA in Ontario}

Two of this dissertation's three essays focus exclusively on Ontario, where annual SA expenditures total approximately $\$ 8$ billion annually (Lankin \& Sheikh, 2012). As shown in Figure INT.2, singles without dependents are the fastest growing family type on SA in Ontario, and today make up almost 60 percent of the province's SA cases. Of these, almost two-thirds are men (Lankin \& Sheikh, 2011).

Figure INT.2. Ontario Works (OW) Caseloads in Ontario, by Family Type

\section{ONTARIO: OW Caseload by Family Type 1995-96 to 2010-11}

(Fiscal Year Average)

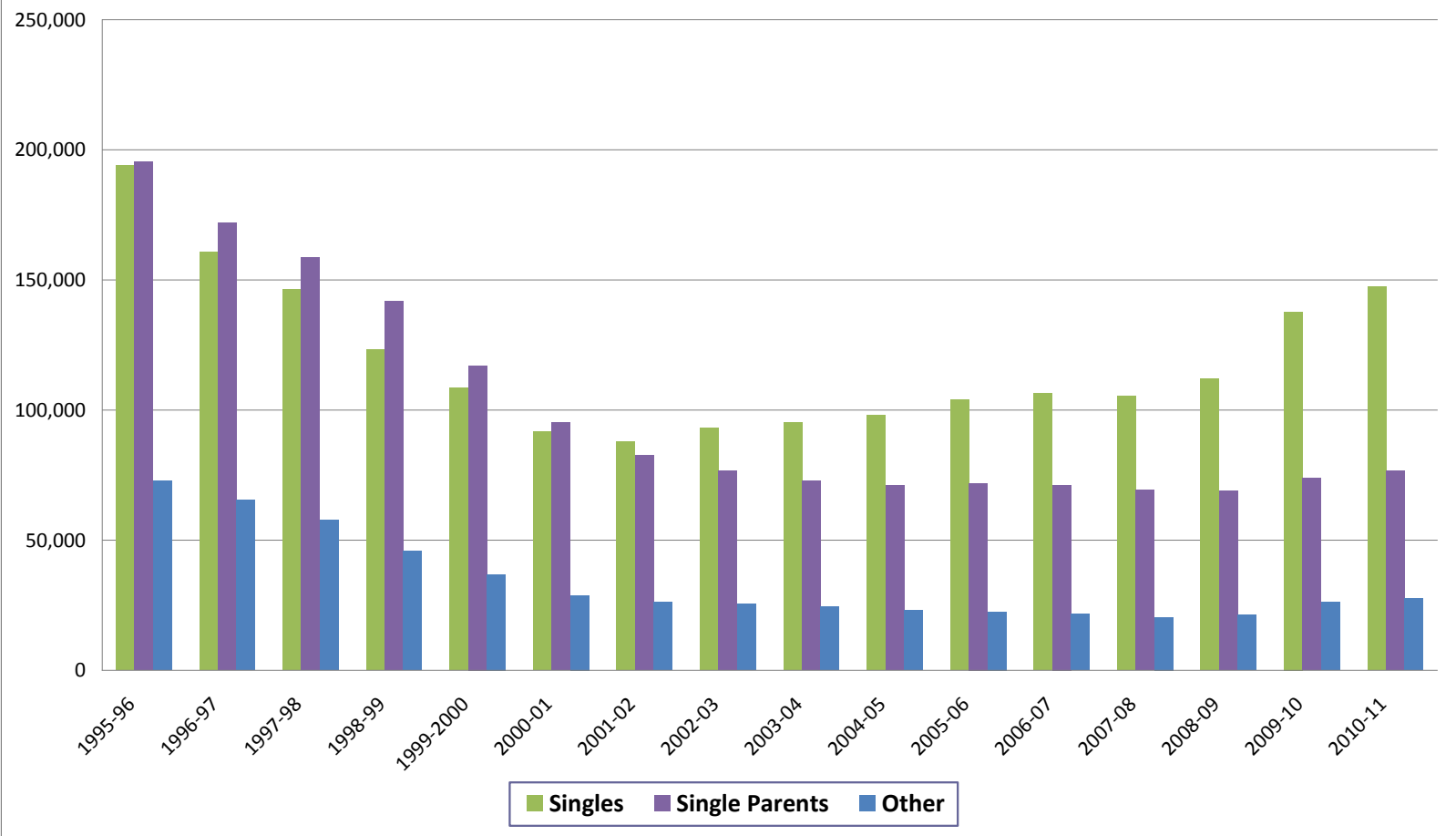

Source. Ontario Ministry of Community and Social Services.

As can be seen in Figure INT.3, Ontario has experienced a growing gap between what a single adult without dependents receives on SA versus what that same individual would receive working a full-time job at minimum wage. 
Figure INT.3. Annual Income from SA Versus Full-Time Employment at Minimum Wage, Ontario, 1967 to 2010.

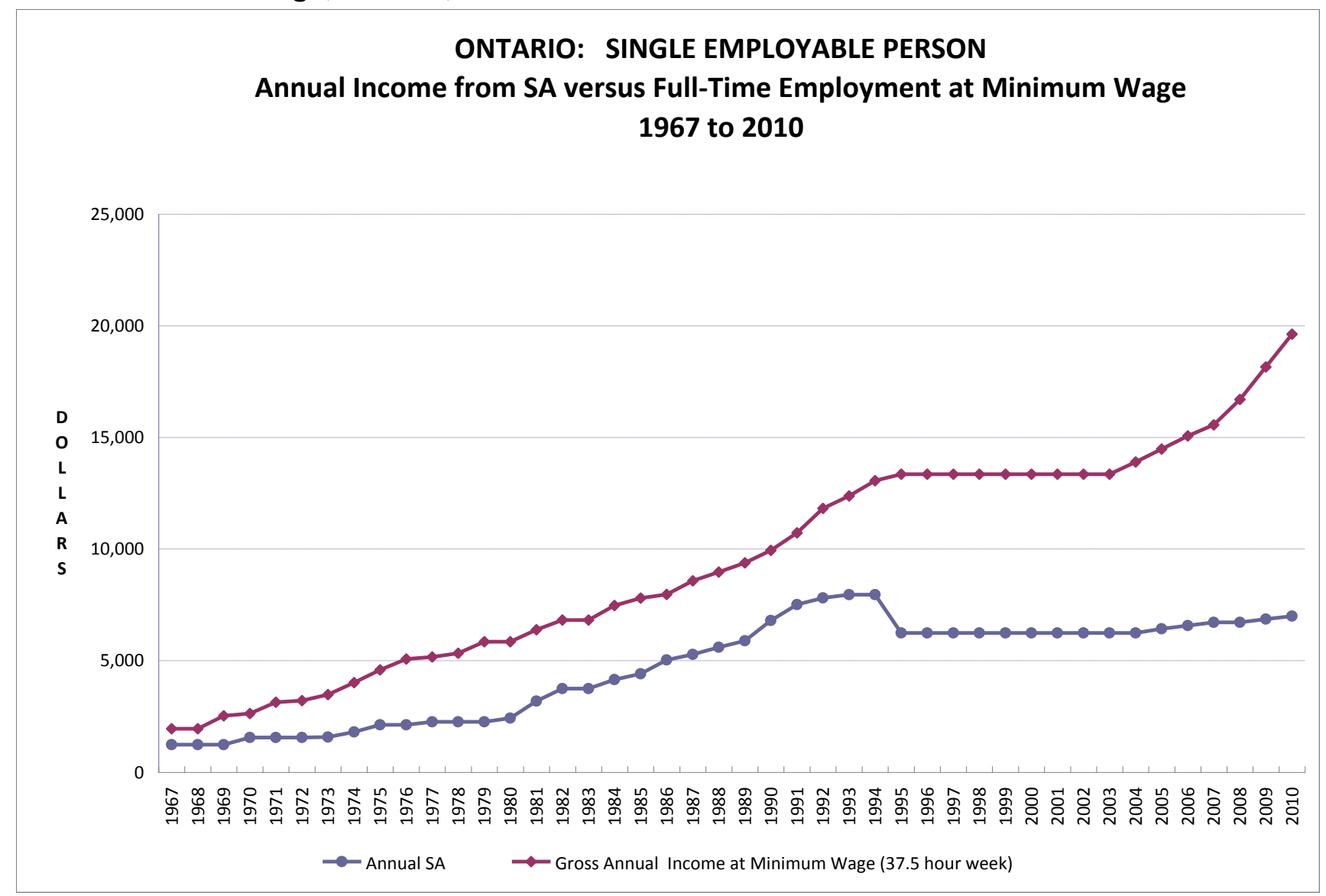

Source. Labour Canada and Ontario Ministry of Community and Social Services.

Calculations made by John Stapleton.

It is not clear how all singles are making ends meet while receiving very low benefit levels, as they gradually turn into Canada's 'forgotten poor.' To that end, this dissertation (especially Essay 2) seeks to offer more insight on a simple question that requires a nuanced answer. 


\section{The Three Essays}

The present document is a "three essay" dissertation on social assistance in Canada, with a focus on singles.

Essay 1. The first essay seeks to shed light on how Ontario's welfare system was developed, with a focus on the $1965-1975$ period. The essay will seek to analyze the evolution of the welfare system from the set of programs put in place in the post-World War II era, to a coordinated social assistance program in response to the CAP. The first section of the essay provides a theoretical framework, discussing the onset of capitalism, the plight of marginalised persons under capitalism, and the Poor Law system. It also examines the role of the modern state in the provision of programs for the poor including people with disabilities, single parents and people who are unemployed.

This will be followed by an overview of the far-reaching impact that World War II had on Canada's social welfare system as a prelude to the focus of the essay, which is on the development of Ontario's social assistance system between 1965 and 1975.

Essay 1 will help fill an important gap. Indeed, Guest (1997) looks at the history of social security very generally for all of Canada, while the focus of Boychuk (1998) is on social assistance for Canada as a whole. Haddow's work focuses on the development of the Canada Assistance Plan without discussion of what happened in any one province (Haddow, 1993). Other books and articles look at aspects of the evolution of Canadian social policy more generally during the same period (Blake, Keshen, Knowles \& Messamore, 2011; Finkel, 2006; Rice \& Prince, 2013). Last, Struthers (1994) has looked broadly at welfare in Ontario, but only until 1970. There is no single article or chapter that currently focuses on Ontario's welfare system for the 1965-1975 period. 
Essay 2. The second essay focuses on the monthly budgets of a small group of single men on SA residing in Toronto. It also looks at how some of these budgets change when income increases. It has five aims: 1) to document how very low-income single men spend their money each month; 2) to document the monies that are available, or not, for health and nutrition related expenditures; 3 ) to document the health status of very lowincome single men; 4) to examine the extent to which increases in income may influence monthly expenditures; and 5) to examine the extent to which increases in income may influence the health status of very low-income single men. In-depth, semi-structured interviews took place with 10 individuals over an 18-month period. Between four and six interviews with each individual took place, with each interview lasting approximately one hour. Interviewees were asked what they spend their money on each month. During this time, many of the interview subjects had made a transition from receiving OW to ODSP, representing a 78 percent increase in monthly benefit levels. They were also asked about health status.

A small body of research on budgets of very low-income households does exist, with Edin and Lein's (1997) having been considered ground-breaking at the time. But most research on budgets of very low-income households has been confined to households with children, and the vast majority of North American research on this topic has focused on the United States. No Canadian research on low-income budgeting has examined either what these budgets look like in the first place, or how these budgets change after a substantial increase in monthly income. Essay 2 therefore seeks to lay both the theoretical and methodological foundation for a larger study on the budgeting of SA recipients that the researcher hopes to undertake in the future. In effect, it is an 
exploratory study that has sought to demonstrate the feasibility of a larger study. It generates hypotheses that can hopefully be tested in a future study involving a larger sample size.

Essay 3. The third essay is a quantitative one, looking at the variation in provincial welfare caseloads over time and across six provinces. Least squares regression analysis was used, looking at the 1989-2010 period. Data on welfare benefit levels was obtained from the National Council of Welfare, and administrative data on welfare caseloads was collected from a variety of sources.

The analysis examines the relationship between last-resort SA caseloads and a variety of independent variables for the $1989-2010$ period. The essay provides a theoretical framework before assessing previous efforts at estimating the determinants of social assistance caseloads in Canada. This is followed by a data section that includes an analysis both of what steps were taken to find caseload data and why it is so difficult for researchers to obtain such information in Canada. Methods are then discussed, followed by results and a conclusion.

\section{Summary}

In broad terms, Essay 1 provides historical context, underlining the point that it was the passage of the Canada Assistance Plan by the federal government that led to the formation of a more developed social assistance program in Ontario during the 19651975 period. The result was a well-financed social assistance system involving cooperation from federal, provincial and municipal orders of government. Essays 2 and 3, taken together, represent parts of a cost-benefit analysis of an increase in SA benefits levels, looking at singles as a case study. Essay 3 examines the 'cost' represented in 
caseload increases across six Canadian provinces; Essay 2 looks at the 'benefits' of a 78percent increase in benefit levels, looking at a small subset of singles in Toronto. 


\section{Reference List}

25 in 5: Network for Poverty Reduction. (2010, February). Stepping up for Ontarians: Staying the course on poverty reduction commitments. Submission to Standing Committee on Finance \& Economic Affairs. Retrieved from http://25in5.ca/wpcontent/uploads/2010/01/25in5-budget-Submission-Jan-21-2010.pdf

Battle, K. (2001). Relentless incrementalism: Deconstructing and reconstructing Canadian income security policy. Retrieved from Caledon Institute of Social Policy website: http://www.caledoninst.org/pdf/894598873.pdf

Blake, R., Keshen, J., Knowles, N., \& Messamore, B. (2011). Narrating a nation: Canadian history post-confederation. Toronto: McGraw-Hill Ryerson.

Battle, K., Mendelson, M., \& Torjman, S. (2006). Towards a new architecture for Canada's adult benefits. Retrieved from Caledon Institute of Social Policy website: http://www.caledoninst.org/Publications/PDF/594ENG.pdf

Boychuk, G. W. (1998). Patchworks of purpose: The development of provincial social assistance regimes in Canada. Montreal: McGill-Queen's University Press.

Canadian Labour Congress. (2009). Left out in the Cold: The End of UI for Canadian Workers.

Canadian Press. (2010, July 22). 9 arrested at anti-poverty rally after Liberal party office occupied. The Globe and Mail. Retrieved from http://www.theglobeandmail.com

Edin, K., \& L. Lein. (1997). Making ends meet: How single mothers survive welfare and low-wage work. New York: Russell Sage.

Falvo, N. (2012, January 8). Ontario's poverty reduction strategy [Web log post]. Retrieved from http://www.progressive-economics.ca/2012/01/08/ontarios-povertyreduction-strategy/

Finkel, A. (2006). Social policy and practice in Canada: A history. Waterloo, ON: Wilfrid Laurier University Press.

Guest, D. (1997). The Emergence of social security in Canada (Third Edition). Vancouver: UBC Press.

Haddow, R. (1993). Poverty reform in Canada, 1958-1978: State and class influences on policy making. Montreal and Kingston: McGill-Queen's University Press. 
Kneebone, R. D., \& White, K. G. (2009). Fiscal retrenchment and social assistance in Canada. Canadian Public Policy - Analyse de Politiques, 35(1), 21-40. Retrieved from muse.jhu.edu/journals/canadian_public_policy/.../35.1.kneebone.pdf

Lankin, F., \& Sheikh, M. A. (2011). A discussion paper: Issues and ideas. Retrieved from the Commission for the Review of Social Assistance website: http://www.socialassistancereview.ca/

Lankin, F., \& Sheikh, M. A. (2012). Brighter prospects: Transforming social assistance in Ontario. Retrieved from the Commission for the Review of Social Assistance website: http://www.socialassistancereview.ca/

MISWAA. (2006). Time for a fair deal: Report of the task force on modernizing income security for working-age adults. Retrieved from St. Christopher House website: http://www.stchrishouse.org/

Ontario Social Assistance Review Advisory Council. (2010). Recommendations for an Ontario Income Security Review. Retrieved from http://www.mcss.gov.on.ca/documents/en/mcss/publications/social/sarac\%20report/S ARAC\%20Report\%20-\%20FINAL.pdf

Rea, W., \& Samivel, S. (2014). 2006 census housing series: Issue 21-the housing conditions of one-person households (Socio-economic Series 14-001). Retrieved from Canada Mortgage and Housing Corporation website: http://www.cmhc.ca/odpub/pdf/68009.pdf

Rice, J. J., \& Prince, M. J. (2013). Changing politics of Canadian social policy (2 ${ }^{\text {nd }}$ ed.). Toronto: University of Toronto Press.

SARAC. See Ontario Social Assistance Review Advisory Council.

Social Assistance Review Committee. (1987). A Reader on the History of Social Assistance in Ontario. Unpublished manuscript.

Struthers, J. (1994). The limits of affluence: Welfare in Ontario, 1920-1970. Toronto: University of Toronto Press.

Yalnizyan, A. (2009). Exposed: Revealing truths about Canada's recession. Retrieved from Canadian Centre for Policy Alternatives website: http://www.policyalternatives.ca 


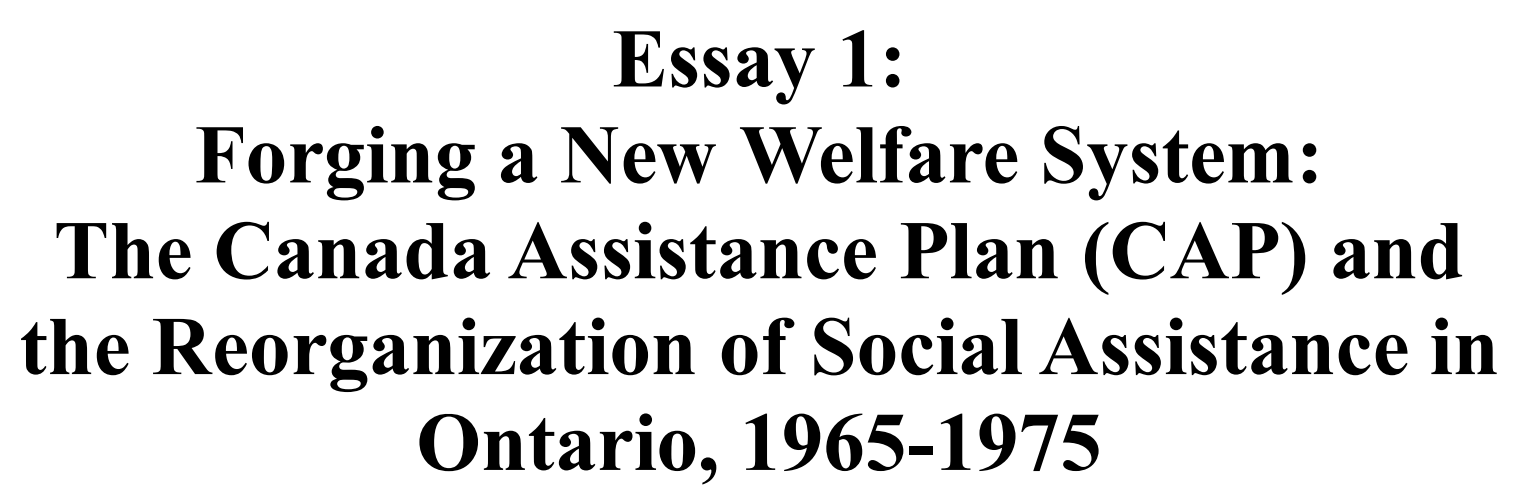




\section{Introduction}

Previous research on social assistance in Canada does not emphasize the development of Ontario's present-day system. Guest (1997) provides a useful, broad analysis of Canada's social welfare system, while the focus of Boychuk (1998) is on social assistance for all provinces. Analysis by Haddow (1993) is on the development of the Canada Assistance Plan; it does not focus on what happened in any particular province. Other research examines the evolution of Canadian social policy more generally during the same period (Finkel, 2006; Rice \& Prince, 2013), but not social assistance specifically. Last, Struthers (1994) has looked broadly at welfare in Ontario, but not beyond 1970. There is currently no one journal article or book chapter that focuses on the development of Ontario's welfare system during the 1965-1975 period.

With that in mind, the present essay aims to fill an important gap in the history of social assistance in Canada.

The present essay will focus on the development of Ontario's social assistance system from 1965 until 1975. Special attention will be paid to federal legislation brought into effect in 1966 that had far-reaching implications for social assistance recipients in Ontario. Time series data will be used to illustrate the implications that both federal and provincial legislative changes have had on spending on social assistance by multiple levels of government.

The first section of the essay provides a theoretical framework. It briefly discusses the onset of capitalism, the role of the state under capitalism, the plight of marginalised persons under capitalism, the emergence of "relief," the Poor Law system, and the principle of less eligibility. It also reviews the role of the modern state in the 
provision of programs for the poor including people with disabilities, single parents and people who are unemployed.

This will be followed by an overview of the profound impact of World War II on Canada's social welfare system. This event had important macroeconomic implications for Canada and resulted in the rapid development of what we now refer to as the "welfare state.'

The essay will analyze the development of Ontario's social assistance system between 1965 and 1975. This section will begin by discussing the economic and political context in both Canada as a whole, and also in Ontario. Why did the Canadian state in the form of the governments of Canada and Ontario create the resultant social assistance system? It will then analyze the emergence of the CAP and the far-reaching implications that this federal legislation had for the growth of social assistance in Ontario. 


\subsection{Theoretical Framework}

To understand the development of Ontario's social assistance system from the mid-1960s until the mid-1970s, it is important to use a theoretical framework that assists in explaining the events that occurred and why they occurred as they did. This was an ascendant period for Canada's welfare state. Like most western countries, the responsibility for the unemployed and for vulnerable persons had shifted to the state. No longer were such persons expected to seek handouts solely from family, charity or the church. Gradually, the state came to be seen as a central institution for helping those who had not fared well as wage earners.

Following an overview of theoretical concerns that will guide the rest of the essay, there will be a separate section looking at Ontario's relationship with the federal government in the early 1960 s as it pertained to social policy and administration — who was responsible for what, and how was this 'fiscal federalism' arrangement evolving? This will be followed by another section looking specifically at the policy that guided the administration of social assistance in Ontario from the mid-1960s until the mid-1970s. 


\subsubsection{Capitalism}

Capitalism entails the private ownership of most forms of production, and workers who work for wages (Naiman, 1997; Panitch, 1977; Stanford, 2008; Sweezy, 1970). In a simplified form, it involves two classes of people: capitalists, who own the means of production (i.e., land and machinery) and are often referred to as "the bourgeoisie" (Naiman, 1997, p. 89); and workers, who work for the owners of capital (Marx, 1976), and who are often referred to as "the proletariat" or "the working class" (Naiman, 1997, p. 89). Specifically, according to a Marxist approach:

- The capitalist does not seek to sell goods and then merely share profit (i.e., the difference between what a product sells for and what it cost to produce it) amongst workers. Rather, capitalists seek to pay workers as little as possible and then personally reap as great a share of profits as possible (Marx, 1976; Sweezy, 1970).

- The capitalist's share of profit is inversely related to that of workers (Marx, 1976).

- Technological advancement 'swings the pendulum' in favour of the capitalist. Such advancement usually reduces the amount of labour required to produce a good, thereby reducing workers' share of profit (Marx, 1976).

- There is an ongoing "struggle" (Marx, 1976, p. 58) between capitalists and workers. The former seek to reduce wages as low as possible and extend the work day as long as possible, while the latter seek to do the opposite (Marx, 1976). 
- It is important to capitalists that there be a substantial number of unemployed workers who eagerly search for work and are willing to accept jobs at low rates of pay. ${ }^{4}$ This reduces the power of current workers and keeps in check their demands for pay increases. Marx refers to this as a 'reserve army of labour.' Without this 'reserve army,' workers would feel emboldened to demand more pay (Piven \& Cloward, 1993; Sweezy, 1970).

- Government legislation (enforced by a judicial system) plays a crucial role in mediating this relationship (Marx, 1976; Sweezy, 1970); it can tip the balance in favour of one side or the other on such things as the length of the work day or the minimum wage rate.

\subsubsection{The Onset of Capitalism}

Before capitalism, people hunted, farmed, fished and gathered for subsistence. Many did so on land they did not own and in exchange for sharing most of their yield with landowners. Nevertheless, there was land to farm and animals to hunt (de Schweinitz, 1961; Stanford, 2008). For those workers who did not fare well in British society, there were guilds which "emphasized coöperative [sic] self-help..." (de Schweinitz, 1961, p. 15). Members of guilds not only helped each other, but also others - in this way, they performed a charity function. This involved the preparation of meals, the distribution of corn and barley on an annual basis and, for "destitute travelers," the provision of free shelter on a time-limited basis (de Schweinitz, 1961, p. 15). There were also private foundations that made it possible for wealthy individuals to leave

\footnotetext{
${ }^{4}$ Polanyi argues that capitalists desire that workers be hungry—quite literally—as this motivates them even more (Polanyi, 2001).
} 
bequests and "large gifts" (de Schweinitz, 1961, p. 15). Churches in England also raised funds for the poor. At one time, funds raised by churches "were divided: one-third for the maintenance of the church, one-third for the poor, and one-third for the priests" (de Schweinitz, 1961, p. 17).

In the $1700 \mathrm{~s}$, much of the western world transitioned to capitalism. Three phenomena led to this. First, there was new technology_-including the invention of large power-driven machinery and agricultural innovations - which increased productivity. Second, many European countries were trying to build empires, which meant they were forcefully extracting resources from colonies. Third, powerful national governments emerged in several western countries that: provided protection to private entities (Stanford, 2008); created national currencies that assisted trade both within countries and internationally; and assisted private entities in pushing people off their land when they were no longer required by landowners (de Schweinitz, 1961). This provided the conditions for the emergence of a new economic system that was comprised largely of 'winners' and 'losers.' Not every person's labour was needed in this new system-there was 'surplus labour.' For example, considerably less farm labour was required to feed the population (Brown \& Cook, 1974). Moreover, workers had virtually no legal rights to protest against the terms of this new arrangement. And this raised two important questions. First, if this new economic system did not have enough employment from which all individuals could draw predictable and ongoing wages, how were they to subsist? Second, if wage-less persons were to be assisted in surviving without land that they could farm, how were they to remain part of a healthy pool of reserve workers? 
This transition began in the eighteenth century and accelerated during the nineteenth century in the western world. As it took place, there was a considerable amount of "dislocation" (Polanyi, 2001, p. 42), ${ }^{5}$ as individuals throughout the western world were moved (or had to move) from rural areas to urban areas. ${ }^{6}$ Many also had to move from Europe to the Americas, Australia, New Zealand and other colonies (Hobsbawm, 2010). Previously, children had worked with their families on feudal estates; now, poor children were working in factories at very low rates of pay, often in very dangerous conditions. Meanwhile, western industrializing countries started to witness "the emergence of slums" in the larger urban centres (Polanyi, 2001, p. 42). Some individuals were strategically positioned so that they benefitted from this transition to capitalism — indeed, the living conditions for many improved (Polanyi, 2001); others found work, but under harsh conditions. In nineteenth-century Canada, for example, workers were often locked inside factories while they were working (Brown \& Cook, 1974; Canada, 1889; Guest, 1997; Kealey, 1973; Morton, 1999).

The state frequently intervened to induce workers to accept whatever conditions of employment were offered by owners of capital. For example, in sixteenth century England, workers "could not organize, they could not refuse work... and they could not move to new localities to find better working conditions." Further, "maximum wages" were stipulated by justices of the peace" (Piven \& Cloward, 1993, p. 37, emphasis in original). However, by the nineteenth century, trade unions were made legal in Britain,

\footnotetext{
${ }^{5}$ Between 1851 and 1901, Ontario's population doubled as Toronto's population increased sixfold (Guest).

${ }^{6}$ Comparable forms of dislocation continue to happen today-for example, when factories are relocated and when small farms are replaced by large-scale farming (Piven \& Cloward, 1993).
} 
France and Canada; yet, the state continued to place restrictions on their actions, including with the use of surveillance and police violence (Therborn, 1978).

As the western world was transitioning to capitalism, the state was not merely an innocent bystander. Rather, it generally 'picked a side,' and that side was typically the capitalist class over workers. The capitalist state functions largely in the interest of the capitalist class and by so doing it supports profit maximization by private interests and does not permit workers to stand in the way of that process. The state has often done this by using force, making it illegal for workers to assemble and organize into unions, not allowing strikes and protests, and not interfering with employers who lay off workers. That is, capitalism requires a steady supply of eager, desperate and cheap labour; the capitalist state, through legislation and a range of policies and programs, provides the tools to make this happen.

Panitch (1977) argues that, while the state actively sought to assist capitalists, it also tried to 'keep the peace,' preventing workers from becoming overly-disruptive and to some extent, keeping them healthy enough to work. Indeed, if the state was seen by workers to be acting too unequivocally in favour of capitalists, and if conditions were right, a major uprising could occur that would disrupt the capitalist system. Thus, it was essential that the state also provide a certain, basic level of social protection to workers. As capitalism evolved, individuals - especially those unable to secure waged labourneeded protection from this unfettered development and rapid expansion of market economies and the social dislocation that it created (Piven \& Cloward, 1993; Polanyi, 2001). 
"Relief" referred to assistance for those not earning sufficient wages (or not earning wages at all) to live on under capitalism, and it was typically offered with rigid conditions (Piven, 1999; de Schweinitz, 1961). ${ }^{7}$ In some countries, such relief was offered by non-state entities first and only later by the state. The English system was principally a public system, administered locally_in fact, until the nineteenth century, it was "largely independent of national authority" (de Schweinitz, 1961, p. 29; Polanyi, 2001). ${ }^{8}$ Sometimes the recipient had to work in exchange for the relief-in eighteenthcentury Europe, this work was typically done inside a workhouse. ${ }^{9}$ And there were usually residency requirements, whereby recipients had to be residing in a specific jurisdiction for an extended period of time before receiving relief - a restriction that further reinforced the notion that relief helped build a reserve army of labour and ultimately served capitalist interests (Piven \& Cloward, 1993). Sometimes it was given on condition that there be state oversight vis-à-vis the recipient's home life (Piven, 1999).

In the Poor Law Amendment Act of 1834, a sharp distinction was made between two groups: 1) the "physically helpless paupers whose place was in the workhouse;" and 2) "the unemployed" who were able to work and should therefore not be offered relief (Polanyi, 2001, p. 232). Indeed, outdoor relief would now be "forbidden to able-bodied

\footnotetext{
${ }^{7}$ By the early-twentieth century, in both Great Britain and the United States, relief was being referred to as "assistance" (de Schweinitz, 1961, p. vi).

${ }^{8}$ The French system, by contrast, was initially a private system, organized by church-based benevolent societies (Friedländer, 1962; Horne, 2002).

${ }^{9}$ When relief was provided in this context, it was known as "indoor relief." When it was provided outside of a workhouse and the recipient could live in their own home, it was referred to as "outdoor relief" (de Schweinitz, 1961, p. vi).
} 
men" (de Schweinitz, 1961, p. 132). ${ }^{10}$ The New Poor Law was therefore a mechanism that would further ensure that capitalists would have access to a desperate and docile pool of eager workers (Polanyi, 2001). One of its underlying principles was that hunger is effective at motivating workers - a hungry unemployed person would be more motivated to accept work at low pay and with poor working conditions, which is good for the capitalist. Conversely, 'too much relief' would have the opposite effect and therefore not serve the interests of capitalism (Polanyi, 2001).

The generosity of relief has varied across time and jurisdiction, often fluctuating according to local economic conditions; for example, it sometimes became more generous in times of economic depression, and less generous in times of economic growth (Piven \& Cloward, 1993). At certain points in history, relief was enhanced in response to large-scale displacement. This happened in England during the nineteenth century when "extremely cold" weather during the winter of 1860-1861 resulted in people applying for relief for the first time in their lives, raising increased awareness about conditions in workhouses, especially in London, and helping to bring on “dissatisfaction with the operation of the Poor Law..." (de Schweinitz, 1960, p. 140). As will be discussed below, this also happened in both the United States (Piven \& Cloward, 1993) and Canada (Guest, 1997) during the Great Depression. Great care was always taken to not be too generous with relief, in large part because 'too much relief' ran the risk of exerting upward pressure on wages (Piven, 1999). ${ }^{11}$ As the suffrage was extended,

\footnotetext{
${ }^{10}$ Outdoor relief returned to England in the 1930s (de Schweinitz, 1961).

${ }^{11}$ This fear is not unfounded. The theory that more generous income support program will exert upward pressure on wages is supported by a considerable amount of empirical research across 'modern day' welfare state regimes (Piven, 1999).
} 
the state became less limited in how restrictive it could be with relief. With the suffrage extended, many would-be recipients of relief were now voters (Piven \& Cloward, 1993). ${ }^{12}$

Through the nineteenth century and into the twentieth century, the principle of less eligibility "controlled the approach of English government to the relief of destitution." This practice held that relief could never make the person receiving it better off than a "paid labourer who was not in relief" (de Schweinitz, 1961, p. 124).

As will be further discussed below, these developments would have important implications for the early development of the administration of relief in Upper Canada (now Ontario). According to Irving (1989):

In 1836, Sir Francis Bond Head became lieutenant-governor of Upper Canada; before this he had been Assistant Poor Law Commissioner in Kent, England and he was determined to bring the principles and practice of 1834 to Upper Canada. Just before coming to Upper Canada, Bond Head had published an article in the Quarterly Review entitled "English Charity" in which he argued that the principle of "less eligibility should be strictly enforced, work houses should be made repulsive" and suggested that "if any would not work for relief, neither he should eat"...(Irving, 1989, p. 17).

\footnotetext{
${ }^{12}$ According to Esping-Andersen, theorists who believe in the ability of parliaments to "translat[e]...mobilized power into desired policies and reforms" subscribe to the class-mobilization thesis. These same theorists believe that robust social programs can empower workers and "strengthen labor movements" (Esping-Andersen, 1990, p. 16).
} 


\subsubsection{Protection from Capitalism in Canada}

In nineteenth-century Canada, some municipalities offered relief, as did some churches and charities (Finkel, 2006; Guest, 1997; Rice \& Prince, 2013). Usually, this relief came in the form of in-kind support, such as food, second-hand clothing and fuel. Unless the individual had a recognized disability, relief was often provided only after the recipient had been put through a means test. In Ontario, cash assistance was extremely rare until the introduction of the Ontario Workmen's Compensation Act in 1914- the first legislation in Canada to provide some funds to injured workers or their families. It was for "work-related sickness, disability, or death" (Guest, 1997, p. 40). ${ }^{13}$

Major international events had tremendously important implications for Canada's welfare state. Canada's entire 'war effort' for World War I required collective action that became palatable to many citizens — so palatable that it justified the introduction of a federal income tax that helped finance such initiatives as relief for disabled veterans, their widows and their orphan children. By 1920, several provinces (including Ontario) had brought in "financial assistance to needy mothers..." (Guest, 1997, p. 64); in the 1920s, the federal government introduced old age pensions (Guest, 1997; Rice \& Prince, 2013).

The Great Depression, much like the First World War, also helped pave the way for the further development of Canada's now embryonic welfare state. Indeed, the Great Depression made it clear to many that the private sector could not provide for all, making all people potentially vulnerable to unemployment. It also made it clear to many that the federal government had an important role to play in helping individuals when markets failed them (Guest, 1997).

\footnotetext{
${ }^{13}$ Some sectors —including farming — were not covered by this legislation (Guest, 1997).
} 


\subsubsection{Welfare and the Modern State}

According to class-based theory, workers suffer at the behest of capitalists. This is clearly reflected in the historical record. Owners of capital want to minimize what they pay to workers; yet, they want other workers to be available 'on demand.' Under capitalism, workers are commodities, to be drawn on and then discarded at the whim of capitalists' needs. In effect, workers have been a necessary but variable part of capitalism, which involves a constant struggle between capitalists and workers - a struggle that is mediated by the state, typically in favour of capitalists, and strongly affected by historical context. And when workers are without work, capitalists believe that they benefit from those workers receiving only as much assistance as is absolutely necessary so that there is an incentive for them to work when the private market requires their labour. This leads to the next focus of the present essay.

As alluded to above, many of the early administrators of Ontario’s social assistance system were strongly influenced by the (reformed) British Poor Law System (Finkel, 2006). Sometimes the influence came as a result of having been trained in England; in other cases, it came as a result of having attended conferences with British administrators (especially in the late-nineteenth century). Letter-writing with British administrators as well as study tours were also common (Jones \& Rutman, 1981; Rooke \& Schnell, 1987; Shackleton, 1988). The lasting influence of the British Poor Law System will therefore be an important consideration of the present essay. The British welfare system, born out of capitalism, helped forge Ontario's welfare system.

In the early part of the twentieth century, with the transition to capitalism well underway, the Canadian state was developing very quickly. Like the state in Western 
Europe, it would support the capitalist process — often with force. The state passed legislation that generally favoured capitalists and this legislation would be enforced by a judicial system that was also in support of the capitalist status quo. But in addition to supporting the accumulation function of capital, the capitalist state also tries to appease workers by providing a certain level of social protection. The level of generosity would vary across time, subject to major developments in the broader economic, political and social system.

As elaborated on above, in theory the capitalist state mediates between labour and capital, but it operates largely in the interests of capital. The essay will now turn to a consideration of the role of the Canadian state in the development and delivery of social assistance. Based on the theoretical discussion about the relationship between capitalists and workers and the role of the state in mediating these relationships, the following section of the essay applies some of these theoretical points to examine the development of social assistance. The following propositions are investigated in the present case study:

\section{Management of the market economy.}

High unemployment and relative destitution for many people during the Great Depression would lead to a profound change in thinking about the management of the Canadian economy. Prior to the Great Depression, it was common for citizens and elected officials to think of unemployment as an outcome of personal shortcomings; but by the end of the Great Depression, it would be much more common to view unemployment as a national problem requiring a strong state response. Further, after the Second World War, there would be a strong sense of national unity amongst Canadians, 
as well as a feeling that great things were possible if Canadians were united behind sensible public policy. What is more, with Canada emerging from World War II in a strong macroeconomic situation, there would be a palpable feeling among Canadians that senior orders of government now had the fiscal capacity to provide more generous levels of social protection.

\section{Surplus labour.}

Governments would be willing to expand social assistance programs in Canada to control surplus labour. It was for this reason as well that they would be willing to be more expansive in their approach. During the 1930s, Canadians witnessed considerable unrest among unemployed persons, including relief strikes and hunger marches; and during the 1940s, Canada saw an increase in labour unrest. Thus, by the early 1960s, it was clear that surplus labour had to be politically contained; otherwise, there would be demonstrations of various types that would cause the government of the day considerable embarrassment.

\section{Cooperation within the state.}

As part of this evolution, Canada would see increased cooperation among all major orders of government, as 'cost sharing' became the accepted way to fund social assistance (including for Indigenous persons living both on- and off-reserve). Against a backdrop of very strong economic growth, both elected officials and senior public servants felt that there was little need to be stingy about 'who pays' at every turn. In order to manage surplus labour, it was not worthwhile to bicker about which order of government was going to 'pick up the tab.' 


\section{Economic expansion and the capacity of the state to act.}

The new federalism would put the leadership role in the hands of Canada's federal government largely because it would be collecting substantially increased tax revenues. Private sector growth in the late-1940s, the 1950s and the 1960s would ultimately yield favourable outcomes for Canada's fiscal capacity. Indeed, federal revenue from corporate taxation and sales taxes would see massive growth during this period.

\section{The role of social democracy and organized labour.}

Organized labour in Canada would play a role in influencing these developments through the establishment of the New Democratic Party (NDP). In the 1960s, the NDP would not only hold the balance of power in two successive minority federal governments; it would also make major gains at the provincial level in Ontario. This would encourage senior orders of government to expand social protection for unemployed persons — including the expansion of social assistance coverage and increases in the generosity of social assistance benefits.

\section{Employable and unemployable.}

As Ontario's system of income assistance developed, expectations would vary as to which groups of people would be expected to search for and accept employmentthose expected to seek work were deemed 'employable,' and those who were not were viewed as 'unemployable.' To a large extent, this would influenced by macroeconomic context — when unemployment was high, the state would face mounting pressure to take a broader view of which groups of people were considered unemployable. 


\section{Changing attitudes to the poor.}

By the mid-1960s, the political and economic context would make it prudent for the government of Ontario to accept the terms of the Canada Assistance Plan, a new social policy framework introduced by the federal government. Not only was there now a growing sense that government could afford to do more for the unemployed; there was also a belief that government could not afford to ignore the need to provide more social protection for unemployed persons. The political will existed for government to do more; the fiscal capacity existed for more spending on the part of government; and pressure from organized labour made it difficult to not move in the direction of more social spending on the unemployed.

\section{Less eligibility.}

The principle of less eligibility, though not always referred to by name, would guide income assistance policy for unemployed persons throughout Canada (including in Ontario). Never would income assistance available to the unemployed come so close to wage levels that the unemployed would not feel incentivized to seek and accept employment. In adhering to this principle, the state would continue to serve capitalist interests. 


\subsection{The Evolution of a Strong State Role in Social Policy}

Major changes to social policy do not occur in a vacuum. Governments do not take on additional responsibilities without strong justification or incentive. Changes in social policy direction are heavily affected by macroeconomic changes, political changes, and changes to citizens' expectations. Indeed, major twists and turns in the direction, degree and depth of social protection measures for vulnerable persons in Canada took place in the first half of the twentieth century, and they are worthy of consideration below.

This section of the present essay will follow the trajectory of major changes to Canada's social protection measures, with a focus on the pre-1965 period, in order to provide background for the remainder of the essay. Based in the Marxist theoretical tradition, this analysis focuses on the relationship between labour and capital in a capitalist economy and particularly on the vulnerabilities of workers who are unable to work. The role that the capitalist state assumes under these conditions will also be explored, particularly the measures to provide a minimum income to people in need in Ontario. This trajectory will be laid out in chronological order, guiding the reader up to the 1965-1975 era.

The first part of the present section considers the pre-Depression era, a period during which the state had very little role in responding to social need. This is followed by a consideration of the profound effect of the Great Depression on social welfare policy throughout Canada - indeed, the deep unemployment caused by the Great Depression put considerable political pressure on governments to respond to social need and to eventually assume more of a legitimation function in Canadian society. This will be 
followed by a consideration of the equally profound impact of the Second World War, which left Canada in a strong macroeconomic situation that made it relatively easy for the state to continue to expand its reach in the realm of social welfare. The last section concludes. 


\subsubsection{The Impact of the Great Depression}

During the Great Depression, Canada's official unemployment rate surpassed 20 percent, a phenomenon that led to very visible manifestations of poverty (Drummond, 1987; Rice \& Prince, 2013). For example, according to Bacher and Hulchanski (1987), “in 1932 federal officials estimated that there were at least 70,000 'single homeless unemployed males' drifting about the country in search of work" (Bacher and Hulchanski, 1987, p. 152). In terms of policy and administration vis-à-vis social assistance, three issues were made clear during the Great Depression: 1) very high unemployment brings about labour militancy; 2) the Ontario government would have little choice but to take a stronger role in developing and implementing social welfare programs; and 3) provinces and municipalities by themselves could not fund social welfare-rather, federal assistance was required (Guest, 1997; Rice \& Prince, 2013).

Struthers (1991) notes: "[I]n the early years of the Depression most municipalities [still] did not provide any direct relief at all" (Struthers, 1991, p. 42). But this would change in short order. Indeed: "Out of 901 municipalities in the province, only 206 participated in provincial relief works and direct relief in 1930-1; 341 provided direct relief in 1931-2; and 550 in 1932-3, the worst year of the Depression" (Struthers, 1991, p. 42). Relief expenditure by the provincial government "between the years 1930-1 and $1931-2$ had jumped from $\$ 4,300,000$ to $\$ 13,500,000$ and the numbers on the dole had ballooned from 60,000 to 203,000” (Struthers, 1991, p. 46). By April 1933, 15.5 percent of Ontario's adult population was on relief (Stapleton, 2012).

As early as 1930, the federal government was providing some financial assistance to the provinces "for unemployment relief" (Guest, 1997, p. 87); it was that year that the 
federal government introduced payments to the provinces, voted on annually (Guest, 1997). In 1933, the federal government established camps for "physically fit homeless men" who were single (Grauer, 1939, p. 19); these individuals were considered by the state to be employable, and Marxist theorists would view them as members of a reserve army of labour. Administered by the federal Departments of Interior and National Defence respectively, the camps continued to operate until 1936 (Grauer, 1939; Rice \& Prince, 2013).

Faced with mounting unemployment in 1935, the federal government introduced legislation for a new unemployment insurance system with the passage of the Employment and Social Insurance Act in March of that year (Guest, 1997; Rice \& Prince, 2013). According to Guest: "The core of the act was a system of unemployment insurance...modelled on (or, more precisely, copied from) the British legislation of 1935. The act required compulsory coverage of all employees over the age of sixteen and earning less than $\$ 2,000$ per year” (Guest, 1997, pp. 88). However, in 1937, the Supreme Court of Canada and the Privy Council ruled that Canada's federal government lacked the constitutional authority to enact this legislation "on the grounds that it involved intrusion by the federal government into areas reserved for provincial legislation" (Guest, 1997, p. 105). In other words, a constitutional amendment would be necessary in order for the federal government to implement the measures in question (Guest, 1997; Rice \& Prince, 2013).

And so, in July 1940, with the approval of Canada's federal government - and with the support of all provinces except Alberta-Britain's Parliament amended Section 91 of the British North America Act to give Canada's federal government "exclusive 
jurisdiction over legislation in the field of unemployment insurance..." (Guest, 1997, p. 105). This made it possible for Canada's federal government to pass the Unemployment Insurance Act of 1940, which was very similar to the aforementioned Employment and Social Insurance Act of 1935. With the 1940 legislation, "the federal government's contribution was to be one-fifth of the total aggregate employer-employee contribution, plus all administrative expenses..." (Guest, 1997, p. 106). Moreover, the legislation aimed to cover three-quarters of Canada's wage earners. ${ }^{14}$ According to Guest, the officials who designed the plan wanted benefit levels to be "well below the wage earner's normal take-home pay to maintain incentives to re-join the labour force at the first opportunity. Thus, the benefit scales provided approximately one-half of the wage rate..." (Guest, 1997, p. 107). This development is consistent with Marxist theory-the state intervened in a way that provided minimal protection to workers, still providing very strong incentive for them to search for and accept employment at the earliest opportunity. Even as the state was providing benefits to the unemployed, it was doing so in the interest of capitalists.

In 1936, "the newly elected Liberal administration of Mackenzie King...boosted federal relief payments to the provinces by 75 per cent" (Struthers, 1994, p. 95). Between 1926 and 1939, federal government spending on "public welfare" (in constant dollars) increased fourfold (Guest, 1997).

Across Ontario, between 1927 and 1931, municipal direct relief expenditures, measured in nominal dollars, increased more than tenfold (Cassidy, 1932). Municipalities paid approximately 60 percent of this direct relief, while the Ontario

\footnotetext{
${ }^{14}$ However, the new program covered just two-thirds of Ontario's labour force (Struthers, 1994).
} 
government paid the remaining amount. Cassidy, writing in 1932, notes: "Administrative procedure has varied a great deal from place to place. Each community has its own system of investigation, eligibility rules, residence rules, scale of relief, etc." (Cassidy, 1932, p. 214). In some cases, private non-profit agencies disbursed this money on behalf of municipalities (Cassidy, 1932; Struthers, 1991). These private entities also provided some funding of their own, but typically not as much as government (Cassidy, 1932). Most of the direct relief expenditures "for indigent persons" covered food and fuel allowances (Cassidy, 1932, p. 166); to a lesser extent, it paid for rent and clothing (Cassidy, 1932; Grauer, 1939). In the case of food, vouchers were typically distributed to recipients which could be exchanged at specified retail stores, and which were redeemable only for certain food items. Likewise, in the case of fuel, recipients could redeem vouchers with a fuel merchant (Cassidy, 1932). Usually "able-bodied men" had to work in exchange for the relief (Cassidy, 1932, p. 176). The state appeared to be making an effort to manage the unemployed - keeping them alive, preventing political protest, and ensuring that a person always knew that they were better off having employment than they were relying on state assistance.

In 1932, the Ontario government formed the Advisory Committee on Direct Relief, chaired by Wallace Campbell, who was general manager of the Ford Motor Company of Canada. In addition to Mr. Campbell, the committee consisted of six businessmen (a clear nod to the interests of capitalists), along with one person (D.B. Harkness) "from the social welfare community" (Struthers, 1991, p. 48). One month after being struck, the Campbell Committee released a 24-page report which soon came to be viewed as "a landmark in Ontario social policy" (Struthers, 1991, p. 48). The report 
recommended that the Ontario government develop "provincial standards and uniformity in relief administration" (Struthers, 1994, p. 82). This included the development of a “framework for a provincial welfare bureaucracy" (Struthers, 1994, p. 87). ${ }^{15}$ Further, "the standards it recommended for food, shelter, and clothing became the benchmark for social assistance rates across Ontario until 1944" (Struthers, 1991, p. 48). But "[t]he standards it called for...were maximum ceilings, not minimum floors on municipal welfare expenditure" (Struthers, 1991, p. 49). It also recommended that there be no cash relief at all (Struthers, 1991). Put differently, the state showed very little interest in serving the interests of workers; it showed little regard for ensuring that those without work were made comfortable or received sufficient resources to purchase what they needed. Rather, the state was ensuring that the unemployed were not receiving too much; and in this way, the state appeared to make a concerted effort to serve in the interests of capital. The reserve army of labour would be controlled; but its members remained very eager to seek employment.

Of the \$713 million in relief disbursed across Canada between 1931 and 1937, almost half was paid by the provinces, roughly one-third by the federal government and one-fifth by municipalities (Grauer, 1939). Appendices A and B of the present essay provide detailed information on relief disbursements during the 1931-1937 period. By the mid-1930s, the Ontario government's share of relief payments represented more than half of the Ontario budget (Williams, 1984). In August 1935, the federal government announced that, rather than contributing one-third of relief costs, it would issue "flat

\footnotetext{
${ }^{15}$ In 1936, the provincial government transferred the administration of relief back to municipalities (Struthers, 1994).
} 
grants" that would amount to less money on an annual basis than previously (Williams, 1984, p. 21).

In 1935, the Ontario government passed the Unemployment Relief Act. With it, "for the first time the...claim of municipal responsibility for basic welfare was grounded in law [declaring that]...[e]very municipality shall provide relief for unemployed persons and their dependents" (Williams, 1984, p. 22). In an effort to contain relief costs, the Ontario government also "took over direct control of relief administration" (Struthers, 1991, p. 59) in 32 bankrupt communities "where the province was paying the total cost of the dole" (Struthers, 1991, p. 57). According to Struthers:

Over the winter of 1935 a field staff of 140 administrators was sent out to manage the dole in supervised municipalities and townships where the welfare department was convinced relief was excessive. All the elements of administrative reform developed in Toronto and Hamilton were implemented by Queen's Park officials, including systematic home investigation to detect undisclosed assets and income, work requirements for relief, detailed case files on families, and rigid adherence to Campbell Report maxima (Struthers, 1991, p. 59).

This led to "an explosion of unrest by the unemployed..." (Struthers, 1991, p. 59). Indeed, many unemployed persons were unhappy both with low levels of relief and the type of work required in exchange for that relief. As a result, "relief strikes" took place in several Ontario municipalities that same year (Struthers, 1994, p. 93). Likewise, in East York in November of that year, “2700 families, led by Workers' Association leader Arthur Williams," took part in a similar strike (Struthers, 1994, p. 94). Throughout Ontario, "raucous demonstrations" often took place at meetings of municipal councils, and "hunger marches" took place at Queen's Park; many of these events received considerable media attention (Struthers, 1994, p. 94). 
Perhaps ironically, these protests led to a "backlash" against the recipients of relief (Struthers, 1991, p. 59), and this prompted the provincial government to 'hand back' relief administration to the municipalities in question. It also prompted Queen's Park to lay off "the 140 investigators and twenty-four accountants hired to administer the dole in supervised municipalities..." (Struthers, 1991, p. 60). Finally, it led the Ontario government to provide lump-sum payments to each municipality, rather than fund a percentage of contributions (Struthers, 1991).

By 1937, the state mechanism for handling relief had developed. The provincial government "had developed the capacity to regulate, audit, investigate, and inspect municipal relief administration..." (Struthers, 1991, p. 64), and this had important political ramifications. Whereas previously "an unemployed movement had flourished in communities where the percentage and concentration of families on the dole was large" (Struthers, 1991, p. 64) —a movement that resulted in substantial increases in relief allowances - now any protest movement would have to exert political pressure at the provincial level, which would prove considerably more challenging (Struthers, 1991, p. 64).

By the end of the 1930s, it became commonly accepted that unemployment was a national issue, and that unemployment insurance would be most appropriately administered by the federal government. According to Grauer (1939):

Unemployment is a nation-wide problem demanding nation-wide coverage; there would be no point in duplicating machinery for nine provincial systems and nine provincial funds; and such an organization would interfere with the mobility of labour (Grauer, 1939, p. 67). 
Effectively, the federal government needed to play a role in managing surplus

labour. As of 1939, unemployment relief in Ontario was administered by the Minister of Public Welfare. Grauer (1939) provides elaboration:

For administrative purposes, the Province is divided into two areas, northern and southern Ontario, each of which is subdivided into districts served by provincial inspectors. Each municipality, however, has control over the details of its own relief administration. The Minister requires regular statements of relief expenditures and he has power to order an audit of the books, accounts and vouchers of any municipality relating to relief (Grauer, 1939, p. 83).

\subsubsection{The Impact of World War II}

Labour market conditions improved in Canada during the Second World War (Guest, 1997), and this had a very direct impact on relief. At the outbreak of the war in 1939, 10 percent of Ontario's adult population had been in receipt of relief. Just two years later, that figure had dropped to a mere two percent (Struthers, 1991; 1994). And by the end of the war in 1945, relief caseloads in Ontario were "almost negligible" (Struthers, 1994, p. 129). This process was accelerated "by provincial orders-in-council in the summer of 1940 which simply cut off funding for employable single men and married men on relief under the age of forty-five with up to two dependents" (Struthers, 1991, p. 73). ${ }^{16}$ Consistent with one of the present essay's propositions, the definition of 'employable' effectively changed in response to the rate of unemployment. What is more, with so few people on relief, one internal Ontario government memorandum stated that "there was 'no longer any justifiable argument that the relief schedule should not be on an adequate minimum total maintenance basis' for this group" (Struthers, 1991, p. 73).

\footnotetext{
16 These provisions remained in place until December 1957 (Swadron, 1972).
} 
As Canada's labour market improved, worker expectations (and demands) rose, and there was "mounting agitation" among returning soldiers who arrived back to Canada without housing (Brushett, 2007, p. 379). During World War II, the number of unionized workers in Canada doubled (Campbell, 1987; Guest, 1997; Historical Statistics of Canada, Series E175-177). This did not happen by accident; according to Campbell (1987):

Unionization was accelerated as a result of order-in-council P.C. 1003, which encouraged the spread of collective bargaining. It provided the right to union representation and collective bargaining to a wide section of the labour force, while providing for compulsory negotiations, conciliation and arbitration (Campbell, 1987, p. 22).

In effect, the state intervened more on the side of workers than capital for a period of time. This led to even greater demands by workers, much to the displeasure of employers. In 1943, the number of workers in Canada who were involved that year in a strike or a lockout was 10 times greater than just five years previously (Historical Statistics of Canada, Series E190-197).

Successes gained by workers led to greater popularity for the Co-operative Commonwealth Federation (CCF), and then its successor, the New Democratic Party (NDP) (Campbell, 1987). Campbell argues: "This growing and militant force became aligned with the CCF during the war. In 1943, the Canadian Congress of Labour endorsed the CCF as the political arm of organized labour" (Campbell, 1987, p. 22). Haddow (1993) further notes: "Support for the CCF surged during 1943 and 1944..." (Haddow, 1993, p. 21); the party had won the 1944 Saskatchewan election by a landslide 
(Finkel, 2006), becoming the official opposition in Ontario, and "placed first in a national public opinion poll" (Haddow, 1993, p. 21). ${ }^{17}$

In response to these developments, federal spending increased very substantially. As Campbell (1987) notes: "Federal government expenditures on goods and services rose from $3.4 \%$ of GNP in 1939 to $37 \%$ in 1944 , while the federal bureaucracy more than doubled in size from 46,306 to 115,908 employees" (Campbell, 1987, p. 24). He further notes that "the admirable results of the wartime planning experience had legitimized the idea of economic planning and an increased role for the state in the economy" (Campbell, 1987, p. 25). Finally, by the end of the war, "[u]nemployment was all but eliminated..." (Campbell, 1987, p. 26).

By the end of the World War II, the Conservative Party - threatened by the rise of the $\mathrm{CCF}$ - had 'transformed' itself into the newly-named Progressive Conservative Party. The PC party's new platform included "programmes to create jobs, a commitment to rising incomes and low-cost housing, social security, pensions, extension of education, and so forth" (Campbell, 1987, p. 27). The Liberal Party of Canada also transformed itself. According to Campbell (1987):

The 1943 Throne Speech saw the Liberal government commit itself to post-war planning for full employment and economic and social security. In the 1945 Throne Speech the government committed itself to providing employment for those willing and able to work. All of this suggested that the Liberal government was prepared to go far deeper into economic and policy waters than in the past" (Campbell, 1987, p. 28).

Although Marxist theorists argue that the state usually acts in favour of capitalists, they also argue that this varies depending on political context. In the case of Canada at

\footnotetext{
${ }^{17}$ Admittedly, support for the CCF both nationally and in Ontario had waned by 1945 (Finkel, 2006).
} 
the end of the Second World War, political and economic factors were clearly inducing mainstream political parties to shift their support on to the side of workers. Factors contributing to this shift (and all related to World War II) included a greater sense of collective strength among Canadians, reduced unemployment and the growing strength of organized labour. The federal government's approach to macroeconomic planning over the ensuing years — certainly until 1949— has often been referred to as Keynesianism. Initially, it was outlined by the Liberal government in 1945 in both the White Paper on Employment and Income, and the Green Book proposals; the former submitted to the House of Commons, the latter presented to the Dominion-Provincial Conference on Reconstruction (Campbell, 1987). The White Paper's proposals-presented to the House of Commons in April 1945-had "for their object the maintenance of levels of employment and income greatly above those ruling before the war" (Department of Reconstruction, 1945, p. 21). The White Paper further noted that such employment and income levels will require "government expenditures and revenues at higher than pre-war levels" (Department of Reconstruction, 1945, p. 21). Further, it noted that the federal government views "the post-war debt problem to be quite manageable" (Department of Reconstruction, 1945, p. 21).

The federal government's Green Book proposals, building on the White Paper, were released four months later. In the Green Book, the federal government explicitly stated its intent "to prevent recurrence of the kind of situation which existed in the thirties" (Canada, 1945, p. 51). In the Green Book's proposals, it assumed "a broad federal responsibility...for establishing the general conditions and framework for high employment and income policies, and for support of national minimum standards of 
social services" (Canada, 1945, p. 8). It further proposed that, "[a]s rapidly as possible the Unemployment Insurance Act will be widened to embrace all employed persons" (Canada, 1945, p. 43). The Green Book also asserted that a key

...requirement of post-war financial arrangements is that they should make possible at least an adequate minimum standard of services in all provinces while not denying to any province the advantages which its resources give to it nor the freedom to establish its own standards (Canada, 1945, p. 48).

According to Campbell:

The overriding objectives of the post-war Keynesian project in Canada were the maintenance of economic stability and of high levels of employment. Even after the war had virtually eliminated unemployment, the image of the Depression held the imagination of political groups, advisors and the government. They were all obsessively concerned with the prevention of unemployment, which had become simply unacceptable politically (Campbell, 1987, p. 39). ${ }^{18}$

These phenomena helped set the stage for what many political scientists have called 'cooperative federalism,' a term referring to the roughly two decades following World War II during which time federal and provincial officials in Canada collaborated on program development more than previously (and more than would be the case in ensuing years). This came in rather sharp contrast to previous chapters in intergovernmental relations in Canada, which had been dominated by the federal government. Cost-sharing between orders of government was very common over these two decades, with the provincial government often administering the jointly-financed programs. Such collaboration was especially strong in the 1960s, and the Canada Assistance Plan (to be discussed below) is viewed as a major product of this period of heightened cooperation (Dyck, 1976; 1995; Stevenson, 1999; 2004).

\footnotetext{
${ }^{18}$ Campbell argues that, though Keynesianism was "influential" during the 1945-1975 period, "it was never fully applied and played a less important role than other types of policy" (Campbell, 1987, p. 190).
} 
While there had been virtually no government-funded housing in Canada prior to the Second World War, almost 48,000 units of "wartime" housing_for civilians engaged in the 'war effort' (i.e., wartime industries) — were created between 1938 and 1947 (Rose, 1980). In 1944, Canada passed its second National Housing Act, this one more comprehensive than its precursor. A major goal of this legislation was 'economic stimulus,' as the Second World War was coming to an end and the federal government wanted to avoid the kind of post-war depression that was experienced after the First World War.

In 1945, the federal government passed the Central Mortgage and Housing Corporation $(C M H C)$ Act, creating a crown corporation that would administer the National Housing Act. CMHC would have a president, vice-president and board of directors appointed by Canada's federal government. Further, in 1947, a new program called Veteran's Rental Housing was created with the goal of creating 10,000 new units of housing per year for returning veterans. It should be noted that none of the housing units being created during this time, by any the above programs, were directed at the lowest-third of income earners (Rose, 1980). Put differently, the federal government was not trying to respond to a social need as much as it was responding to political challenges brought on by Canada's involvement in World War II.

In 1944, Canada's federal government "moved unilaterally to introduce family allowance legislation..." (Struthers, 1994, p. 123). Approximately 90 percent of all Canadian children up to the age of 16 would be covered by this new program (Guest, 1997). These children would have been viewed as 'unemployable,' meaning that the 
state could provide them with benefits without undermining the principle of less eligibility.

In 1951, the federal government took another step towards helping 'unemployable' Canadians by passing the Blind Persons Act. The federal government subsequently established cost-sharing agreements with all provinces and territories for means-tested benefits for blind persons between the ages of 18 and 65 (Guest, 1997). Again, by providing benefits to persons with recognized disabilities, the state's actions in this case were not making employment seem less desirable from the perspective of surplus labour.

In the same year, two new pieces of legislation with great relevance for older Canadians were brought in by the federal government, each requiring a constitutional amendment: the Old Age Security Act brought in a universal pension system for Canadians over the age of 70 (Haddow, 1993); and the Old Age Assistance Act brought in a means-tested program that was to be administered by the provinces and whose costs would be equally shared between the provinces and the federal government (Guest, 1997). These are further examples of the state providing social benefits for persons generally deemed 'unemployable.' It was therefore unlikely that, with these initiatives, the federal government would be accused of undermining work incentive among the unemployed.

In 1954, the federal government passed the Disabled Persons Act (DPA), which would provide means-tested "benefits to the "totally and permanently disabled"" (Haddow, 1993, p. 22) persons between the ages of 18 and 65 (Guest, 1997). The federal government then entered cost-sharing agreements with the provinces and territories 
(Guest, 1997). According to Haddow (1993), both of the seniors programs introduced in 1951 along with the DPA "became known as the 'categorical' programs. They provided benefits to highly visible persons who, in liberal terms, were 'deserving' because they were not expected to work" (Haddow, 1993, p. 22). Both pieces of legislation together represented additional, incremental advances by the federal government with respect to the provision of care for needy persons; and in neither case could the federal government be accused of undermining work incentive for capitalism's reserve army of labour.

By 1955, with Canada's official unemployment rate reaching 7 percent (its highest point since the end of World War II), ${ }^{19}$ the federal government faced pressure to assist provinces in responding to joblessness (Rice \& Prince, 2013; Struthers, 1987). Phrased in Marxist terms, the context was changing such that it was politically expedient for the Canadian state to temporarily intervene more on the side of labour than previously. In 1956, the federal government passed the Unemployment Assistance Act, which entailed the federal government paying 50 percent of the costs of a needs-tested benefit to unemployed persons, with each provincial and territorial government determining benefit levels for their respective jurisdiction (Guest, 1997; Haddow, 1993; Struthers, 1987). Initially, the legislation stipulated that the federal government would only provide funding for unemployment relief if and when 0.45 percent of a province's population was receiving relief — and in light of this stipulation, Ontario, Quebec, Alberta and Nova Scotia initially refused to "participate in the scheme" (Struthers, 1987, p. 21). This would change two years later:

\footnotetext{
${ }^{19}$ See Appendix 1.3 .
} 
In 1958, when the new Conservative government of John Diefenbaker abolished the 0.45 percent threshold and placed the Act on a straight 50-50 cost-shared basis, all provinces except Quebec came under the legislation (Struthers, 1987, p. 21).

According to Haddow (1993), the 1956 legislation "was the most significant federal intervention in the assistance field during the 1950s" (Haddow, 1993, p. 23). More importantly for the purpose of the present essay, it was also "the first piece of permanent federal legislation to provide funding for social assistance” (Moscovitch, 1988, p. 271). However, for many observers, there were two drawbacks to the new arrangement. First, social assistance eligibility rules and benefit levels would continue to be left as a matter between provincial and local welfare officials - and this led to major discrepancies in levels of receipt across Canadian jurisdictions. Second-and not unrelated to the first drawback - the new framework had an "unintended consequence" (Struthers, 1987, p. 25.). Though it was directed at serving 'employable unemployed' persons, because the federal government was paying half of the cost, provinces now had a strong incentive to reclassify other groups of individuals (e.g., disabled persons and elderly persons) into this category (Struthers, 1987).

In 1958, to take advantage of the new federal legislation, the Ontario government passed the General Welfare Assistance Act, whose ostensible goal "was to provide for temporary distress and short-term need" (Irving, 1987, p. 26). According to Irving (1987), the legislation required that "unemployed employables...prove to the satisfaction of a local welfare administrator that they were doing everything that was reasonably possible to find employment” (Irving, 1987, p. 27). And in the process, provincial officials were indeed reclassifying individuals as 'employable' in order to receive additional federal funding (Struthers, 1987). 
In 1964, important amendments were made to the National Housing Act (NHA). CMHC would now be authorized to lend funds to local entities, including non-profit corporations owned by a province or municipality, as well as charitable organizations. Those funds could then be used to build or purchase low-cost rental housing (Rose, 1980). Moreover, prior to 1964 , there had been a 75:25 federal-provincial split on the financing of capital costs (i.e., building and land) for newly-built public housing (that is, housing exclusively for low-income tenants). Beginning in 1964, this would become a 90:10 split. Prior to 1964 , there had also been a 75:25 provincial-federal 'cost share' on operating costs (i.e., heat, light, maintenance, insurance) for government-assisted housing; this now became a 50:50 split, representing a very serious 'nod of the head' by the federal government to the provinces with respect to future builds (Falvo, 2007). It is noteworthy that the federal government signalled a desire to fund the creation of considerably more public housing units, especially given that public housing at the time was an unpopular area for government involvement (Rose, 1980). Again, economic and political context was such that the Canadian state was temporarily siding more with workers than had previously been the case.

Ontario was quick to take on an interventionist role in response to the NHA amendments, helping create more than 84,000 units of public housing between 1964 and 1975 - units that were initially owned and operated by Local Housing Authorities (ONPHA, Undated). According to Sewell (1994):

In May 1964, the same month the NHA amendments were approved, Ontario introduced and approved legislation to establish the Ontario Housing Corporation $(\mathrm{OHC})$ as its public housing arm. OHC immediately began an aggressive program of acquiring small buildings and municipally sponsored projects, and encouraging new construction (Sewell, 1994, p. 135). 
When the Pearson Liberals formed a government after the 1963 federal electionpromising "to return the economy to full employment" (Campbell, 1987, p. 143) opinion polls indicated that 70 percent of Canadians "wanted a national compulsory earnings-related pension" (Finkel, 2006, p. 160). And so, in 1965, both the Canada and Quebec Pension Plans were created — together, they covered 92 percent of Canada's labour force (Guest, 1997). Finkel (2006) argues that, for the Pearson government, the Canada Pension Plan "was part of a concerted program to eliminate poverty that was announced in the speech from the throne in 1965" (Finkel, 2006, p. 259). However, for at least two reasons, one could argue that the state's role here was in encouraging work and therefore in serving the interests of capital. First, benefit levels earned under this pension system were directly related to past employment; and second, individuals received the benefits only after they moved beyond prime working years. 


\subsubsection{Conclusion}

Before 1930, the Canadian state played virtually no role in providing benefits to unemployed persons. However, the magnitude of poverty and social dislocation of the Great Depression led to changes. The effects of mass unemployment sent a clear message to most Canadians that few people are immune to joblessness and that government should play a role in responding to unemployment and to the social problems that accompany it. Moreover, World War II raised citizens' expectations further, as Canadians saw the potential of their country to both provide and succeed on a collective basis. Both events, in succession, contributed to the transformation of systems of social protection in Canada as a whole, and Ontario specifically. Indeed, Canada's transition from having a weak system of social protection to a fast-growing one helped set the foundation and tone for the development of Ontario's social assistance system during the 1965-1975 period.

Several themes emerge from this section of the essay. First, in considering the period before the Great Depression, it appears that the state in a capitalist system is unlikely to provide assistance to unemployed workers if it is not pressure to do so by external forces. When Canada became a country, assistance for the needy was an afterthought at best. Those in power appeared content to govern on behalf of capitalists. Further, when it became clear that the federal government initially had no interest in this realm, provinces and municipalities involved themselves only reluctantly, and usually under duress.

A second theme is the centrality of the principle of less eligibility. Indeed, in Canada, whenever the state did intervene to provide assistance to those not well served 
by the private market and their families, the need for cheap labour by private enterprise was paramount. If a particular form of state aid for the needy was deemed to have the potential to undermine the supply of cheap labour to the private sector, it was typically regarded as a bad idea. Such aid would often only be provided if legislators could be assured that it would not interfere with labour supply.

A third theme is that the macroeconomic context can have a profound impact on levels and types of assistance provided to persons in need. When very high unemployment makes it clear to voters that unemployed persons are not necessarily to blame for their plight (as happened in Canada during the Great Depression), providing assistance to those without work is suddenly more palatable to both voters and to the state. Likewise, when labour market conditions become so favourable that the percentage of adults requiring relief becomes very low by historical standards (as happened in Canada as a result of World War II), elected officials may feel less stingy about the provision of relief to those in need. And herein lies a contradiction: Canadian history suggests that both high and low unemployment can lead to increased levels of social spending directed at needy persons. In the case of the former, government spends when it finds itself in a period of crisis; in the case of the latter, it spends when it finds itself in a period of surplus. Both scenarios can make it more politically acceptable to increase spending on the poor - in the first case because it is necessary, in the second case because it is possible. 


\subsection{Ontario's Welfare System: 1965-1975}

The period spanning 1965-1975 marked a period in which Ontario's welfare system underwent profound change. New federal legislation governing the disbursement of funding to provinces for social assistance and select social services would bring all Canadian provinces into a much more engaged relationship vis-à-vis funding for lowincome Canadians. During this period, the federal government was not acting in a political vacuum; nor was the Ontario government. Both economic and political changes help explain why the Canada Assistance Plan (CAP) was enacted, and why all provinces (including Ontario) agreed so quickly to its terms.

This section of the essay outlines the key economic and political factors at both the federal and provincial levels that help explain CAP's introduction. It also discusses CAP's components, as well as the implication the legislation had for the delivery of social assistance in Ontario_-including for Indigenous peoples living on reserves. Key provisions of the General Welfare Assistance Act (GWA) and the Family Benefits Act (FBA) will then be discussed, followed by a discussion of Ontario caseload trends (both for GWA and FBA) throughout the 10-year period on question. After outlining changes in annual expenditures related to social assistance at both the federal and provincial level, the chapter will close with a brief conclusion. 


\subsubsection{The Canada Assistance Plan}

In April 1965 - after more than a year of negotiations - the federal Liberal government announced the creation of the Canada Assistance Plan (CAP) in that year's throne speech (Haddow, 1993). An article appearing in The Toronto Daily Star the following day referred to the CAP as a plan to "aid needy people" (Toronto Daily Star, 1965, April 6). Later that week, a Globe and Mail article stated that, under the terms of the CAP, "the federal Government would increase substantially its contribution to welfare services" (Globe and Mail, 1965, April 9). The following day, the same publication stated that, in relation to existing federal-provincial agreements, CAP "is more generous... and it is expected that most provinces will decide to switch over to it as soon as possible" (Globe and Mail, 1965, April 10). Before month's end, the Globe and Mail noted: "The plan as outlined by Mr. Pearson would embrace all welfare matters and give maximum flexibility in granting of assistance [sic] to the provinces from the federal treasury" (Globe and Mail, 1965, April 20).

Judy LaMarsh, Canada's Health and Welfare Minister in 1965, noted in her autobiography that CAP was then accepted by provincial governments very quickly: "The Canada Assistance Plan was readily accepted by all the provinces. Only two meetings of ministers devoted to its details were held, and it was ready to go" (LaMarsh, 1968, p. 119). Indeed, the Globe and Mail headlines corroborate this account of events. A 9 April 1965 headline from the publication reads "LaMarsh Gives Welfare Plan to Provinces." And on 20 July 1965, the following headline appeared in the same paper: "Welfare Merger in Canada Assistance Plan Given Unanimous Endorsement by Premiers." The latter article noted that, under CAP, each recipient's need "will be 
determined by the provinces and may vary from province to province." It also noted that, whereas the federal government previously did not contribute to aid for "allowances to needy mothers and dependent children," this would change under CAP (Globe and Mail, 1965, July 20).

Clearly, there was a very high level of cooperation between the federal government and the provinces at this time. Some context will now be offered in order to provide the reader with a better understanding of what had led to this cooperation. This will include an effort to explain why Ontario accepted its terms so quickly.

\subsubsection{The Economic Background}

In the mid-1960s, Ontario's economy was in a very favourable position. Interviewed nearly three decades later, Ontario's chief CAP negotiator, Dorothea Crittendon, noted: "When all this was being negotiated in boom times after the Second World War, no province or the federal government ever expected to be in a deficit position. Everybody had money" (Stapleton \& Laframboise, 2007, p. 8). This may have made the Ontario government feel 'less stingy' in approaching CAP's terms — or, in Marxist terms, it likely made the state more inclined to temporarily serve the interests of workers. Indeed, Novick (1980), writing about Ontario social spending in the "postwar decades," argues: "Whenever new [social] problems were identified, or the capacity of the private sector was exhausted, government was persuaded to respond" (Novick, 1980, p. 384).

It is therefore worth providing some context with respect to Canada's macroeconomic situation at the end of World War II. The gross annual value of production in Canada's manufacturing sector increased by 125 percent (in real terms) 
between 1945 and 1965 (Historical Statistics of Canada, Series R1-22). The annual value of production of Canada's iron and steel sector increased by more than two-thirds (in real terms) between 1945 and 1958 (Historical Statistics of Canada, Series R354-359).

Between 1957 and 1965, the annual value of production in the metal fabricating industries in Canada increased by more than 65 percent (Historical Statistics of Canada, Series R360-370). In Canada's petroleum and coal products industries, annual production (in real terms) increased by almost 200 percent between 1945 and 1965 (Historical Statistics of Canada, Series R439-449).

Not surprisingly, this strong economic growth resulted in major improvements to the federal government's fiscal situation. Between 1945 and 1965, in real terms, annual federal revenue from corporate income taxes increased by more than 300 percent, while annual federal revenue from sales tax increased by almost 400 percent. During the same 20-year period, total federal tax revenue, in real terms, nearly doubled (Historical Statistics of Canada, Series H1-18).

Ontario’s economy also saw strong growth in the post-war period. Between 1958 and 1965, annual production in Ontario's manufacturing sector, in real terms, increased by more than 50 percent (Historical Statistics of Canada, Series R84-94). Between 1945 and 1949, the annual value of production in Ontario increased by 50 percent (Schull, 1978). Though Ontario experienced a recession in the late-1950s and early-1960s (White, 1985), the province's official unemployment rate did not rise above 5.5 percent at any point during this time frame - and by 1965, the province's official unemployment rate had dipped down to 2.5 percent (Historical Statistics of Canada, Series D491-497). ${ }^{20}$

\footnotetext{
${ }^{20}$ See Appendix 1.3 .
} 
Between 1945 and 1965, Ontario's annual revenue - total net general revenue, expressed in real terms - increased by more than 500 percent (Historical Statistics of Canada, Series H124-135). During the same time frame, provincial spending - total net general expenditure, expressed in real terms — increased by almost 600 percent (Historical Statistics of Canada, Series H197-208). Ontario’s civil service “doubled from about 7,500 employees at the end of the Second World War to some 15,000 employees in the early 1950s and then doubled again by 1960" (White, 1985, p. 275).

\subsubsection{The Political Background}

Lester B. Pearson, "an enthusiastic supporter of President Franklin Delano Roosevelt and the New Deal," became leader of the Liberal Party of Canada on January 16, 1958 (English, 2005, p. 7). According to English (2005): "Pearson began to develop new policies that would reflect the liberalism of [Quebec Premier Jean] Lesage and, to some extent, of John Fitzgerald Kennedy, who was to become president of the United States in January 1961" (English, 2005, p. 14). On April 22, 1963, Pearson became prime minister in a minority Liberal government; and in 1965, after yet another general election, the Liberals formed another minority government, still with Mr. Pearson as leader (English, 2005). English further notes: "Although social welfare was, constitutionally, a provincial responsibility, the Pearson governments legislated boldly in the field..." (English, 2005, p. 25).

By the mid-1960s, with concern about the growing popularity of the New Democratic Party, Pearson's Liberal minority government was 'moving to the left' (Bryden, 1997). Writing in the Toronto Daily Star about the 1965 federal throne speech, Peter C. Newman argued that the government's list of commitments "makes it clear that 
the Liberals have become concerned over the chances of an NDP surge. To meet this threat, they have moved Left along the spectrum of Canadian politics..." (Newman, 1965).

At Queen's Park, the Tories appeared to have a strong grip on power, winning consecutive majority governments beginning in 1955 - a string of which would not end until 1985. In his memoirs, CCF/NDP leader Donald C. MacDonald would write:

On the provincial scene, the big question since 1943 had been which opposition party would emerge as the alternative to the Tories. In 1943 the CCF had been official opposition, in 1945 the Liberals. In 1948 a resurgent CCF regained the position, in 1951 the Liberals again (MacDonald, 1998, p. 92).

By the mid-1960s, Ontario Premier John Robarts was emerging as a wellrespected political leader on the national scene. Decades later, his biographer wrote that on federal-provincial matters Robarts" "instinct was to favour a national solution rather than a limited provincial approach, or at least a national solution that would respect provincial rights" (McDougall, 1986, p. 162). What is more, during "major speeches in the spring of 1964 Robarts had urged an end to adversarial approaches to conflicts in federal-provincial jurisdiction” (McDougall, 1986, p. 162). Moreover, the Ontario NDP appeared to be making great strides at the expense of the Tories. In the 1967 provincial election, the NDP's “popular vote had jumped from 15 per cent to 26 per cent, with an increase in seats from eight to twenty. The Tories had slipped from 49 per cent to 42 per cent, with a loss of eight seats..." (MacDonald, 1998, p. 145). Ontario therefore had a premier who was seeking more cooperation among senior orders of government while also feeling pressure from a political party supported by organized labour.

In the above context, CAP became a relatively straightforward initiative for Ontario's Tory government to accept — but not without some sacrifice. Indeed, Ontario's 
chief CAP negotiator noted that "we gave up a lot in Ontario to ensure that people across Canada were to have equal opportunities for social assistance and care" (Stapleton \& Laframboise, 2007, p. 8). She continues:

I'll give you a perfect example of what Ontario gave up. We gave up residency requirements and we're an 'in' immigration province. We take in thousands of people a year from either other countries or other parts of the country, like the Maritimes and the Prairies. Where provinces had (secondary) migration to Ontario, many of those people arrived here and some were subsidized by those provinces when they arrived here and applied for welfare or applied for Ontario housing. We said, "Okay, we will not look at residency for the purposes of the Act and the distribution of social welfare across Canada. Canada is a country and residency rules do not apply. The only exception will be sponsored immigrants, in which case we expect the sponsor to be responsible for five years (Stapleton \& Laframboise, 2007, p. 10).

\subsubsection{The Framework of the Canada Assistance Plan}

The CAP would provide a federal "regulatory framework" (Moscovitch, 1996, p. 67) that would govern cost-sharing of social assistance and some social services across Canada. In July 1966, it became law, taking effect beginning in the 1967-1968 fiscal year (Moscovitch, 1988). From that point on, the federal government would pay 50 percent of the cost of social assistance and some social services delivered by provinces, territories, municipalities and community agencies, provided certain conditions were met (Moscovitch, 1988; 1996). Moreover, CAP "enabled federal sharing of costs in certain areas which were not previously shared under the Unemployment Assistance Act," including financial assistance to "mothers with dependent children" and "health care services to needy persons" (SPCMT \& OWC, 1977, p. 19). It also required the provinces to provide benefits to people with disabilities living in the province - and this resulted in considerably more Ontario households being eligible for provincial welfare. These changes are summarized in Table 1.1 . 
Table 1.1.

Implications of CAP on Direct Financial Assistance to Persons in Ontario

\begin{tabular}{ll}
\hline \multicolumn{1}{c}{ Program } & \multicolumn{1}{c}{ Implication } \\
- Bisability Allowances & $\begin{array}{l}\text { Province agrees to pay half the costs. } \\
\text { These are new costs to the province. }\end{array}$ \\
\hline - Unemployment Assistance & $\begin{array}{l}\text { Federal and provincial governments } \\
\text { continue to cost-share on } 50 / 50 \text { basis. }\end{array}$ \\
\hline - General Welfare Assistance & $\begin{array}{l}\text { Federal government agrees to pay half } \\
\text { the costs. These are new costs to the } \\
\text { federal government. }\end{array}$ \\
\hline
\end{tabular}

Though neither the CAP legislation nor provincial regulations pertaining to it were explicit about the matter, the legislation was thenceforth interpreted by social assistance administrators "to mean that social assistance applicants could not be required to accept employment as a condition of receipt of assistance" (Moscovitch, 1988, p. 274). Nor could a recipient be penalized "for not accepting employment" (Moscovitch, 1996, p. 70). That said, the legislation "did not restrict the provinces from requiring employable recipients to undertake a job search" (Moscovitch, 1996, p. 70). Put differently, recipients could be forced to look for work, but not be forced to accept work as a condition of receiving welfare. The fact that the Canadian state was now placing new restrictions on how much pressure could be put on a worker to accept employment 
suggests that, under CAP, the state was being more supportive of workers than had previously been the case.

The CAP placed limits on the amount of earned income a recipient of social assistance could make and under what conditions. The CAP's directorate also had rules governing asset limits of recipients (Moscovitch, 1996). Further, CAP stipulated that there could be no residency requirements for recipients; that is, a recipient could move from one province to another and still receive benefits in the new province without having to wait for an extended period (Moscovitch, 1988; 1996). ${ }^{21}$ As noted in the previous section, for Ontario - a frequent destination for Canadians in search of workthis was viewed as a major concession (Stapleton and Laframboise, 2007). CAP also required that each province and territory have an appeal process in the event that a recipient disagreed with a ruling made by an administrator (Moscovitch, 1988; 1996). Not having residency requirements and requiring that recipients had the right to an appeal process are further indications that, with CAP, the Canadian state was being more partial to workers. But there were limits to how much the state would favour workers, even under CAP. For example, CAP did not stipulate what benefit levels must be for each recipient household; this was left up to each province and territory (Moscovitch, 1988).

\footnotetext{
${ }^{21}$ An important exception to the residency requirement was the case of sponsored immigrants, in which case the sponsor was "responsible for five years" (Stapleton \& Laframboise, 2007, p. 10).
} 


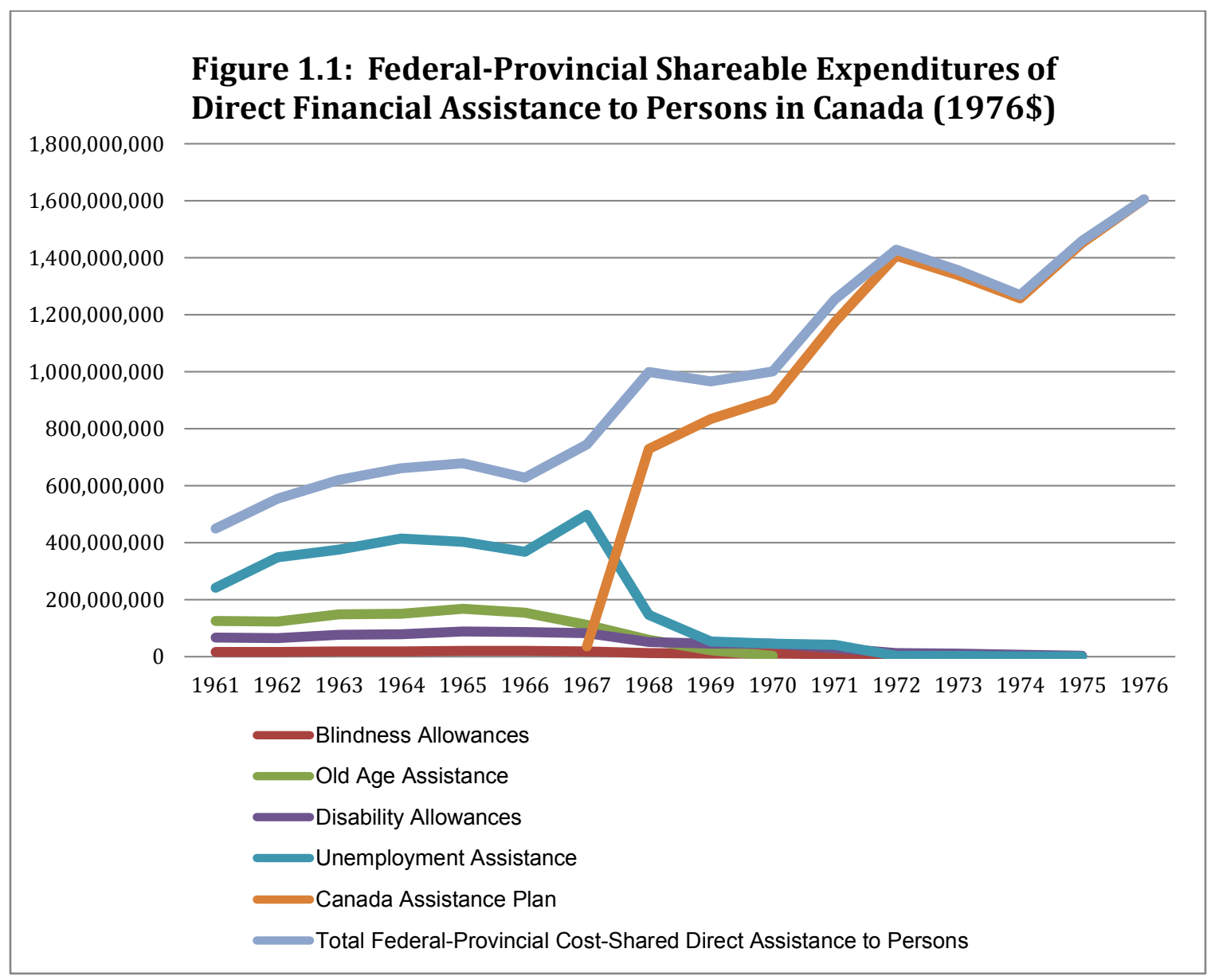

Source. Historical Statistics of Canada. (Series C577-582). Federal-provincial shareable expenditures of direct financial assistance to persons in Canada, fiscal years ending 31 March, 1961 to 1976. Retrieved from http://www.statcan.gc.ca/pub/11-516-x/sectionc/4057749-eng.htm

Notes. Fiscal years ending March 31. Data from 1976 not available, except for CAP and Total. I have converted all figures into 1976 dollars using the Consumer Price Index (Canada). Data at Historical Statistics of Canada web site was expressed in thousands of dollars; I have converted figures into actual dollars. 


\subsubsection{Welfare on Reserves}

CAP had important implications for Indigenous peoples in Ontario, allowing "for the establishment of agreements to extend welfare services in the province to Indians as defined under the Indian Act..." (Moscovitch \& Webster, 1995, p. 38). According to Moscovitch and Webster (1995): “All provinces were unwilling to undertake administration of social assistance for Aboriginal peoples - particularly reserve Indians until CAP in 1966...” (Moscovitch \& Webster, 1995, p. 38).

Prior to 1950, Canadian provinces played virtually no role in delivering social services on reserve. According to Stapleton (2007): "Social Services needs were deemed to be met by the Federal Government under the Section 91 (24) Constitution Act of 1867..." (Stapleton, 2007, p. 6). The federal government "was paying virtually all Indian social assistance costs both on- and off-reserve" (Moscovitch \& Webster, 1995, p. 33). This began to change in 1958 when a Treasury Board minute authorized the federal government "to introduce social work accounting and authorised the gradual replacement of rations with cash" (Moscovitch \& Webster, 1995, p. 33).

After a 1951 amendment to the Indian Act, the Ontario government began developing programs and services for First Nations. The provincial government put First Nations into the Child Welfare Act of 1954, passed the Indian Social Services Act of 1955, extended to First Nations the authority of Indian bands to deliver their own social services programs, and extended GWA to First Nations in 1960 (Stapleton, 2007).

In 1963, a new Liberal government in Ottawa approved in principle the idea of cost-sharing with provinces, as well as "provincial delivery on-reserve..." (Moscovitch \& Webster, 1995, p. 37). Cost-sharing was also emphasized strongly by the federal 
government at the 1964 Federal-Provincial Conference on Indian Affairs (Moscovitch \& Webster, 1995). In July 1964, another Treasury Board minute authorized the federal government "to adopt and generally adhere to social assistance standards approximating those of the relevant province" (Moscovitch \& Webster, 1995, p. 34). And in 1965, a Privy Council Order was approved that gave the federal Department of Indian Affairs ...authority to enter into cost-sharing agreements with the provinces for the extension of welfare services on-reserve. Ontario was the only province to undertake such an agreement: the result was the 1965 Canada-Ontario Memorandum of Agreement Respecting Welfare Programs for Indians. Under the agreement, the federal government reimburses the province for $100 \%$ of the cost of administering social assistance and a selected list of social services for on-reserve Indians (Moscovitch \& Webster, 1995, p. 37).

Social services on reserve were discussed at federal-provincial conferences held in November 1963 and October 1964 respectively. On the heels of these conferences, the Ontario government signed the Indian Welfare Agreement (IWA) with the federal government in 1965. Under the IWA, which had been negotiated in 1964, Ontario agreed to share in the cost of social assistance, child welfare, homemakers and nursing services, and day nurseries (Stapleton, 2007; TAP Associates Ltd., 1979). Ontario would be responsible for the delivery of the services; either the provincial government would deliver them directly, or it would see to it that another body did so. Under the agreement, the federal government would reimburse the provincial government "for the cost of

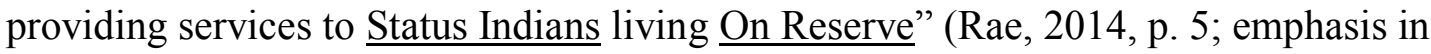
original). All such services would fall under provincial legislation (Rae, 2014). Moreover, in signing the agreement, the Ontario government committed that all of its social welfare services, "present and future, shall be provided to all Indian people in Ontario." As one report noted, "from the point of view of the Government of Ontario, 
with the signing of the Agreement, Indian people became much like other provincial residents, with the same rights to the same welfare services" (TAP Associates Ltd., 1979, p. 61). The federal government had hoped that all provinces would also sign the 1965 IWA agreement, but only Ontario did in the end (Rae, 2014). With these developments, the level of cooperation between the federal and Ontario governments on income assistance was clearly growing.

The IWA also stipulated the order of government that would pay for the various types of social welfare services. Specifically, the agreement stipulated that the federal government would contribute to services provided under the General Welfare Assistance Act, the Child Welfare Act and the Day Care Nurseries Act. However, it also stipulated that the federal government would not fund services falling outside those three pieces of provincial legislation, such as Family Benefits for those considered unemployable, seniors homes, homes for the disabled, and rehabilitation services "for the physically, mentally or socially handicapped" (TAP Associates Ltd., 1979). The agreement also stipulated that the federal government would only provide funding for "registered Indians living on reserves or in unorganized territory, and registered Indians who have lived in a municipality for less than twelve consecutive months" (TAP Associates Ltd., 1979, p. 64). ${ }^{22}$ Each year, for eligible services (i.e., those covered by the three aforementioned pieces of provincial legislation) and eligible persons (i.e., Indians living on reserve either at the time of receipt of service or until a short time before receiving the service) the

\footnotetext{
${ }^{22}$ According to a 1979 report: "In practice, the Province does not usually record whether a client living off a reserve is Indian or not, nor does it make a note of how long the person has been in a municipality. So, in fact, the Provinces makes claim under the Agreement for services provided to Indian people on reserves, and rarely for those who have moved away" (TAP Associates Ltd., 1979, p. 64).
} 
federal contribution ended up constituting approximately 95 percent of the actual cost incurred by the provincial government (TAP Associates Ltd., 1979).

According to a 1979 report, each year, the cost of these services rose substantially:

During the first full operating year of the Agreement, 1966-1967, Provincial costs for that year were $\$ 1$ million. In 1977-1978, these costs were \$9.6 million. So there has been a sharp rise in the amount spent annually under the Agreement; the average annual increase in spending has been in the order of $23 \%$. Part of this increase reflects the rise in allowances and in cost of putting service into the field, but the largest part reflects the progressive expansion of all four programs to more and more of the reserves (TAP Associates Ltd., 1979, p. 73).

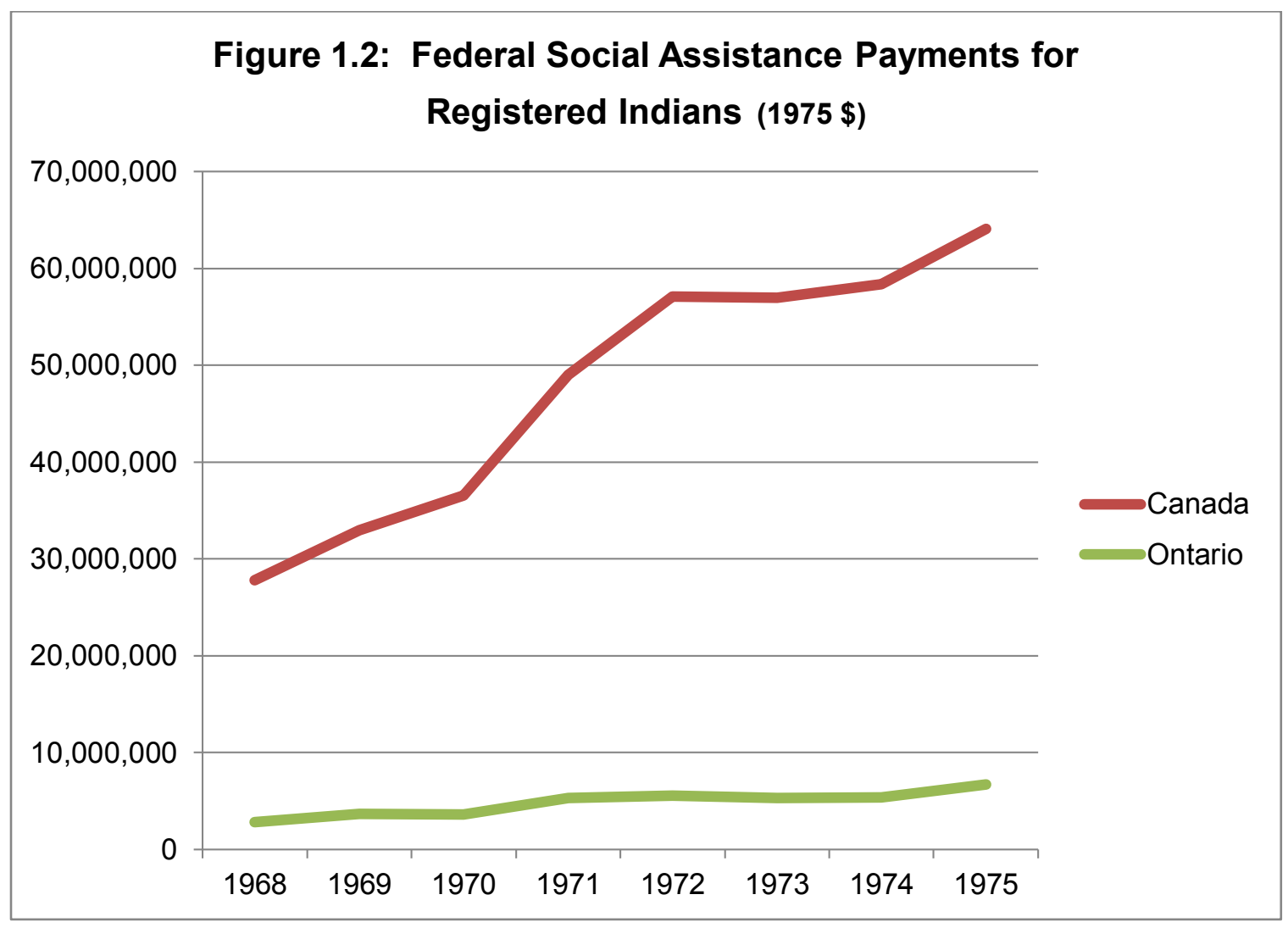

Source. Historical Statistics of Canada, Series C144-156.

Notes. Years are for fiscal years ending March 31. Using the Consumer Price Index, I have converted figures into 1975 dollars. 
As can be seen from data presented in Figure 1.2, the IWA indeed had important implications for spending. Between 1968 and 1975, annual federal social assistance payments for registered Indians for Canada as a whole increased by 131 percent (after adjusting for inflation). For Ontario, they increased by 138 percent in real terms (Historical Statistics of Canada, Series C144-156).

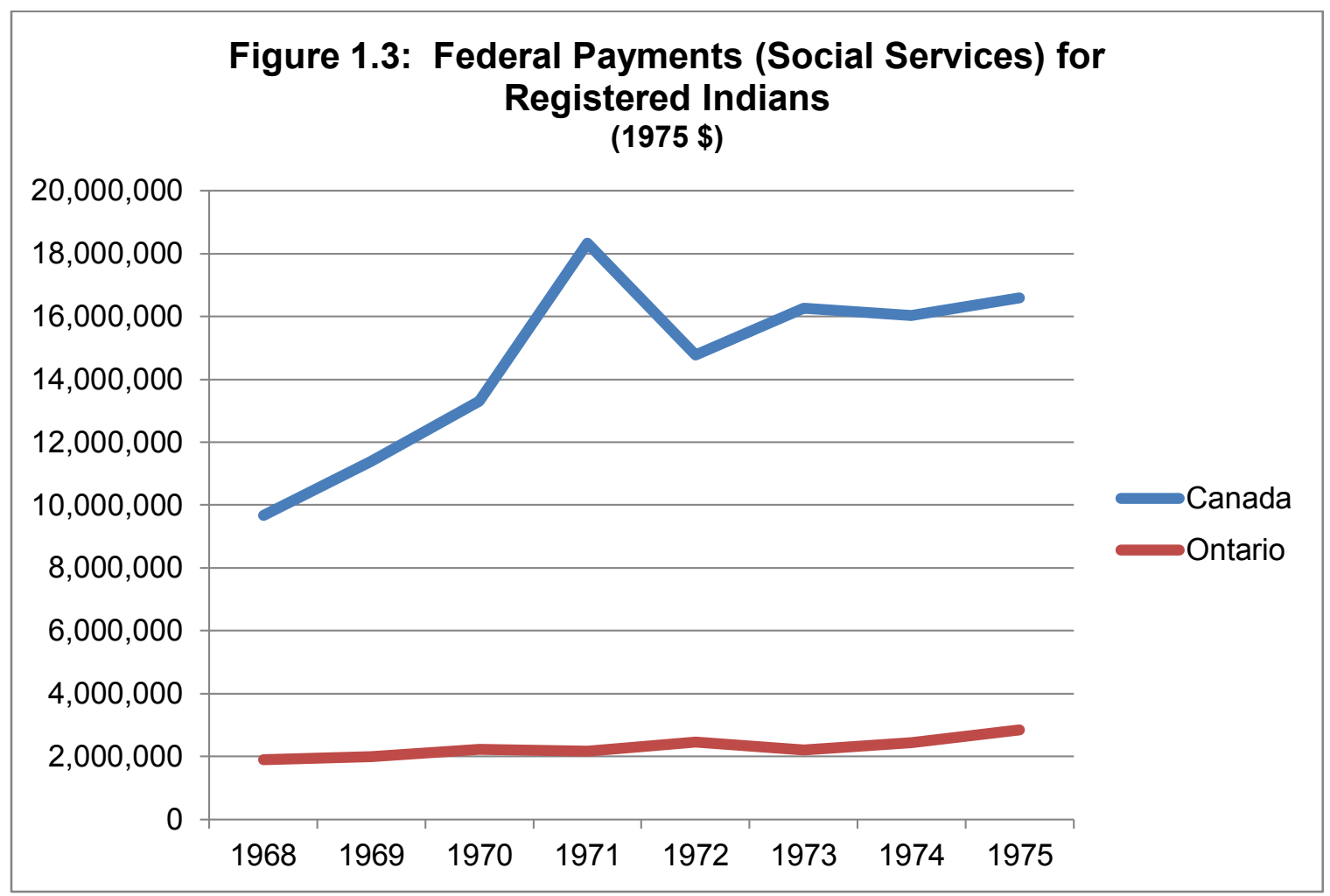

Source. Historical Statistics of Canada, Series C495-507.

Notes. Social services here consist of care of adults, child care, rehabilitation and other welfare services. These are for fiscal years ending March 31. I have converted figures into 1975 dollars using the Consumer Price Index (Canada).

Likewise, between 1968 and 1975, annual federal payments for social services for Registered Indians across Canada increased by 72 percent (after adjusting for inflation). Over the same seven-year period, Ontario saw a corresponding increase of 50 percent (Historical Statistics of Canada, Series C495-507). 


\subsubsection{General Welfare Assistance}

The General Welfare Assistance Amendment Act was passed at Queen's Park in 1967, receiving Royal Assent in March of that year (General Welfare Assistance Amendment Act, 1967)_ _ just eight months after CAP had received Royal Assent. Like the CAP, this amendment to provincial legislation took effect beginning in the 1967-1968 fiscal year (General Welfare Assistance Amendment Act, 1967; SPCMT \& OWC, 1977). Effectively the CAP's 'opting in' legislation, it was a needs-tested program (i.e., budgetary requirements less income) intended to provide temporary assistance to persons in need. ${ }^{23}$ A 1977 report provides a breakdown of which level of government paid for each component of this temporary assistance:

General Welfare Assistance is paid for by the municipalities and regional governments that administer it. They recover from the Province 80 per cent of the costs of General Assistance, Supplementary Aid, staff training costs, incentive allowances and work activity project costs; and 50 per cent of the costs of Special Assistance and certain administration costs. (Thus, the costs of General Assistance are shared respectively by Canada, Ontario, and the municipal unit in the ratio of 50 : 30 : 20.) (SPCMT \& OWC, 1977; emphasis in original).

The General Welfare Assistance (GWA) Act, together with regulations, established provincial standards that were administered by local governments (Yaremko, 1970). GWA was typically administered by municipalities, the exception being in northern areas of Ontario which lacked "municipal organization." In those cases, the Province administered GWA (Yaremko, 1970, p. 24). Benefits-intended for persons

\footnotetext{
${ }^{23}$ Not all 'persons in need' were eligible for GWA. According to a 1970 brief, "a person taking postsecondary education is not eligible for assistance. There is, however, an important exception: eligible women who are heads of families may receive assistance while continuing their education at any level" (Yaremko, 1970, p. 15).
} 
with "shorter term needs" (relative to those with permanent disabilities)—were distributed via "weekly or monthly cheques" (Yaremko, 1970, p. 14).

In a 1970 brief to a Senate committee, the Minister of Social and Family Services explained the administration of GWA as follows:

Municipalities and Indian bands provide assistance to eligible persons who are in need within their jurisdictions. In unorganized areas where there are no municipalities, the Department of Social and Family Services is directly responsible. Provision has been made for municipalities to join together into a county or district for the purpose of administering General Welfare Assistance over larger geographical areas (Yaremko, 1970, p. 14).

In some cases, a household could receive Supplementary Aid through GWA. Recipients received other forms of income assistance — such as Old Age Security or Family Benefits (to be discussed below) — but required additional funding to supplement the relatively modest amounts that they were getting from those other sources. Supplementary Aid was "granted mainly for high drug and shelter costs" (SPCMT \& OWC, 1977, p. 85). After the municipality provided funding for Supplementary Aid, it could receive 80 percent of the amount back from the provincial government. Prior to 1974, the maximum monthly amount on which the municipality could be reimbursed at 80 percent was $\$ 20$. In 1974 , that ceiling was removed. In real terms, annual expenditure on Supplementary Aid across Ontario increased by more than 400 percent between the 1967-68 and 1974-75 fiscal years (SPCMT \& OWC, 1977).

GWA also included a provision for Special Assistance, the costs of which were shared 50:50 between the province and the municipality in question (SPCMT \& OWC, 1977). Special Assistance covered such things as:

prescribed drugs, travel and transportation allowance, funerals and burials, dental services, optical services, prosthetic appliances including eyeglasses, vocational training or retraining [and] nursing home comfort allowance...In 1970, surgical 
supplies and dressings, and moving allowances were added to the list of items...(SPCMT \& OWC, 1977, p. 26).

Between fiscal years 1967-68 and 1974-75, annual expenditures for Special Assistance across the province increased by more than 230 percent in real terms (SPCMT \& OWC, 1977).

The three main components of GWA are illustrated in Table 1.2.

\section{Table 1.2}

Main Components of General Welfare Allowance, 1970

\begin{tabular}{ll}
\hline Name of Component & Purpose \\
\hline General Assistance & Day-to-day living expenses. \\
& $\begin{array}{l}\text { It was intended to cover food, clothing, shelter and } \\
\text { utilities. }\end{array}$ \\
& There was a maximum monthly amount that varied \\
& according to household size. \\
\hline Special Assistance & This could be provided at the discretion of the local \\
& $\begin{array}{l}\text { welfare administrator for such things as prescription } \\
\text { medication, dental work, medical appliances, } \\
\text { eyeglasses, transportation, training, funerals and } \\
\text { burials. }\end{array}$ \\
\hline Supplementary Aid & $\begin{array}{l}\text { At the discretion of the local welfare administrator, this } \\
\text { type of assistance was available for recipients of other } \\
\text { types of government benefits, such as Old Age } \\
\text { Security or Family Benefits. }\end{array}$ \\
& It was intended to help meet "extraordinary needs." \\
\hline
\end{tabular}

Note. Source for the above information is Yaremko, 1970. Quote is taken from page 15.

In terms of funding flow, GWA was, in the first instance,

paid for by the municipalities and regional governments that [administered] it. They [in turn recovered] from the Province 80 per cent of the costs of General Assistance, Supplementary Aid, staff training costs, incentive allowances and work activity project costs; and 50 per cent of costs for Special Assistance and certain administration costs (SPCMT \& OWC, 1977, p. 16). 
As might be expected in light of CAP's stipulations, neither GWA applicants nor recipients could be denied assistance for not accepting employment. However, Ontario Regulation 293/76 stipulated that 'employable persons' applying for or receiving benefits were required to search for employment in such a fashion that their welfare administrator was satisfied with the effort (SPCMT \& OWC, 1977).

According to 1970 regulations, households applying for GWA were asked to disclose information about marital status (and their living arrangement), places of residence, current and future sources of income (including other sources of public assistance), assets and debts (General Welfare Assistance Act: Regulations 383 under the General Welfare Assistance Act, 1970). According to a 1970 brief prepared for the Special Senate Committee on Poverty:

Upon application for General Assistance or Special Assistance an applicant's liquid assets are examined to determine what resources he has to support himself. Liquid assets include "cash, bonds, debentures, stocks, the beneficial interest in assets held in trust and available to be used for maintenance, and any other assets that can readily be converted into cash". Each municipality determines how it will treat assets: no exemptions are set out in the legislation...For General Assistance the allowance is determined, after taking liquid assets into account, by totalling budgetary requirements and deducting income. In general, all income is taken into consideration, but there are some mandatory exemptions including Family and Youth Allowances (Yaremko, 1970, p. 16).

Whereas every person applying for FBA was required to submit a medical report completed by a physician, the only GWA applicants who had to do so were those claiming to be "unemployable" or who were residents of a nursing home (General Welfare Assistance Act: Regulations 383 under the General Welfare Assistance Act, 1970). 
In addition to benefits received, GWA recipients were also allowed to receive some earned income (subject to restrictions). In principle, a dollar of earned income resulted in one less dollar in benefits received; however, the welfare administrator was permitted to exempt a relatively modest amount of earned income, the maximum of which is indicated in Table 1.3. For every dollar earned by a GWA recipient household that was in excess of those maximum thresholds, 75 cents was 'clawed back' from future benefits (General Welfare Assistance Act: Regulations 383 under the General Welfare Assistance Act, 1970). In this way, the principle of less eligibility was being upheld in two important respects. First, by allowing recipients to keep some earned income, recipients had incentive to continue seeking work while in receipt of welfare. Second, by placing restrictions on how much earned income they could keep, no GWA recipient would be made so well off that they might lose financial incentive to seek full-time employment.

\section{Table 1.3}

Monthly earnings exemptions for GWA recipients, 1970

\begin{tabular}{ccc}
\hline Number of children & One adult & Two adults \\
\hline 0 & $\$ 24$ & $\$ 36$ \\
\hline 1 & $\$ 36$ & $\$ 48$ \\
\hline 2 & $\$ 48$ & $\$ 60$ \\
\hline 3 & $\$ 60$ & $\$ 72$ \\
\hline 4 & $\$ 72$ & $\$ 84$ \\
\hline 5 & $\$ 84$ & $\$ 96$ \\
\hline $6^{\mathrm{a}}$ & $\$ 96$ & $\$ 108$ \\
\hline
\end{tabular}

Note. The source for this information is General Welfare Assistance Act: Regulations 383 under the General Welfare Assistance Act, 1970.

${ }^{a}$ For each additional child after the sixth, add an additional $\$ 12$ to the figure in each column. 


\subsubsection{Family Benefits Assistance}

In April 1967, the Family Benefits Act (FBA) took effect, after having been passed at Queen's Park the previous year (SPCMT \& OWC, 1977). Like GWA, it was a needs-tested program administered by the province's Department of Social and Family Services. Unlike GWA, it was intended for "persons likely to be in need for extensive periods of time" (Yaremko, 1970, p. 14) — that is, it was intended for 'unemployables.' As of 1970, FBA had 19 regional offices; and eligibility determination for all FBA applications occurred in Toronto (Yaremko, 1970). According a brief to a Senate committee: "The field staff take information from applicants and send completed applications and supporting documents to the Department of Social and Family Services in Toronto where the determination of eligibility is made and the actual amount of allowance is calculated" (Yaremko, 1970, p. 22).

While GWA was a municipally-administered program intended to provide temporary assistance to households in need, the FBA was a provincial program intended to provide "long-term support" to persons in need (SPCMT \& OWC, 1977, p. 18). Benefits were provided every month and were intended to cover such things as "food, clothing [and] shelter..." (Yaremko, 1970, p. 17). Household types for which it was intended included: persons with recognized disabilities; "mothers with dependent children;" persons 65 years of age or older not receiving Old Age Security benefits; and women between the ages of 60 and 65 who are not receiving financial support from a spouse or former spouse. A key advantage of introducing the FBA legislation and doing away with the other programs was to "take advantage" of CAP legislation (SPCMT \& OWC, 1977, p. 19). 
According to a report written jointly by the Social Planning Council of

Metropolitan Toronto and the Ontario Welfare Council:

the new Family Benefits program encompassed groups of people previously covered under other separate legislation, such as the Blind Persons' Allowances Act, the Disabled Persons' Allowances Act, the Old Age Assistance Act, the Mothers' Allowance Act, and the Dependent Fathers' and Widows and Unmarried Women sections of the GWA Act. These programs were gradually phased out over the next few years, as people previously covered by these programs were transferred to Family Benefits (SPCMT \& OWC, 1977, p. 19).

Writing about the transition of households from the Ontario Mothers' Allowance program to FBA, Little (1998) notes:

FBA broadened eligibility in the following ways: the age of children attending school and 'making satisfactory progress' was increased from eighteen to twentyone; universal medical and hospital insurance with premium-free coverage for all persons of low income; waiting period for deserted mothers reduced from six to three months (Little, 1998, pp. 194-195).

While the change in criteria did broaden which groups the state was now considering to be 'unemployable,' these developments should not be exaggerated. Little (1998) argues that the transition to FBA “minimally altered eligibility requirements" and that "eligibility qualifications for the majority of single mothers remained unchanged from the previous era...(Little, 1998, p. 142; emphasis added).

Households applying for FBA—like households applying for GWA—were asked information about marital status (and living arrangements), places of residence, current and future sources of income (including other sources of public assistance), assets and debts (Family Benefits Act: Regulation 287 under The Family Benefits Act, 1970).

According to a 1970 brief prepared for the Special Senate Committee on Poverty:

Liquid assets are examined and then if these have a value before certain limits, need is determined by totalling budgetary requirements and deducting income. The difference is the amount of the allowance. The definition of liquid assets is almost the same as for General Assistance. There are, however, basic exemptions 
of assets. For a single person the exemption is $\$ 1,000$; for families the exemption varies according to the number of family members (Yaremko, 1970, p. 18).

Unlike most persons applying for GWA, those applying for FBA were also asked to submit a medical report completed and signed by a physician; in effect, recipients were being asked to prove that they were in fact 'unemployable.' The medical report asked questions about the extent to which the person's disability (or disabilities) would likely impact their ability to sustain gainful employment (Family Benefits Act: Regulation 287 under The Family Benefits Act, 1970).

In addition to benefits received, FBA recipients (like GWA recipients) were also allowed to receive some earned income subject to restrictions. In principle, a dollar of earned income resulted in one less dollar in benefits received; however, the FBA official was permitted to exempt a relatively modest amount of earned income, the maximum of which is indicated in Table 1.4. For every dollar earned by an FBA recipient household that was in excess of those maximum thresholds, 75 cents was 'clawed back' from future benefits (Family Benefits Act: Regulation 287 under The Family Benefits Act, 1970). Even though the GWA and FBA programs were created by separate legislation and were subject to their own respective regulations and policies, the reader will note that the FBA earnings exemptions in place in 1970 were precisely the same as those for GWA recipients. This was a curious development in light of the fact that one group was considered employable and the other unemployable. Admittedly, the state appeared to be less vigilant in upholding the principle of less eligibility to unemployables insofar as it was providing higher benefit levels for FBA recipients than for GWA recipients (to be further discussed below). Nevertheless, it is noteworthy that earnings exemptions were just as strict for the former group as they were for the latter. 
Table 1.4

Monthly earnings exemptions for FBA recipients, 1970

\begin{tabular}{ccc}
\hline Number of children & One adult & Two adults \\
\hline 0 & $\$ 24$ & $\$ 36$ \\
\hline 1 & $\$ 36$ & $\$ 48$ \\
\hline 2 & $\$ 48$ & $\$ 60$ \\
\hline 3 & $\$ 60$ & $\$ 72$ \\
\hline 4 & $\$ 72$ & $\$ 84$ \\
\hline 5 & $\$ 84$ & $\$ 96$ \\
\hline $6^{\text {a }}$ & $\$ 96$ & $\$ 108$ \\
\hline
\end{tabular}

Note. The source for this information is Family Benefits Act: Regulation 287 under The Family Benefits Act, 1970.

${ }^{\mathrm{a}}$ For each additional child after the sixth, add an additional $\$ 12$ to the figure in each column. 


\subsubsection{GWA vs. FBA}

The fact that GWA was administered largely by municipalities appears to have led to some significant variation in benefit levels across Ontario. For example, in 1969, average monthly expenditure per beneficiary for General Assistance ranged from $\$ 26$ in Nipissing District to $\$ 71$ in Ottawa-Carleton. Average monthly expenditure per beneficiary for Special Assistance that year varied from \$11 in Windsor to \$171 in Oshawa. Finally, average monthly expenditure per beneficiary in 1969 for Supplementary Aid ranged from $\$ 10$ in Cochrane District to $\$ 31$ in Prescott-Russell. By contrast, FBA benefits did not experience much variation across the province. The same year, the lowest average FBA expenditure per recipient was $\$ 62$, in Nipissing District; the highest was just \$76, in Metro Toronto (Yaremko, 1970).

It was common for households to transition either from GWA to $\mathrm{FBA}^{24}$ or from FBA to GWA. For example, a household could receive GWA while waiting for a ruling on their FBA application. Likewise, a household could be suspended from FBA and receive GWA benefits while 'in limbo.' Further, a household could cease being eligible for FBA (e.g., in the case of a mother whose dependents advance in age) and subsequently receive GWA benefits (Yaremko, 1970).

\footnotetext{
${ }^{24}$ The reader may note that the transition from GWA to FBA is a topic that is particularly germane to Essay 2 of the present dissertation.
} 


\subsubsection{Scope and Generosity of Benefits}

GWA benefit levels grew modestly between 1967 and 1976. During that period, in real terms, the monthly allowance for a single male under age 65 increased by 14.8 percent. For a mother with a child aged four, it increased by 9.0 percent; for a mother with three children (aged three, six and eight respectively), it increased by 3.8 percent; and for a mother, father and two children (aged 10 and 13 respectively), it increased by 2.4 percent (SPCMT \& OWC, 1977). However, it is also clear that benefit levels increased very substantially from 1961 to 1976 (Figure 1.4). For a single male under the age of 65 , for example, they nearly doubled during this 15 -year period. It would definitely appear that the state appeared to be siding with workers more than capital over this period. 


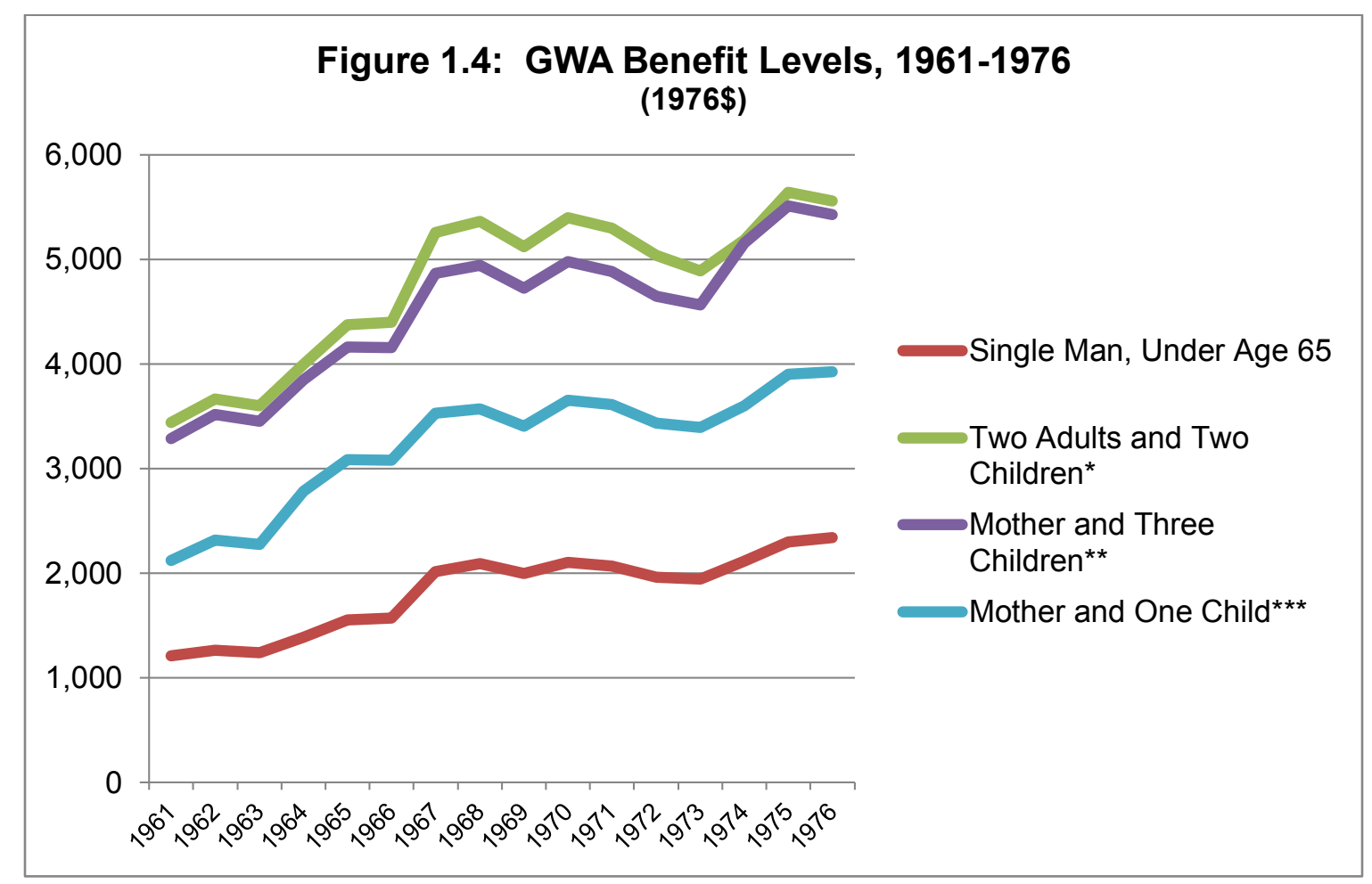

Source. Social Planning Council of Metropolitan Toronto and the Ontario Welfare Council. (1977). Social allowances in Ontario: An historical analysis of general welfare assistance and family benefits.

Notes. All figures are annual. I have converted figures into 1976 dollars using the Consumer Prince Index (Canada). Figures for Single Men Under 65 have been taken from Table 11 (p. 65). Figures for "Two Adults and Two Children" have been taken from Table 12 (p. 66). Figures for "Mother and Three Children" have been taken from Table 13 (p. 67). Figures for "Mother and One Child" have been taken from Table 14 (p. 68).

*Specifically: "Father, Mother, Two Children Under 16 (aged 10, 13)." Also, figures in this column include Family Allowance benefit amounts.

**Specifically: "Mother and Three Children Under 16 years (aged 3,6,8)." Also, figures in this column include Family Allowance benefit amounts.

${ }^{* * *}$ Specifically: "Mother and Child age 4." Also, figures in this column include Family Allowance benefit amounts.

From 1967 until 1975, recipients of Family Benefits also witnessed a modest increase in monthly allowances. Indeed, a mother with a four-year-old child saw her monthly allowance (in real terms) increase by 12.6 percent between 1967 and 1975; a mother with three children (aged three, six and eight respectively) saw the inflationadjusted value of her monthly allowance increase by 7.3 percent during this period; and a mother and father with two children (aged 10 and 13 respectively) saw the real value of 
their monthly allowance increase by 6.5 percent during this time (SPCMT \& OWC, 1977).

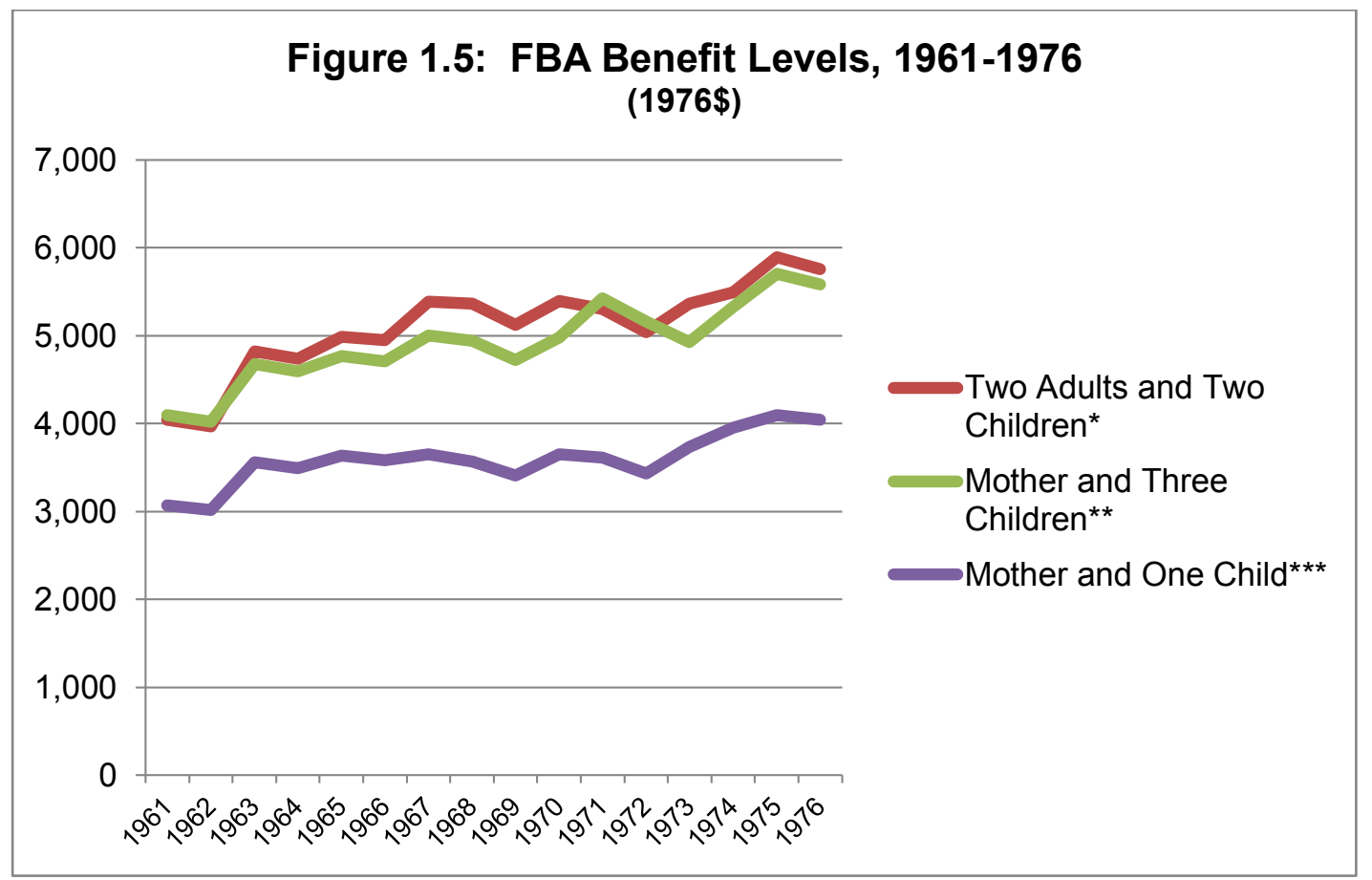

Source. Social Planning Council of Metropolitan Toronto and the Ontario Welfare Council. (1977). Social allowances in Ontario: An historical analysis of general welfare assistance and family benefits.

Notes. All figures are annual and include Family Allowance benefit amounts. I have converted figures into 1976 dollars using the Consumer Prince Index (Canada). Figures for "Two Adults and Two Children" have been taken from Table 12 (p. 66). Figures for "Mother and Three Children" have been taken from Table 13 ( $p$. 67). Figures for "Mother and One Child" have been taken from Table 14 (p. 68).

*Specifically: "Father, Mother, Two Children Under 16 (aged 10, 13)."

**Specifically: "Mother and Three Children Under 16 years (aged 3,6,8)."

***Specifically: "Mother and Child age 4."

In September 1974, the Ontario government brought in a regulation providing coverage to all recipients of both GWA and FBA (as well as recipients of OAS and GAINS) for "the cost of drugs prescribed by a physician or dental surgeon" (SPCMT \& OWC, 1977, p. 25).

A 1977 report included the following description of dental coverage for GWA and FBA recipients: 
Assistance for dental services has varied. Regulations provide for certifiable emergency extractions only; provision of preventive or other services is discretionary. Children in school have usually been covered, their parents sometimes, and single persons have generally received no services (SPCMT \& OWC, 1977, p. 26).

\subsubsection{Growth of Caseloads}

Between 1968 and 1975, GWA cases in Ontario increased by 57 percent and FBA cases increased by 49 percent; yet, during the same seven-year period, Ontario's total population increased by a mere 13 percent (SPCMT \& OWC, 1977), and average weekly wages saw sizeable growth (Historical Statistics of Canada, Series E49-59). ${ }^{25}$ Essay 3 of the present dissertation makes clear that assessing the determinants of caseload growth is a challenging exercise that requires a considerable amount of empirical effort. Though I have not undertaken such an analysis of caseload growth during the 1968-1975 period, several factors are likely to have contributed to caseload growth during this time. One is rising unemployment; indeed, during the 1968-1975 period, Ontario's official unemployment rate increased from 3.5 percent to 6.0 percent (Historical Statistics of Canada, Series D491-497). ${ }^{26}$ Another is in-migration: between 1966 and 1976, Ontario saw net in-migration of over 600,000 persons (Historical Statistics of Canada, Series A339-349). A third is benefit levels — as noted above, there was a modest increase in (inflation-adjusted) benefit levels for both GWA and FBA, and this may have led to some increase in caseloads.

\footnotetext{
${ }^{25}$ After adjusting for inflation, average weekly wages in Ontario rose by 15 percent during this period (Historical Statistics of Canada, Series E49-59).

${ }^{26}$ See Appendix 1.3 .
} 


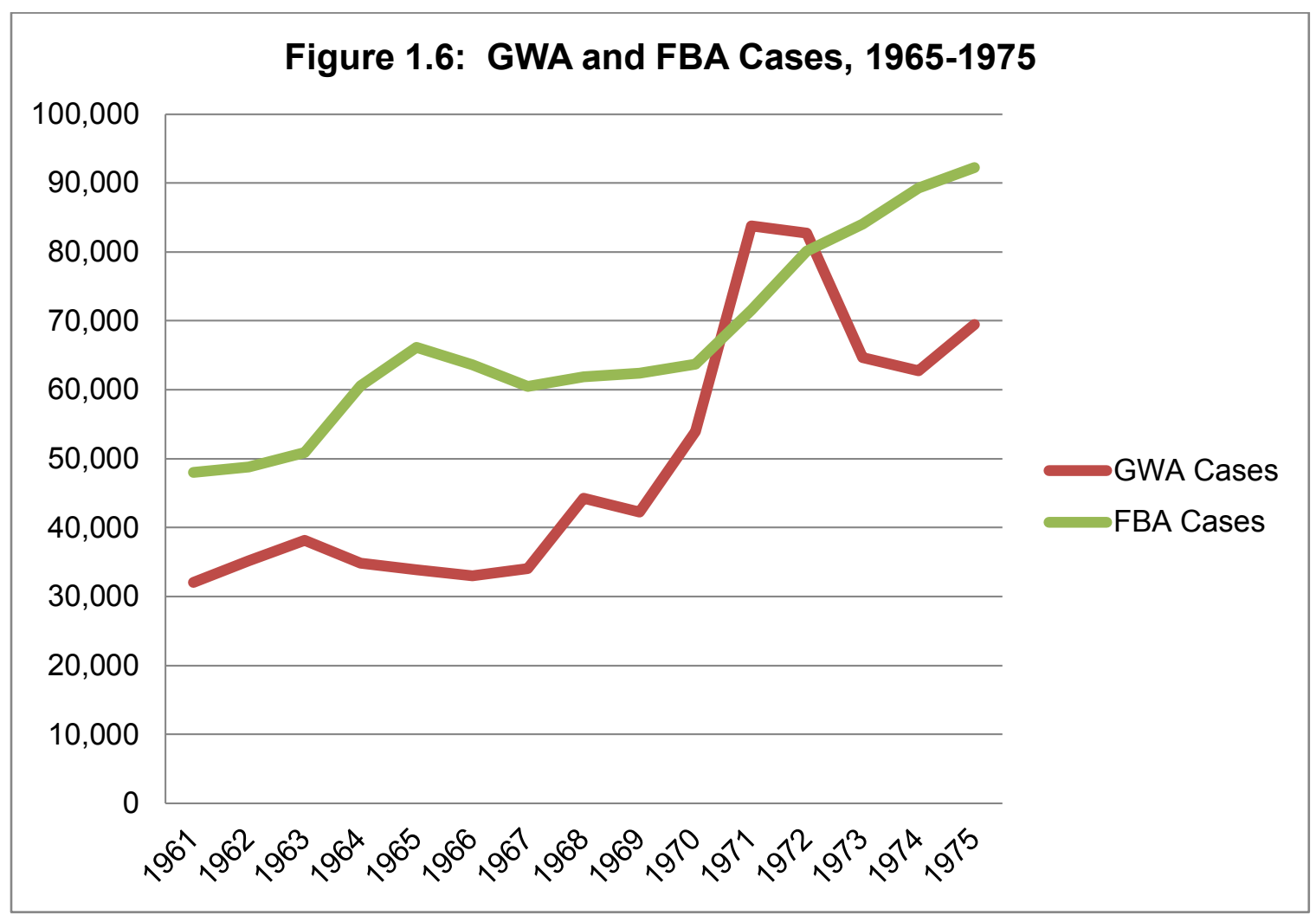

Source. Social Planning Council of Metropolitan Toronto and the Ontario Welfare Council. (1977). Social allowances in Ontario: An historical analysis of general welfare assistance and family benefits. Primary Data Source: Annual Reports and Statistical Supplements of the Ministry of Community \& Social Services. Note. Figures for 1961-1967 are for Welfare Allowances, which were FBA's predecessor programs. 


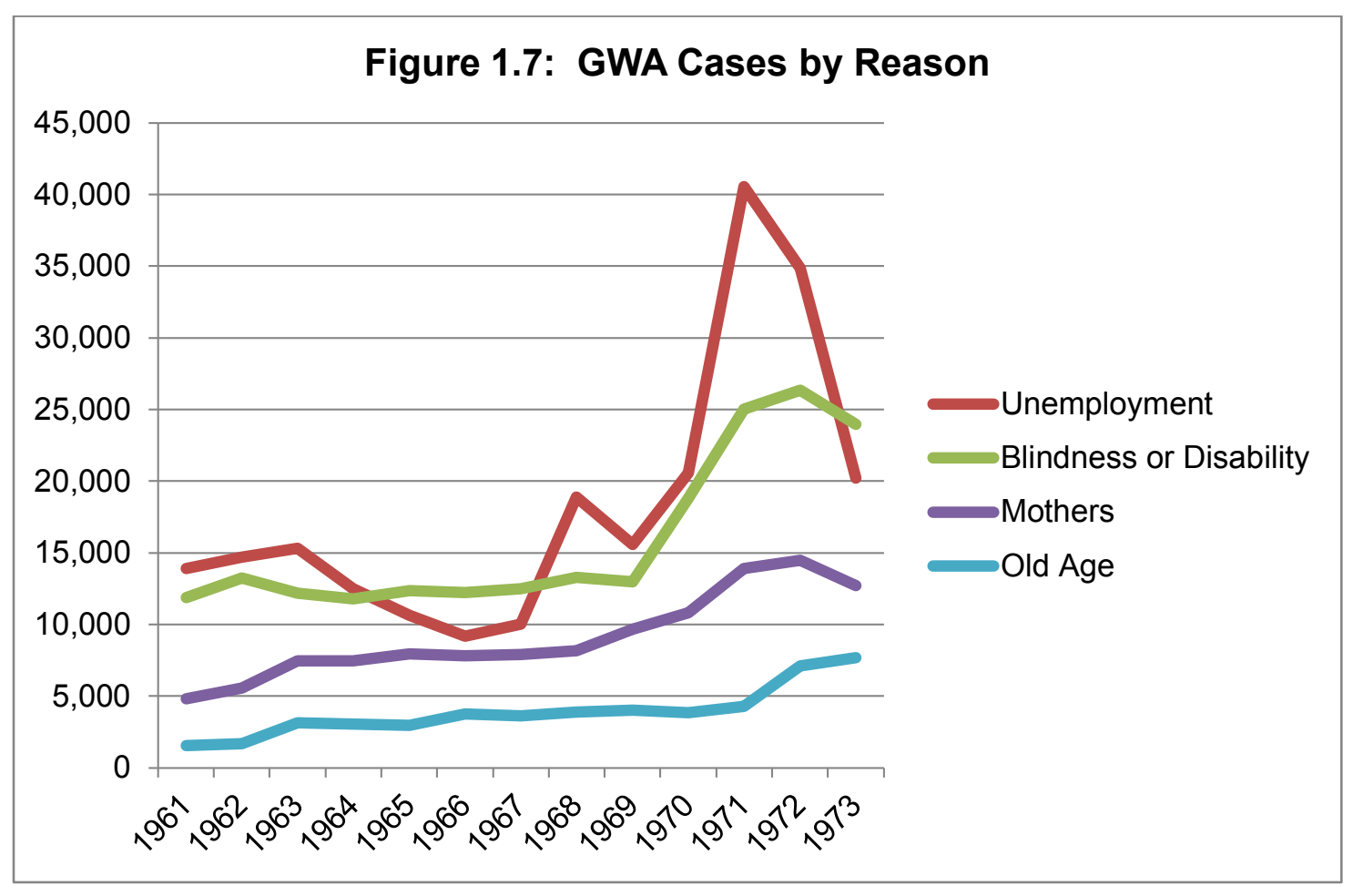

Source. Social Planning Council of Metropolitan Toronto and the Ontario Welfare Council. (1977). Social allowances in Ontario: An historical analysis of general welfare assistance and family benefits. This data has been taken from Appendix $C$ of the report.

Note. Years are fiscal years.

Figure 1.7 shows how specific categories of GWA cases increased between 1961 and 1973. Where unemployment is cited as the reason for a person's GWA receipt, there is a steep rise in cases between 1966 and 1971; during those same years, Ontario's official unemployment rate more than doubled, moving from 2.5 percent to 5.2 percent (Historical Statistics of Canada, Series D491-497). ${ }^{27}$ It is very highly like that that steep rise in unemployment contributed to this rise in GWA cases. Rising unemployment may have contributed to the rises in caseloads for households from other categories as well; it may be that when unemployment was very low, many such persons were able to find

\footnotetext{
${ }^{27}$ See Appendix 1.3.
} 
gainful employment in spite of their disability, old age or family status. But when unemployment was more severe, they felt they had little choice but to apply for GWA benefits. Put differently, a jurisdiction's level of unemployment likely influences which workers are in fact 'employable,' and which are 'unemployable.'

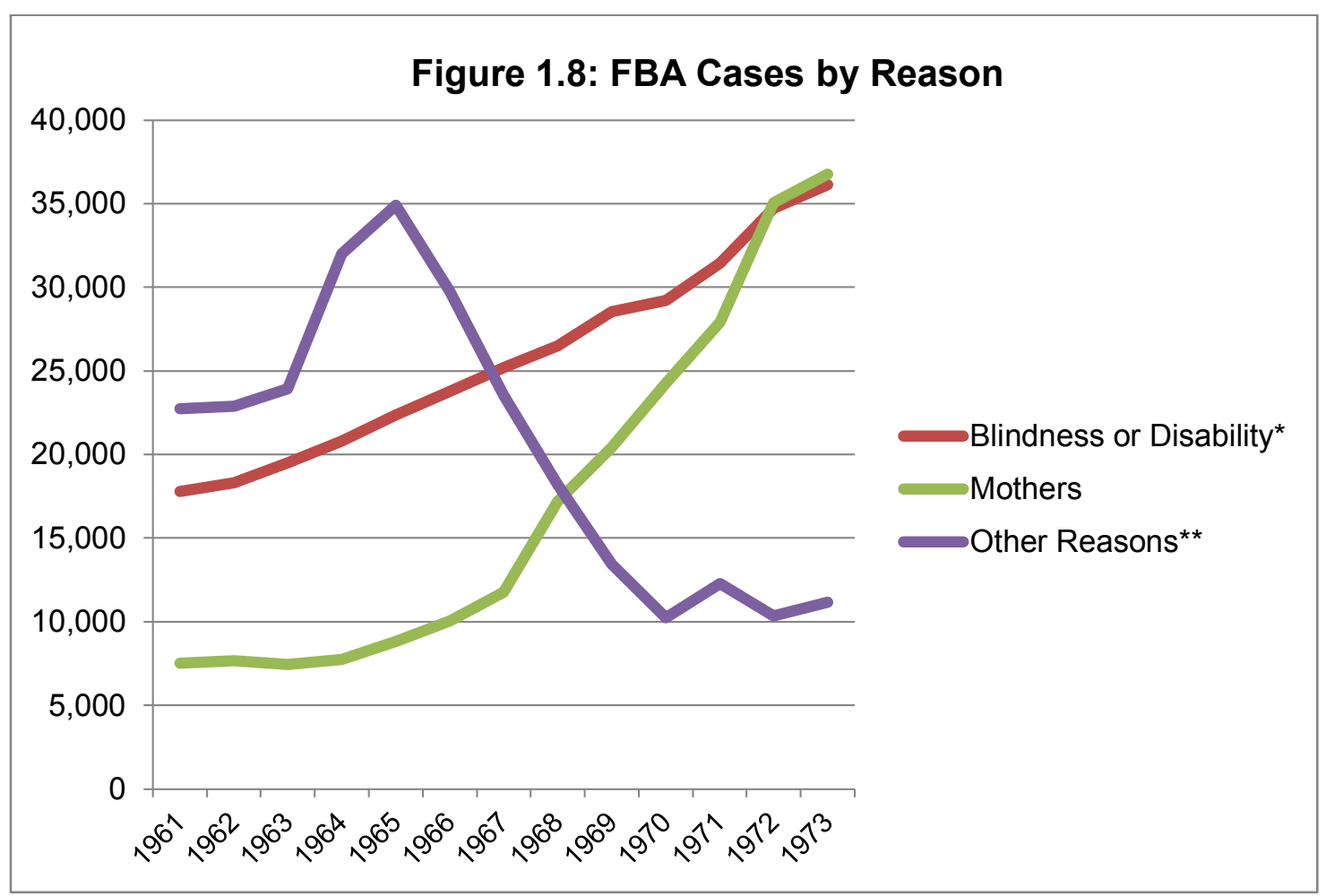

Source. Social Planning Council of Metropolitan Toronto and the Ontario Welfare Council. (1977). Social allowances in Ontario: An historical analysis of general welfare assistance and family benefits.

Notes. These figures have been taken from Appendix C, found on page 89 of the report. Years are fiscal years. *Blindness or Disability category includes dependent fathers.

**Other Reasons include Old Age and Women aged 60-65. For fiscal years 1961, 1962 and 1963, figures in this column represent Old Age Assistance only. For fiscal years 1964, 1965, 1966 and 1967, figures in this column represent Old Age Assistance and Widows and Unmarried Women cases only.

Figures presented in Figure 1.8 suggest that, on the surface, rises in FBA caseloads in the years after CAP's passage were driven by two major trends: first and foremost, the transition of dependent mothers from the aforementioned mothers' allowance program to the new FBA program (which, as discussed earlier, included more 
liberal eligibility criteria); and second, claims related to disability. ${ }^{28}$ It may also be that increases to benefit levels and a rise in unemployment exacerbated the upward trend in FBA caseloads during this time.

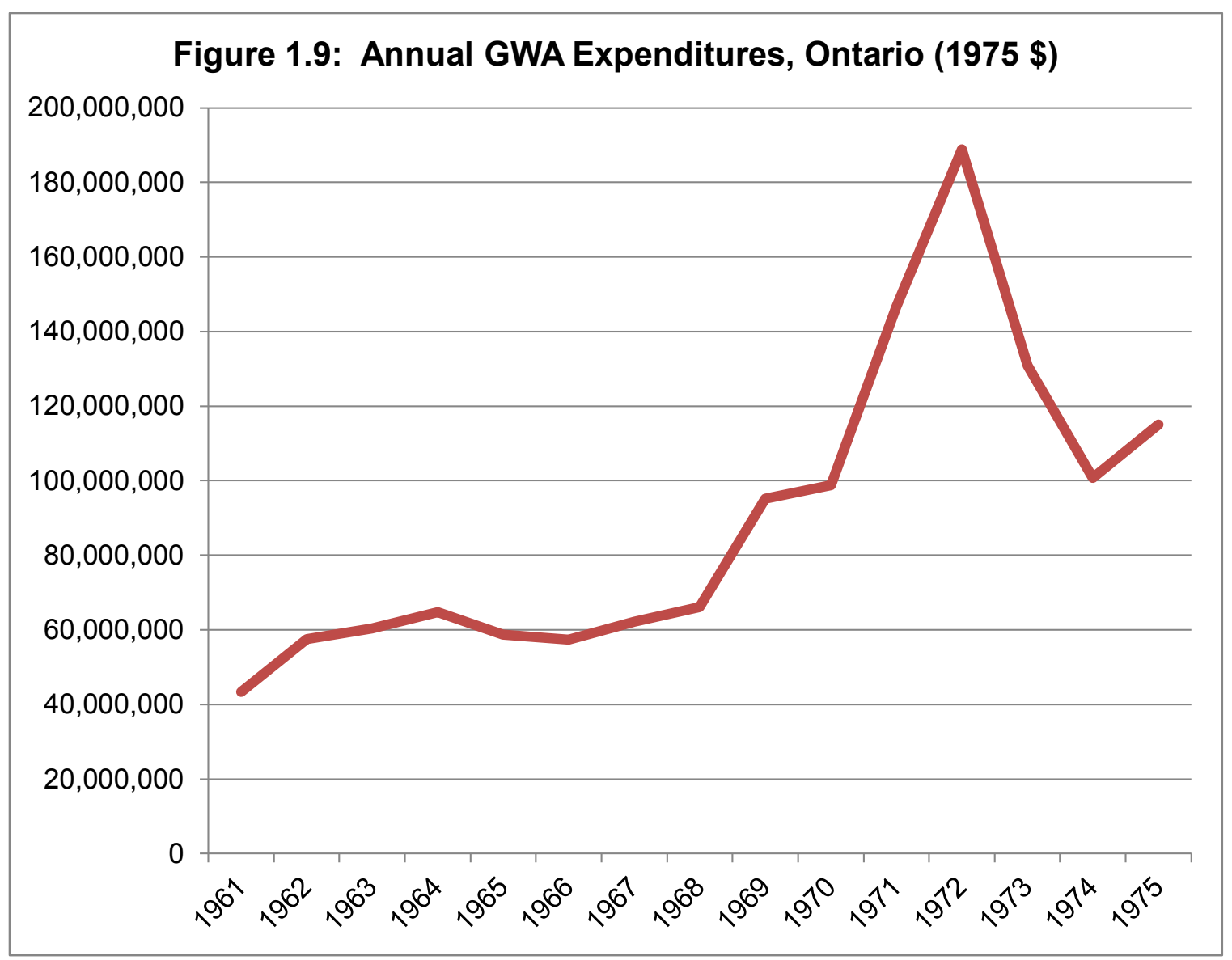

Notes. This information has been taken from: Social Planning Council of Metropolitan Toronto and the Ontario Welfare Council. (1977). Social allowances in Ontario: An historical analysis of general welfare assistance and family benefits. Primary Data Sources. Annual reports of the Ontario Department of Social and Family Services, 1961-1962 to 1969-1970; Statistical Supplements to annual reports 1970-1971, 1971-1972, 1972-

1973; Quarterly Statistical Bulletin, January-March 1975, Ontario Ministry of Community \& Social Services; Ministry of Community \& Social Services GWA Summary Tables for 1973-1974 and 1974-1975. Figures include expenditures on General Assistance Allowances, Supplementary Aid and Special Assistance. Administration costs and medical services are excluded. Figures from 1960-1961 until 1966-1967 include "expenditures on rehabilitation, burial of indigents, dental accounts, and miscellaneous; as well as expenditures for Supplementary Aid to recipients of other governmental allowances." Figures from 1960-1961 until 19661967 also include "assistance to Indians and dependent foster children." I have adjusted figures to 1975 dollars using the Consumer Price Index.

${ }^{28}$ By contrast, after reaching a high point of 34,915 cases in 1965 , FBA claims related to 'old age' saw a sharp, downward trend that continued into the early 1970s. 
Between 1969 and 1975, the annual (inflation-adjusted) value of direct financial assistance provided as cost-shared payments under CAP, for Canada as a whole, increased by 93 percent. For Ontario, it increased by 95 percent (Historical Statistics of Canada, Series C430-442) — something that will not surprise the reader, in light of the aforementioned rise in GWA and FBA caseloads during this same period. 


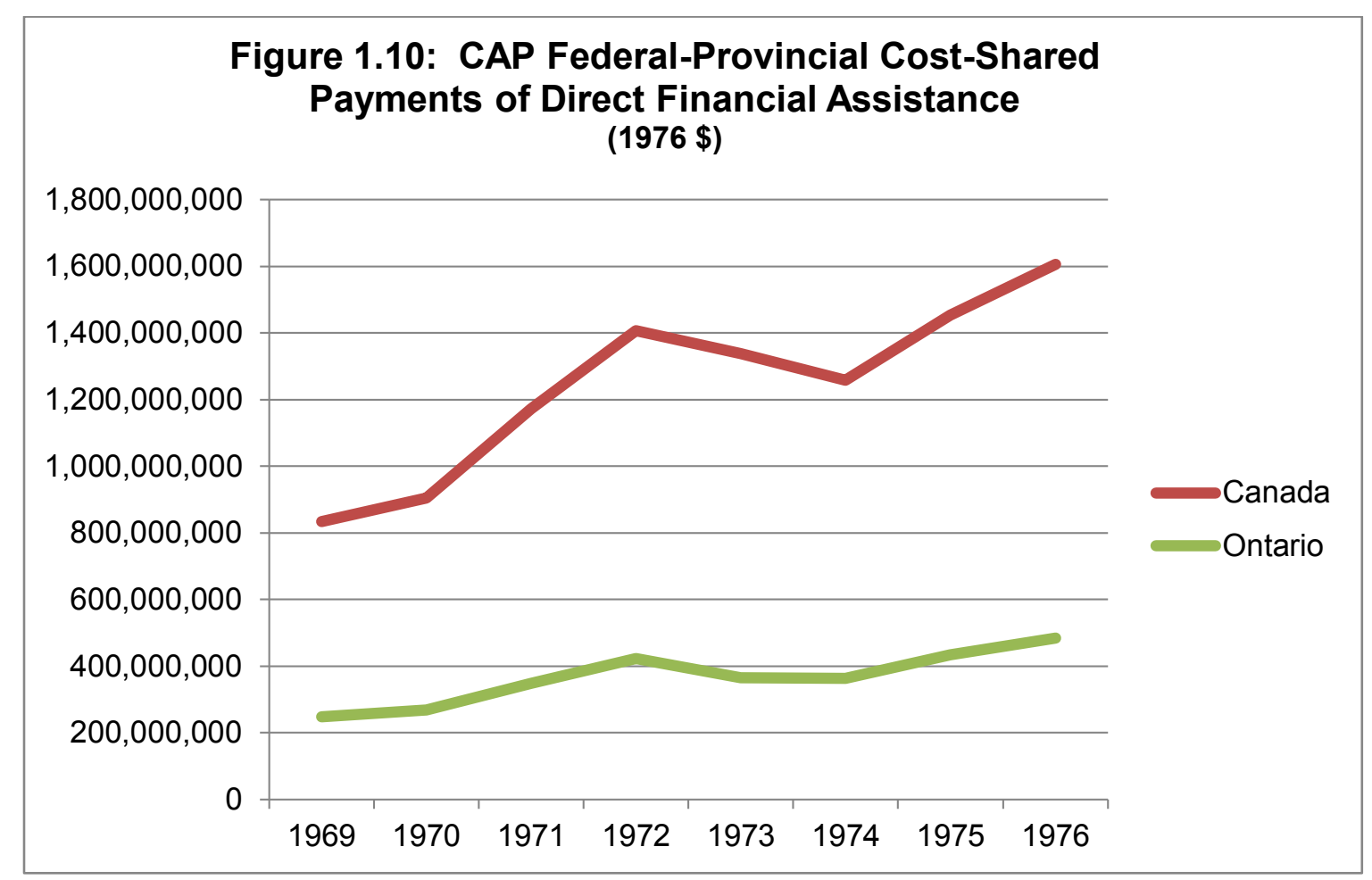

Source. Historical Statistics of Canada, Series C430-442.

Notes. Years are for fiscal years ending March 31. I have converted figures into 1976 dollars using the Consumer Price Index (Canada).

Between 1970 and 1976, federal-provincial cost-shared payments under CAP for “other welfare services and work activity" across Canada increased by 213 percent in real dollars. For Ontario, the increase was 237 percent (Historical Statistics of Canada, Series C469-481). 


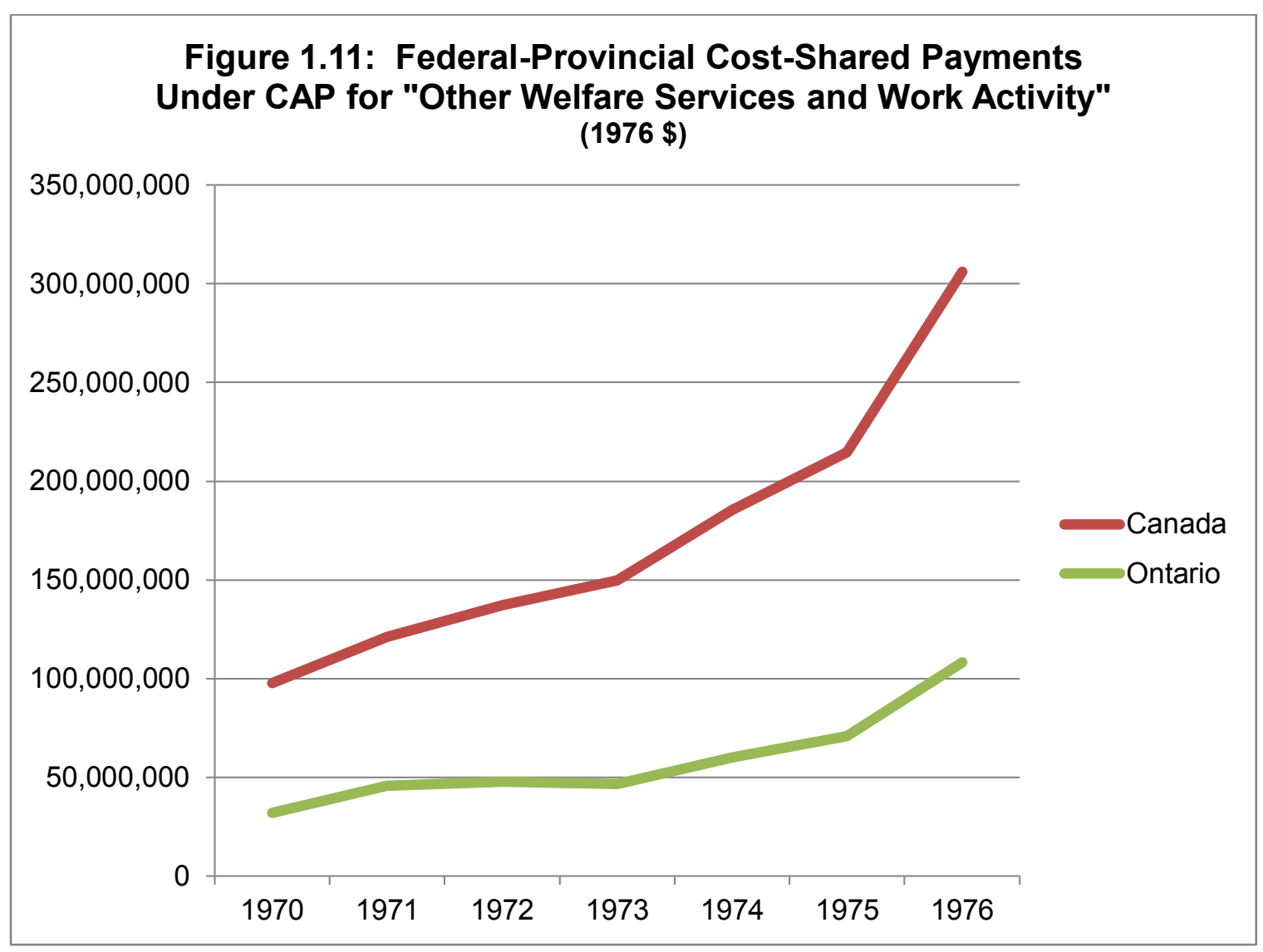

Source. Historical Statistics of Canada, Series C469-481.

Notes. Years are for fiscal years ending March 31. Figures are expressed in 1976 dollars, based on my conversions using the Consumer Price Index (Canada). 


\subsubsection{Brief Summation of Development of Ontario's Welfare System, 1965-1975}

By the mid-1960s, Canadian provinces had entered capitalism's so-called 'golden age.' Unemployment was low and government spending was growing very rapidly. The public mood was a confident one and many saw government as far more able than just a few decades earlier. The Canadian economy was expanding, and so was Ontario's civil service.

Against the backdrop of a robust economy, a minority government and the rising popularity of the NDP, the federal government introduced the CAP. And with optimism being felt across Canada as to the future of the Canadian economy and the importance of national unity, provinces (including Ontario) quickly accepted CAP's terms. This development, in which the state appeared to be favouring workers over capitalists, set the stage for a major restructuring of the manner in which social assistance was administered in Ontario.

The 1965-1975 period therefore witnessed the transition from a relatively ad hoc system of social assistance delivery in Ontario to one that was more organized. Canada's federal, provincial and Aboriginal governments began to accept that social assistance was here to stay and that it could be sustained via intergovernmental cooperation. 


\subsection{Conclusion}

In the early years of capitalism, the Canadian state provided very few social benefits to unemployed workers. In fact, the state was very undeveloped in general; very few people worked directly for it, and there were very few state expenditures compared with today. When the state did devote attention to unemployed workers in Canada, it was generally trying to induce them to work for capitalists — often through force. More important than worker well-being, from the vantage point of the state, was the day-to-day functioning of the capitalist system and its ongoing supply of eager, relatively healthy workers. Put differently, elected officials served the interests of owners of capital; workers, by contrast, were seen as commodities. Though this remained the case throughout the twentieth century, the extent to which the state favoured capital over labour changed in response to economic, policy and social developments.

In Canada, the Great Depression had a profound effect on how the state regarded capitalists and workers. Prior to the Great Depression, people without paid work were often regarded as lazy and deserving of their plight; but after the Great Depression, masses of people who had previously been employed were suddenly without work. Unemployment became seen as a national problem; a public appetite emerged for a concerted state response to joblessness. And so emerged a public relief system that would grow during the 1930s and help set the tone for further growth in ensuing decades.

World War II had a profound impact on the development of Canada's social welfare system. Within a very short amount of time, Canada's macroeconomic performance became unusually strong. Balance sheets of both the federal and Ontario governments were impressive, and relatively few persons were without work. Canada 
had seen the emergence of a spirit of solidarity during the war; and it was now relatively feasible — economically and politically_ for both the federal and provincial governments to become considerably more active in the provision of social support programs. Voters wanted a state that would favour workers more so than previously, and governments now had the fiscal capacity to act in ways that they did not prior to World War II. Canada's major political parties were reacting to the political winds by 'shifting left' and the federal bureaucracy was growing in size. That is, there was a strong perception among the Canadian public that the state had the capacity to do more for workers; elected officials read this mood, and the bureaucracy was directed to act in line with this shift. Organized labour provided strong political support to the $\mathrm{CCF}$ - and later the NDP — whose electoral support, in turn, prompted the other major political parties (both nationally and provincially) to shift their focus to assisting workers unable to secure employment. At various junctures in the lead-up to the mid-1960s, organized labour demonstrated a capacity to mobilize workers and embarrass government in between elections; organized labour also exerted strong influence during election campaigns. This had an important impact on what policies political parties campaigned on; it also had an important impact on what Ontario's income support system ultimately looked like. In effect, organized labour affected the way in which political parties played a mediating role in shaping the design and 'generosity' of Ontario's social assistance system.

This context helped bring about the CAP, which in turn gave strong encouragement to the Ontario government to increase both the scope and generosity of its social assistance system. From CAP's passage until the mid-1970s, annual payments for both social assistance and social services for Registered Indians saw very substantial 
increases. Likewise, annual payments for both GWA and FBA saw very substantial increases during the same period.

Under CAP, the federal government provided provincial and territorial governments with financial incentives to both broaden eligible criteria and increase benefit levels for welfare for 'employable' adults. In effect, the federal government was saying to provincial and territorial governments: "You set the parameters on who is eligible for welfare for employable adults; we'll cover half of the costs from here on in." What is more, any province or territory deciding not to broaden coverage for employable adults was in effect 'losing out' — indeed, federal taxes from residents in their own province/territory would be subsidizing employable social assistance recipients in other participating provinces/territories. Moreover, provincial governments were now agreeing (for the first time) to cost-share income assistance for adults with disabilities - meaning that provincial and territorial governments now had financial incentive to do less for 'unemployable' adults.

Social assistance for employable adults, in effect, had become less expensive for subnational governments to deliver; while income assistance programs for persons with disabilities had now become more expensive for subnational governments to deliver. These developments made it more tempting for provincial and territorial governments to implement well-funded welfare programs for adults who were expected to eventually find gainful employable. Thus, one could reasonably suggest that, with CAP, the federal state was siding more with unemployed workers than previously.

By the early-1960s, there was a higher degree of federal-provincial/territorial cost-sharing of social assistance for Indigenous persons, largely because First Nations 
people were moving from reserves to urban centres in large numbers. This would stand in contrast to the previous arrangement of social assistance for Indigenous persons (both on- and off-reserve) being viewed almost exclusively as a federal responsibility. To be sure, at roughly the same time that the federal government was agreeing to assist provincial and territorial governments with the cost of social assistance for the general population, provinces and territories were starting to fund some of the costs of social assistance for Indigenous persons. It would seem that in an era of strong economic growth - again, with the experiences of both the mass unemployment of the Great Depression and the collective struggle of the Second World War in recent memorysenior orders of government were showing increased cooperation as they jointly shared costs for social assistance.

Throughout the 1965-1975 period, the principle of less eligibility continued to guide policy development. At no point would any order of government implement social benefits for unemployed workers that were as high as what that same worker would earn in the labour market. Indeed, the financial incentive for jobless workers to both eagerly search for, and readily accept, paid work remained firmly intact. Although the work incentive may have diminished modestly with the introduction of higher social assistance benefit levels in Ontario during CAP's early years, the gap between what a worker would earn with full-time employment versus what they would receive not working remained considerable.

CAP brought in a sophisticated system for the state to manage the surplus labour population. The financial needs of this population would be attended to more than before; moreover, surplus workers gained more rights insofar as CAP brought in the right 
for a beneficiary to appeal a decision by a social assistance administrator. Nevertheless, surplus workers continued to be managed by the state and were still required to undertake job searches. Ontario may have increased social assistance benefit levels, and caseloads may have grown; but there was still considerable incentive for workers to continue serving capitalist interests. 


\subsubsection{Reference List}

Bacher, J. C., \& Hulchanski, J. D. (1987). Keeping warm and dry: The policy response to the struggle for shelter among Canada's homeless, 1900-1960. Urban History Review/Revue d'histoire urbaine, 16(2), 147-163.

Brown, R. C., \& Cook, R. (1974). Canada, 1896-1921: A nation transformed. Toronto: McClelland and Stewart.

Brushett, K. (2007). Where will the people go: Toronto's emergency housing program and the limits of Canadian social housing policy, 1944-1957. Journal of Urban History, 33, 375-399. doi: 10.1177/0096144206297148

Bryden, P. (1997). Planners and politicians: Liberal politics and social policy, 19571968. Montreal: McGill-Queen's University Press.

Campbell, R. M. C. (1987). Grand illusions: The politics of the Keynesian experience in Canada, 1945-1975. Peterborough: Broadview Press.

Canada. (1945). Proposals of the government of Canada. Presented to the DominionProvincial Conference on Reconstruction.

Canada. (1889). Report of the royal commission on the relations of labor and capital in Canada. Ottawa: Queen's Printer and Controller of Stationery.

Cassidy, H. M. (1932). Unemployment and relief in Ontario: 1929-1932. Toronto: J. M. Dent \& Sons.

de Schweinitz, K. (1961). England's road to social security. New York: Perpetua.

Department of Reconstruction. (1945). Employment and income with special reference to the initial period of reconstruction. Presented to Canada's Parliament by the Minister of Reconstruction.

Drummond, I. M. (1987). Progress without planning: The economic history of Ontario from confederation to the Second World War. Toronto: University of Toronto Press.

Dyck, R. (1976). The Canada assistance plan: the ultimate in cooperative federalism. Canadian Public Administration, 19(4), 587-602. 
Dyck, R. (1995). The Canada assistance plan: The Ultimate in co-operative federalism. In R. B. Blake \& J. Keshen (Eds.), Social welfare policy in Canada: Historical readings (pp. 326-39). Toronto: Copp Clark Ltd.

English, J. (2005). Pearson, Lester Bowles. In Dictionary of Canadian Biography (vol. 20). Retrieved from http://www.biographi.ca/en/bio/pearson_lester_bowles_20E.html

Esping-Andersen, G. (1990). The three worlds of welfare capitalism. Princeton, NJ: Princeton University Press.

Falvo, N. (2007, June). Addressing Canada's lack of affordable housing. Paper presented at the meeting of the Canadian Economics Association, Halifax. Retrieved from http://www.homelesshub.ca/library/addressing-canada\%E2\%80\%99s-lack-ofaffordable-housing-52646.aspx

Family Benefits Act: Regulation 287 under The Family Benefits Act. (1970). Revised Regulations of Ontario, 1970: A Revision and Consolidation of Regulations Published Under the Authority of the Regulations Revisions Act, 1968-69, Volume II. Toronto: William Kinmond, Queen's Printer and Publisher.

Finkel, A. (2006). Social policy and practice in Canada: A history. Waterloo, ON: Wilfrid Laurier University Press.

Friedländer, W. A. (1962). Individualism \& social welfare: An analysis of the system of social security and social welfare in France. New York: Free Press of Glencoe.

General Welfare Assistance Act: Regulations 383 under the General Welfare Assistance Act. (1970). Revised Regulations of Ontario, 1970: A Revision and Consolidation of Regulations Published Under the Authority of the Regulations Revisions Act, 1968-69, Volume II. Toronto: William Kinmond, Queen's Printer and Publisher.

General Welfare Assistance Amendment Act. (1967). An Act to Amend the General Welfare Assistance Act.

Globe and Mail. (1965, April 9). LaMarsh gives welfare plan to provinces, p. 37.

Globe and Mail. (1965, April 10). 10 welfare ministers approve Ottawa plan, p. 14.

Globe and Mail. (1965, April 20). Welfare conference to emphasize need, p. 1. 
Globe and Mail. (1965, July 20). Welfare merger in Canada Assistance Plan given unanimous endorsement by premiers, p. 9.

Grauer, A. E. (1939). Public assistance and social insurance: A study prepared for the Royal Commission on Dominion-Provincial Relations. Ottawa: J. O. Patenaude, I. S. O., Printer to the King's Most Excellent Majesty.

Guest, D. (1997). The emergence of social security in Canada ( $3^{\text {rd }}$ ed.). Vancouver: UBC Press.

Haddow, R. (1993). Poverty reform in Canada, 1958-1978: State and class influences on policy making. Montreal and Kingston: McGill-Queen's University Press.

Historical Statistics of Canada. (Series A339-349). Changes in the population through natural increase and migration, by province, by intercensal intervals, 1931 to 1976. Retrieved from http://www.statcan.gc.ca/pub/11-516-x/pdf/5500092-eng.pdf

Historical Statistics of Canada. (Series C144-156). Registered Indians, federal social assistance payments, for Canada and by province, fiscal years ending 31 March, 1968 to 1976. Retrieved from http://www.statcan.gc.ca/pub/11-516-x/pdf/5220013-eng.pdf

Historical Statistics of Canada. (Series C430-442). Canada Assistance Plan, federalprovincial cost-shared payments of direct financial assistance, for Canada and by province, fiscal years ending 31 March, 1969 to 1976. Retrieved from http://www.statcan.gc.ca/pub/11-516-x/pdf/5220013-eng.pdf

Historical Statistics of Canada. (Series C469-481). Federal-provincial cost-shared payments under the Canada Assistance Plan, for other welfare services and work activity, for Canada and by province, fiscal years ending 31 March, 1970 to 1976. Retrieved from http://www.statcan.gc.ca/pub/11-516-x/pdf/5220013-eng.pdf

Historical Statistics of Canada. (Series C495-507). Registered Indians, federal payments for social services, for Canada and by province, fiscal years ending 31 March, 1968 to 1975. Retrieved from http://www.statcan.gc.ca/pub/11-516-X/pdf/5220013-eng.pdf

Historical Statistics of Canada. (Series C577-582). Federal-provincial shareable expenditures of direct financial assistance to persons in Canada, fiscal years ending 31 March, 1961 to 1976. Retrieved from http://www.statcan.gc.ca/pub/11-516x/sectionc/4057749-eng.htm 
Historical Statistics of Canada. (Series E49-59). Average weekly wages and salaries, industrial composite, by province, 1939 to 1975. Retrieved from http:/www.statcan.gc.ca/pub/11-516-x/pdf/5500095-eng.pdf

Historical Statistics of Canada. (Series E190-197). Number of strikes and lockouts, employers and workers involved and time loss, Canada, 1901 to 1975. Retrieved from http://www.statcan.gc.ca/pub/11-516-x/pdf/5500095-eng.pdf

Historical Statistics of Canada. (Series R1-22). Selected principal statistics on the manufacturing industries, Canada, 1870 to 1975. Retrieved from http://www.statcan.gc.ca/pub/11-516-x/pdf/5220019-eng.pdf

Historical Statistics of Canada. (Series R84-94). Selected principal statistics on the manufacturing industries, Ontario, 1957 to 1975. Retrieved from http:/www.statcan.gc.ca/pub/11-516-x/pdf/5220019-eng.pdf

Historical Statistics of Canada. (Series R354-359). General statistics on the iron and steel products industries, 1948 Standard Industrial Classification, Canada, selected years, 1870 to 1959. Retrieved from http://www.statcan.gc.ca/pub/11-516x/pdf/5220019-eng.pdf

Historical Statistics of Canada. (Series R360-370). Selected principal statistics on the metal fabricating industries, Canada, 1957 to 1975. Retrieved from http:/www.statcan.gc.ca/pub/11-516-x/pdf/5220019-eng.pdf

Historical Statistics of Canada. (Series R439-449). Selected principal statistics on the petroleum and coal products industries, Canada, 1957 to 1975. Retrieved from http:/www.statcan.gc.ca/pub/11-516-x/pdf/5220019-eng.pdf

Historical Statistics of Canada. (Series H1-18). Federal government, budgetary revenue, by major source, 1867 to 1975. Retrieved from http://www.statcan.gc.ca/pub/11-516x/pdf/5500098-eng.pdf

Historical Statistics of Canada. (Series H124-135). Provincial governments, total net general revenue, by province, selected years, 1933 to 1969. Retrieved from http://www.statcan.gc.ca/pub/11-516-x/pdf/5500098-eng.pdf 
Historical Statistics of Canada. (Series H197-208). Provincial governments, total net general expenditure, by province, selected years, 1933 to 1969. Retrieved from http://www.statcan.gc.ca/pub/11-516-x/pdf/5500098-eng.pdf

Historical Statistics of Canada. (Series E175-177). Union membership in Canada, in total, as a percentage of non-agricultural paid workers, and union members with international affiliation, 1911 to 1975 . Retrieved from http:/www.statcan.gc.ca/pub/11-516-x/pdf/5500095-eng.pdf

Historical Statistics of Canada. (Series D491-497). Unemployment rates, by region, annual averages, 1946 to 1975. Retrieved from http://www.statcan.gc.ca/pub/11-516x/pdf/5500094-eng.pdf.

Hobsbawm, E. (2010). Age of Empire: 1875-1914. London: Hachette UK.

Horne, J. R. (2002). A social laboratory for modern France: the Musée social and the rise of the welfare state. Durham: Duke University Press.

Irving, A. (1987). From no poor law to the social assistance review: A history of social assistance in Ontario, 1791-1987 (Report No. RD44). Toronto: The Ontario Social Assistance Review.

Irving, A. (1989). “The Master Principle of Administering Relief': Jeremy Bentham, Sir Francis Bond Head and the establishment of the principle of less eligibility in Upper Canada. Canadian Review of Social Policy, 23, 13-18.

Jones, A., \& Rutman, L. (1981). In the children's aid: JJ Kelso and child welfare in Ontario. Toronto: University of Toronto Press.

Kealey, G. S. (1973). Canada investigates industrialism: The royal commission on the relations of labor and capital, 1889 (abridged). Toronto: University of Toronto Press.

LaMarsh, J. (1968). Memoirs of a bird in a gilded cage. Toronto: McClelland and Stewart Limited.

Little, M. (1998). 'No car, no radio, no liquor permit:' The moral regulation of single mothers in Ontario, 1920-1997. Toronto: Oxford University Press. 
MacDonald, D. C. (1998). The happy warrior: Political memoirs ( $2^{\text {nd }}$ ed.). Toronto: Dundurn Press.

Marx, K. (1976). Wage-labour and capital: Value, price and profit. New York: International Publishers.

McDougall, A. K. (1986). John P. Robarts: His life and government. Toronto: University of Toronto Press.

Morton, D. (1999). Working people: An illustrated history of the Canadian labour movement. Montreal: McGill-Queen's Press.

Moscovitch, A. (1988). Chapter 10: The Canada assistance plan: A twenty year assessment, 1966-1986. In K. A. Graham (Ed.), How Ottawa Spends, 1988/89: The conservatives heading into the stretch (269-307). Don Mills: Carleton University Press.

Moscovitch, A. (1996). Canada Health and Social Transfer: What was lost? Canadian Review of Social Policy, 37, 66-75.

Moscovitch, A., \& Webster, A. (1995). Social Assistance and Aboriginal People: A Discussion Paper Prepared for Royal Commission on Aboriginal Peoples.

Naiman, J. (1997). How societies work: Class, power and change in a Canadian context. Toronto: Irwin Publishing.

Newman, P. C. (1965, April 6). The throne speech shows fear of NDP. Toronto Daily Star, p. 7.

Novick, R. M. (1980). Chapter 20: Social policy: The search for a provincial framework. In D. C. MacDonald (Ed.), Government and politics of Ontario $\left(2^{\text {nd }}\right.$ ed.) (382-405). Toronto: Van Nostrand Reinhold Ltd.

Ontario Non-Profit Housing Association. (Undated). Timeline: History of social housing in Ontario 1945 - 2001. Retrieved from http://www.onpha.on.ca

Panitch, L. (1977). The role and nature of the Canadian state. In L. Panitch (Ed.), The Canadian state: Political economy and political power (pp. 3-27). Toronto: University of Toronto Press.

Piven, F. F. (1999). Welfare and work. In M. Gwendolyn (Ed.), Whose welfare? (pp. 83-99). Ithaca: Cornell University Press. 
Piven, F. F., \& Cloward, R. A. (1993). Regulating the poor: The Functions of public welfare. New York: Vintage Books.

Polanyi, K. (2001). The great transformation: The political and economic origins of our time. Boston: Beacon Press.

Rae, J. (2014). The 1965 agreement: Overview \& focus on child welfare [PowerPoint slides]. Retrieved from http://www.oktlaw.com/wp-content/uploads/2014/02/jfr1965Agreement.pdf

Rice, J. J., \& Prince, M. J. (2013). Changing politics of Canadian social policy (2 ${ }^{\text {nd }}$ ed.). Toronto: University of Toronto Press.

Rooke, P. T., \& Schnell, R. L. (1987). No bleeding heart: Charlotte Whitton, a feminist on the right. Vancouver: UBC Press.

Rose, A. (1980). Canadian housing policies (1935-1980). Toronto: Butterworths.

Schull, J. (1978). Ontario since 1867. Toronto: McClelland and Stewart.

Seccareccia, M. (2012, March). Is full employment an achievable goal? Paper presented at Policy Choices: Austerity, Inequality, or Full Employment?, Sudbury, ON.

Sewell, J. (1994). Houses and homes: Housing for Canadians. Toronto: James Lorimar \& Company.

Shackleton, D. F. (1988). Ishbel and the empire: a biography of Lady Aberdeen. Toronto: Dundurn Group.

Social Planning Council of Metropolitan Toronto and the Ontario Welfare Council. (1977). Social allowances in Ontario: An historical analysis of general welfare assistance and family benefits.

SPCMT \& OWC. See Social Planning Council of Metropolitan Toronto and the Ontario Welfare Council.

Stanford, J. (2008). Economics for everyone: A short guide to the economics of capitalism. Winnipeg: Fernwood Publishing.

Stapleton, J. (2007). A history of First Nations social services arrangements within MCSS and its predecessors [PowerPoint slides]. Retrieved from 
http://openpolicyontario.com/wordpress/wp-content/uploads/2012/02/History-of-FirstNations.pdf

Stapleton, J. (2012). A difficult puzzle: Social assistance caseloads in the great depression and three major post-war recessions [PowerPoint slides]. Retrieved from http://openpolicyontario.com/wordpress/wp-content/uploads/2012/02/A-DifficultPuzzlemay32012.pdf

Stapleton, J., \& Laframboise, C. (2007). Coming of age in a man's world: The life, times and wisdom of Dorothea Crittenden, Canada's first deputy minister. Unpublished manuscript. Retrieved from http://openpolicyontario.com/wordpress/wpcontent/uploads/2012/02/Interview_Crittenden_1.pdf

Stevenson, G. (1999). Federalism and intergovernmental relations. In M. Whittington \& G. Williams (Eds.), Canadian politics in the $21^{\text {st }}$ century ( $5^{\text {th }}$ ed., pp. 79-104). Scarborough: Nelson.

Stevenson, G. (2004). Unfulfilled union: Canadian federalism and national unity. Montreal: McGill-Queen's University Press.

Struthers, J. (1987). Shadows from the thirties: The federal government and unemployment assistance, 1941-1956. In J. S. Ismael (Ed.), The Canadian welfare state: Evolution and transition (pp. 3-32). Edmonton: University of Alberta Press.

Struthers, J. (1991). How much is enough? Creating a social minimum in Ontario, 193044. Canadian Historical Review, 72(1), 39-83.

Struthers, J. (1994). The limits of affluence: Welfare in Ontario, 1920-1970. Toronto: University of Toronto Press.

Swadron, B. B. (1972). Report of the Task Force on Employment Opportunities for Welfare Recipients. A report to the Honourable Rene Brunelle, Ontario Minister of Social and Family Services.

Sweezy, P. M. (1970). The theory of capitalist development. New York: Monthly Review Press.

TAP Associates Ltd. (1979). A starving man doesn't argue: A review of community social services to Indians in Ontario. A report prepared for the Tripartite Social Services Review Committee by Technical Assistance and Planning Associates Limited. 
Therborn, G. (1978). What does the ruling class do when it rules? State apparatuses and state power under feudalism, capitalism and socialism. London: NLB.

Toronto Daily Star. (1965, April 6). Speech from the throne draws both praise and scepticism, p. 4.

White, R. (1985). Ontario: 1610-1985. Toronto: Dundurn Press.

Williams, C. J. (1984). Decades of service: A history of the Ontario Ministry of Community and Social Services, 1930-1980. Toronto: The Ministry of Community and Social Services.

Yaremko, J. (1970). A brief prepared for the special senate committee on poverty. 


\section{Appendix 1.1}

\section{Table 1.5}

Relief Disbursements by Financial Arrangement, 1931-1937

(All Provinces, Millions of Dollars)

\begin{tabular}{|c|c|c|c|c|c|c|c|c|}
\hline & 1931 & 1932 & 1933 & 1934 & 1935 & 1936 & 1937 & $\begin{array}{l}1931- \\
1937 \\
\text { Total }\end{array}$ \\
\hline $\begin{array}{c}\text { Dominion } \\
\text { Share }\end{array}$ & 3 & 33 & 34 & 28 & 43 & 41 & 52 & 234 \\
\hline $\begin{array}{l}\text { Dominion } \\
\text { Loans to } \\
\text { Provinces }\end{array}$ & N.A. & 11 & 15 & 9 & 21 & 32 & 14 & 102 \\
\hline $\begin{array}{c}\text { Provincial } \\
\text { Share }\end{array}$ & 9 & 39 & 39 & 49 & 75 & 70 & 52 & 333 \\
\hline $\begin{array}{c}\text { Provincial } \\
\text { Loans to } \\
\text { Municipalities }\end{array}$ & N.A. & 1 & 2 & 2 & 3 & 2 & N.A. & 10 \\
\hline $\begin{array}{c}\text { Municipal } \\
\text { Share }\end{array}$ & 9 & 21 & 21 & 24 & 24 & 24 & 23 & 146 \\
\hline Total & 21 & 93 & 94 & 101 & 142 & 135 & 127 & 713 \\
\hline
\end{tabular}

Note. The above is taken from Table 3 of Grauer (1939), found on page 14. Figures are expressed in millions of dollars. Each year's figure is for fiscal year ending March 31. 


\section{Appendix 1.2}

\section{Table 1.6}

Relief Disbursements by Level of Government, 1931-1937 (Ontario, Millions of Dollars)

\begin{tabular}{lcccccccc}
\hline & 1931 & 1932 & 1933 & 1934 & 1935 & 1936 & 1937 & $\begin{array}{c}1931- \\
1937 \\
\text { Total }\end{array}$ \\
\hline Dominion Share & 1.2 & 9.4 & 9.5 & 11.9 & 15.5 & 15.6 & 15.1 & 78.2 \\
\hline $\begin{array}{l}\text { Provincial } \\
\text { Share }\end{array}$ & 2.1 & 8.7 & 13.7 & 23.1 & 38.2 & 30.7 & 15.8 & 132.3 \\
\hline Municipal Share & 2.8 & 7.7 & 8.2 & 7.7 & 8.6 & 8.2 & 7.1 & 50.3 \\
\hline & & & & & & & & \\
\hline Total & 6.1 & 25.8 & 31.4 & 42.7 & 62.3 & 54.5 & 38.0 & 260.8 \\
\hline
\end{tabular}

Note. The above is taken from Table 3 of Grauer (1939), found on page 14. Figures are expressed in millions of dollars. Each year's figure is for fiscal year ending March 31. 
Appendix 1.3

Unemployment Rate, Canada and Ontario, 1946-1975

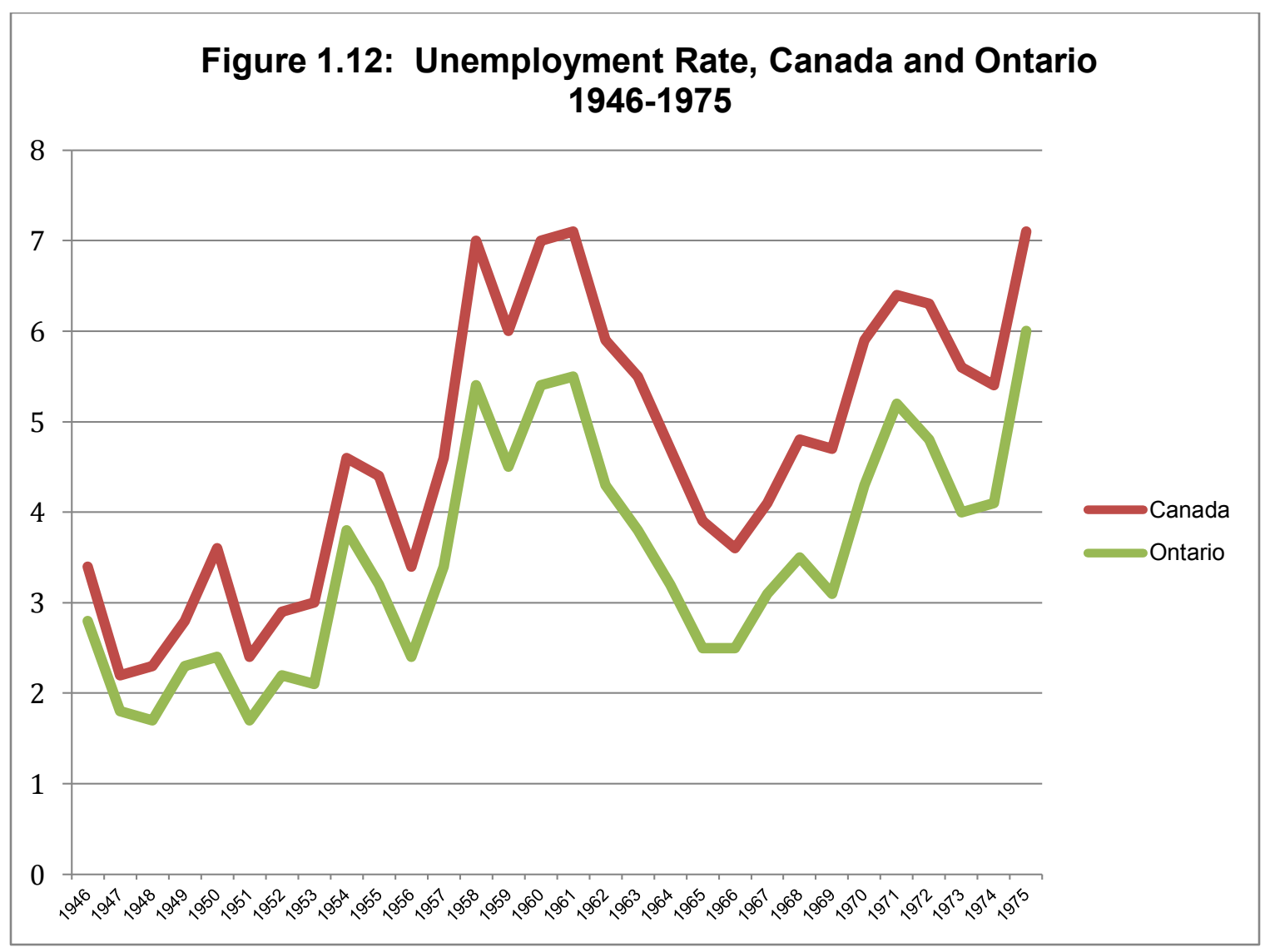

Source. Historical Statistics of Canada. (Series D491-497). Unemployment rates, by region, annual averages, 1946 to 1975. Retrieved from http://www.statcan.gc.ca/pub/11-516-x/pdf/5500094-eng.pdf

Note. All figures exclude the Yukon Territory, the Northwest Territories and Indians on reserves. 


\section{Essay 2: Monthly Purchases of Social Assistance Recipients}




\section{Introduction}

A single adult on welfare in Ontario receives approximately $\$ 7,000$ annually in SA benefits; and low income is known to be associated with both poor health (Marmot, 2002) and lower food expenditures, including fewer purchases of milk, fruits and vegetables (Kirkpatrick \& Tarasuk, 2003; see also Vozoris \& Tarasuk, 2003). Ricciuto, Tarasuk, and Yatchew (2006) argue that there is a direct relationship between a household's income level and its purchase of foods from all groups, especially fruit, vegetables and milk. This relationship is especially strong when a household's annual income is below $\$ 15,000$. Adults in food-insecure households have a higher prevalence of nutrient inadequacy (Kirkpatrick, 2008), and poor nutrition is known to predispose individuals to various health problems, including hypertension, diabetes and some types of cancer (Tarasuk, 2009). However, less is known about the causal associations, and virtually nothing is known about the health implications of a substantial increase in monthly income to the budgets of very low-income households.

Virtually no research has been undertaken on how SA recipients in Ontario (or anywhere else) spend their benefits or how they would spend increased benefits. No research at all has been done on how increases in benefit levels might affect a recipient's living conditions, such as their health outcomes. Research on the types of expenditures made by SA recipients is therefore worthwhile, especially research with a focus on singles without dependents-the fastest-growing SA family type in Ontario (Lankin \& Sheikh, 2011). Such research could allow policymakers to make more informed decisions about optimal SA benefit levels; it could also allow for more fruitful debate among stakeholder groups. 
The present research follows singles on SA as they move from collecting lastresort SA (through the Ontario Works [OW] program) to disability benefits (through the Ontario Disability Support Program [ODSP]). One advantage of looking at this particular subsample of individuals is that single, unattached adults without dependents see the greatest percentage increase in monthly income of any household type upon transitioning from OW to ODSP. Indeed, when these interviews took place, such an individual would see their monthly benefits increase from $\$ 585$ to $\$ 1,042$, representing a 78 percent increase. ${ }^{29}$ This would therefore allow for a higher likelihood of there being an observable difference in monthly purchases.

This essay seeks to lay both the theoretical and methodological foundation for future research on the budgeting of SA recipients; it is an exploratory study seeking to demonstrate the feasibility of a larger study. In that vein, it generates hypotheses that can be tested in a future study involving a larger sample size. In addition, it establishes a method by which knowledge gaps on several fronts can be filled. The first such gap involves the monthly budgets of very low-income households, especially single men on SA. Second, the research examines the impact of a significant increase in monthly income on the monthly purchases of very low-income individuals. The third area involves the change in health outcomes resulting from a significant increase in income.

It begins by summarizing what is currently known about the budgeting of lowincome households in North America; this will include a brief look at survey work currently done on household spending by Statistics Canada. It will then review Edin and Lein's pioneering research on budgets of low-income single mothers (Edin \& Lein,

\footnotetext{
${ }^{29}$ This report was discussed in the introductory chapter of the present dissertation.
} 
1997); their methodology and major findings will be discussed. This will be followed by a consideration of budgeting research that has followed Edin and Lein's methods.

I will then discuss the essence of this essay, namely, my own research on budgeting that was undertaken for this dissertation. I will discuss how I gained access to SA recipients in Toronto and how I worked with City of Toronto officials to contact city residents receiving Ontario Works to determine their interest in participating in this research project. I will discuss how I went about interviewing clients about their budgets and how I gained their trust. I will discuss how many times I interviewed them, what I asked them, what I found, and what conclusions I have since drawn. Finally, I will discuss implications for future research.

\section{Budget Literature}

In the present study, "budget" includes four things: 1) a person's official monthly income (including SA benefits and any income earned from gainful employment and disclosed to SA officials); 2) a person's unofficial income (including undeclared work and gifts from family or friends); 3) a person's spending; and 4) bartering. A small body of research on budgets of very low-income households does exist, with Edin and Lein (1997) having been considered ground-breaking at the time. Most research on budgets of very low-income households has been confined to households with children, and the majority of North American research has focused on the United States. The research reported here may be the only Canadian study on very low-income budgeting, and likely the only one to examine reactions to a changed income among very low-income households. It is the first study to look at the effect of a changed income on a specific type of SA recipients. 
Though this research attempts to fill an important gap, some research on household budgets is already in existence. This section provides a broad overview of the already-existing research. It will start by discussing Statistics Canada's Survey of Household Spending. This will be followed by a brief summary of Edin and Lein's findings, followed by a look at research done by others who use Edin and Lein's methods.

\section{Survey of Household Spending}

Statistics Canada's Survey of Household Spending (SHS) asks a sample of Canadian households detailed information about their budgets. This voluntary survey includes both a questionnaire and a daily expenditure diary that is completed by participating households over a two-week period. Income information about participating households is obtained from individual tax returns. The 2013 survey had a sample size of approximately 17,000 Canadian households - all of whom completed the questionnaire and half of whom completed the diary. The SHS provides a breakdown of household spending according to income quintiles, finding that households in the lowest income quintile pay a higher proportion of their budget on food and shelter than do households from the other quintiles. However, the SHS does not provide a specific breakdown for households on SA or for specific household types on SA (Statistics Canada, 2015). Because it is a cross-sectional survey, it certainly does not provide information on budget changes for specific SA household types who have experienced an increase in monthly income, and it makes no attempt to assess changes in health outcomes following changes in monthly income. 


\section{Edin and Lein, 1997}

Edin and Lein (1997) studied 379 low-income single mothers in the mid-1990s.

Approximately half of them received social assistance. They drew their sample from four different cities, namely Chicago, Boston, San Antonio and Charleston (Edin \& Lein, 1997). Informal, semi-structured interviews were conducted. In the authors' words, because of the sensitive nature of the subject,

...we recruited mothers with the assistance of a wide variety of trusted community residents, including members of neighbourhood block groups, housing authority residents' councils, churches, local community organizations, and local charities that the community held in high regard (Edin \& Lein, 1997, p. 12).

Table 2.1 provides a summary of Edin and Lein's findings. Table 2.1 provides a summary of expenses by general category, reported income by category and reported sources of income. Findings are reported in both dollar terms and as a percentage of each recipient's monthly budget. Edin and Lein (1997) did not study the impact of income changes on health outcomes. 
Table 2.1

Monthly Spending by Mothers on Social Assistance (Edin and Lein, 1997)

\begin{tabular}{|c|c|c|}
\hline Variable & Average Income & Percentage of Budget \\
\hline Total expenses & $\$ 876$ & $100 \%$ \\
\hline Housing costs & 213 & 24 \\
\hline Food costs & 262 & 30 \\
\hline Other "necessities" & 336 & 39 \\
\hline "Nonessentials" & 64 & 7 \\
\hline Total income & $\$ 883$ & $100 \%$ \\
\hline Welfare benefits & 565 & 64 \\
\hline AFDC & 307 & 35 \\
\hline Food stamps & 222 & 25 \\
\hline $\mathrm{SSI}^{\mathrm{a}}$ & 36 & 4 \\
\hline EITC $^{b}$ & 3 & 2 \\
\hline Work-based & 128 & 15 \\
\hline strategies & 19 & 2 \\
\hline Reported work & 90 & 10 \\
\hline Unreported work & 19 & 2 \\
\hline Underground work & & \\
\hline $\begin{array}{l}\text { Network-based } \\
\text { strategies }\end{array}$ & 151 & 17 \\
\hline Family and friends & 62 & 7 \\
\hline Men & 95 & 11 \\
\hline Boyfriends & 56 & 6 \\
\hline Absent fathers & 39 & 4 \\
\hline Covert system & 33 & 4 \\
\hline Formal system & 7 & 1 \\
\hline $\begin{array}{l}\text { Agency-based } \\
\text { strategies }\end{array}$ & 37 & 4 \\
\hline \multicolumn{3}{|c|}{$\begin{array}{l}\text { Note. Adapted from Edin and Lein (1997, p. 44). This is a modified version of Table 2-6. According to } \\
\text { Edin and Lein, the above "income-generating strategies do not include in-kind contributions or } \\
\text { purchasing goods illegally because these figures were difficult to estimate." Also, numbers do not 'add } \\
\text { up' due to rounding, and some of percentages exceed } 100 \text { because "some mothers engaged in more } \\
\text { than one strategy" (Edin \& Lein, 1997, p. 44). } \\
\text { aSSI refers to Supplementary Security Income, available to low-income Americans who are either } 65 \\
\text { years of age or older, or who are disabled. For more on the SSI program, see: } \\
\text { http://www.ssa.gov/ssi/text-eligibility-ussi.htm. "EITC refers to the Earned Income Tax Credit, which is } \\
\text { a cash supplement an individual can receive once they have "established a moderate attachment to the } \\
\text { workforce" (Drummond \& Manning, 2005, p. 28). }\end{array}$} \\
\hline
\end{tabular}




\section{Other Budgeting Research}

Several budgeting studies — each with a unique methodological approach — have built on Edin and Lein's research, but none focus on single adults without dependents. Lugo-Gil and Yoshikawa (2006), studying a sample of low-income mothers in New York City, found their research participants to spend 21 percent of their budgets on food, 19 percent on rent, 13 percent on "car related expenses" and 10 percent on savings (LugoGil \& Yoshikawa, 2006). Mistry, Lowe, Benner, and Chien (2008) studied low-income mothers in Milwaukee, but did not provide quantitative estimates of the percentage of household budgets spent on different items (Mistry et al., 2008).

Mendenhal, Edin, Crowley, Sykes, Tach, Kriz, and Kling (2012) studied parents who receive Earned Income Tax Credit (EITC) refunds of at least $\$ 1,000$ and who reside in one of two metropolitan areas — namely Boston and the Champaign-Urbana metro area of central Illinois. They find that 46 percent of EITC refunds for their sample are spent on "current consumption," 36 percent on "bills and debt," and 19 percent on "asset building” (Mendenhall et al., 2012).

The present essay will now discuss a series of interviews with SA recipients about what their budgets look like each month. Some interviews took place when individuals were receiving OW benefits, others when individuals were receiving significantly-higher ODSP benefits. 


\subsection{Methods}

This section outlines the methods used in this research. After discussing the research objectives, it will discuss the invaluable partnership that was forged between the researcher and Project HOPE. It will then provide rationale for: seeking to interview each interview subject as many as six times; interviewing only men; and undertaking qualitative interviews. It will also discuss the pre-screening process, interview organization (and implementation) and the intended analysis of results. Finally, it will discuss challenges with respect to Research Ethics Boards (REBs).

\subsubsection{Research Objective}

This essay is an empirically-grounded, hypothesis-generating exercise. The research attempts to further understand the relationship between income, health and nutrition among very low-income men. The study seeks to lay the theoretical and methodological groundwork for further research seeking: 1) to document how very lowincome single men spend their money each month;2) to document the health status of very low-income single men; and 3) to examine the extent to which increases in income may influence monthly expenditures. The sample is drawn from OW recipients specifically, 10 single, unattached men without dependents, who have been deemed by caseworkers as likely becoming eligible to receive disability benefits once a completed application is submitted. In-depth interviews took place with individuals over an 18month period. Between four and six interviews took place with each individual, lasting approximately one hour each. Interviewees were asked what they spend their money on each month. They were also asked about health status, using the SF-36v2 health survey (to be discussed below). 
It was impossible to know in advance which interview subjects-or how many-would make the transition from OW to ODSP. The transition depends in part on which interview subjects successfully put together a completed application for review by ODSP's Disability Adjudication Unit (DAU), and on the DAU's eventual decision. Based on the past successes of Project HOPE (to be discussed below), I expected that approximately half of the interview subjects would make the transition during the 18month study period.

The transition to ODSP is a central focus of the study. As will be discussed below, the pool of interview subjects was recruited from Project HOPE (as opposed to the City of Toronto's much larger pool of OW clients) precisely because many were about to make a transition to ODSP. Moreover, one of the reasons for up to six, one-hour interviews over such a lengthy period was to allow for the interview subject to settle into a revised budgeting style as they adapted to an increase in monthly income.

\subsubsection{Partnership With Project HOPE}

For recruitment purposes, cooperation was sought from officials with Project HOPE, whose mandate is to facilitate both the application for-and approval of-ODSP benefits for marginally-housed individuals in Toronto. ${ }^{30}$ HOPE, operating out of four downtown offices, provides intensive case management to marginally-housed clients who receive OW. Between July 2007 and September 2009, 398 homeless clients had enrolled

\footnotetext{
${ }^{30}$ HOPE was created by Toronto Employment and Social Services (TESS) in 2007, in response to reports from both the Auditor General of Ontario and Street Health (a Toronto-based community agency) that identified multiple barriers encountered by homeless persons when trying to access ODSP.
} 
in HOPE, roughly half of whom had subsequently been granted ODSP benefits, and roughly one-third of whom had been assisted in obtaining housing (Hainsworth, 2009).

The researcher sent the Manager an introductory e-mail that included a brief (onepage) description of the proposed research. A meeting ensued with the Manager and her Director, with a request for a longer (six-page) description of the proposed research (including specific information on how the proposed research could potentially result in policy changes). ${ }^{31}$ The researcher indicated that all 10 men in the sample must be able to communicate orally in English and must be between the ages of 18 and 64; they must also be single with no dependents. Several in-person meetings were eventually held between the researcher and Toronto Employment and Social Services (TESS) officials. Subsequently, TESS officials, consistent with the division's protocols for supporting research into important social assistance policy and program issues, assisted the researcher to recruit participants. TESS caseworkers also helped develop recruitment approaches.

Thus, men were recruited who: 1) were currently enrolled in HOPE; 2) were single; and 3) had no dependents. All of the interview subjects were to be on OW when the interviews began. All interviews were conducted in English; thus, participants had to be comfortable speaking English. Ten men were initially interviewed, and each participant was offered an opportunity to be interviewed up to six times within an 18month time frame.

Participants were recruited with the help of HOPE staff, who operate out of four TESS locations: Downtown Toronto Social Services (111 Wellesley Street East); Metro

\footnotetext{
${ }^{31}$ Both the one-page and six-page descriptions can be found in Appendices A and B respectively.
} 
Hall Social Services (55 John Street); East Toronto Social Services (1631 Queen Street East); and Scarborough West Social Services (1225 Kennedy Road). Caseworkers distributed flyers, prepared by the researcher, to eligible clients. The flyers encouraged potential participants to call the researcher at a telephone number provided, where they were further screened for eligibility by the researcher. No information about HOPE cases was shared by TESS staff with the researcher, nor will any information collected by the researcher about study participants be shared with TESS. Participation in the study was completely voluntary.

TESS officials were interested in the overall findings of the research project, as the approach taken in this study may provide insights into issues about which little is known at this point, as noted in the introduction to this paper.

\subsubsection{Why Six Interviews per Person?}

To enhance the much-needed openness and rapport-building between the interviewee and the interviewer, up to six interviews were conducted with each participant. Edin and Lein (1997) identify two main reasons for multiple interviews when interviewing low-income individuals about their monthly purchases:

First, [respondents] who were unclear about their expenditures the first time we interviewed them could keep careful track of what they spent between interviews and give a more precise accounting of their budget the second or third time around. Second, multiple contacts gave the interviewers a chance to double- and triple-check budget information, probing for more information when budgets were not in balance or did not make sense (Edin \& Lein, 1997, p. 14).

Further, men could be interviewed at different stages in their receipt of benefits both when receiving OW benefits (\$585/month) and when receiving ODSP benefits (\$1,042/month) - in light of the significant increase in monthly income that comes with 
ODSP. This is in keeping with the following statement made by Dunn (2012, p. 40) when encouraging researchers to undertake in-depth research with a small sample size: "Experimentation is especially valuable because a system behaves differently when it is perturbed than when it is stable, and this perturbation can reveal dormant causal mechanisms in a system." For example, one interview subject in the present study reported curbing his purchases of illicit drugs and alcohol after transitioning to ODSP on the grounds that greater income had given him reason to believe that it was now "time for a change." This will be discussed in the Results section below.

\subsubsection{Why Just Men?}

The study focuses on men on SA between the ages of 18 and 64. There are five main reasons for focusing on men:

1. As will be discussed below, Carleton University's REB expressed a greater comfort level with the researcher interviewing men rather than women (given that the researcher is male).

2. The study aimed to generate hypotheses, and this can more easily be done with a homogenous group.

3. Edin and Lein's research focuses exclusively on women, and little (if any) research on budgeting since has focused on men. This makes the budgets of very low-income men a relatively unexplored area.

4. Almost two-thirds of singles on OW are men (Lankin \& Sheikh, 2011).

5. The researcher has worked almost exclusively with men in his decadelong career as a community worker, meaning it is a population about which he has knowledge and with whom he has a good rapport. 


\subsubsection{Rationale for Qualitative Interviews}

Dunn (2012) encourages researchers to move "beyond the simple recognition that something produces some change, to understanding what it is about the object(s) that enables it (them) to do this" (Dunn, 2012, p. 30). Citing Sayer (1992), he notes that "qualitative information is needed on the nature of the objects involved and not merely more quantitative data on empirical associations" (Dunn, 2012, p. 31). Further, Dunn encourages research that

...asks questions about how a process works in a small number of cases [emphasis added], often with identifiable people and/or institutions, by identifying substantial relations of connection between such factors as the reasons people give for their actions, their biographies and contingent factors (Dunn, 2012, p. 35).

Relating such methodological considerations to the general subject area of the present essay, Carpiano, Link, and Phelan (2010) argue that

...progress in discovering the mechanisms of fundamental causality [between social class and health outcomes] hinges on carefully specified theoretical considerations, a variety of qualitative and quantitative methodological approaches, and avoidance of a risk-factor approach that merely seeks to test statistical associations between social class indicators and health outcomes (Carpiano et al., 2010, p. 256).

With the above considerations in mind, in-depth, semi-structured interviews were used in the present study. One-on-one interviews were conducted face-to-face. It has been argued by McKague and Verhoef (2003) that such a methodology is helpful in carrying out in-depth interviews with people with limited power and social status. Oneon-one interviews also allow interview subjects to freely discuss issues that could be stigmatizing (and inappropriate for a group setting). Further, individual interviews provided the researcher with an opportunity to probe when topics specific to the individual in question were unclear (Ritchie \& Lewis, 2003). 
Though a sample size of 10 is small, this research had only pilot funding, meaning that a larger sample was not possible under the circumstances. Each interview subject who underwent six full interviews required the equivalent of $\$ 180$ as an honorarium. Also, each time the researcher travelled from Ottawa to Toronto for interviews, travel expenses were incurred. While the researcher hopes to interview a much larger sample in future (with the aid of funding from a major granting council) 10 interview subjects are sufficient for hypothesis generation and assisted in piloting this 'made-in-Canada' version of Edin and Lein's methodology, focusing exclusively on singles on OW. Moreover, studying singles on SA without dependents offered the researcher a unique opportunity that researchers in the United States generally do not have. Indeed, in the United States, where most research on this topic has been done, "[v]irtually no cash benefits are available to childless working-age adults unless they are disabled..." (Edin \& Lein, 1997, p. 34).

\subsubsection{Pre-Screening}

As stated above, before the initial telephone conversation, an effort was made to ensure that each participant was an eligible candidate. TESS caseworkers initially provided flyers inviting prospective candidates to take part in the research. An individual was not selected if he was: 1) considered by law to be "incapable" of providing consent; 2) living with a spouse; 3 ) had dependents; 3 ) was under the age of 18 ; or 4) was over the age of 65 . 


\subsubsection{Interview Organization}

On receiving phone calls from interested participants, eligibility was confirmed by the researcher, as was the purpose of the study; the process of informed consent was also completed at this time. The researcher explained that if the individual agreed to be interviewed, nothing from the interview would be divulged to SA officials, and that the name of the interview subject would not appear beside their answers in his notes. The researcher explained remuneration and told the individual that there would be up to six interviews over an 18-month period. When a participant indicated that he would like to be interviewed, a time and place was arranged that was convenient for the participanttypically a coffee shop. Each individual was asked for a telephone number, should there be a need to contact them before the interview (in the event of illness, for example). The researcher also offered to mail them sample questions.

The researcher used the 'ask, wait and probe' principle (Taylor \& Bogdan, 1998). An interview guide was used, allowing the researcher to loosely define the research area (Britten, 1995). In Kvale's (1996) words: “The interviewer leads the subject towards certain themes [e.g. across multiple interviewees], but not to certain opinions about these themes" (Kvale, 1996, p. 34). The researcher often probed after initial answers, encouraging interview subjects to expand on their responses. In keeping with Edin and Lein's (1997) methodology, the questions were "informal and unstructured." The initial questions served as a means of collecting basic information about the participant's living situation (i.e. How do you like your neighbourhood?) and monthly spending on such things as rent, food, transportation and communication. By the second interview, the SF- 
36v2 health survey was used as a means to assess health status. ${ }^{32}$ This aspect of the research was more structured. The expected duration of each interview was 60 minutes. To encourage participants to speak more freely, interviews were neither audio- nor videorecorded; rather, notes were taken by hand.

In order to see how interview subjects spend their money each month, the researcher asked questions such as "How much do you pay per month in rent?" and "Roughly how much money do you spend per month on banking fees?" In order to document monies used to purchase fruits and vegetables, the researcher asked questions such as "Roughly how much money per month do you spend on food?" and "Roughly how much money per month do you spend on fruit and vegetables?" To document health status, the SF-36v2 health survey was administered on as many as two occasions over the course of the 18-month study. To examine the extent to which increases in income influence monthly expenditures, the interview guide was administered both pre-transition to ODSP, and post-transition to ODSP (where possible). And, to document the barriers to acquiring and consuming fruits and vegetables, the researcher asked questions such as "What would you say is your biggest problem when it comes to food purchases?" and "What do you think it would take for you to double your monthly consumption of fruits and vegetables?" For details, see Interview Guide in Appendix 2.3.

Self-rated health is considered a reliable measure of health (Lundberg \& Manderbacka 1996; see also Shields \& Shooshatari, 2001). The SF-36v2 health survey is a 36-question survey that measures an individual's overall health status-both physical

\footnotetext{
${ }^{32}$ The survey was provided to the researcher by an official from QualityMetric Health Outcomes Solutions. More information on the survey can be accessed at: http://www.sf-36.org/tools/sf36.shtml.
} 
and mental-and can be completed in approximately 10 minutes. Its questions are relatively non-invasive, and it has been found to be "a valid measure of the health status of a wide range of patients" (Garratt, Ruta, Abdalla, Buckingham, \& Russell, 1993, p. 1440). The survey is widely used in health research. Thus, in future, researchers using a similar methodology with this subpopulation (but larger sample size) will have the option of comparing scores from their study to that of similar subpopulations-e.g. low income Canadians, general population of Canada, etc. (Garratt et al., 1993).

\subsubsection{Data Organization and Analysis}

Notwithstanding the fact that this was an exploratory study with a very small sample size, one goal was to summarize and synthesize information on expenditures and income sources across participants. The researcher sought to establish as accurately as possible how much money each participant spent per month on housing, food, toiletries, transportation, entertainment and all other goods. This included irregular spending on 'big ticket' items (such as furniture) and 'one offs,' such as the purchase of identification (i.e., a driver's license). In light of the implications for health outcomes, there were questions on how much money was spent each month on fruit, vegetables, milk products, tobacco products, alcohol and illicit drugs. The researcher also asked hypothetical questions about spending, such as "If you had an additional \$100 every month, what would you spend it on?"

The researcher sought to establish monthly revenue by asking each participant how much he received each month in SA benefits (including "extras" such as the Special Diet Allowance), employment income (both declared and undeclared work), panhandling, irregular sources of income such as the Goods and Services tax credit (and the 
Harmonized Sales Tax credit), money from legal settlements, money from a girlfriend or boyfriend, money from family, money from the sale of illicit drugs and money from sex work.

During each interview, results were recorded by hand; after the interview was over, results were typed into a Microsoft Word document. Averages were then computed with a calculator. A detailed accounting of expenses by category—both at the individual level and as an aggregation of all interview subjects-is presented in Appendices E and F. It is a quantified summary that complements the summary of narratives that will be provided in the Results section below. This data is presented both in dollar terms and as a percentage of monthly expenditures. Caution should be used when interpreting the data, as the sample size is small. Although expenses as a percentage of each interview subject's monthly budget are presented in Appendix 2.5, placing emphasis on aggregations in percentage terms for such a small sample size can be misleading and, therefore, is generally frowned upon in social welfare research. As Weinbach and Grinnell (2010, p. 32) argue: "Percentages are generally meaningless...if not misleading, in reporting data from small samples...Percentages convey the impression that findings were based on a larger numbers [sic] of cases (100 or more)." Thus, while the reader may wish to peruse Appendix 2.5 for further detail, a summary of aggregated changes in expenditures as a percentage of budgets will not be presented in the body of the present essay. 


\subsubsection{Ethics}

This kind of research requires a high level of ethical sensitivity for two reasons. First, there is a great deal of stigma associated with being on SA. Second, there are potential repercussions if a recipient of SA is found by their caseworker to be in breach of any of the criteria for receiving benefits.

Ethics applications were submitted to the REB at Carleton University, where the researcher is a full-time student, and the REB at St. Michael's Hospital, where one of his Committee members is Director of the Centre for Research on Inner City Health. ${ }^{33}$ No major problems were encountered with either REB. Carleton's REB approved the application with one reservation: REB officials expressed a greater comfort level with the researcher interviewing men rather than women (especially if the interview was going to take place in the interview subject's home). As discussed above, this had a role in shaping the study's methodology. The REB at St. Michael's Hospital, by contrast, asked the researcher to outline a plan of "what measures will be taken for those with extreme scores on emotional health questions (e.g. that may be indicative of depression or harm)." The researcher explained to both REBs that, having been a mental health outreach worker for seven years, he knows how to appropriately refer participants to medical care if they are distressed or express suicidal ideation during the course of the interview. During the dissemination phase of the research (post-defence), the researcher will contact all participants inviting them to any public presentations of the study results.

\footnotetext{
${ }^{33}$ Initially, it was hoped that funding for the present study would be secured from a major granting council, and that Dr. O'Campo would be Principal Investigator on the grant application. This required REB approval from St. Michael's Hospital, where Dr. O'Campo is employed.
} 


\subsection{Results}

The essay will now provide an overview of results. It will begin by providing an overview of key themes that emerged from the 'stories' told throughout the interviewing process. While recognizing that the sample size is small, some themes do emerge. The essay will then provide brief narratives for each respective interview subject, recognizing that the interviews were not exclusively about dollars and cents. Indeed, some questions were broad, many were open-ended, and some were hypothetical. An overview of reported monthly expenses, reported monthly revenue and reported health status will then be provided. The section will conclude by providing a summary of self-reported challenges to food purchases.

Tables with detailed, quantified summaries of each interview subject's respective expenses and revenue are provided in Appendices 2.5-2.8. These tables clearly identify how many interviews were completed by each respective interview subject. Appendix 2.4 contains a summary of monthly expenses by category (in dollars). Appendix 2.5 contains a summary of monthly expenses by category (expressed as a percentage of total monthly expenses). Appendix 2.6 contains a summary of monthly revenue by category (in dollars). Appendix 2.7 contains a summary of monthly revenue by category (expressed as a percentage of total monthly revenue). 


\subsubsection{Emerging Themes}

Five emerging themes are apparent across multiple interview subjects. Though some are intuitive, several were rather unexpected and are worth pursuing in future research. First, several interview subjects report accessing improved health and dental coverage once on ODSP. This reflects ODSP's superior health and dental coverage, but it is a point that receives virtually no research or policy attention. Indeed, although some information about health and dental coverage can be gleaned from Ontario Works Policy Directives and ODSP Income Support Directives, it is unclear from this information exactly what level of coverage is available for either OW or ODSP recipients. ${ }^{34}$

Second, once on ODSP, interview subjects reported making fewer trips to food banks and meal programs. Third, once on ODSP, several interview subjects reported purchasing less in the way of illicit drugs and alcohol; and this came as a surprise to the researcher. A fourth theme was individuals having to 'pay to work.' Indeed, whether it was before or after transitioning to ODSP, several interview subjects reported paying union dues; another reported buying art supplies for work. Yet another incurred substantial expenses for taxis and food in order to maintain his job. A fifth theme is that more than one interview subject reported being more liberal with his expenses, once on ODSP. While recognizing the present study's small sample size, researchers conducting future research on budgets of very low-income singles should consider incorporating

\footnotetext{
${ }^{34}$ Information on Extended Health Benefits available through OW is available here: http://www.mcss.gov.on.ca/documents/en/mcss/social/directives/ow/0703.pdf, while information about ODSP dental benefits is available here: http://www.mcss.gov.on.ca/documents/en/mcss/social/directives/odsp/income_Support/9_7.pdf
} 
these emerging themes into their interview guides. Each theme will be further discussed below, as it relates to individual interview subjects.

\subsubsection{Narratives From Each Key Informant}

Informant 1. During the first three interviews, Informant 1 reported living in a government-subsidized boarding home with 16 other residents. Though the boardinghome operator was required to provide residents with three meals a day, the quality of food was questionable. According to the informant, there was "lots of white rice with kidney beans." To supplement the food he was served at the boarding home, he visited food banks, especially to acquire Ensure and Carnation Instant Breakfast. His foodshopping strategies included taking advantage of sales and doing most of his shopping at No Frills.

While on OW, he reported paying \$60 a month in supplemental medical insurance to cover heart medication, Epipens, diabetic supplies and eye wear. But once on ODSP, his improved health coverage made it unnecessary to incur this additional out-of-pocket expense on a monthly basis. Also, once on ODSP, he reported that he no longer needed to go to food banks. Finally, while on OW, he had reported spending $\$ 140$ a month on illicit drugs and alcohol; but once on ODSP, he reported spending nothing on illicit drugs and alcohol. In his words, now that he was receiving higher monthly benefits, it was "time for a change."

Informant 2. Informant 2 reported living in a subsidized Toronto Community Housing Corporation unit for one year at the time of Interview \#1. The subsidized aspect of this housing arrangement appears to have had important implications for his monthly budgeting. In his words: "I never starve now that I'm in Toronto Housing." That said, he 
described his neighbourhood as "terrible." He has "good neighbours and bad neighbours; the good ones, you don't see much!" He also reported that there are:

...two crack dealers on my floor and people up all night and yelling outside my door. People let people in [to the building] to deal out of their housing units...I need to spend my money each month before getting back to my housing unit. If I have money by the time I get back to my housing unit, I spend on things I don't want to.

One of his shopping strategies is to go to the 'dollar store' every month. Another is to buy "staples" at the beginning of each month right after cashing his OW cheque, and then relying on food banks: "I use four food banks. I'm at a food bank at least once a week. I also go to Good Shepherd once a day for a meal."

Informant 3. Informant 3 reported going to a lot of meal programs, with the precise time that the meal was served being important for health-related reasons: "Morning is when I have the most energy to walk to a meal program." After transitioning to ODSP, he reported having to go to food banks less frequently, but eating more fast food. Also after the transition, he reported buying "higher quality" foods — whereas he used to buy $\$ 3$ steaks, he now bought $\$ 7$ steaks. In his words: "I spend less time hunting for bargains now... I've loosened the purse strings a bit." He reported, for example, buying COLDFX once on ODSP, something he would not have considered buying while on OW.

Informant 4. Almost immediately after Informant 4 made the transition to ODSP, he took advantage of his new-and-improved health and dental coverage. He bought $\$ 650$ glasses — $\$ 450$ of which was covered by his ODSP vision coverage, and \$200 of which he paid with the basic needs portion of his ODSP cheque. He also got approved for a $\$ 1,500$ hearing aid, for which he had not been eligible under OW. Finally, he got his teeth cleaned and cavities filled: 
They took the silver out and put white fillings in. I also got two chips on my teeth replaced. I have a straight smile now. It makes a big difference when I interact with people.

All of the above happened within two months of Informant 4 receiving his first ODSP cheque.

Once on ODSP, Informant 4 also reported no longer using food banks, and rarely using meal programs. As a result, his monthly food purchases increased from $\$ 60$ to $\$ 250$. He reported purchasing a "big cable package" as well. His monthly spending on cigarettes increased from $\$ 40$ to $\$ 150$. His monthly spending on alcohol: \$25 to \$200. And illicit drugs: from \$175 to \$250.

Informant 5. Informant 5 was not reachable after his third interview; thus, results obtained reflect only his budgeting while on OW. He reported working approximately 25 days per month, and earning \$50 in cash payments for each day’s work (over and above his OW benefits). However, he also reported incurring substantial cash outlays while at work, including: \$24 per day for food; \$370 per month in taxi fares (both to acquire his lunch and to purchase work-related supplies at hardware stores); and $\$ 5$ per day for cigarettes.

Informant 6. Informant 6 was not reachable after his second interview; thus, all information obtained on his budgeting relates to his situation while on OW. He reported living in a room in the back of a house via a barter arrangement: he was living there rentfree in exchange for doing art work for the owner. The room had no bathroom or kitchen. He therefore was not buying groceries at the time. He did report spending $\$ 50$ per month to see a chiropractor, and $\$ 120$ per month for art supplies. 
Informant 7. Informant 7 lives in a subsidized bachelor apartment unit. He became unreachable after the third interview, meaning that all of his interviews were conducted while he received OW. While on OW, he earned approximately $\$ 350$ per month in income from casual labour at a job that pays $\$ 13-\$ 14 / \mathrm{hr}$. (with no benefits). He also reported paying approximately $\$ 40$ per month in union dues. Finally, he noted that, though he files an income tax return each year, any rebate is garnished in light of childsupport payment arrears.

Informant 8. Informant 8 reported working two jobs at the beginning of the interview process. Specifically, he reported working a $\$ 25 / \mathrm{hr}$. unionized job (without benefits) that netted him approximately $\$ 600$ per month in income, but on a casual basis. He also reported working a $\$ 15 / \mathrm{hr}$. "under the table" job for a carpenter friend. He also reported paying $\$ 50$ per month in union dues and $\$ 70$ per month for medical benefits. By the fifth interview, however, he reported having been let go at his unionized job, and making up the shortfall in part by "returning empties"- -specifically by collecting bottles from residences on "blue days" with a shopping cart. For this, he earned $\$ 150$ per month.

When asked how his purchases changed after making the transition to ODSP, he noted: "I was a little more liberal grabbing a coffee or buying beer at the LCBO." After the transition, he also reported going to food banks less and not having to "sneak on" public transit anymore. Also after the transition to ODSP, he reported spending less money on illicit drugs. When probed about the matter, he noted: "I am making a lifestyle change now."

Informant 9. Informant 9 became unreachable after the second interview. He had reported sharing a house with five other men. He expressed frustration at not yet being 
approved for ODSP; he had been trying to gain approval for several years. He noted: "I have cancer. I'm blind in one eye. Yet, they're still telling me I'm not handicapped." $\mathrm{He}$ had a cat and obtained free veterinary services from a vet he knows from church. He works as a busker. When asked what he would do if given $\$ 100$, he said he would buy more balloons. When asked what he would do if given $\$ 400$, he said he would buy municipal busker permits.

Informant 10. Informant 10 did not successfully make the transition to ODSP, reportedly because his medical assessment was "not favourable." Thus, all six interviews took place while he was receiving OW. He reported having incurred a substantial amount of fines due to speeding-related infractions while driving a car he previously owned. Over the previous two-year period, he had paid $\$ 1000$, both for the infractions and to reacquire a driver's licence. He reported going to food banks eight times per month. He also reported receiving just over $\$ 300$ per month from family, and over $\$ 60$ per month from his ex-wife. In winter months, he reported earning \$200 per month snow shovelling. He reported recently receiving more than $\$ 4,000$ from three years' worth of tax returns, but spending "all of it at the casino." Finally, he reported earning $\$ 60$ per month in exchange for allowing another individual to sleep at his housing unit.

\subsubsection{Summary of Expenses by Category}

In considering the four interview subjects who successfully made the transition from OW to ODSP, it appears as though some emerging themes may be worth pursuing in future research. For example, in looking at monthly dollars spent, all four interview subjects reported spending significantly more per month on food after the transition. Further, most interview subjects who completed all six interviews reported spending 
substantially more on fruits and vegetables after the transition to ODSP. Three of them more than doubled their expenditure (in dollars) on fruit and vegetables; only one of the four reported spending less on fruit and vegetables after the transition. All four reported spending substantially more money on household products after the transition. And three of the four reported spending significantly more money on gifts after transitioning to ODSP.

\subsubsection{Summary of Revenue by Category}

A key reason for looking at revenue in this study is to be able to assist with the reconciliation of each interview subject's estimated monthly budget. In other words, asking about revenue is key to understanding expenditure. Nevertheless, and keeping in mind the small sample size, there do appear to be some emerging hypotheses worth pursuing in future research. For example, the researcher had not predicted that income from SA would very often represent just half of an interview subject's total monthly income. This is noteworthy for two reasons. First, it suggests that singles on SA receive a substantial amount of income from outside sources that they do not declare to SA administrators (i.e. singles on SA may receive a considerable amount of undeclared income). Second, given that interview subjects offered this potentially-incriminating information to the researcher, it suggests that interview subjects were being very open with the researcher, and that the researcher had gained their trust. It is hard to imagine why a low-income individual would offer such sensitive information to a researcher if it were not factual.

Another somewhat unexpected outcome was that health benefits (i.e. dental benefits, diabetic supplies, vision coverage, etc.) are considerably more generous for 
ODSP recipients than for OW recipients. For example, in addition to Informant 4's story (noted in the narratives section above), one interview subject (Informant 1) reported receiving more than twice as much money for diabetic supplies, on a monthly basis, once on ODSP. While some may not consider this to be a new discovery per se, the researcher himself was only notionally aware of this when interviews began, and had not expected there to be such a significant difference in supplementary health coverage for certain recipients. General guidelines pertaining to the Emergency Dental Program for Adults in receipt of Ontario Works can be found at the City of Toronto's web site. The guidelines in question contain very few details. Dental benefits for ODSP recipients are explained in the Ministry of Community and Social Services (MCSS)' Schedule of Dental Services and Fees. OW coverage for diabetic supplies is outlined in the OW Policy Directives. ODSP coverage for diabetic supplies is outlined in ODSP's Income Support Directives. OW coverage for vision care is outlined, rather vaguely, at the MCSS web site. ODSP coverage for vision care is outlined in ODSP's Income Support Directives.

Yet another emerging theme with respect to monthly revenue relates to monetary gifts received. Most interview subjects reported receiving monetary gifts on a regular basis while on OW. Once on ODSP, no interview subject reported receiving gifts. Though the nature of the gifts was not thoroughly probed, it would appear that two factors may be at play here: 1) interview subjects ask friends and family for money less frequently once they have a higher monthly income; and 2) friends and family may be inclined to give money less when they know the interview subject is in receipt of considerably higher monthly income from government sources. Again though, with this small sample size, one must be careful not to generalize from these findings. 
It is also worth noting that three of the four interview subjects who made the transition to ODSP saw a significant decrease in reported monthly income from casual labour. Insofar as this may be indicative of an emerging theme, this will be rather intuitive for many readers. The higher an individual's monthly income from government sources, the less inclined that individual might be to work odd jobs (especially nonstandard jobs that likely have less-than-optimal working conditions). A detailed breakdown of before-and-after monthly revenue can be found in Appendix 2.6 and 2.7, expressed in dollars and percentage of monthly revenue respectively.

\subsubsection{Summary of Health Status}

Results of the SF-36v2 health surveys (known as "respondent reports") are presented in Appendix 2.8. In light of the small sample size, the present section will not present an aggregation of changes. That said, it is worth noting that the only discernible theme from respondent reports is that they suggest no emerging patterns or themes. If anything, the scores suggest that future use of the SF-36v2 health survey with a comparable methodological approach may not result in useful results unless they are used with a very large sample size. Informant 1 , for example, saw a slight deterioration in both physical and mental health after successfully making the transition to ODSP. Informant 3 saw a slight deterioration in physical health and slight improvement in mental health after marking the transition. Scores for Informant 4 and 8, by contrast, went in the opposite directions as those of Informant 3 after transition (and on a slightly greater scale in each case).

Informants 2 and 10 were each followed for six interviews but did not successfully make the transition. The former saw a slight decrease in his physical health 
score, and a very significant improvement in mental health score. By contrast, the latter saw changes in the opposite directions, experiencing a slight improvement in physical health score, and a significant deterioration in mental health score. 


\subsubsection{Self-Reported Challenges With Respect to Food Purchases}

During both the second and fourth interviews, respondents were asked the following question: "What would you say is your biggest problem when it comes to food purchases?" The answers to this question are summarized in the Table 2.2.

Table 2.2

Biggest Problems When it Comes to Food Purchases

\begin{tabular}{ll}
\hline Interview subject \#1 & $2^{\text {nd }}$ interview: Not enough money \\
& $4^{\text {th }}$ interview: Difficult to carry groceries \\
\hline Interview subject \#2 & $2^{\text {nd }}$ interview: Not enough money \\
& $4^{\text {th }}$ interview: No problem \\
\hline Interview subject \#3 & $2^{\text {nd }}$ interview: Did not answer \\
& $3^{\text {rd }}$ interview: Did not answer \\
\hline Interview subject \#4 & $2^{\text {nd }}$ interview: Lack of cooking skills \\
& $4^{\text {th }}$ interview: Did not answer \\
\hline Interview subject \#5 & $2^{\text {nd }}$ interview: Transporting it on public transit \\
& $4^{\text {th }}$ interview: No $4^{\text {th }}$ interview \\
Interview subject \#6 & $2^{\text {nd }}$ interview: Not having a kitchen \\
& $4^{\text {th }}$ interview: No $4^{\text {th }}$ interview \\
\hline Interview subject \#7 & $2^{\text {nd }}$ interview: Does not eat pork and is lactose \\
& intolerant \\
& $4^{\text {th }}$ interview: No $4^{\text {th } \text { interview }}$ \\
Interview subject \#8 & $2^{\text {nd }}$ interview: Not enough money \\
& $4^{\text {th }}$ interview: Did not answer \\
\hline Interview subject \#9 & $2^{\text {nd }}$ interview: Not enough money \\
& $4^{\text {th }}$ interview: Did not answer \\
\hline Interview subject \#10 & $2^{\text {nd }}$ interview: Generally eats unhealthy meals \\
& $4^{\text {th }}$ interview: Did not answer \\
\hline
\end{tabular}




\subsubsection{Post-Survey Reflections on Methodology}

Notwithstanding this study's small sample size, noteworthy results from interviews include: participants receiving improved health and dental benefits after transitioning to ODSP; several participants spending substantially more on fruits and vegetables after transitioning to ODSP; multiple participants reporting less spending on alcohol and illicit drugs once on ODSP; and a number of participants making fewer trips to food banks and meal programs.

Keeping in mind that a main goal of the study was to establish a methodology for future research, a reflection on methodology in the present section is appropriate. With the interviews complete, this section will therefore provide a brief, retrospective overview of how the planned methods fared in this study. It will discuss early contact with Project HOPE officials, initial telephone conversations with interview subjects and feedback received from interview subjects about process.

\subsubsection{First Meeting with Program Officials}

In October 2009, the researcher met with Toronto Employment and Social Services (TESS) staff at the Director and manager level. TESS staff were interested in the research project and open to supporting the researcher. Two factors contributed to this outcome. First, the researcher had been introduced to them by a colleague (a physician associated with HOPE) who worked with their clients and was trusted by them; she had spoken highly of the researcher, as she had known him from his time as a community worker. Second, and along similar lines, they expressed that the researcher's decade of experience as a front-line community worker in Toronto was reassuring. 


\subsubsection{Phone Calls}

Clients began calling the researcher in April 2010. Callers spoke with an eager tone. First "screening" calls typically lasted 15-20 minutes. Many participants expressed a preference for speaking by telephone after 6PM on weekdays, or any time on weekends-their phone plans generally allowed free calls during those periods.

The telephone script appears to have made privacy provisions very clear to clients. In fact, both during the researcher's reading of the telephone script and during the first interview, interview subjects would frequently say something along the lines of: “OK, OK, I get the privacy thing! You're not going to tell on me. I'm not worried."

Even when callers missed the researcher when they called the first time, several called back multiple times-even weeks later. Also, several callers left a number that they could be reached at, and in all cases the researcher was able to reach them successfully. Some called again shortly before the scheduled interview to confirm, even though they had not been asked to do so. In terms of a location for the interview, each interview subject was asked if there was a coffee shop located in an area that was convenient for them. In all cases, they knew of one and suggested it.

In consultation with Dr. O'Campo, the researcher allowed one exception to the eligibility criteria for the study: he allowed a single male on OW who had recently applied for ODSP (but was not a HOPE participant) to participate. This individual had been shown a flyer by a friend and phoned the researcher, asking if he could participate. Dr. O'Campo and the researcher both agreed that it would be worthwhile to see if there are any discernible differences between how a non-HOPE participant was experiencing the transition from OW, as compared with HOPE participants. This is also in keeping 
with the following perspective articulated by Dunn: "The non-random assignment of subjects and other messy aspects of such research, rather than things to be disdained, are useful, as they provide learning opportunities" (Dunn, 2012, p. 40).

\subsubsection{Feedback on Process}

During the sixth and final interview, informants were asked how they found the interview process-that is, how they found the location of interviews, the timing of the interviews and the accessibility of the researcher (in the event that they needed to reach him in between interviews). They were also asked how they felt about discussing expenses, discussing income and completing the SF-36v2 health survey. Feedback on all of the above points was generally positive. In fact, the one consistent theme is that interview subjects felt comfortable with the interview process as a whole. They did not find it intrusive, though some did identify points in the process where they felt mildly uncomfortable. What follows are some specific points made by the six interview subjects who completed all six interviews.

Informant 1 characterized the process as "an easy study," and "not as intrusive" for example as the Mental Health Commission of Canada's At Home/Chez Soi study, in which he has also participated; the latter includes three-hour interviews, as opposed to the one-hour interviews required for the present study. In his words: "Three hours is a lot of time! My mind starts to wander after an hour." He also expressed interest in learning about the results of the present study: "Pretty much every study I've been involved with, I've wanted to know the end result. This one seems interesting. I don't like the idea of studies gathering dust after they're done." 
Informant 2 expressed a comfort level with respect to confidentiality throughout the process: "You kept restating the confidentiality provisions...," which put him at ease. He also stated that he appreciated not being asked how he spent the honorarium he received for each interview: “I liked that you didn’t ask me how I spent the \$25 you gave me.” He expressed that he did not find the process as intrusive as he expected: "I thought there' $\mathrm{d}$ be more digging. I almost thought it was too soft." And on more than one occasion, he expressed that he enjoyed the interview process: "I don't have a chance to talk like this much. I enjoy it."

Informant 3 stated that it made him quite uncomfortable when he was asked if he pays for sex work: "I found it a bit offensive when you asked if I pay for hookers. That's the only one that made me uncomfortable. That's the one question I found too personal. I understand why you asked it though; it's my own fault that I felt strange answering it. It made me feel bad about what I'd done. You were right to ask the question though."

Informant 4 stated that, looking back, the coffee shop where the interviews took place was not a good location: “Other people could hear questions as you asked... [and] handing me cash in a visible way made me feel uncomfortable." He stated that a better location would have been at a library or park (in good weather). He also pointed out that, had the interviews taken place outside, he could have smoked as he answered questions. Finally, he expressed discomfort over the SF-36v2 health survey's questions about work: “Questions about work made me uncomfortable, as I don’t work."

When asked about questions about income, Informant 8 expressed that he was being truthful, but that there are limitations as to how truthful he would be willing to be, 
at least hypothetically: "If I'd committed a robbery, I'd have told you. But if I'd hurt someone in the process, I wouldn't have."

Finally, Informant 10 stated that the questions about revenue in general made him "uncomfortable." In his words: "It was a reminder of how little I get on social assistance." 


\subsection{Discussion}

The methods used to undertake this research were not straightforward. First, it is challenging for any researcher to access individuals on welfare. Second, it is even more difficult to access individuals on welfare who expect to start receiving a substantial increase in benefits in the relatively short term. Third, the idea of asking SA recipients detailed information about both their monthly expenses and sources of income other than SA benefits requires asking them to divulge potentially incriminating information. With those three points in mind, this section will begin by discussing the study's strengths, which include the partnership forged with TESS, the ability of the researcher to replicate Edin and Lein's methodology, the frankness with which interview subjects spoke, and the apparent success of budget reconciliation. The study's limitations will then be discussed-this will include a consideration of the fact that results were based on selfreporting and that the sample size is small. Finally, this section will discuss implications of this research for future research.

\subsubsection{Study's Strengths}

One of the study's strengths was the positive working relationship nurtured with Project HOPE officials. This merits some reflection. Officials who administer SA programs across Canada work in an unpopular field that rarely attracts positive media attention. That several Project HOPE officials met on multiple occasions with the researcher, in and of itself, was a strength. But the fact that they cooperated with the researcher on a study that was going to ask questions that could potentially embarrass their program was an important research breakthrough. Further, they insisted on only assisting with the initial connection with clients, and not being involved in the research 
beyond that point so as to ensure an arm's length, independent arrangement. This showed trust in both the researcher and in Dr. O'Campo. It also illustrated an important level of confidence held by Project HOPE officials in the integrity of their own program.

A second strength, which proved indispensable, was the availability of seed funding, thanks to Dr. O'Campo. This allowed the research to begin very quickly and proceed smoothly. It allowed the researcher to travel frequently to and from Toronto, allowed each interview subject to be paid promptly; and it allowed for the purchase of SF-36v2 software. No comparable seed money was available from the researcher's university.

Third, take-up and eagerness on the part of interview subjects was strong. Even though many interview subjects did not own their own telephones, participants had no apparent difficulty reaching the researcher on his cell phone - a point which was confirmed by interview subjects during Interview \#6 when they were asked about process. It was also typical for the interview subjects to arrive early; 'no shows' were exceptional. And as the first interviews wrapped up, the researcher generally got the impression that participants would have happily continued to talk longer. Interview subjects were frank in stating that the $\$ 25$ honorarium (plus $\$ 5$ worth of transit tokens) was a major motivating factor in their participation; but they also expressed other reasons for participation. First, several appeared eager to 'set the record straight' with respect to what low-income individuals in fact spend money on. Second, several interview subjects indicated that they did not have somebody in whom they could confide and trust on personal matters. There were no 'incidents' stemming from conflict between interview subject and researcher at any stage of the process. 
Another strength was the success of the reconciliation process, which took place during Interview \#3 and Interview \#5 respectively. The researcher was generally able to make each side of the ledger, so to speak, come to within $\$ 50$ of the other, as suggested by Edin and Lein (1997). There was one interview subject whose initial answers were $\$ 1500$ apart. But, even in that case, after roughly 30 minutes of probing, the discrepancy was brought down to roughly $\$ 100$. Many interview subjects were able to get to within $\$ 50$ on the very first try. And when there was further probing, interview subjects were generally patient and willing to reduce the discrepancy.

\subsubsection{Study's Limitations}

Over the course of the many interviews, several hours were spent with most interview subjects, allowing the researcher to gather in-depth information. There was, however, one limitation of this study and that is its sample size. In future, a larger sample size would allow for some generalization, and therefore some policy recommendations. For example, if a larger sample saw no net change in the purchase of fruits or vegetables after seeing a 78 percent increase in monthly income, one might conclude that more targeted food security inventions would be more effective at improving nutritional intake than would an increase in cash benefits. But no such conclusions can be drawn from the

present study, even though it helps lay the methodological groundwork for a larger study.

A second limitation of the study is that it is based on self-reporting. Indeed, it is impossible to know for certain if interview subjects were being truthful in their answers. It is conceivable, for instance, that some interview subjects underreported monthly income from non-SA sources. It is likewise conceivable that some interview subjects underreported their monthly purchases of illicit drugs, alcohol and cigarettes, so as to not 
be risk being judged by the researcher. Nonetheless, considering the potentiallyincriminating information that was reported, as well as some candid answers on hypothetical questions, it does appear that interview subjects developed a level of comfort with the researcher. Also, short of 24-hour-a-day video surveillance, it is hard to conceive of a methodological approach that would assure complete accuracy. Though receipts could conceivably be asked for in a similar study, it would be extremely easy for an interview subject to obtain receipts from purchases made by other individuals; one need only spend a short amount of time near the check-out section of a large grocery store in order to quickly retrieve discarded grocery story receipts, for example.

\subsubsection{Implications for Future Research}

Project HOPE has been evolving, meaning that there is opportunity for future research using this methodology. The program now operates out of seven of Toronto's social assistance offices, having moved beyond just downtown offices into a number of suburban sites. HOPE officials also do intakes at hospitals. Further steps including intakes in detention centres are also being investigated. A similar program, called as the ODSP Application Support Worker Program, has existed in Ottawa since 2005. The Ottawa program is a partnership between Centre 454 and the Ottawa branch of the Canadian Mental Health Association. In May 2010, it expanded to include three “application support workers.” In 2011, the program assessed almost 500 new clients, approximately 70 percent of whom were singles (Anglican Social Services - Centre 454, 2012). In short, HOPE's model is becoming increasingly popular in Ontario, and this may lead to further research opportunities. 


\subsubsection{Methodological implications for similar research.}

One methodological implication of the present study relates to retention of interview subjects. Based on this experience, other researchers looking to replicate this methodology (with the same subpopulation) should expect to retain approximately half of key informants all the way through to a sixth interview. In other words, if the goal is to ultimately have results for 300 interview subjects based on six interviews per interview subject, it would be advisable to conduct initial interviews with 600 interview subjects. It should also be borne in mind that many of the interview subjects who are retained for six interviews will not have successfully made the transition to ODSP — though, as previously noted, this was anticipated in the present study as well. Indeed, participants in Project HOPE are in the process of applying for ODSP. While Project HOPE has a strong success rate in moving clients on to ODSP, it does not have a 100 percent success rate. $^{35}$

A second methodological implication for future research appears to be that a similar level of remuneration (i.e. $\$ 25+$ two one-way transit tokens) should suffice. ${ }^{36}$ At no point did the level of remuneration appear to deter participation by interview subjects. While it is possible that a slightly lower level of remuneration would suffice, given the challenges experienced with respect to retention, it might be imprudent to experiment with a 'less generous' approach to remuneration.

\footnotetext{
${ }^{35}$ Factors that determine whether or not they are approved include: a) whether they continue to see their caseworker and follow up on appointments; b) the content (i.e. the 'strength') of their ODSP application; and c) the outcome of the eventual decision made by officials (be it within the Disability Adjudication Unit or within the appeal body in the event that the initial decision is challenged by the client).

${ }^{36}$ It should also be noted that, at the beginning of each interview, the researcher typically bought the interview subject a cup of coffee and a food item of their choice.
} 
A third methodological implication is that coffee shops and fast food restaurants appear to serve as good locations for interviews. At no point during the interviews did staff or other customers ask us to leave; in fact, at no point did they even appear to notice that an interview was in progress. Likewise, at no point during interviews did a client express difficulty in travelling to the location, or in speaking freely in these environments. However — and as previously mentioned — one interview subject did express some privacy concerns after the fact; he also suggested that interview subjects in future be offered the opportunity to smoke during the interviews (i.e. at a coffee shop with a patio).

A fourth methodological implication for future research pertains to the use of the SF-36v2 health survey. As discussed above, no emerging themes were apparent in terms of health status after interview subjects transitioned to ODSP. Obviously, this could mean that a slight increase in SA benefit levels may result in no improvement in health status for this demographic. But another possibility is that there is a latency period involved such that a low-income individual must be receiving the higher benefit levels for a longer period (i.e. two to three years) before changes in health status can be measured. Yet another possibility is that the SF-36v2 health survey is very sensitive to recent events (i.e. trauma experienced in the previous few days, sleep deprivation experienced the night before, etc.), and this masks overall health status for this subpopulation. Use of the SF-36v2 with a larger sample (and possibly over a longer period) could help shed light on this apparent conundrum. 


\subsubsection{Hypotheses for similar research.}

In the Results section above, five emerging themes from this study are discussed. Based on the five emerging themes, five hypotheses to be examined in similar research can now be identified. They are as follow: 1) after singles transition from OW to ODSP, most will claim the new health and dental benefits for which they become eligible; 2) after singles transition from OW to ODSP, they will rely less on food banks and meal programs; 3) many (but not all) singles who move from OW to ODSP will spend less money on alcohol and illicit drugs after the transition; 4) many singles on OW and ODSP spend significant amounts of their income on employment-related expenses (i.e. they pay to work); and 5) many singles who transition from OW to ODSP will be 'more liberal' in their spending after the transition. 


\subsubsection{Conclusion}

The budgeting of SA recipients has received almost no academic attention. Though spending on SA constitutes significant shares of provincial budgets in Canada, researchers know very little about what SA recipients do with the money they receive. Without this information, it is challenging to have informed debates about appropriate benefit levels. This essay takes an important step towards helping fill this void and, though the sample is small, found that, after transitioning to ODSP: many participants receive improved health and dental benefits; some report spending substantially more on fruits and vegetables; several report less spending on alcohol and illicit drugs; and some make fewer trips to food banks and meal programs. The questions asked in this essay were asked with the invaluable assistance of SA officials in Canada's largest city. In effect, a door was opened for the researcher, providing him an opportunity to recruit SA recipients for this research. The recipients in turn were cooperative, apparently being very open about what they spend their money on each month. The exercise reveals that: budgeting research with SA recipients can be done; cooperation can be received from both SA officials and the recipients themselves; and an open dialogue is indeed possible.

This essay also provides a template (adapted from Edin and Lein) of what kind of methodological approach would work when conducting similar research, especially with single adults receiving last-resort SA. Further, the essay provides some hypotheses that can be tested in future research (especially with singles on last resort SA); at the very least, such hypotheses should be borne in mind by others wanting to study budgets of low-income individuals. 
In summary, the budgeting of SA recipients clearly merits further academic study, and this essay provides a methodological framework that future researchers can and should use to undertake such study. 


\subsubsection{Reference List}

Anglican Social Services - Centre 454 (2012). ODSP application support worker program: Outcomes report 2011. Unpublished report.

Britten, N. (1995). Qualitative interviews in medical research. British Medical Journal, 311 (6999): 251-253. Retrieved from: http://www.bmj.com/

Carpiano, R. M., Link, B. G., \& Phelan, J. C. (2010). Chapter 8: Social inequality and health: Future directions for the fundamental cause explanation. In A. Lareau \& D. Conley (Eds.), Social class: How does it work? (pp. 232-263). New York, NY: Russell Sage Foundation.

Drummond, D. \& Manning, G. (2005). From welfare to work in Ontario: Still the road less travelled - TD Economics Special Report. Retrieved from TD Bank Financial Group website: http://www.td.com/document/PDF/economics/special/td-economicsspecial-welfare05.pdf

Dunn, J. R. (2012). "Explanation," philosophy and theory in health inequalities research: Towards a critical realist approach. In P. O'Campo \& J. R. Dunn (Eds.), Rethinking social epidemiology: Towards a science of change (pp. 23-42). doi:10.1007/978-94007-2138-8 2

Edin, K. \& Lein, L. (1997). Making ends meet: How single mothers survive welfare and low-wage work. New York: Russell Sage.

Garratt, A.M., D. A. Ruta, M. I. Abdalla, J. K. Buckingham \& I. T. Russell. (1993). The SF36 health survey questionnaire: an outcome measure suitable for routine use within the NHS? British Medical Journal, 306(6890): 1440-44. Retrieved from: http://www.bmj.com/

Hainsworth, G. (2009). Homeless to ODSP Project Engagement (HOPE). Unpublished fact sheet.

Kirkpatrick, S., \& V. Tarasuk. (2003). The relationship between low income and household food expenditure patterns in Canada. Public Health Nutrition, 6(6): 58997. Retrieved from http://journals.cambridge.org/action/displayJournal?jid=phn

Kirkpatrick, S. (2008). Food insecurity is associated with nutrient inadequacies among Canadian adults and adolescents. Journal of Nutrition, 138(3), 604-612. Retrieved from http://jn.nutrition.org/

Kvale, S. (1996). Interviews: An introduction to qualitative research interviewing. Thousand Oaks, Calif.: Sage Publications. 
Lankin, F., \& Sheikh, M. A. (2011). A discussion paper: Issues and ideas. Retrieved from the Commission for the Review of Social Assistance website: http://www.socialassistancereview.ca/

Lugo-Gil, J. \& Yoshikawa, H. (2006). Assessing Expenditures on Children in LowIncome, Ethnically Diverse and Immigrant Families. Retrieved from http://www.npc.umich.edu/publications/u/working_paper06-36.pdf

Lundberg, O., \& Manderbacka, K. (1996). Assessing reliability of a measure of self-rated health. Scandinavian Journal of Social Medicine, 24(3): 218-24. doi: $10.1177 / 140349489602400314$

Marmot, M. (2002). The influence of income on health: Views of an epidemiologist. Health Affairs, 21(2): 31-46. Retrieved from http://www.healthaffairs.org/

McKague, M., \& Verhoef, M. (2003). Understandings of health and its determinants among clients and providers at an urban community health centre. Qualitative Health Research, 13(5): 703-717. Retrieved from http://qhr.sagepub.com/

Mendenhall, R., Edin, K., Crowley, S., Sykes, J., Tach, L., Kriz, K., \& Kling, J. R. (2012). The Role of Earned Income Tax Credit in the Budgets of Low-Income Households. Social Service Review, 86(3), 367-400.

Mistry, R. S., Lowe, E. D., Benner, A. D., \& Chien, N. (2008). Expanding the Family Economic Stress Model: Insights From a Mixed-Methods Approach. Journal of Marriage and Family, 70(1), 196-209.

Ricciuto L., Tarasuk, V., \& Yatchew, A. (2006). Socio-demographic influences on food purchasing among Canadian households. European Journal of Clinical Nutrition, 60(6): 778-790. Retrieved from http://www.nature.com/ejcn/index.html

Ritchie, J., \& Lewis, J. (2003). Qualitative research practice: A guide for social science students. London, UK: Sage Publications.

Sayer, A. (1992). Method in social science: A realist approach, $2^{\text {nd }}$ edition. London: Routledge.

Shields, M., \& Shooshatari, S. (2001). Determinants of self-perceived health. Health Reports, 13(1): 35-52. Retrieved from http:/www.statcan.gc.ca/pub/82-003x/4060784-eng.htm

Statistics Canada. (2015). Survey of household spending, 2013. The Daily, January 22. Retrieved from http://www.statcan.gc.ca/daily-quotidien/150122/dq150122beng.htm 
Tarasuk, V. (2009). Health implications of food insecurity. In D. Raphael (Ed.), Social determinants of health: Canadian perspectives (2nd ed.) (pp. 205-220). Toronto: Canadian Scholars Press.

Taylor, S., \& Bogdan, R. (1998). Introduction to qualitative research methods (3rd ed.). New York: John Wiley \& Sons.

Vozoris, N. T., \& Tarasuk, V. S. (2003). Household food insufficiency is associated with poorer health. Journal of Nutrition, 133(1): 120-6. Retrieved from http://jn.nutrition.org/

Weinbach, R. W., \& Grinnell, R. M. (2010). Statistics for social workers (Eighth edition). Boston: Allyn \& Bacon. 


\section{Appendix 2.1. Brief Description of Proposed Research}

The research I am proposing is inspired by the state of the current debate in Canada on income assistance. While a great deal of momentum now exists around the need to increase child benefits and to reward work, there is virtually no appetite amongst policy-makers to increase cash benefits to social assistance recipients who are not attached to the labour force. Generating data on this topic could help open and support such a discussion. This is what I would like to do with this small research project.

Based on conversations I've had with both Pat O'Campo and Jim Dunn, my goal would be to identify roughly 20 individuals who are currently in receipt of Ontario Works (OW) and ultimately follow 12-15 of them over an 18-month period, interviewing each one of them a total of 5 or 6 times. It would be my expectation that some of the people I'd identify originally would not be able to be followed for the full 18 months. Some might refuse to be interviewed more than once or twice. Others could become ill, go to jail or simply become unreachable. My goal in starting with 20 people would be to "retain" $12-15$ of them for the full 18 months.

One of my goals would be to establish what kinds of things each person is able to regularly buy when on OW, and ultimately compare that with what they are able to buy once they are approved for the Ontario Disability Support Program (ODSP).

Something similar has been done once before, but not in Canada:

- Edin, Kathryn and Laura Lein. 1997. Making Ends Meet: How Single Mothers Survive Welfare and Low-Wage Work (New York: Russell Sage) $320 \mathrm{pp}$.

Edin and Lein's book outlines a methodology for establishing what low-income people spend their money on. Based on Edin and Lein's methodology, I would propose having a total of 5-6 semi structured interviews with 12-15 people over the course of roughly 18 months.

A major goal here would be to contrast what kind of things each person is able to buy while on OW with what each person can buy once on ODSP. It would be my hope to attribute changes seen in purchases before and after ODSP approval to the increased income. My hope is that the results could help inform the future direction of income assistance policy in Canada.

I am a PhD student at Carleton University's School of Public Policy and Administration. My interest in this project stems from my experience as a Toronto community worker where one of my major focuses was on helping my clients acquire more income. 


\title{
Appendix 2.2. Description of Proposed Research
}

\author{
Nick Falvo \\ $\mathrm{PhD}$ Candidate \\ School of Public Policy and Administration \\ Carleton University \\ E-mail:nfalvo@connect.carleton.ca
}

$\underline{\text { Goal }}$

I am undertaking a research project and am requesting the assistance of Toronto Employment and Social Services (TESS) — and specifically the HOPE Clinic - in establishing contact with 20 single, unattached individuals without dependents who are currently in receipt of Ontario Works (OW). These would also be individuals who have a very good chance of being successful in an application for Ontario Disability Support Program (ODSP) benefits over the course of roughly the next 6-12 months.

\section{The Research}

The research project being proposed is inspired by the state of the current debate in Ontario over social assistance. While a great deal of momentum now exists around the need to increase child benefits and to reward work, there is virtually no appetite amongst policy-makers - on either the political or bureaucratic side - to increase cash benefits to single, unattached OW recipients without dependants who are not engaged in gainful employment (Battle, 2001; Mulvale, 2001; Battle, Mendelson and Torjman, 2006; Klassen and Buchanan, 2006; MISWAA, 2006; Ontario, 2008).

The client base of the HOPE Clinic, with its mandate to transition OW recipients to ODSP, is an ideal group from which to recruit potential interview participants. In the past two years, roughly 200 clients per year have been enrolled into the HOPE Clinic. More than half are eventually successful in being approved for ODSP. Of the clients who enrol in the HOPE Clinic, most show very good follow-up and stay in touch with HOPE officials.

My goal would be to ultimately follow 12-15 such individuals over an 18-month period, interviewing each one a total of four to six times during that period. To be sure, I would not expect to be able to follow all 20 of the individuals with whom I initially establish contact for a period of 18 months. Some, upon hearing what would be involved, might decline to participate in the research project beyond an initial telephone 
conversation. Others might not wish to continue after one or two interviews. Still others could fall ill, relocate outside Toronto, become incarcerated or simply become unreachable. The goal would therefore be to start with 20 but remain engaged with 12-15 over the course of the 18 months. These would all be in-person interviews in Toronto, and my goal would be to travel to Toronto for two weekends per month during the 18month period. Interviews would take place at the preferred location of the interview subject and would last approximately 90 minutes each. Interview participants would be paid an honorarium in line with the expected interview time (likely in the range of \$25$\$ 50$ per interview). Funding for the proposed research project-notably, my travel to and from Toronto, a local telephone and honoraria for interview participants-would amount to a total of roughly $\$ 10,000$. This funding would be sought via a grant proposal to the Canadian Institutes of Health Research.

My goal would be to establish what kinds of purchases each person is able to make on a monthly basis. And in the cases where the person successfully makes the transition to ODSP, my goal would be to compare what purchases are made on a monthly basis while on OW with what purchases are made while on ODSP. One advantage of looking at this particular sub-sample of individuals is that single, unattached adults without dependents see the greatest percentage increase in monthly income of any household type upon transitioning from OW to ODSP. Indeed, such an individual sees her or his monthly benefits increase from $\$ 572$ to $\$ 1,020$, representing a 78 percent increase. This would therefore allow for a higher likelihood of there being an observable difference in monthly purchases.

I would like to use a methodology similar to that used by Edin \& Lein (1997), who undertook a similar study in the United States. I would therefore propose having five to six semi-structured, in-person interviews with each person. According to Edin and Lein, there are several advantages to having multiple interviews. First, it would allow me to gain trust over time, which would allow for more accurate information. Second, it would allow me to better understand and interpret information. Third, individuals who are unclear about their spending habits during the first interview would keep better track of their expenses in future months in order to "give a more precise accounting of their budget the second or third time around" (Edin \& Lein, 1997, p. 14).

Following Edin \& Lein's methodology, I propose gathering basic background information during the first interview. In subsequent interviews, I would collect "detailed income and expenditure data" (Edin \& Lein, 1997, p. 14). I would seek to use the following approach used by Edin \& Lein: 
We first asked respondents to estimate expenditures during the previous month. We then asked how much these monthly amounts had varied over the previous month. We then asked how much these monthly amounts had varied over the previous twelve months. Finally, we asked if they had made large one-time purchases during the previous year (VCRs, furniture, appliances, bicycles, and so forth) that were not included in their monthly account (Edin \& Lein, 1997: 14)...After gathering a detailed account of each respondent's monthly expenditures, we asked her to tally her total income...(Edin \& Lein, 1997: 15).

\section{$\underline{\text { Potential Findings }}$}

A small body of research on budgets of very low-income households does exist, with Edin and Lein's (1997) having been considered groundbreaking at the time. Most research on budgets of very low-income households has been confined to households with children, with the vast majority of the North American research being focused on the United States. The proposed research project would be one of the few Canadian studies ever on very low-income spending, possibly the only one ever that looks at reactions to a changed income amongst very low-income households, and certainly the first that looks at the reactions to a changed income for such a specific subsection of social assistance recipients.

The research proposal has no hypothesis per se, as it is an exploratory study. But some of my expected findings are that some individuals, with increased income, will be:

- $\quad$ more likely to acquire a telephone; $;^{37}$

- $\quad$ more likely to purchase fruits, vegetables and milk; ${ }^{38}$

- $\quad$ less likely to visit food banks; and

- more like acquire "better" private-market housing.

As previously mentioned, one goal with this research would be to contrast what kinds of purchases a person makes each month while on OW with what kinds of purchases she or he makes while on ODSP. It would be my goal to attribute at least some

\footnotetext{
${ }^{37}$ Among Streets to Homes clients, those on ODSP are far more likely to have a telephone than those on OW (Falvo, 2008: 34).

${ }^{38}$ Quantitative research demonstrates a direct relationship between a household's income level and its purchase of foods from all groups, particularly fruit, vegetables and milk. The relationship is especially strong in households where the annual income is below $\$ 15,000$ (Ricciuto, Tarasuk and Yatchew, 2006).
} 
of the changes in purchases to the increased monthly income. My ultimate hope would be that the research findings could help lead to policy changes that entail increases in cash benefits to this subsection of social assistance recipients, be it in the form of:

- $\quad$ an increase to the Basic Needs component of OW ;

- $\quad$ an increase to the Shelter Allowance component of OW;

- $\quad$ reform of special-diet allowance guidelines;

- $\quad$ reform of ODSP guidelines;

- a new rent supplement program; or

- the creation of a non-refundable tax credit.

Given that the focus of this proposed research is a sub-sample of social assistance recipients in Ontario, the research findings have the greatest likelihood of informing policy in the province of Ontario. Of course, they also have the potential to inform policy-making in other Canadian jurisdictions. In light of the fact that there are currently roughly 50,000 single adults on OW in Toronto, and another 100,000 province-wide, policy changes along the above lines could potentially impact a significant number of low-income Ontarians.

\section{$\underline{\text { Dissemination }}$}

This proposed research project is one of three essays being proposed for my threeessay doctoral dissertation, with each essay focusing on one aspect of income assistance for low-income Canadians. Another essay will be a historical essay on cash benefits to children. Yet another will be an econometric analysis of the impact on work incentive of British Columbia's 2007 increase in social assistance rates.

I would propose that a small advisory board be established to guide the potential dissemination of research results beyond my dissertation-that is, to public audiences, including on both the political and bureaucratic side of the policy-making process. The advisory committee's members could consist primarily of TESS officials, and I would propose to meet with its members on a quarterly basis. I would inform the advisory board on my progress, discuss process and logistics, advise its members on the extent to which I am receiving cooperation from interview participants, and ask members if they have concerns.

Ultimately, I would hope that research findings from this proposed project could inform the thinking of the bureaucracy by being referenced in background papers, especially within Ontario's Ministry of Community and Social Services (MCSS). A major success would be to have findings from this research both inform - and be directly 
referenced in — submissions made to cabinet committees and then, ideally, to Cabinet itself.

\section{$\underline{\text { Contacting Clients }}$}

I do understand and accept that, in light of provincial privacy legislation, I cannot initiate contact with the individuals in question. Rather, based on my 9 October 2009 meeting with TESS officials, I understand that clients would be invited in a letter from TESS to contact me via telephone at a local number. I suggest that approximately 60 such letters initially be written. The letters in question would make it explicit to clients that I have no institutional connection to TESS and that their confidentiality would be assured. Obviously, one of my major goals is to emphasize to interview participants that their identity would not be revealed to TESS officials. Further details with respect to recruitment can be worked out within the next two months.

\section{Qualifications of Primary Investigator}

Though I am currently a PhD candidate in Carleton's School of Public Policy and Administration, I worked for one decade (1998-2008) as a front-line community worker in Toronto. For three years (1999-2001), I worked as an employment support worker primarily with single, unattached adults without dependents at an employment program, funded by Human Resources and Skills Development Canada, and operated by Dixon Hall. And from 2001 until 2008, I worked as a mental health outreach worker at Street Health, during which time one of my major responsibilities was to support clients in their transition from Ontario Works OW to ODSP. This front-experience is relevant to the proposed research for two main reasons. First, it has inspired me to write policy-relevant doctoral research that could potentially lead to increased cash benefits for single, unattached individuals without dependents who are both living on OW and who have no realistic prospect for gainful employment. Second, it has made me both well-suited and well-trained to ask questions of a sensitive nature to a vulnerable population.

\section{Supervision}

The research in question would be supervised primarily by Dr. Patricia O'Campo, a social epidemiologist with 20 years of community-partnered research experience with very low-income populations. Her research includes welfare analyses. Though Dr.

O'Campo is based in Toronto-where she is Director of the Centre for Research on Inner City Health, at St. Michael's Hospital—, she has agreed to be a member of my doctoral dissertation committee. The other committee members are Dr. Saul Schwartz (School 
of Public Policy and Administration, Carleton University) and Dr. Allan Moscovitch (School of Social Work, Carleton University).

\section{$\underline{\text { Next Steps }}$}

Moving forward, my hope would be to have ethics approval by December 2009, which would potentially allow me to begin pilot interviews with clients during the upcoming holiday season. Pilot interviews would allow me to see what sections of my interview guide work and what sections do not. Based on the results of the pilot interviews, I would make revisions to my interview guide and communicate my initial findings to both the proposed advisory committee and to my dissertation committee.

\section{Bibliography}

Battle, Ken. 2001. Relentless Incrementalism: Deconstructing and Reconstructing Canadian Income Security Policy (Ottawa: Caledon Institute of Social Policy, September).

, Michael Mendelson and Sherry Torjman. 2006. Towards a New Architecture for Canada's Adult Benefits (Ottawa: Caledon Institute for Social Policy, June).

Edin, Kathryn and Laura Lein. 1997. Making Ends Meet: How Single Mothers Survive Welfare and Low-Wage Work (New York: Russell Sage).

Falvo, Nick. 2008. "The 'Housing First' Model: Immediate Access to Permanent Housing." Canadian Housing Special Edition: 32-35.

Klassen, Thomas R. and Dan Buchanan. 2006. "Ideology, Policy, and Economy: Liberal, New Democratic and Conservative Reforms of Ontario's Welfare Program" Journal of Canadian Studies Vol. 40 No. 3 Fall: 186-210.

MISWAA. 2006. Time for a Fair Deal: Report of the Task Force on Modernizing Income Security for Working-Age Adults (Toronto: St. Christopher House and Toronto City Summit Alliance) May.

Mulvale, James P. 2001. Reimagining Social Welfare: Beyond the Keynesian Welfare State (Aurora: Garamond Press).

Ontario. 2008. Breaking the Cycle: Ontario's Poverty Reduction Strategy.

Ricciuto L., V. Tarasuk, and A. Yatchew. 2006. "Socio-demographic Influences on Food Purchasing Among Canadian Households." European Journal of Clinical Nutrition Vol. 60, No. 6: 778-790. 


\section{Appendix 2.3. Interview Guide}

\section{Lead-In}

What is your living situation (i.e., shelter, renting a room)?

How do you like this neighbourhood? Is it quiet?

How are your neighbours?

\section{Food}

It must be hard to get decent food every day. How do you manage?

Do you get food at food banks? If yes, which ones?

What kinds of food shopping strategies do you use?

Do you buy fast food?

Roughly how much money per week/month do you spend on food?

Roughly how much money per week/month do you spend on fruit and vegetables?

What kind of food consumes the largest portion of your budget?

What would you say is your biggest problem when it comes to food purchases?

\section{Hypothetical - Food}

If you had $\$ 100$ month in food vouchers (in addition to your regular income), what kind of food would you buy with that extra money?

If food at the grocery store was free, what would food would you buy each month? 


\section{Non-Food}

What else would you buy at the store other than food?

-toothpaste/mouthwash?

-razors/shaving lotion?

-soap?

-shampoo?

-hairspray?

-make-up?

-deodorant?

-toilet paper?

-Q-Tips?

-Band-Aids?

-Aspirin/Tylenol/Advil?

-Cough/cold medicine?

\section{Cleaning Supplies}

-Dish detergent?

-disinfectant?

-floor cleaner?

-oven cleaner?

-other cleaning products?

-coin-operated clothes washer/dryer?

What kinds of cleaning products do you spend the most on?

What's your biggest problem in purchasing cleaning products?

\section{Housing}

How long have you lived in this housing unit (or shelter)?

What do you think about living here?

How much do you pay per month in rent (if applicable)?

-Hydro?

-Property insurance?

Best thing about living in this unit?

Worst thing about living in this unit?

\section{Financial Institutions}

-Interest/Fees on payday loans?

-Fees for cheque cashing?

-NSF charges?

-Monthly banking fees?

-Credit card payments 


\section{Personal Loans}

-Paying back loans to family members?

-Paying back loans to friends?

-Paying back loans to girlfriend or boyfriend?

-Paying back loans to workers?

-Paying back loans to anyone else? 
Identification Costs (including renewals)

-Driver's Licence

-Citizenship Card

-Passport

-Permanent Residence Card

-Non-Canadian Birth Certificate

\section{Transportation}

-TTC

-Taxis

\section{Medical}

-Eyeglasses

-Contact lenses

-Any other medical expenses?

\section{Telecommunications}

-Land line?

-Cell phone

-Voice mail service

-Internet connection/provider

-Computer

-Telephone (the phone itself)

-Cable

-Television (the set itself)

-I-Phone

\section{Entertainment}

-Stereo

-DVDs, CDs, music downloading

-Going out to movies

-Lottery

-Gambling

-Other entertainment

\section{Other Expenses}

-Cigarettes/tobacco

-Alcohol

-Drugs

-Jewellery 


\section{Material Hardship}

-Has there ever been a time when you needed food but could not afford to buy it? When was the last time that happened to you?

-Have you gone hungry because you could not afford to buy food? When was the last time that happened to you?

\section{Clothing}

$-\$ \$$ ?

-Haircuts?

\section{Hypothetical - General}

-What would you do with $\$ 100$ extra today?

-What would you do with $\$ 400$ extra today?

-What do you think you would do with $\$ 100$ extra per month, every month?

-What do you think you would do with $\$ 400$ extra per month, every month?

\section{Conclusion}

-How would you describe/sum up your situation? 


\section{Appendix 2.4.}

Table 2.3

Monthly Expenses by Category (in Dollars)

\begin{tabular}{|c|c|c|c|c|c|}
\hline & $\mathrm{I1}$ & 13 & 14 & 18 & Average \\
\hline Food & $98 \rightarrow 250$ & $150 \rightarrow 250$ & $60 \rightarrow 250$ & $275 \rightarrow 500$ & $146 \rightarrow 313$ \\
\hline Fruit and Vegetables & $10 \rightarrow 50$ & $20 \rightarrow 60$ & $9 \rightarrow 25$ & $60 \rightarrow 80$ & $25 \rightarrow 54$ \\
\hline Housing & $850 \rightarrow 464$ & $115 \rightarrow 134$ & $117 \rightarrow 117$ & $375 \rightarrow 375$ & $364 \rightarrow 273$ \\
\hline Personal Products & $22 \rightarrow 61$ & $35 \rightarrow 64$ & $51 \rightarrow 54$ & $0 \rightarrow 31$ & $27 \rightarrow 53$ \\
\hline Household Products & $0 \rightarrow 33$ & $6 \rightarrow 14$ & $10 \rightarrow 21$ & $4 \rightarrow 24$ & $5 \rightarrow 23$ \\
\hline Financial Services & $135 \rightarrow 172$ & $11 \rightarrow 26$ & $15 \rightarrow 16$ & $5 \rightarrow 24$ & $42 \rightarrow 60$ \\
\hline Gifts & $100 \rightarrow 0$ & $0 \rightarrow 80$ & $45 \rightarrow 75$ & $0 \rightarrow 90$ & $36 \rightarrow 61$ \\
\hline Telephone & $60 \rightarrow 77$ & $3 \rightarrow 3$ & $30 \rightarrow 30$ & $0 \rightarrow 0$ & $23 \rightarrow 28$ \\
\hline Transportation & $0 \rightarrow 171$ & $12 \rightarrow 13$ & $45 \rightarrow 78$ & $125 \rightarrow 75$ & $46 \rightarrow 84$ \\
\hline Clothing & $0 \rightarrow 50$ & $0 \rightarrow 55$ & $235 \rightarrow 140$ & $100 \rightarrow 25$ & $84 \rightarrow 68$ \\
\hline Entertainment & $15 \rightarrow 153$ & $50 \rightarrow 25$ & $45 \rightarrow 86$ & $34 \rightarrow 22$ & $36 \rightarrow 72$ \\
\hline Cigarettes & $75 \rightarrow 100$ & $90 \rightarrow 120$ & $40 \rightarrow 165$ & $60 \rightarrow 50$ & $66 \rightarrow 109$ \\
\hline Alcohol & $40 \rightarrow 0$ & $85 \rightarrow 160$ & $25 \rightarrow 200$ & $250 \rightarrow 100$ & $75 \rightarrow 115$ \\
\hline Drugs & $100 \rightarrow 0$ & $20 \rightarrow 40$ & $175 \rightarrow 250$ & $600 \rightarrow 200$ & $234 \rightarrow 123$ \\
\hline Sex & 0 & $0 \rightarrow 10$ & - & $100 \rightarrow 100$ & $25 \rightarrow 28$ \\
\hline Union Dues & 0 & $0 \rightarrow 0$ & - & $50 \rightarrow 7$ & $13 \rightarrow 2$ \\
\hline Miscellaneous & $60 \rightarrow 15$ & $0 \rightarrow 0$ & - & $70 \rightarrow 0$ & $33 \rightarrow 4$ \\
\hline TOTAL & $1555 \rightarrow 1546$ & $577 \rightarrow 994$ & $848 \rightarrow 1482$ & $2,048 \rightarrow 1,632$ & $1,257 \rightarrow 1,414$ \\
\hline
\end{tabular}

Note. Figures above are only for interview subjects who completed all six interviews and who made the transition from OW to ODSP. Food includes store-bought groceries, fast food, take-out food, and food purchased in a restaurant. Personal Products includes toothbrushes, toothpaste, mouthwash, razors, shaving lotion, soap, shampoo, deodorant, toilet paper, Q-tips, Band-Aids, over-thecounter cold/pain medication, coin-operated laundry machines, laundry detergent, fabric softener, haircuts, eyeglasses. Household Products include dish detergent, disinfectant, floor cleaner, Windex, toilet bowl cleaner, oven cleaner, rags, scrub pads, clothes, mop heads, air freshener, pots, pans, cutlery, dishes and bedding. Financial Services include monthly banking fees, ATM fees (at other fin institutions), cheque cashing, overdraft fees and credit card payments. Gifts refer to gifts to friends, family, boyfriends and girlfriends. Telephone includes cell phone, land phone and voice mail services. Transportation includes public transit, taxis, bicycle purchases and bicycle repairs. Clothing includes shoes. Entertainment includes cable, purchasing and renting CDs/DVDs, going out to movies and purchasing lottery tickets. Alcohol includes alcohol bought at the LCBO, Beer Store and a licensed establishment. Cigarettes include packs of cigarettes, contraband cigarettes, rolling papers and tobacco. Miscellaneous includes private medical insurance, property insurance, fees paid to a chiropractor, art supplies and medication dispensing fee. 
Appendix 2.5.

Table 2.4

Monthly Expenses by Category (as a Percentage of Total Monthly Expenses)

\begin{tabular}{|c|c|c|c|c|c|}
\hline & 11 & 13 & 14 & 18 & Average \\
\hline Food & $4 \rightarrow 16$ & $26 \rightarrow 25$ & $7 \rightarrow 17$ & $13 \rightarrow 31$ & $13 \rightarrow 22$ \\
\hline Fruit and Vegetables & $1 \rightarrow 3$ & $3 \rightarrow 6$ & $1 \rightarrow 2$ & $3 \rightarrow 5$ & $2 \rightarrow 4$ \\
\hline Housing & $55 \rightarrow 30$ & $20 \rightarrow 13$ & $14 \rightarrow 8$ & $18 \rightarrow 23$ & $27 \rightarrow 19$ \\
\hline Personal Products & $1 \rightarrow 4$ & $6 \rightarrow 6$ & $6 \rightarrow 4$ & $0 \rightarrow 2$ & $3 \rightarrow 4$ \\
\hline Household Products & $0 \rightarrow 2$ & $1 \rightarrow 1$ & $1 \rightarrow 1$ & $0 \rightarrow 1$ & $1 \rightarrow 1$ \\
\hline Financial Services & $9 \rightarrow 11$ & $2 \rightarrow 3$ & $2 \rightarrow 1$ & $0 \rightarrow 1$ & $3 \rightarrow 4$ \\
\hline Gifts & $6 \rightarrow 0$ & $0 \rightarrow 8$ & $1 \rightarrow 5$ & $0 \rightarrow 6$ & $2 \rightarrow 5$ \\
\hline Telephone & $4 \rightarrow 5$ & $1 \rightarrow 0$ & $4 \rightarrow 2$ & $0 \rightarrow 0$ & $2 \rightarrow 2$ \\
\hline Transportation & $0 \rightarrow 11$ & $2 \rightarrow 1$ & $5 \rightarrow 5$ & $6 \rightarrow 5$ & $3 \rightarrow 6$ \\
\hline Clothing & $0 \rightarrow 3$ & $0 \rightarrow 6$ & $28 \rightarrow 9$ & $5 \rightarrow 2$ & $8 \rightarrow 5$ \\
\hline Entertainment & $1 \rightarrow 10$ & $9 \rightarrow 3$ & $5 \rightarrow 6$ & $2 \rightarrow 1$ & $4 \rightarrow 5$ \\
\hline Cigarettes & $5 \rightarrow 6$ & $16 \rightarrow 12$ & $5 \rightarrow 11$ & $3 \rightarrow 3$ & $7 \rightarrow 8$ \\
\hline Alcohol & $3 \rightarrow 0$ & $15 \rightarrow 16$ & $3 \rightarrow 13$ & $12 \rightarrow 6$ & $8 \rightarrow 9$ \\
\hline Drugs & $6 \rightarrow 0$ & $3 \rightarrow 4$ & $21 \rightarrow 17$ & $29 \rightarrow 12$ & $15 \rightarrow 8$ \\
\hline Sex & $0 \rightarrow 0$ & $0 \rightarrow 1$ & 0 & $5 \rightarrow 6$ & $1 \rightarrow 2$ \\
\hline Union Dues & $0 \rightarrow 0$ & $0 \rightarrow 0$ & 0 & $2 \rightarrow 0$ & $1 \rightarrow 0$ \\
\hline Miscellaneous & $4 \rightarrow 1$ & 0 & 0 & $3 \rightarrow 0$ & $2 \rightarrow 0$ \\
\hline
\end{tabular}

Note. Figures above are only for interview subjects who completed all six interviews and who made the transition from OW to ODSP. Food includes store-bought groceries, fast food, take-out food, and food purchased in a restaurant. Personal Products includes toothbrushes, toothpaste, mouthwash, razors, shaving lotion, soap, shampoo, deodorant, toilet paper, Q-tips, Band-Aids, over-the-counter cold/pain medication, coin-operated laundry machines, laundry detergent, fabric softener, haircuts, eyeglasses. Household Products include dish detergent, disinfectant, floor cleaner, Windex, toilet bowl cleaner, oven cleaner, rags, scrub pads, clothes, mop heads, air freshener, pots, pans, cutlery, dishes and bedding. Financial Services include monthly banking fees, ATM fees (at other fin institutions), cheque cashing, overdraft fees and credit card payments. Gifts refer to gifts to friends, family, boyfriends and girlfriends. Telephone includes cell phone, land phone and voice mail services. Transportation includes public transit, taxis, bicycle purchases and bicycle repairs. Clothing includes shoes. Entertainment includes cable, purchasing and renting CDs/DVDs, going out to movies and purchasing lottery tickets. Alcohol includes alcohol bought at the LCBO, Beer Store and a licensed establishment. Cigarettes include packs of cigarettes, contraband cigarettes, rolling papers and tobacco. Miscellaneous includes private medical insurance, property insurance, fees paid to a chiropractor, art supplies and medication dispensing fee. 
Appendix 2.6.

Table 2.5

Monthly Revenue by Category (in Dollars)

\begin{tabular}{|c|c|c|c|c|c|}
\hline & 11 & 13 & 14 & 18 & Average \\
\hline Income Assistance & $607 \rightarrow 1,033$ & $239^{*} \rightarrow 586^{*}$ & $221^{*} \rightarrow 471$ & $88^{*} \rightarrow 648^{*}$ & $289 \rightarrow 685$ \\
\hline Metro Pass Allowance & $122 \rightarrow 121$ & $108 \rightarrow 121$ & $121 \rightarrow 121$ & $121 \rightarrow 79$ & $118 \rightarrow 111$ \\
\hline Special Diet Allowance & $250 \rightarrow 84$ & $92 \rightarrow 92$ & $21 \rightarrow 167$ & $96 \rightarrow 98$ & $115 \rightarrow 110$ \\
\hline Diabetic Supplies & $45 \rightarrow 108$ & & & & \\
\hline Tax Credits & $69 \rightarrow 40$ & $43 \rightarrow 62$ & $40 \rightarrow 69$ & $90 \rightarrow 54$ & $61 \rightarrow 56$ \\
\hline Gifts & $35 \rightarrow 0$ & 0 & $40 \rightarrow 0$ & $50 \rightarrow 0$ & $31 \rightarrow 0$ \\
\hline Income from Hidden Economy & $220 \rightarrow 100$ & 0 & $110 \rightarrow 175$ & $15 \rightarrow 0$ & $86 \rightarrow 71$ \\
\hline Returning Empties & $30 \rightarrow 0$ & $4 \rightarrow 10$ & 0 & $10 \rightarrow 150$ & $11 \rightarrow 40$ \\
\hline Honoraria for Research & $40 \rightarrow 40$ & $40 \rightarrow 0$ & $50 \rightarrow 0$ & 0 & $33 \rightarrow 10$ \\
\hline Casual Labour & $0 \rightarrow 0$ & $32 \rightarrow 0$ & $150 \rightarrow 100$ & $1,050 \rightarrow 0$ & $308 \rightarrow 25$ \\
\hline Panhandling & 0 & 0 & 0 & $15 \rightarrow 0$ & $4 \rightarrow 0$ \\
\hline TOTAL & $1,418 \rightarrow 1,526$ & $558 \rightarrow 871$ & $753 \rightarrow 1,103$ & $1,535 \rightarrow 1,029$ & $1066 \rightarrow 1132$ \\
\hline
\end{tabular}

Note. Figures above are only for interview subjects who completed all six interviews and who made the transition from OW to ODSP. Income Assistance refers to portion for rent and basic needs combined. Other amounts listed directly below are supplementary (i.e. additional) amounts. Tax Credits include revenue from income-tax returns, the GST credit and the HST credit. Income from Hidden Economy includes the sale of cigarettes, prescription medication, illicit drugs, coats, shoes, boots and TTC tokens. It also includes 'renting' floor/sofa to 'guest.' Honoraria for Research does not include honoraria for the present study. Casual Labour includes cash jobs and selling scrap metal.

*Income Assistance in these cases does not include rent paid directly by OW/ODSP to landlord. 
Appendix 2.7.

Table 2.6

\section{Monthly Revenue by Category (as a Percentage of Total Monthly Revenue)}

$\begin{array}{lccccc} & 11 & 13 & 14 & 18 & \text { Average } \\ & & & & & \\ \text { Income Assistance } & 43 \rightarrow 68 & 43^{*} \rightarrow 67^{*} & 29^{*} \rightarrow 43 & 6^{*} \rightarrow 63^{*} & 30 \rightarrow 60 \\ \quad \text { Metro Pass Allowance } & 9 \rightarrow 8 & 19 \rightarrow 14 & 16 \rightarrow 11 & 8 \rightarrow 8 & 13 \rightarrow 10 \\ \quad \begin{array}{l}\text { Special Diet Allowance } \\ \text { Diabetic Supplies }\end{array} & 18 \rightarrow 6 & 16 \rightarrow 11 & 3 \rightarrow 15 & 6 \rightarrow 10 & 11 \rightarrow 11 \\ & 3 \rightarrow 7 & & & & \\ \text { Tax Credits } & 5 \rightarrow 3 & 8 \rightarrow 7 & 5 \rightarrow 6 & 6 \rightarrow 5 & 6 \rightarrow 5 \\ \text { Gifts } & 2 \rightarrow 0 & 0 & 5 \rightarrow 0 & 3 \rightarrow 0 & 3 \rightarrow 0 \\ \text { Income from Hidden } & 16 \rightarrow 7 & 0 & 15 \rightarrow 16 & 1 \rightarrow 0 & 8 \rightarrow 6 \\ \text { Economy } & 2 \rightarrow 0 & 1 \rightarrow 1 & 0 & 1 \rightarrow 15 & 1 \rightarrow 4 \\ \text { Returning Empties } & 3 \rightarrow 3 & 7 \rightarrow 0 & 7 \rightarrow 0 & 0 & 4 \rightarrow 1 \\ \text { Honoraria for Research } & 0 \rightarrow 0 & 6 \rightarrow 0 & 20 \rightarrow 9 & 68 \rightarrow 0 & 24 \rightarrow 2 \\ \text { Casual Labour } & 0 & 0 & 0 & 1 \rightarrow 0 & 0 \rightarrow 0\end{array}$

Note. Figures above are only for interview subjects who completed all six interviews and who made the transition from OW to ODSP. Income Assistance refers to portion for rent and basic needs combined. Other amounts listed directly below are supplementary (i.e. additional) amounts. Tax Credits include revenue from income-tax returns, the GST credit and the HST credit. Income from Hidden Economy includes the sale of cigarettes, prescription medication, illicit drugs, coats, shoes, boots and TTC tokens. It also includes 'renting' floor/sofa to 'guest.' Honoraria for Research does not include honoraria received for the present study. Casual Labour includes cash jobs and selling scrap metal.

*Income Assistance in these cases does not include rent paid directly by OW/ODSP to landlord. 
Appendix 2.8.

Table 2.7

Results of SF-36v2 Health Survey

\begin{tabular}{lllll}
\hline & \multicolumn{2}{l}{ First Administration } & \multicolumn{2}{l}{ Second Administration } \\
\hline & $\begin{array}{l}\text { Physical } \\
\text { Health }\end{array}$ & Mental Health & $\begin{array}{l}\text { Physical } \\
\text { Health }\end{array}$ & Mental Health \\
Informant 1 & $32(\mathrm{OW})$ & $50(\mathrm{OW})$ & 30 (ODSP) & $42(\mathrm{ODSP})$ \\
Informant 2 & $62(\mathrm{OW})$ & $27(\mathrm{OW})$ & $58(\mathrm{OW})$ & $44(\mathrm{OW})$ \\
Informant 3 & $41(\mathrm{OW})$ & $30(\mathrm{OW})$ & $37(\mathrm{ODSP})$ & 31 (ODSP) \\
Informant 4 & $51(\mathrm{OW})$ & $61(\mathrm{OW})$ & $59(\mathrm{ODSP})$ & 38 (ODSP) \\
Informant 5 & $45(\mathrm{OW})$ & $56(\mathrm{OW})$ & & \\
Informant 6 & $47(\mathrm{OW})$ & $24(\mathrm{OW})$ & & \\
Informant 7 & $59(\mathrm{OW})$ & $58(\mathrm{OW})$ & & 37 (ODSP) \\
Informant 8 & $50(\mathrm{OW})$ & $44(\mathrm{OW})$ & $57(\mathrm{ODSP})$ & \\
Informant 9 & $40(\mathrm{OW})$ & $38(\mathrm{OW})$ & & \\
Informant 10 & $38(\mathrm{OW})$ & $24(\mathrm{OW})$ & $40(\mathrm{OW})$ & 14 (OW) \\
\hline
\end{tabular}

Note. A score of 50 is the United States average. Higher scores reflect better health; lower scores reflect worse health. Blank spaces in fifth and sixth columns indicate that informant did not complete a second administration. 


\section{Appendix 2.9. Deviations From Original Plan}

There were three main deviations from the original 'plan of action' conceived for this research study. They are as follow:

\section{AHCS Study}

Before contact was made with City of Toronto officials, informal contact had been made with researchers involved with the At Home/Chez Soi (AHCS) random control trial (a project of the Mental Health Commission of Canada). With several hundred low-income research participants involved with the Toronto component of that study, I was interested in 'piggy backing' onto it and asking certain participants budgeting questions. The participants would have already been recruited, and most would be following up frequently. Principal Investigators involved with the AHCS study discussed this possibility via e-mail, but ultimately steered the researcher away from this idea for several reasons. First, it was expected that most AHCS participants would be accessing ODSP benefits within two to three weeks of enrolment in the AHCS study. This would have made it extremely challenging for me to have conducted three interviews with each participant before they transitioned to ODSP. Second, AHCS participants were homeless on enrollment, and this would have introduced further complications. For example, OW recipients who are homeless do not receive the housing component of OW. Further, a person asked about monthly budgeting while homeless and then while housed would likely report budgeting changes that reflect their change in housing status rather than simply a change in their income levels. Thus, several research suggested that I contact City of Toronto officials about the possibility of interviewing Project HOPE clients. 


\section{Women vs. Men}

Initially, there was no plan to interview men only. However, as discussed in detail in the Methods section of the present essay, there were several reasons for eventually deciding to interview men only. These reasons will not be repeated here.

\section{Funding From a Granting Council}

After City of Toronto officials confirmed they would assist with the research, Dr. O'Campo and I applied for funding to the Canadian Institutes of Health Research (CIHR). In principle, a CIHR operating grant would have covered the honoraria and transit tokens for each of several dozen participants, as well as my travel costs between Ottawa and Toronto. However, after two unsuccessful funding applications to CIHR, it was decided that the study would make do with seed funding provided by Dr. O'Campo. This limited the sample size to 10 . 


\section{Appendix 2.10. City of Toronto Letter of Support}

Date: Mon, 04 Jan 2010 16:57:02

From: "Joe T. Manion" <jmanion@toronto.ca>

To: "Nicholas Falvo" < nfalvo@connect.carleton.ca $>$

Subject: Nic, in response to you call, I have put together the following for your use.

Nic, in response to you call, I have put together the following for your use.

As the Director responsible for research and policy and Toronto and Employment Services, I, and a number of other TESS staff, met with Nick on a number of occasions to discuss his research proposal, its objectives and outcomes and the potential role TESS could play to facilitate the project. I believe the research can provide valuable information about important real world outcomes related to differences in allowances received by recipients of different social assistance programs, and shed additional light on the implications of those differences for peoples's health and welfare.

Our primary role would be straightforward: to provide a means by which homeless Ontario Works clients could, if they so chose, initially connect with Nick to receive information about and potentially participate in his research. We have undertaken this role in various types of research involving OW clients, always ensuring that client confidentiality and privacy is protected. In the context of the study, we would have no further contact with any clients, and indeed would not know which clients have agreed to participate.

We will of course be interested in the findings, as to my knowledge this specific type of research has not been undertaken elsewhere in Canada.

"This e-mail may be privileged and/or confidential, and the sender does not waive any related rights and obligations. Any distribution, use, or copying of this e-mail or the information it contains by anyone other than the intended recipient(s) is unauthorized and may breach the provisions of the Municipal Freedom of Information and Protection of Privacy Act. If you received this e-mail in error, please advise me by return e-mail, or contact me at 416-397-0788 immediately." 


\section{Appendix 2.11. Letter From City of Toronto to Potential Interview Subjects}<smiles>[AlH2]</smiles>

DATE

Dear

Nick Falvo, a researcher at Carleton University in Ottawa, is starting a major research project in the next month. He is interested in talking to people who are receiving social assistance in Toronto and who are currently enrolled in the Hope Clinic.

Toronto Employment and Social Services has agreed to assist Nick by asking some people currently in the Hope Clinic program if they want to speak to him about his study.

The attached flyer from Nick talks about the study.

- If you decide to take part in the study, or want more information, please phone the telephone number on the flyer provided by Nick. You do not have to talk to or phone your caseworker.

- If you decide you do not want to take part in the project, you do not have to do anything.

Taking part in the study will not affect your eligibility for social assistance in any way. If you do take part, Nick will not share with Toronto Employment and Social Services (TESS) any information that you provide that could identify you personally. TESS will not even know if you do agree or not to participate in his study.

Thank you for your time.

Regards,

Joe Manion

Director of Strategic Program Development

Toronto Employment and Social Services 
Appendix 2.12. Flyer Given to Potential Interview Subjects

\section{Study participants needed \\ Earn $\$ 25$ cash per interview}

We are looking for men over 18 years of age to take part in a study on nutrition, income and expenses

- Up to 6 in-person confidential interviews

- \$25 cash for each interview

- Meet at a convenient place/time for you

For more information, please contact Nick at 647986-7855 
Appendix 2.13. Letter of Information

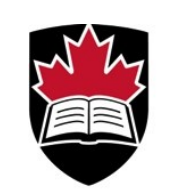

\section{Carleton}

U N I V E R S I T Y

Canada's Capital University

\section{Letter of Information to \\ Participate in a Research Study}

Study Title: Monthly Purchases of Social Assistance Recipients

Study Lead Investigator: $\quad$ Mr. Nick Falvo, PhD Candidate

Carleton University

Ottawa, Ontario

Telephone: 647-986-7855 (during business

hours)

Study

Investigator/Supervisor:

Study Co-

Investigator/Collaborator:

(St. Michael's Hospital

Principal Investigator)
Co- Dr. Saul Schwartz

Professor, School of Public Policy and

Administration

Carleton University

Ottawa, Ontario

Telephone: 613-520-2600, ext. 2542 (during

business hours)

Dr. Patricia O'Campo

Director, Centre for Research on Inner City

Health

St. Michael's Hospital

Toronto, Ontario

Telephone: 416-864-6060, ext. 3312 (during

business hours)

\section{Funding Support:}

Centre for Research on Inner City Health

You are being asked to consider taking part in a research study about monthly purchases of people receiving social assistance. Before agreeing to participate in this study, it is important that you read this letter of information. It includes details we think you need to know in order to decide if you wish to take part in the study. If you have any questions about the study, please ask the study lead investigator, Mr. Nick Falvo. You may also choose to discuss the study with someone else, such as a family member or close friend. You should make sure that you are given sufficient time to read this letter of information and sufficient time to decide if you wish to participate in this study. You should also make sure that any questions you have are answered to your satisfaction before agreeing to participate in this study. All research is voluntary. 


\section{Background and Purpose of the Study}

Very little is known about how those on social assistance are able to meet their financial obligations. For example, it is not known exactly how much the monthly allowance for those in the Ontario Works (OW) program falls short of monthly needs. Also, no research has been done to see how an individual's budgeting changes once the transition is made from Ontario Works (OW) to Ontario Disability Support Program (ODSP). Finally, there is a lack of attention right now to the need to raise the rates for single individuals without dependents.

This study will look at what kinds of purchases very low income individuals make on a monthly basis. The study also aims to compare what purchases individuals make on OW benefits with those that they make once they start receiving ODSP benefits.

\section{Description of the Study}

If you agree to participate in this study, you will be interviewed between one and six times over an 18-month period. Each interview will take about one hour. Interviews will not be taped, recorded or photographed. The study lead investigator/interviewer will take hand-written notes which will later be typed up. The interviewer will also ask you questions about your physical and emotional health and well-being and fill out a questionnaire of your responses. This questionnaire will take about 10 minutes to complete and will be administered at two of the interview sessions, over the 18-month period.

The interview questions are quite personal, including questions about your sources of income, and what you spend your money on. The questionnaire includes questions about how you feel and how things have been with you. It is possible that some questions in the interview or in the questionnaire may make you feel uncomfortable. You may refuse to answer any questions you do not feel comfortable answering. Demographic information (such as your gender and age) will also be used in the study.

Approximately 20 to 30 single males with no dependents, who are enrolled in the Hope Clinic program in Toronto (Toronto Employment and Social Services - TESS) will participate in this study.

\section{Potential Harms and Potential Benefits}

There are no known harms associated with participation in this study. There are also no direct benefits to you for participating in this study. However, we hope that this study will give us valuable information that may help lead to future policy changes with respect to benefits for very low income individuals.

\section{Participation and Withdrawal}

You do not have to participate in this research if you do not want to. However, by agreeing to take part in the study interview and responding to the questions for the questionnaire, you are consenting to participate in this research study. Your decision to participate, or not participate, or to withdraw from participation will not have any effect on your OW or ODSP benefits or your involvement in the Hope Clinic program. You may stop your participation in the study at any time. If you withdraw from the study, you may decide if the information you have provided may still be used in the study. You may also request that your information not be used and that it be destroyed. 


\section{Potential Costs and Reimbursement}

There will be no charges or costs to you for your participation in this study. For each interview session you take part in, you will be reimbursed $\$ 25$ cash for your time. You will also be given 2 transit tokens at each session to reimburse you for travel costs. Meals may also be provided (for example, if the session takes place during a designated meal time for you).

\section{Confidentiality and Privacy}

Your interview and questionnaire answers/information (data) collected from you in the study will be kept confidential. This data will be coded with a study number and will not contain your name nor other identifying information. The study lead investigator is in control of the study code key, which is needed to connect your name and other identifying information collected to the other information (data) collected from you. Your name and other identifying information collected from you will be securely stored separately from your coded data. Information collected on paper forms will be securely stored in locked filing cabinets. Information collected that is stored on the computer or portable electronic devices will be in files that are coded. It is important to understand that despite these protections being in place, there continues to be the risk of unintentional release of identifying information. The investigators will protect your records and keep all the information in your study file confidential to the greatest extent possible. Thus the chance that this information will be accidentally released is small. The information collected from you in the study will be securely stored for a maximum of 5 years after the study is completed, and then this information will be securely destroyed. The only people who may see your name or other identifying information collected are the study investigators and the Carleton University Research Ethics Board and the St. Michael's Hospital Research Ethics Board. These Research Ethics Boards may look at study records, including your name, for the purpose of monitoring the study. We, the investigators, will never give out your name or other identifying information to anybody else unless otherwise required by law. Please be advised that if a study investigator judges you to be at risk to your safety or to the safety of others, then steps will be taken to help ensure your safety or the safety of others, including dissolving confidentiality as necessary, and enlisting appropriate medical assistance, such as appropriate mental healthcare services.

You should be aware that coded study data may be shared with Toronto Employment and Social Services (TESS) to help facilitate planning and policy development. This coded data shared with TESS will not personally identify you in any way. No information will be shared with TESS with respect to whether or not you are participating in this study.

In no way does participation in this study waive your legal rights nor release the investigators or involved institutions from their legal and professional responsibilities.

\section{Study Results}

The study results will be presented and published as part of Mr. Nick Falvo's PhD thesis. The study results may also be presented at scientific conferences or published in scientific journals. However, you will never be identified individually in any presentation or publication of study results. When the study is completed, you may contact the study 
lead investigator, Mr. Nick Falvo, to request information about study findings. You may also request copies of reports and attend presentations of the findings.

\section{New Findings or Information}

We may learn new things during the study that you may need to know. We can also learn about things that might make you want to stop participating in the study. If so, you will be informed about any such new information in a timely manner.

\section{Study Contacts}

If you have questions about this research study, please contact the study lead investigator, Mr. Nick Falvo at 647-986-7855.

\section{Research Ethics Board Contacts}

If you have any questions about your rights as a research participant, please contact

the Chair, Research Ethics Board, St. Michael's Hospital, at 416-864-6060 ext. 2557, and/or

Leslie MacDonald-Hicks (Research Ethics Coordinator), Carleton University, at 613-5202517

during regular business hours.

You will be given a copy of this letter of information to keep for your records. 


\section{Appendix 2.14. Consent Form}

\section{[TELEPHONE SCRIPT]}

(note, read the text in mixed case, CAPS are instructions)

$$
--
$$

Hi:

Thank you so much for calling!

[OR I AM RETURNING A CALL TO THE RECIPIENT: My name's Nick Falvo. I am a $\mathrm{PhD}$ student at Carleton University. I got your message about wanting to find out more about the project I'm conducting. Is this a good time for us to talk?]

Why don't I begin by telling you a little bit about this study. Very little is known about how those on social assistance are able to meet their financial obligations. It is not known whether and by how much the monthly allowance for those in the Ontario Works program falls short of monthly needs. So, I want to do a study to find out this kind of information. My hope is that the study will give us valuable information that may help lead to future policy changes with respect to benefits for very low income individuals.

I'd like to emphasize that should you be willing to be interviewed, nothing you tell me or indicate that could identify you personally will be reported to OW or the Toronto Employment and Social Services (TESS) or your worker. TESS will not even know if you do agree or not to participate in this study.

This research project has been reviewed by the research ethics boards of both Carleton University, Ottawa, Ontario and St. Michael's Hospital, Toronto, Ontario. It is being supervised by Dr. Saul Schwartz at Carleton University. Dr. Patricia O'Campo, Centre for Research on Inner City Health, St. Michael's Hospital is a study collaborator.

Seed money for the study is being provided by the Centre for Research on Inner City Health. It is hoped that additional funding for the study will also be received from a funding agency.

Do you have any questions? If you're still interested I'd like to ask you a few questions to see if you're eligible for the study. I will be writing down your responses. May I proceed?

1. Do you currently receive Ontario Works?

2. Are you planning to apply for Ontario Disability Support Program (ODSP) benefits through the HOPE Clinic?

3. Are you single with no dependents? 
4. Are you between 18 and 64 years of age?

5. Are you male?

6. Do you understand what I've been saying (i.e., English literacy)?

7. Would you feel comfortable talking to me about how you spend your money?

[IF NO TO ANY OF THE ABOVE QUESTIONS...]

You are not eligible to participate in the study. I do however thank you for your time and interest in the study.

[IF YES TO ALL OF THE ABOVE QUESTIONS...]

You are eligible to participate in the study.

I would really like to interview you at some point in the next few weeks. The interview would last roughly one hour. Interviews will not be taped, recorded or photographed. I would also ask you questions about your physical and emotional health and well-being, and fill out a questionnaire of your responses. The questionnaire would take about 10 minutes to complete and would be administered at two of the interview sessions.

For each interview session you take part in, you will be reimbursed $\$ 25$ cash for your time. In order to get complete information, sometimes I'll do more than one interview. You may be interviewed up to six times over the following 18 months.

I'd like to remind you that what you tell me or indicate in the interview session will be kept confidential. I will not tell your TESS worker that you are participating in this study and will not even write your name beside your answers.

The interview questions are quite personal, including questions about your sources of income, and what you spend your money on. The questionnaire includes questions about how you feel and how things have been with you. It is possible that some questions in the interview or in the questionnaire may make you feel uncomfortable. You have the right to refuse an interview, withdraw from an interview at any time, or to refuse to answer a specific question in the interview or on the questionnaire.

Your name will never appear beside your answers (study data). The study data will have a study code number on it instead of your name. Any personal (identifying) information collected from you (such as your name, address, telephone number) will be securely stored separately from any study data collected. The study information collected will be securely destroyed a maximum of five years after the study is completed. Only myself, my supervisor, Dr. Saul Schwartz, study collaborator, Dr. Patricia O'Campo and the Research Ethics Boards of Carleton University and St. Michael's Hospital will have access to information collected that could identify you personally, unless otherwise required by law. The Research Ethics Boards may look at study records for the purpose of monitoring the study. 
If you decide to withdraw from the study, you may decide at that time that I may use the information you have provided or may request that it be destroyed.

When the results of the research are published, you are welcome and encouraged to obtain copies of reports and attend any presentations of the findings. You may also contact me to request any findings once the study is done.

Are you willing to participate in the study?

[IF YES...] I will be asking you a few more questions. If you provide personal information (such as your name, address, telephone number) I will put this information in a separate file which will be securely stored. May I proceed?

[IF YES ...]

ASSIGN A SUBJECT ID \#. DOCUMENT ON THIS FORM; DOCUMENT ON THE MASTER LINKING LOG.

When is a good time and location for us to meet? IF A PUBLIC PLACE IS GIVEN IT MAY BE DOCUMENTED HERE. IF A HOME ADDRESS IS GIVEN, DOCUMENT ON THE MASTER LINKING LOG.

Can you give me a telephone number where I can reach you in the meantime, should the need arise? DOCUMENT ON THE MASTER LINKING LOG.

Would you like me to mail you the sample questions for the interview right now? Can you give me your full name and address where I can send this information? DOCUMENT ON THE MASTER LINKING LOG (IF INFORMATION NOT ALREADY OBTAINED; SEE ABOVE).

I will give you a 'Letter of Information' about the study when we meet. This letter will provide you with more detailed information about the study. If you decide you do not wish to participate in the study interviews, the personal information collected about you will be securely destroyed.

For verification purposes, what is your age in years?

What is your month and year of birth? DOCUMENT ON THE MASTER LINKING LOG.

If you have any further questions, please contact me at 647-986-7855. 
Appendix 2.15. Follow Up Letter

\section{Carleton \\ U N I V E R S I T Y \\ Canada's Capital University}

\section{Follow Up Letter}

Study Title: Monthly Purchases of Social Assistance Recipients

Dear

I last met with you on

I am writing to update you on the status of this study. I have completed the interview phase of my study and I am currently analyzing the study data. I no longer have a Toronto cell number, but you can still contact me if you have any questions about the study. Feel free to send me an email at nfalvo@connect.carleton.ca. You could also contact:

Dr. Saul Schwartz

Study Co-Investigator/Supervisor

Professor, School of Public Policy and Administration

Carleton University

Ottawa, Ontario

Telephone: 613-520-2600, ext. 2542 (during business hours)

or

Dr. Patricia O'Campo

Study Co-Investigator/Collaborator

St. Michael's Hospital

Principal Investigator

Director, Centre for Research on Inner City Health

St. Michael's Hospital

Toronto, Ontario

Telephone: 416-864-6060, ext. 3312 (during business hours)

Thanks again for your participation.

Regards,

Nick Falvo

PhD Student 


\section{Essay 3: \\ Determinants of Welfare Caseloads for Singles}




\section{Introduction}

The notion that it is ill-advised to pay people to 'do nothing' has existed for centuries. In the western world, it has existed at least since the English Poor Laws in the 1600s. As discussed in Essay 1, it has been a central feature of Ontario's welfare system since the latter's inception and remains a topic of discussion in the current Canadian debate over a 'guaranteed annual income' (Battle, 2008). Yet, in spite of its prevalence in discussions about income assistance-as well as the considerable academic attention it has received in the United States-very few quantitative studies attempting to assess the causal impact of provincial welfare benefit levels on social assistance (SA) caseloads have been undertaken in Canada over the past decade.

The purpose of the present essay is to measure the unique relationships between several independent variables (including provincial welfare benefit levels) on the one hand, and last-resort social assistance caseloads, on the other. By last-resort, I mean "cash or in-kind transfers that aim at preventing extreme hardship and employ a lowincome criterion as the central entitlement condition" (Immervoll, 2009, p. 5). I am not referring to benefits (such as benefits from the Ontario Disability Support Program) geared specifically to individuals deemed unable to work.

I take an aggregate look at six Canadian provinces, over time, using the province as the unit of observation. The analysis examines the relationship between last-resort SA caseloads and a variety of independent variables for the 1989-2010 period. One unique aspect to the present research is its focus on singles. ${ }^{39}$ Undertaking such research in the United States would be very difficult since most singles in the United States are ineligible

\footnotetext{
${ }^{39}$ In the present context, "singles" means single adults without dependents who are considered employable.
} 
for last-resort SA; indeed, in the United States, cash benefits are generally not available to working-age adults without dependents (Moffit, 2003).

The essay will begin by outlining a theoretical framework. It will then assess previous Canadian efforts at estimating the determinants of last-resort SA caseloads. This will be followed by a data section that will include an analysis both of what steps were taken to find caseload data and why it is so difficult for researchers to obtain such information in Canada. Methods will then be discussed, followed by results and a conclusion. 


\subsection{Theoretical Economic Model}

Neoclassical labour economists are concerned with the factors that determine both the supply of labour by workers and the demand for labour by employers. In theorizing about an individual's labour market behaviour, they assume that most individuals aim to maximize their utility (subject to options available). Put differently, labour economists believe that most people, faced with external constraints such as the available time to work, the skills they possess and the jobs available, make optimizing choices that determine the amount of labour they supply.

For the purpose of modelling labour markets, two options are typically assumed to be available to an individual: goods (including services) and leisure (including household work). Each hour in the day can be allocated either to working and earning a wage, or to consuming leisure. In Figure 1, which assumes no welfare system, the slope of the person's indifference curve at any point is the marginal rate of substitution (MRS) - that is, the amount of leisure the consumer is willing to accept in exchange for giving up a unit of goods and services, holding utility constant (Benjamin, Gunderson, Lemieux, \& Riddell, 2007, p. 41). The slope of the budget constraint reflects the individual's wage rate, indicating the income that is gained when an hour of leisure is given up — thus, a steeper budget line implies a higher wage rate. ${ }^{40}$ The tangency between the indifference curve and the budget line is the consumer's optimal choice, as the point of tangency represents the highest level of utility that the individual can attain with a given wage rate.

\footnotetext{
${ }^{40}$ For illustrative purposes, Figure 3.1 assumes a wage rate of 1.
} 


\section{Figure 3.1: Constrained Utility Maximization}

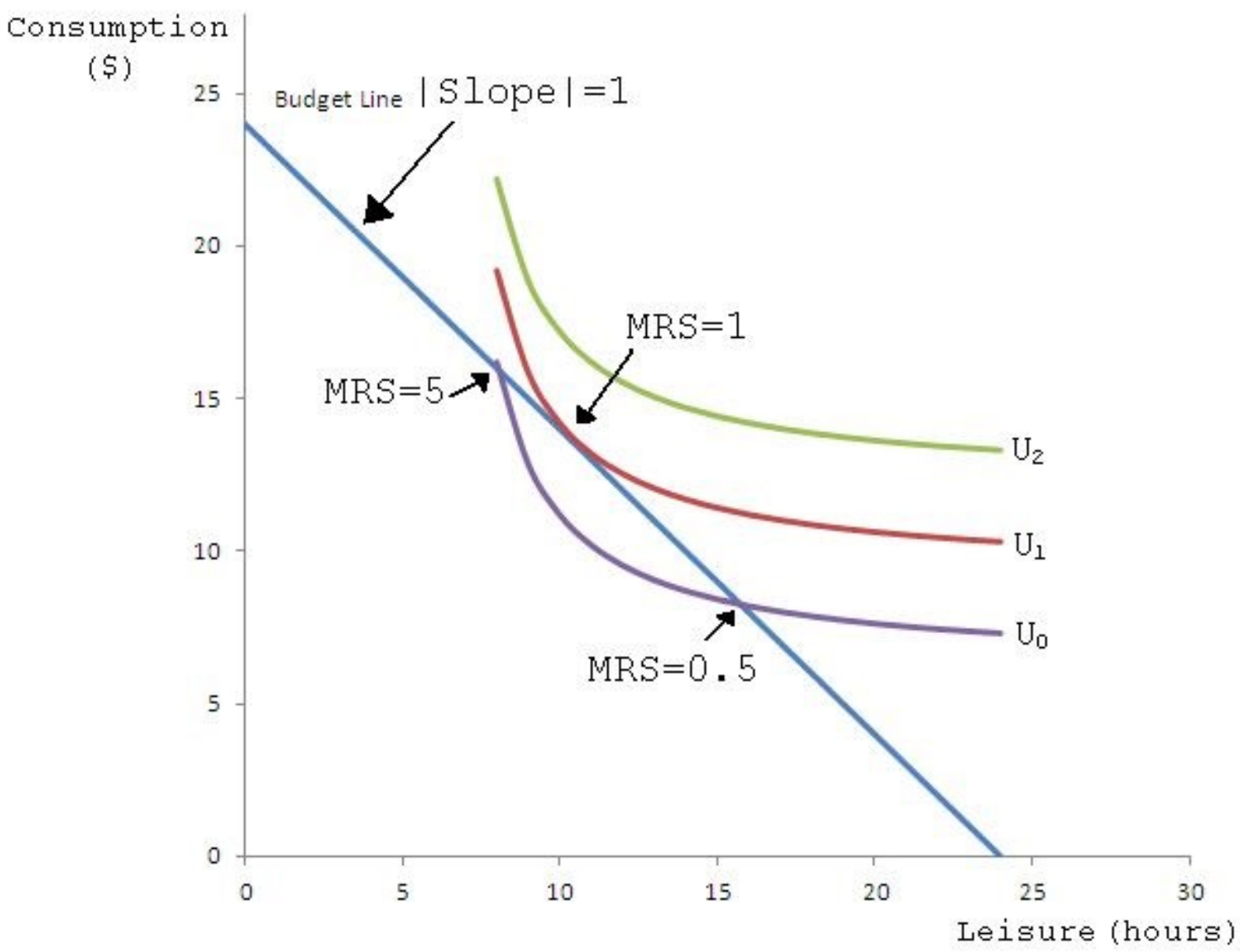

Figure 3.2 introduces a last-resort social assistance system. As with Figure 3.1, the slope of the person's indifference curve, at any point, is the MRS. Figure 3.2 illustrates the introduction of a SA program that provides a lump-sum transfer to the individual. This is shown by an outward, parallel shift of the budget constraint. The blue line represents the base case (with $Y_{N}$ representing non-wage income in the absence of a welfare system) and the red line shows an increase in the lump-sum transfer to a higher level. The point of tangency between the budget constraint and the indifference curve again corresponds to the individual's optimal bundle of income and leisure. Assuming that leisure is a normal good, the new point of tangency (B) will imply an increase in 
leisure (along with an increase in overall income) compared to the original equilibrium at A. Thus, there will be a corresponding decrease in work time (i.e., the supply of labour will decrease). In Figure 3.2, we assume that the wage rate remains the same after the introduction of the welfare system.

\section{Figure 3.2.}

The Effect of an Increase in Nonlabour Income on Labour Supply

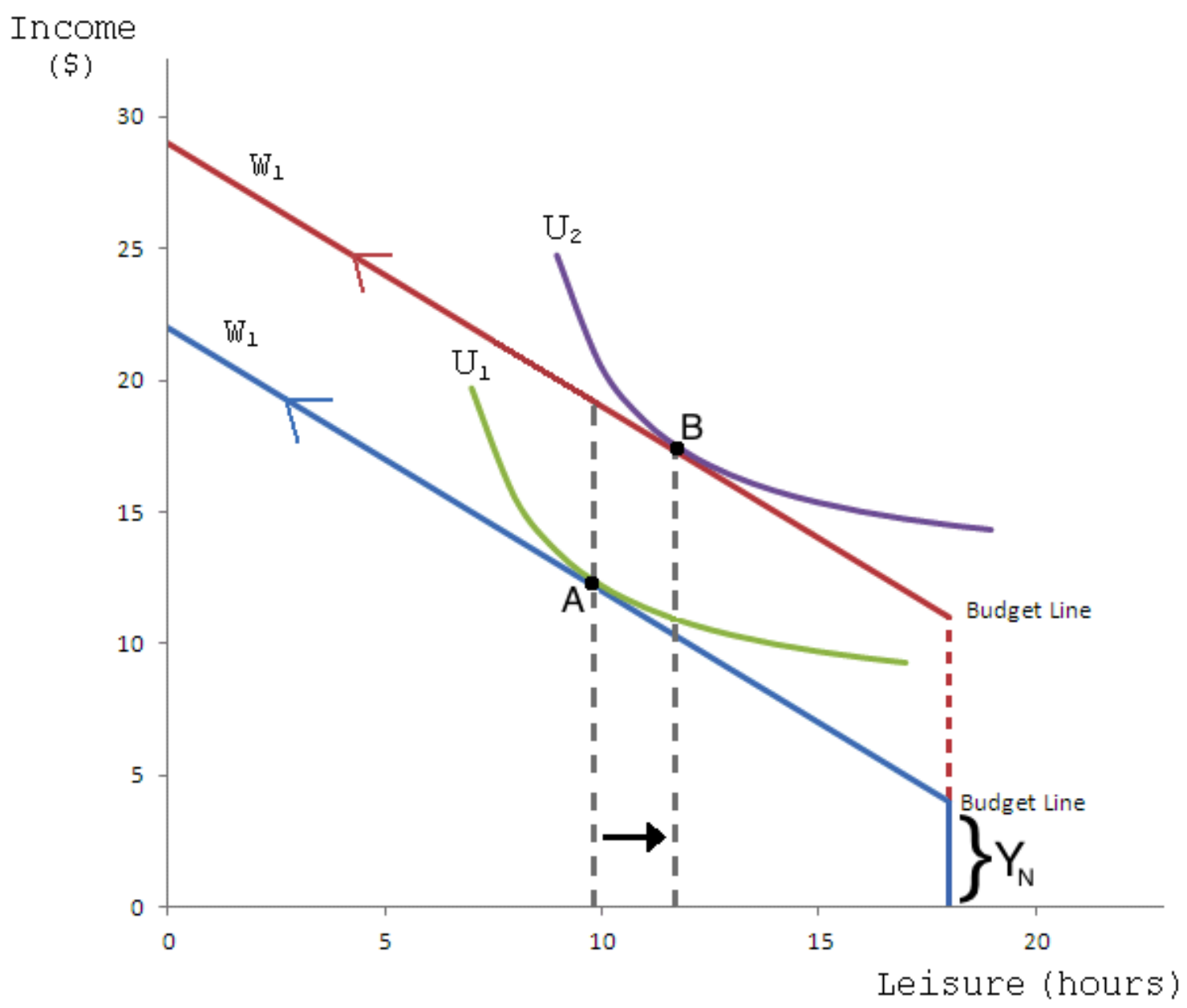

In the case of an increase in SA benefit levels (as in the case of any lump sum increase in non-labour income) money is essentially dropping from the sky. This represents a "pure income effect." Indeed, an increase in SA benefit levels will "never 
cause a nonparticipant to enter the labour force and may cause some participants to withdraw from the labour force" (Benjamin et al., 2007, p. 52).

In Figure 3.2, the increase in SA benefit levels (i.e., the guarantee level) has a clear and direct effect on labour supply: it leads to less of it. With that established, let us now turn to a consideration of another key dynamic involved with SA: the tax-back rate on income earned by SA recipients. A change in the tax-back rate is, in effect, a change in the person's (net) wage rate, and is represented by and change in the slope of the budget constraint.

\section{Figure 3.3. Substitution and Income Effects of a Wage Increase}

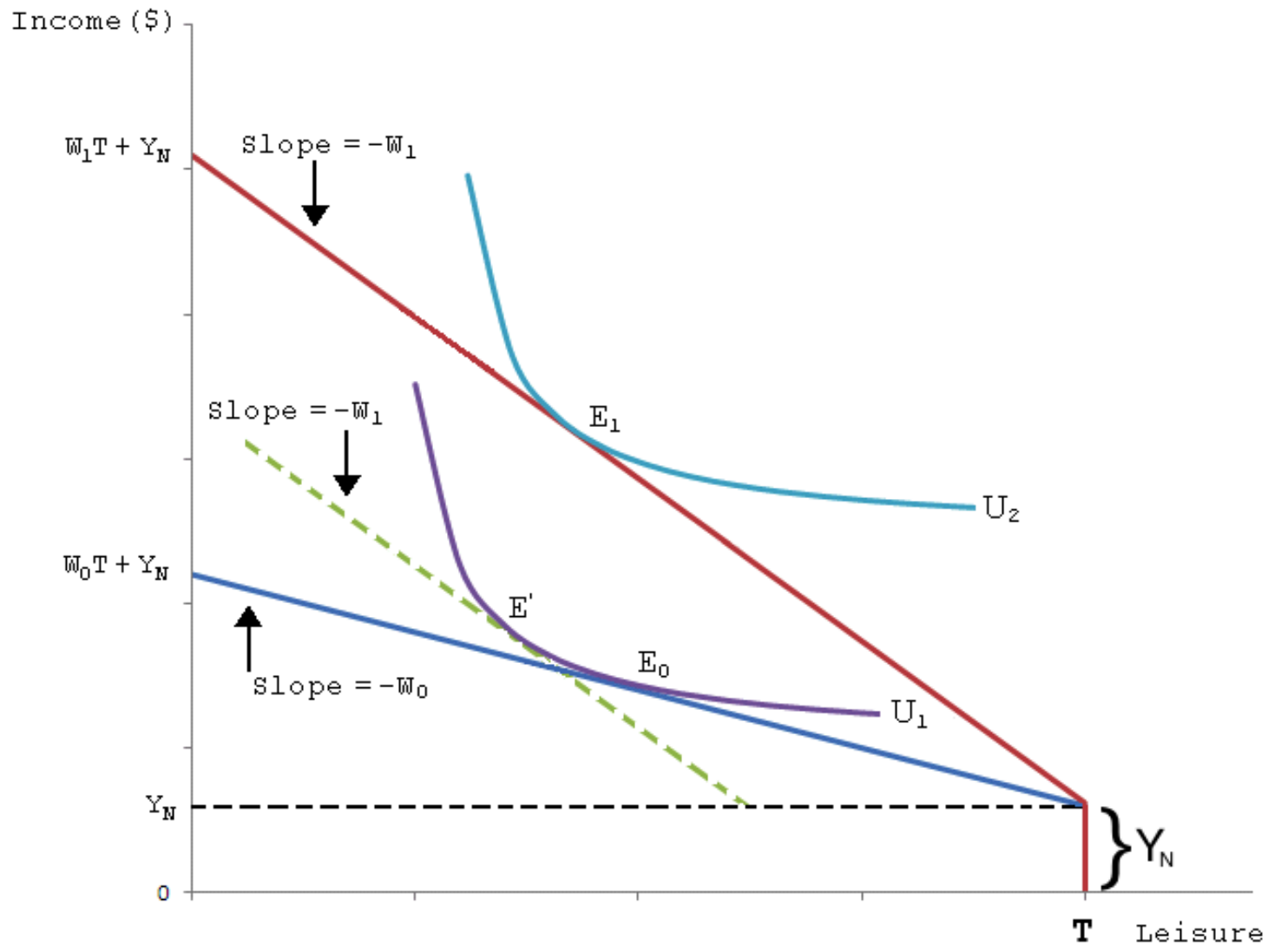


Figure 3.3 depicts what happens in the event of an increase in the individual's net wage rate, holding constant the benefit $\left(Y_{N}\right)$ received when no work is done. (In the case of an individual receiving last-resort SA, this could be caused, among other things, by a decrease in the marginal tax-back rate. ${ }^{41}$ ) There are two effects of such a change in wage rate (graphically, a move from $W_{0}$ to $W_{l}$ ). First, because more income can now be gained from each additional hour of work, the individual may want to work additional hours, holding utility constant. This is known as the substitution effect. (In economics, a substitution effect generally refers to the dynamic whereby a price change leads to a substitution between goods, holding utility constant.) The price of leisure has risen and so, holding the person on the original indifference curve, $\left(U_{1}\right)$, he or she will want to consume less of it. This effect follows from the assumption of convex indifference curves (i.e. their shape), which in turn derives from the assumption of diminishing marginal utility from the consumption of either good (income or leisure). As you pivot the budget constraint along the same curve by increasing the price of leisure (increasing the wage rate) the tangency point changes and leads to a point with less leisure and more consumption. Graphically, this is represented by a move from $E_{0}$ to $E$ '. Something else occurs as well however: for any given level of hours worked, the individual has more income than previously — they can use this to consume more of everything, including leisure. This is known as the income effect. (In economics, the income effect refers to the change in goods purchased as a direct result of the change in overall purchasing power caused by a price change.) If we continue to assume that leisure is a normal good (as we did in discussing Figure 3.2), then the income effect would lead to more leisure

${ }^{41}$ It could also be caused by an increase in the statutory minimum wage rate. 
consumed (which means less work). Graphically, this is represented by a move from $E$ ' to $E_{1}$.

Thus, in the case of a wage increase in this model — namely, a model that includes a welfare system with a positive tax back rate- - the substitution and income effects run counter to one another. The total effect on labour supply is therefore theoretically ambiguous and warrants empirical investigation. The new equilibrium point, $E_{l}$, in Figure 3.3 could therefore lie either to the left or the right of $E_{0}$. Indeed, in the end, we want to know the overall (or net) effect. Graphically, the strength of both effects can be seen in the above type of visual. If the new equilibrium point $\left(E_{l}\right)$ lies to the left of $E_{0}$, then the net effect is a decrease in leisure and an increase in labour supply. If it were to lay to the right (not shown), then the net effect is an increase in leisure (and decrease in labour supply).

The model presented above underlies most economic studies of welfare caseloads. It also underlies the analysis that will be presented forthwith and it will be referenced throughout the present essay. While the model explains labour supply, the regression in the current essay aims to model welfare caseloads. Since increased use of welfare programs implies reduced labour supply, I am considering the reduced form relationship between welfare benefits and welfare caseloads (mediated by changes in labour supply which do not explicitly appear in the model). 


\subsection{Theoretical Econometric Model}

The theoretical econometric framework for the present essay is Moffitt's "static labor supply model" (Moffitt, 2003, p. 314) and is based on the simple theoretical model outlined in the last section. In Moffitt's model, the formula for the SA benefit is represented abstractly by:

$$
B=G-t(W H+N)
$$

where $B$ is total benefits and $G$ is the "guarantee level" (Moffitt, 2003, p. 314) provided by an SA program. Essentially, the total benefit consists of a fixed amount which is then reduced as income from other sources, including earnings, rises. $W$ represents the hourly wage rate and $H$ represents (paid) hours worked so that $W H$ is labour market earnings. $N$ represents non-wage income. Benefits are reduced by the fraction $t$ of every additional dollar of labour market earnings or non-wage income. Thus, $t$ represents the marginal tax back rate discussed above. It should be noted that, in measuring $G$ (the statutory benefit guarantee), Moffit's simple model does not capture all forms of SA benefits, which can include special diet allowances, transportation benefits, drug and dental benefits, and clothing allowances.

Based loosely ${ }^{42}$ on the framework proposed by Blank (2002), I use a panel approach to an econometric analysis of caseloads using time series data for six Canadian provinces. According to Blank (2002), a "typical regression equation based on state panel data" can be represented as follows:

\footnotetext{
${ }^{42}$ I say "loosely" because, though this framework guided me in the initial phase of the study, I ended up using a slightly more complicated model that will be discussed below in the section titled "Evaluating the Determinants of Social-Assistance Rates for Singles."
} 


$$
Y_{s t}=\alpha_{s}+\beta_{t}+\delta P_{s t}+\gamma X_{s t}+\varepsilon_{s t}
$$

In the above equation, $Y_{s t}$ is the caseload variable. For the United States context, that refers to AFDC/TANF caseloads in state $s$ in year $t$. In Canada, it will refer to SA caseloads in a given province in a given year. $\alpha_{s}$ represents the set of "estimated state fixed effects for all $s$ states." $\beta_{t}$ represents a set of "year fixed effects for all $t$ years," meaning that it refers to the effect of a nationwide policy change such as a change to the benefit level of the Earned Income Tax Credit (in the US) or the Canada Assistance Plan in Canada.

$P_{s t}$ is a set of policy-specific parameters that take on a value of either 1 or 0 , depending on whether or not a policy is in place. $\delta$ is its associated vector of coefficients, which represents the impact of the existence of said policy $\left(P_{s t}\right)$ on total caseloads $\left(Y_{s t}\right)$, all else being equal (i.e. its marginal effect on caseload changes). $X_{s t}$ is a set of "all other" variables considered important, such as SA benefit levels in each province or the unemployment rates of a given state in a given year. $\gamma$ is its associated vector of coefficients, which represents the impact of a one unit change in said variable $\left(X_{s t}\right)$ on total caseloads $\left(Y_{s t}\right)$, all else being equal. This regression analysis will estimate the unknown parameters.

The above equation "is usually estimated with a weighted least squares estimation procedure, with weights based on state population" (Blank, 2002, pp. 1124-25). This means that the estimate of each coefficient incorporates the weight of that state's population. As I will explain later, I chose a slightly different method based on the approach taken by Kneebone and White (2009). 


\subsubsection{Potential Drawbacks of Pooling Cross-Sectional Data}

Following Blank (2002) and Kneebone and White (2009), pooling has been used in the present analysis, meaning that time series data for multiple provinces have been stacked "one on top of the other" (Shalev, 2007, p. 279). Pooled regression has been popular among a large body of researchers since the early 1990s (Shalev, 2007, p. 262), as it has the advantage of increasing the number of observations when only a small number of jurisdictions is being studied over a relatively short period of time. However, there is a serious drawback to pooling as well: in light of the fact that each Canadian province has different, province-specific independent variables, there is a strong likelihood that pooling the panels will "muddy the causal waters still further" (Shalev, 2007, pp. 279-280). Indeed, the coefficients (i.e., marginal effects) on the major independent variables will likely be different across provinces (and not the same, as my model assumes). In such cases, it is important to recognize "that there may be striking causal discontinuities across different" jurisdictions (Shalev, 2007, p. 288). Put differently, it is important "not to treat pooled data simply as more data..." (Shalev, 2007, p. 281).

Pooling is helpful, however, in explaining dynamic (i.e., time series) processes. For example, if independent variables take on different values across different provinces, it is entirely possible that they are a result of "long-run (structural) differences." Insofar as this can be ascertained, the aforementioned drawbacks of pooling can be interpreted accordingly (Shalev, 2007, pp. 281-282). Hence the importance of well-rounded analysis that is not limited to a simple regression. Or, in Shalev's words, "the credibility of statistical conclusions needs to be checked against the cases" (Shalev, 2007, p. 282). 
Thus, in the present essay, time series and cross-sectional data are pooled, effectively assuming that the causal relationship between some important independent variables (e.g., the unemployment rate) and the dependent variable is the same across provinces. In fact, the coefficients are probably different both across provinces and across time, and my regression will effectively be ignoring this. In light of this serious limitation, findings should be interpreted with caution. 


\subsubsection{Previous Canadian Efforts at Estimating Determinants of Caseloads}

A substantial amount of research has been done on determinants of welfare caseloads in the United States, with a particular eye towards assessing the impact of the 1996 Personal Responsibility and Work Opportunity Reconciliation Act (PRWORA). For well over a decade after the passage of that legislation, welfare caseloads were generally on a downward trend, prompting researchers to ask: what factors were most responsible for this reduction in caseloads? Thus, researchers-most using variations of the theoretical and empirical models sketched in the previous sections-have devoted considerable effort to trying to understand the extent to which the PRWORA, statespecific policies and macroeconomic factors, respectively, have affected caseloads (Snarr, 2013). But this research has not dealt with singles without dependents- in part because, as previously noted, singles without dependents are not eligible to receive lastresort social assistance in most American states. Though fewer studies have been done looking at the situation across Canadian provinces, four such studies are worth discussing as a backdrop to the present analysis. Like the American research, all four of the Canadian studies treat welfare caseloads, adjusted for provincial population, as the dependent variable. For the independent variables, the Canadian studies typically use a combination of macroeconomic variables, provincial welfare policies and SA benefit levels.

Kneebone and White's 2009 analysis of the determinants of welfare caseloads in all Canadian provinces is the basis of the methodological approach of the present analysis. Using administrative data, the authors construct their dependent variable (the "social assistance rate") by dividing the number of SA cases (across all household types) 
by the population aged 17-64 in province $i$ in year $t$. Key to the analysis-and in view of the aforementioned concerns raised by Shalev (2007) - is the use of dummy independent variables to represent packages of administrative changes to SA programs in British Columbia, Alberta and Ontario; this is done for specific time periods, in order to reflect the introduction of significant changes to administrative rules that were aimed at reducing caseloads and that are quite unlike those in the other seven provinces.

Kneebone and White (2009) find that the lagged SA rate, the unemployment rate and SA benefit levels all have a significant impact on caseloads. And for BC, Alberta and Ontario, they find that administrative procedures have a much stronger role in explaining caseload changes than do other independent variables. Their dataset was limited to 14 years of data; and because the dataset did not disaggregate by household type, they were forced to undertake an aggregated consideration of all household groups together. In their conclusion, they note: "While our suspicion is that those classified as 'single employable' were the most strongly affected by the changes in administrative procedures, this remains a question for further research" (Kneebone \& White, 2009, pp. 36-37).

A conference paper written four years earlier by Arnau, Crémieux, and Fortin (2005) undertakes a similar analysis, also using annual panel data. Like Kneebone and White (2009) the dependent variable in the analysis is the percentage of each province's population on SA. Unlike Kneebone and White (2009), the authors do not account for welfare reform in BC, Alberta and Ontario; nor do they include a lagged value for the SA rate. But like Kneebone and White (2009), the authors do not assess the differential impact of variables on specific household types. Their analysis finds that rules governing 
receipt of unemployment insurance benefits have a strong impact on welfare caseloads (after holding other variables constant). ${ }^{43}$ The authors conclude that the positive impact of minimum wage rates on the SA rate is stronger than its negative impact; this is to say, a higher minimum wage leads to a higher SA rate. The authors also find that the unemployment rate and SA benefit levels have important impacts on welfare caseloads. For their dependent variable, Berg and Gabel (2010) also use the fraction of the population on welfare (excluding the elderly). Following Kneebone and White's (2009) example, the authors use dummy variables for British Columbia, Alberta and Ontario. Unlike Kneebone and White (2009) their analysis does not include a lagged SA rate as one of the independent variables. One key finding is that the unemployment rate has more than twice as much influence on caseloads than the "new reform strategies" in BC, Alberta and Ontario — namely, "[w]ork requirements, diversion, earnings exemptions, and time limits..."44 However, these strategies are still found to be more important than SA benefit levels. Further, they find the impact of minimum wage rates on SA caseloads to be statistically insignificant.

In a more recently analysis (2013) Berg and Gabel use survey data from the Survey of Labour and Income Dynamics (SLID) for welfare receipt (while

\footnotetext{
${ }^{43}$ Kneebone and White (2009) do not assess the impact of these rules on SA caseloads. After having "experimented with a variable measuring the generosity of EI benefits" that had no effect on the SA rate, they decided against using it in their three final specifications (Kneebone \& White, 2009, p. 38). Likewise, for all three of my specifications, I experimented with a variable representing the percentage of workingage adults receiving EI, finding no significance at $5 \%$ or better.

${ }^{44}$ By contrast, Kneebone and White found the impact of the unemployment rate to be much smaller than the "new reform strategies" in question.
} 
acknowledging that SLID vastly under-estimates welfare receipt). ${ }^{45}$ With individuallevel data, they use welfare receipt as a dependent variable taking on the value of 0 or 1 for each individual. Once again, the authors use dummy variables to represent "new reform strategies" in $\mathrm{BC}$, Alberta and Ontario. However, their use of microdata in this analysis allows for analysis by both household type and age group. Consistent with their 2010 analysis, they find that "new reform strategies" do have a statistically significant and negative impact on caseloads. The authors conclude that the "new reform strategies" had an especially significant effect on four subgroups: immigrants, Aboriginal people, single parents and disabled persons. Benefit levels are found to have a rather modest impact on SA participation. The authors call for more research looking at determinants of welfare participation for subpopulations.

The present analysis adopts an approach similar to that of Kneebone and White (2009), using the same types of macroeconomic variables as well as independent dummy variables to represent rule changes in $\mathrm{BC}$, Alberta and Ontario. However, the present study distinguishes itself from Kneebone and White's analysis in two important ways. First, it will focus on singles - that is, single adults without dependents. Second, to construct the dependent variable, it will rely on administrative caseload data obtained directly from provincial SA officials, an approach that avoids the problem of underreporting of SA receipt.

\footnotetext{
${ }^{45}$ The authors note that several studies make the case that SLID relies on self-reported survey data and that respondents appear to under-report SA receipt. For example, one study (Warburton \& Warburton, 2004) finds that SLID figures for SA benefits received are just 65 percent of those reportedly paid out according to administrative data.
} 


\subsection{Data and Descriptive Statistics}

This section provides an overview of the data used in the present analysis, including an explanation of where the data was obtained. The first part of this section discusses caseload data, which was challenging to obtain. Readers should note that it is the caseload data that sets the present analysis apart from much of the previous research: it is both disaggregated by family type and based on administrative data (which is more accurate than survey data). The second part of this section discusses the independent variables which, by comparison, were rather easy to obtain. The provinces covered in the present analysis are British Columbia, Saskatchewan, Ontario, Quebec, New Brunswick and Newfoundland and Labrador. The time period covered is 1989 to $2010 .^{46}$

\subsubsection{Dependent Variable: Caseloads}

The dependent variable in this analysis is the social assistance rate for singles $\left(S A_{i, t}\right)$ - the number of single SA cases for the month of March (in province $i$ and year $t$ ) divided by the single population aged 17-64 (in province $i$ and year $t$ ). To be consistent with previous research by Kneebone and White (2009), I multiply this rate by $100 .{ }^{47}$ For this essay, I initially sought an annual figure representing last-resort SA caseloads for singles (also known as 'single employables') for every Canadian province and territory (1989-2010 inclusive). This proved challenging because there is no one repository for such data. Appendix 3.1 of the present essay provides a detailed discussion of the sources of the caseload data. In brief, I used two major sources for caseload data: 1) the

\footnotetext{
${ }^{46}$ More complete information on all data sources can be found in Appendix 3.1.

${ }^{47}$ From this point on, when I refer to my use of the "social assistance rate," I am in fact referring to the rate multiplied by 100 .
} 
Inventory of Income Security Programs in Canada, formerly a publication of Health and Welfare Canada; and 2) administrative data sent directly to me by provincial officials. In the case of Québec, I also visited the office of the National Council of Welfare during the summer of 2011 to obtain hard copies of spreadsheets; also in the case of Québec, I obtained data for some years from the Rapport statistique sur les prestataires, an annual publication of the Québec government. Regrettably, I was unsuccessful in obtaining caseload data for the years under consideration for four provinces and all three territories. In the case of Prince Edward Island, Nova Scotia, Manitoba and all three territories, the data were not available; in the case of Alberta, the data was available, but only at a charge of approximately $\$ 500$.

Table 3.1 provides singles caseload figures for the six provinces under consideration, for the years 1989 and 2010, respectively. Table 3.2 provides figures for all years under analysis. These tables suggest that, for the $1989-2010$ period, singles caseloads (in absolute terms) more than doubled in Ontario, and nearly doubled in Newfoundland and Labrador. By contrast, singles caseloads in British Columbia were almost cut in half during this period. Three initial observations can therefore be made at this juncture about caseload patterns for the 1989-2010 period. First, there was significant variance across provinces in terms of year-over-year changes in singles caseloads. The provinces did not move together as a group; rather, each went its separate way. Second, and without any consideration of either the potential adverse effects of lower caseloads or factors that led to the changes, Ontario and Newfoundland and Labrador emerge from this period looking like underperformers - that is, as provinces, they have the misfortune of having their SA caseloads grow (which is generally seen as 
being unpopular politically and indicative of economic underperformance). Third, from the standpoint of provincial officials wanting to see caseloads decrease, British Columbia appears to be the clear winner-that is, the one province under consideration that managed to overcome the critical policy challenge of large numbers of single adults on last-resort social assistance.

Table 3.1

Singles Caseloads, 1989 and 2010 - Totals and Rates

\begin{tabular}{|c|c|c|c|c|c|c|}
\hline \multirow{3}{*}{ Province } & \multicolumn{3}{|c|}{ Caseloads } & \multicolumn{3}{|c|}{ Social Assistance Rate } \\
\hline & \multicolumn{2}{|c|}{ Year } & \multirow{2}{*}{$\begin{array}{l}\text { Percentage } \\
\text { Change }\end{array}$} & \multicolumn{2}{|c|}{ Year } & \multirow{2}{*}{$\begin{array}{c}\text { Percentage } \\
\text { Change }\end{array}$} \\
\hline & 1989 & 2010 & & 1989 & 2010 & \\
\hline NL & 8,996 & 15,810 & $75.7 \%$ & $8.5 \%$ & $15.7 \%$ & $84.7 \%$ \\
\hline NB & 26,275 & 18,079 & $-31.2 \%$ & $20.4 \%$ & $12.4 \%$ & $-39.2 \%$ \\
\hline QC & 215,536 & 258,498 & $19.9 \%$ & $16.5 \%$ & $14.7 \%$ & $-10.9 \%$ \\
\hline ON & 83,490 & 148,594 & $78.0 \%$ & $4.5 \%$ & $5.5 \%$ & $22.2 \%$ \\
\hline SK & 14,917 & 19,057 & $27.8 \%$ & $9.4 \%$ & $8.9 \%$ & $-5.3 \%$ \\
\hline $\mathrm{BC}$ & 65,961 & 43,254 & $-34.4 \%$ & $11.9 \%$ & $4.5 \%$ & $-62.2 \%$ \\
\hline
\end{tabular}

Note. Source varies, depending on province and year. See Appendix 3.1 for details.

\subsubsection{Explaining the Difficulty in Obtaining Caseload Data}

To better understand why caseload data for singles were difficult to obtain, I undertook six key informant interviews. ${ }^{48}$ Each interviewee is knowledgeable on the topic of gathering SA caseload data, but their specific roles will not be discussed in this essay in order to preserve confidentiality. Key informants helped me understand how caseload data was once gathered and why this changed.

\footnotetext{
${ }^{48}$ Ethics approval was obtained from the Carleton University Research Ethics Board.
} 


\subsubsection{CAP}

During the CAP years (see Essay 1), the federal government had a strong incentive to track SA data from the provinces and territories. In the words of one key informant:

The feds were paying 50 cents on the dollar and therefore wanted to know what the situation was like on the ground. If the provinces said 'you owe us $\$ 1$ billion,' the feds wanted proof as to what it was being spent on (I1).

There was therefore a group of federal public servants whose formal responsibilities included the collection of welfare statistics. The group's official name was the Social Program Information and Analysis Division and was part of the Social Policy Branch of the Welfare Systems Information Branch of Health and Welfare Canada. This was, in effect, the CAP's provincial statistical unit. The group, whose major focus was SA, became quite efficient (I3). In the words of one key informant: "When provinces [would] send data there [were] often errors that only a team of experienced researchers would catch" (I4).

Beginning in 1981, the group established common parameters for provinces to follow (I3):

The jurisdictions were all different. It was very, very difficult to get agreement across jurisdictions on what to release, what to keep, what to track, how to interpret it. Each province felt it was their own responsibility (I6).

There were additional challenges particular to certain provinces. In the case of Prince Edward Island:

There were lengthy delays from them. Often there was just one contact person. If that person had moved on, you were out of luck. PEI also changed their data management system at one time. That made it challenging...[But with most jurisdictions, i]f we persisted, we eventually got [the data]. But there were delays (I6). 
Provinces were notified that, under the General Assistance provision of CAP, staff from Health and Welfare Canada were responsible for collecting the welfare data. But, even after provinces released the data to the federal officials, provincial officials still had to vet information in the reports before publication. Each report was known as the Inventory of Income Security Programs in Canada. Each such Inventory report provided an overview of all income security programs across Canada —roughly 100 of the 200 pages were devoted solely to SA. The reports provided information on eligibility (including asset and earnings exemptions), special benefits and caseload statistics. The production of these annual Inventory reports began in 1981. The first hard copy was released in 1984 and the last edition in 1993. Seven were produced in total— roughly one every 18 to 24 months, which was the approximate length of the 'production cycle' (in light of the aforementioned vetting process) (I3).

CAP annual reports were also produced (as per CAP's reporting requirements), but with less detailed welfare statistics. For example, CAP's annual reports did not disaggregate by household type (I3). In short, the research team described above, in producing their Inventory publication, “took things way beyond CAP's reporting requirements" (I6).

\subsubsection{Post-CAP}

Shortly before CAP's termination, Health and Welfare Canada had been "split down the middle." Welfare was transferred to what became Human Resources Development Canada (HRDC, now ESDC) and "the welfare folks were not well received" (I4). HRDC did not want to continue doing the Inventory, but it could have (I4). In short, the end of the Inventory coincided with the end of CAP, but CAP's demise 
in and of itself was not the direct cause. The end of CAP formally excused the provinces from the requirement to provide SA information to any central body, but provinces remained willing to provide it when requested (I3). For example, when the National Council of Welfare sought to publish welfare caseload data (such as in their 1998 Profiles of Welfare report), they had "no difficulty getting the data" once they contacted each province and territory directly (I2)

Beginning in 2010, the federal government began producing a new report that included caseload data. It was known as the Social Assistance Statistical Report. This was generated via the Federal-Provincial-Territorial Income Support Working Group, which consisted of Directors of Income Support from the provinces and territories, as well as representation from the federal government. Members of the working group recognized that collecting this data was critical—indeed, provincial, territorial and federal officials deemed the new report a useful tool for planning and policy development (I6). ${ }^{49}$ Methodology was consistent across provinces and across time. However, its most recent iteration only included caseload data from 1995 to 2008 inclusive. There are currently no plans in place to extend its caseload data beyond 2008 [I3]; and, as of September 2014, the report is not readily accessible online.

\footnotetext{
${ }^{49}$ That said, each province's Minister did have to 'sign off' on the release of provincial data (I6).
} 
Table 3.2

Singles Caseloads, Six Provinces (1989-2010)

\begin{tabular}{ccccccc}
\hline \multirow{2}{*}{ Year } & \multicolumn{7}{c}{ Province } \\
\cline { 2 - 7 } & BC & SK & ON & QC & NB & NL \\
\hline 1989 & 65,961 & 14,917 & 83,490 & 215,536 & 26,275 & 8,996 \\
1990 & 60,572 & 14,500 & 95,287 & 222,785 & 26,609 & 9,934 \\
1991 & 74,047 & 14,699 & 159,213 & 238,127 & 29,714 & 10,853 \\
1992 & 89,658 & 17,071 & 221,096 & 269,372 & 33,468 & 11,852 \\
1993 & 104,530 & 19,945 & 239,858 & 287,041 & 34,181 & 14,061 \\
1994 & 112,692 & 21,957 & 244,226 & 304,710 & 32,205 & 15,855 \\
1995 & 117,764 & 21,969 & 221,106 & 307,123 & 29,187 & 17,137 \\
1996 & 108,140 & 21,634 & 170,838 & 307,751 & 28,608 & 17,565 \\
1997 & 94,357 & 21,063 & 158,283 & 299,511 & 29,781 & 17,433 \\
1998 & 85,615 & 19,919 & 141,039 & 287,155 & 28,266 & 15,325 \\
1999 & 76,457 & 20,528 & 118,553 & 276,163 & 26,292 & 14,801 \\
2000 & 70,393 & 20,713 & 105,113 & 268,771 & 23,877 & 15,380 \\
2001 & 66,169 & 20,217 & 87,801 & 259,735 & 22,532 & 14,721 \\
2002 & 61,274 & 19,137 & 96,120 & 259,334 & 21,893 & 14,756 \\
2003 & 42,466 & 18,480 & 97,061 & 258,651 & 21,400 & 15,309 \\
2004 & 35,403 & 18,782 & 101,072 & 257,858 & 20,472 & 15,457 \\
2005 & 29,349 & 18,218 & 104,752 & 256,239 & 19,995 & 15,907 \\
2006 & 25,688 & 18,247 & 110,002 & 254,888 & 19,552 & 15,603 \\
2007 & 25,944 & 18,338 & 110,501 & 256,105 & 18,634 & 15,397 \\
2008 & 27,482 & 17,161 & 108,638 & 252,478 & 17,827 & 15,258 \\
2009 & 35,641 & 17,302 & 127,442 & 254,381 & 17,190 & 15,148 \\
2010 & 43,254 & 19,057 & 148,594 & 258,498 & 18,079 & 15,810 \\
\hline
\end{tabular}

Note. Sources vary. See Appendix 3.2 for details. For simplicity, each province is denoted by its Canada Post abbreviation. 


\subsubsection{Independent Variables}

Independent variables used in the analysis consider the impact of three main types of influences on SA caseloads: the SA regulatory context (both federal and provincial); labour market conditions; and SA benefit levels.

The official unemployment rate for working-age males in each province is represented by $U R_{i, t}$ for the province and year in question. As per Kneebone and White (2009), the rate is for males aged 25-54. This is considered a useful proxy for the strength of the economy. Using the rate for prime age males, as opposed to the overall unemployment rate, may avoid endogeneity problems. ${ }^{50}$ Indeed, including males under the age of 25 could make the variable sensitive to other independent variables, such as the post-secondary participation rate (which increased sharply during the period under consideration). Moreover, including females could make the SA rate sensitive to factors such as: variation across both time and province in the availability of child care; variation across both time and province in provincial child benefits; and variation across time in the availability of federal child benefits. I expect a higher unemployment rate for males in this age group to result in higher SA caseloads for singles.

Like Kneebone and White (2009), I have decided against using an independent variable representing a lagged value for the unemployment rate, while acknowledging that the unemployment rate may at times influence the SA rate with a lag. For example, Stapleton's analysis of the relationship between Ontario's official unemployment rate and the percentage of Ontario's population on social assistance (from 1981 until 2010)

\footnotetext{
${ }^{50}$ An omitted variable (such as the rate of post-secondary participation) might affect both the SA rate and unemployment rate if the rate was not restricted to prime age males.
} 
suggests that there is a lag, but that it varies considerably over time. Indeed, during the recession of the early 1990s, there was virtually no lag between the two variables. Yet, during the mild recession of the early 2000s, there was a more discernable lag (Stapleton, 2012). Aside from the unemployment rate, I have no other reason to believe that there is a lagged effect involved with any of my model's independent variables.

The natural logarithm of annual, second-quintile income for unattached individuals in the province and year in question is denoted by $\log (W P I)_{i t}$ where WPI stands for 'working poor income.' Figures represent market income, in 2010 constant dollars. First quintile income is very low and includes all SA recipients; by contrast, second quintile income is viewed here as being the 'next level up' the income ladder (i.e., the real alternative to receiving SA). I expect higher 'working poor' income-as represented by average income in the second quintile-to reduce caseloads. The more remunerative a 'working poor' job, the more SA recipients find gainful employment attractive, and the less attractive they find SA.

The natural logarithm of last-resort SA benefit levels is represented by $\log (\operatorname{Ben})_{i, t}$. Specifically, it is the natural logarithm of the annual figure for the province and year in question, measured in 2010 constant dollars. I expect higher last-resort SA benefit levels to result in higher last-resort SA caseloads. As per Moffit (2003), the higher the SA benefit levels, the easier it is to live on SA benefits, the less incentive a recipient has to find paid employment and the higher the expected number of SA beneficiaries.

A one-year lagged value of the social assistance rate for singles (for the province and year in question) is represented by $S A \operatorname{lag}_{i, t}$. The SA rate itself represents single SA cases in month of March (in province $\mathrm{i}$ and year $\mathrm{t}$ ) divided by the single population aged 
17-64 (in province $i$ and year $t$ ). The figure for the month of March is being used, as opposed to the annual average, because it is common for provincial welfare officials to make the March figure available to the public. As per Kneebone and White (2009), for each province, I expect that the higher the value of the SA rate in the previous year, the higher the current year's SA rate.

The variables ON1996 and BC1996 are dummy variables meant to reflect particularly strict eligibility criteria (including the introduction of work-for-welfare provisions) introduced in Ontario and British Columbia respectively in 1996. Use of such variables is recommended by Kneebone and White (2009), who argue that these variables should assume the value of zero for all years except 1996-2003 in both Ontario and British Columbia (Kneebone and White, 2009). For the present analysis, I assume that, for the 2003-2010 period, administrative rules remained relatively strict and that the dummy should remain 'on.’ Analysis by Klassen and Buchanan (2006), Wallace, Klein, \& Reitsma-Street (2006), Klein and Pulkingham (2008), Lankin and Sheikh (2011) and Klein (2012) lends support to this claim. Thus, in the present essay, a dummy of 1 indicates the existence of stricter administrative rule changes (put in place to discourage SA dependency), while a dummy of 0 indicates a lack of very strict criteria. Like Kneebone and White (2009), I expect the existence of such strict rules to lead to lower caseloads. When eligibility criteria are made more strict, more recipients become ineligible, making caseloads lower.

Some caution is in order when using such dummies, however. For example, administrative changes that took place with Ontario's SA system during the 1989-2010 period include repeated changes to the way in which employment income has been 
treated for the purpose of calculating SA benefit levels, ${ }^{51}$ as well as the 1993 introduction of case file investigations (Klassen \& Buchanan, 2006). At least in the case of Ontario, there is therefore a risk in suggesting that administrative changes made in 1996 were the defining moment in the 1989-2010 period.

Following Kneebone and White (2009), I estimate provincial fixed effects $\left(\beta_{i}\right)$ and year fixed effects $\left(\gamma_{t}\right)$. By including the provincial fixed effects, I acknowledge that each province has its own characteristics (in ways that are constant over time) that likely influence the dependent variable in ways not easily measured and not captured by the values of the other independent variables. ${ }^{52}$ By including the year fixed effects, I acknowledge that events not easily measured may have transpired in certain years that influenced the dependent variable irrespective of the values of the other independent variables (and that do not vary a great deal across provinces). ${ }^{53}$

My estimating equation is given by:

$S A_{i, t}=\alpha_{0+} \beta_{i}+\gamma_{t}+\alpha_{1} U R_{i, t}+\alpha_{2} \log (W P I)_{i, t}+\alpha_{3} \log (B e n)_{i, t}+\alpha_{4} O N 1996+\alpha_{5} B C 1996+\alpha_{6} S A$ $\operatorname{lag}_{i, t}+\varepsilon_{i, t}$

\footnotetext{
${ }^{51}$ A 1989 change increased the number of eligible households; a 1992 change had the opposite effect; and a change in 2000 decreased eligibility further (Klassen \& Buchanan, 2006).

${ }^{52}$ For example, a greater degree of cultural acceptance of SA in a province that has consistently experienced relatively high levels of unemployment (e.g. Newfoundland and Labrador) could increase the likelihood of singles in that province seeking SA (rather than seeking employment).

${ }^{53}$ For example, a television series with very high viewership that negatively depicts the lives of SA recipients could create increased stigma of SA receipt for a one- or two-year period (and therefore decrease the likelihood of singles applying for-or remaining on-SA during that time).
} 
Table 3.3

Independent Variables

\begin{tabular}{|c|c|}
\hline Symbol & Interpretation \\
\hline$\beta_{i}$ & Provincial fixed effects \\
\hline$\gamma_{t}$ & Year fixed effects \\
\hline$U R_{i, t}$ & $\begin{array}{l}\text { Unemployment rate for males (aged 25-54) for } \\
\text { province and year in question }\end{array}$ \\
\hline $\log (W P I)_{i, t}$ & $\begin{array}{l}\text { Natural logarithm of second quintile income for } \\
\text { province and year in question }\end{array}$ \\
\hline $\log (B e n)_{i, t}$ & $\begin{array}{l}\text { Natural logarithm of yearly social assistance } \\
\text { benefit levels for province and year in question }\end{array}$ \\
\hline SA $\operatorname{lag}_{i, t}$ & $\begin{array}{l}\text { One-year lagged value of social assistance } \\
\text { rate for province and year in question }\end{array}$ \\
\hline ON1996, BC1996 & $\begin{array}{l}\text { Dummy variables for Ontario and British } \\
\text { Columbia }(1996-2010=1)\end{array}$ \\
\hline
\end{tabular}

Note. Source varies. See Appendix 3.2 for details. 


\subsection{Results}

This section presents results of my regression analysis. It initially presents both summary statistics and an overview of three different regression specifications. This is followed by a consideration of heteroskedascity, which was expected in light of the pooling of data from six different provinces of very different sizes. I discuss how I conducted sensitivity analysis and how I addressed it.

\subsubsection{Summary Statistics}

Table 3.4 provides summary statistics of all variables except for dummies.

Table 3.4

Summary Statistics $(N=132)$

\begin{tabular}{lccccc}
\hline \multicolumn{1}{c}{ Variable } & Min & Mean & Median & Max & $\begin{array}{c}\text { Standard } \\
\text { Deviation }\end{array}$ \\
\hline UR $_{i, t}$ & 3.3 & 9.04 & 8.25 & 18.9 & 3.86 \\
SA lag $_{i, t}$ & 2.89 & 12.95 & 12.89 & 25.75 & 5.61 \\
SA $_{i, t}$ & 2.89 & 12.83 & 12.71 & 25.75 & 5.56 \\
ON1996 & 0 & 0.12 & 0 & 1 & 0.32 \\
$B C 1996$ & 0 & 0.12 & 0 & 1 & 0.32 \\
$\log (\text { WPI })_{i, t}$ & $0^{a}$ & 7.61 & 8.38 & 9.38 & 2.24 \\
$\log (\text { Ben })_{i, t}$ & 7.46 & 8.85 & 8.97 & 9.39 & 0.37 \\
\hline
\end{tabular}

${ }^{a}$ The minimum value of the natural logarithm of second-quintile market income is in fact 0 . This is because, in Newfoundland and Labrador, the actual value of secondquintile market income in some years under consideration was 0 . 


\subsubsection{Initial Regression Results}

Table 3.5 displays the estimated coefficients from the OLS regression analysis. Column 1 presents coefficients when dummies representing year fixed effects, province fixed effects and stricter administrative procedures (in the case of Ontario and British Columbia) are excluded from the model. Column 2 excludes only dummies representing stricter administrative procedures (in Ontario and British Columbia). Column 3 presents coefficients when all independent variables (including all dummies) are included in the regression. For all three specifications, the most significant variable is the lagged value for the SA rate. The significance of both the unemployment rate for 'working age' males and SA benefit levels is lost when dummies are included for provincial fixed effects and year fixed effects. Further, when all dummies are included, the one independent variable with significance at the 5 percent level or better - in addition to the previous year's SA rate - is BC's administrative procedures. For all three specifications, the income levels of the 'working poor' (i.e. second quintile income) are never found to be significant. Finally, Ontario's stricter administrative procedures (beginning in 1996) are not significant. 
Table 3.5

Regression Coefficients for the SA Rate, 1989-2010, $N=132$

(Standard Error in Brackets)

\begin{tabular}{lccc}
\hline Parameter & $(1)$ & $(2)$ & $(3)$ \\
\hline UR & 0.18 & 0.14 & 0.15 \\
& $(0.04)^{\star * *}$ & $(0.09)^{*}$ & $(0.08)^{*}$ \\
log(Ben) & 0.69 & 0.39 & 0.4 \\
& $(0.3)^{* *}$ & $(0.3)$ & $(0.3)$ \\
log(WPI) & 0.07 & -0.06 & -0.06 \\
& $(0.07)$ & $(0.06)$ & $(0.06)$ \\
SA lag & 0.93 & 0.9 & 0.87 \\
& $(0.02)^{* * *}$ & $(0.03)^{* * *}$ & $(0.03)^{* * *}$ \\
ON1996 & & & -0.59 \\
& & & $(0.4)$ \\
BC1996 & & & -1.01 \\
& & & $(0.4)^{* *}$ \\
Adj $R^{2}$ & 0.97 & 0.98 & 0.98 \\
\hline
\end{tabular}

Note. Asterisks denote coefficients that are statistically different than zero at the $1 \%\left(^{* * *}\right), 5 \%\left({ }^{* *}\right)$ and $10 \%\left(^{*}\right)$ levels or better.

Table does not include provincial or year fixed effects terms.

The adjusted $R^{2}$ values for all three specifications are rather large. Coefficients on all variables are of the expected sign, with one minor exception: 'working poor' income, expected to have a negative coefficient, has a positive sign in the specification that omits all dummies. What is perhaps most remarkable about the results is what is not found to be significant. Focusing on the specification that includes all of the dummies, I shall now discuss the result for each independent variable one by one.

The high level of significance for the lagged SA rate is both intuitive and consistent with Kneebone and White's 2009 findings for all household types. It does not 
come as a major surprise that the proportion of a province's working-age adults receiving last-resort SA in one year will be rather similar to the next. And this likely explains the presence of very high adjusted $R^{2}$ values.

As alluded to above, regression results that include all dummies indicate that the unemployment rate for prime working-age males is significant only at the 10 percent level, unlike the Kneebone and White's result.

The natural logarithm of last-resort SA benefit levels does not attain significance at the 5 percent level when all dummies are included in the model. Kneebone and White (2009) did find 5 per cent significance for this variable in their regression. This would suggest that singles without dependents may not respond as much to changes in SA benefit levels as do other household types, a phenomenon that deservers further qualitative exploration.

Consistent with Kneebone and White's 2009 findings, the present analysis finds that the variable used as a proxy for 'working poor' income does not attain 5 per cent significance. This suggests that, like other household types receiving last-resort SA, singles without dependents do not appear to react significantly to changes in income for 'the next level up' in the labour market.

As predicted, and consistent with Kneebone and White (2009), British Columbia's stricter administrative procedures beginning in 1996 meet the 5 per cent significance level for singles without dependents. That is, they appear to have been effective in reducing SA caseloads for all household groups, including singles. However, in contrast to Kneebone and White's analysis, the coefficient on the dummy variable capturing stricter administrative procedures in Ontario beginning the same year does not 
meet the 5 per cent significance level. For some readers, this might suggest that Ontario's singles were not affected by Ontario's new procedures to the extent that singles were affected in British Columbia or to the extent that all household types were affected in both provinces. However, as was discussed above and will again be discussed in the conclusion, this may also speak to the problems inherent with the use of dummy variables to represent complex changes to administrative rules for many years.

In contrast to Berg and Gabel (2010, 2013), my results do not find an association between administrative rules in Ontario and caseloads in that province. But like Berg and Gabel $(2010 ; 2013)$ my results do find a negative association between administrative changes in British Columbia and caseloads in that province. Unlike Arnau, Crémieux and Fortin (2005) and Berg and Gabel (2013) my results do not suggest that SA benefit levels are positively associated with caseloads. And unlike Berg and Gabel (2010) my results do not find the official unemployment rate to have a strong influence on caseloads. That said—and as previously noted—none of these previous studies look specifically at singles. It should not come as a surprise that different household groups respond differently to the many independent variables under consideration. 


\subsubsection{Heteroskedasticity}

In light of the fact that this regression involved the pooling data from provinces with very different sizes, I expected heteroskedasticity. Both a Park Test and a Spearman's Rank Correlation Test confirmed heteroskedasticity for the official unemployment rate for prime-age males. ${ }^{54} \mathrm{~A}$ White test (on the entire model) then confirmed heteroskedasticity for the model as a whole. To address the heteroskedasticity, I calculated Huber-White standard errors; Table 3.6 presents the coefficient estimates from Table 3.5 along with the corrected standard errors. As a comparison of Tables 3.5 and 3.6 shows, the correction made no important difference (however, after the correction, the dummy variable representing changes to BC's administrative procedures no longer meets significance at the 5 percent level).

\footnotetext{
${ }^{54}$ The Park Test also indicated heteroskedasticity for the following dummies: 1989, 1991, 2003, 2006 and 2007 (year fixed effects); and Saskatchewan (provincial fixed effects). The Spearman's Rank Correlation Test indicated heteroskedasticity for the following dummies: both the Ontario and BC dummies indicating stricter administrative procedures (for 1996 only); 1990, 1998, 1999, 2001-2010 inclusive (year fixed effects); and BC, Saskatchewan and Quebec (provincial fixed effects). It should be noted that it is common for heteroskedasticity to be detected in dummies.
} 
Table 3.6

Regression Coefficients for the SA Rate

After Correcting for Heteroskedasticity

1989-2010, N=132

(Standard Error in Brackets)

\begin{tabular}{lccc}
\hline & $\mathbf{( 1 )}$ & $\mathbf{( 2 )}$ & $\mathbf{( 3 )}$ \\
\hline UR & 0.18 & 0.14 & 0.15 \\
& $(0.04)^{* * *}$ & $(0.08)^{*}$ & $(0.08)^{*}$ \\
$\log ($ Ben $)$ & 0.69 & 0.39 & 0.4 \\
& $(0.2)^{* * *}$ & $(0.3)$ & $(0.3)$ \\
log(WPI) & 0.07 & -0.06 & -0.06 \\
& $(0.05)$ & $(0.06)$ & $(0.06)$ \\
SA lag & 0.93 & 0.9 & 0.87 \\
& $(0.02)^{* * *}$ & $(0.04)^{* * *}$ & $(0.04)^{* * *}$ \\
ON1996 & & & -0.59 \\
& & & $(0.4)$ \\
BC1996 & & & -1.01 \\
& & & $(0.5)^{*}$ \\
Adj $R^{2}$ & 0.97 & 0.98 & 0.98 \\
\hline
\end{tabular}

Note. Asterisks denote coefficients that are statistically

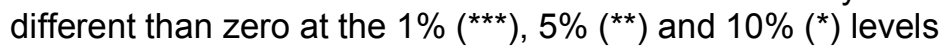
or better. Table does not include provincial or year fixed effects terms. 


\subsection{Conclusion}

This analysis builds on Kneebone and White's 2009 analysis of determinants of social assistance caseloads. But rather than focus on all household groups together, I focus exclusively on singles. Results are categorical in suggesting that the single most important determinant of singles caseloads in a given year is the previous year's caseloads. While that may seem self-evident to some readers, the lack of statistical significance for most other variables is instructive. Indeed, aside from the previous year's caseload level (and after heteroskedasticity has been corrected) no independent variable attains five percent significance or better.

The 'take away' message for some readers will be that benefit levels - as well as changes to the hourly minimum wage (which affects 'working poor' income)-likely have only marginal effects on social assistance caseloads for singles. That said, caution should be exercised in putting too much faith in such a conclusion. Indeed, one drawback of the present analysis is its use of dummy variables representing stricter administrative rules for two provinces. Such a crude methodology cannot capture the idiosyncratic aspects of a province's SA system, as has been illustrated by Klassen and Buchanan (2006) for the case of Ontario. While a strong case can be made that the province's overall administrative structure for SA did become more strict in 1996, a case can also be made that drawing such a categorical line at precisely that moment in time places too much emphasis on changes made in 1996 and insufficient emphasis on administrative changes that took place both before and after 1996.

As noted above, Kneebone and White (2009) suggest that 'single employables' were likely "the most strongly affected by the changes in administrative procedures..." 
(Kneebone \& White, 2009, pp. 36-37). This remains an open question. On the one hand, the present analysis suggests that single employables were indeed affected by BC's stricter administrative procedures; on the other hand, no such relationship is found with respect to Ontario's stricter administrative procedures.

For some policy makers, it may be useful to consider the potential impact of an increase in SA benefit levels for singles on caseloads. Dividing the regression coefficient for the natural logarithm of benefit levels $(0.40)$ by the mean value of the SA rate (12.7) yields a value of 0.03 . This means that even a one percent increase in the real value of benefit levels for singles in a given province (all other things equal and assuming the aforementioned relationship did not occur by chance) would be correlated with just a 0.03 percent increase in the SA rate for singles in that province. In fact, even a five percent increase in the real value of benefit levels for singles in a given province would be associated with just a 0.15 percent increase in the SA rate for singles in that province (meaning that if the SA rate for singles in a given province is 12.7 percent before the five percent increase in benefit levels, the SA rate for singles would remain at 12.7 percent after the rise in benefit levels). 


\subsubsection{Reference List}

Arnau, P., Crémieux, P, \&Fortin, P. (2005). The determinants of social assistance rates: Evidence from a panel of Canadian provinces, 1976-2001. Update of a conference paper presented at the 1998 Annual Meetings of the Canadian Economics Association, Département des sciences économiques, Université du Québec à Montréal, Montreal, Canada.

Battle, K. (2008, April). Presentation to Rethinking Income Support: A Guaranteed Annual Income. Library of Parliament Seminar Series.

Benjamin, D., Gunderson, M., Lemieux, T., \& Riddell, W. C. (2007). Labour market economics: Theory, evidence, and policy in Canada ( $6^{\text {th }}$ ed.). Toronto: McGraw-Hill Ryerson.

Berg, N., \& Gabel, T. (2010). New reform strategies and welfare participation in Canada (MPRA Paper No. 26591). Retrieved from Munich Personal RePEc Archive website: http://mpra.ub.uni-muenchen.de/

Berg, N., \& Gabel, T. (2013). Effects of new welfare reform strategies on welfare participation: Microdata estimates from Canada. Discussion paper, Business School, University of Otago, Dunedin, New Zealand.

Blank, R. M. (2002). Evaluating welfare reform in the United States. Journal of Economic Literature, 40(4), 1105-1166. Retrieved from http://www.aeaweb.org/JEL/

Griffiths, W. E., Hill R. C., \& Judge, G. G. (1993). Learning and practicing econometrics. New York: John Wiley \& Sons, Inc.

Immervoll, H. (2009). Minimum-income benefits in OECD countries: Policy design, effectiveness and challenges (Discussion Paper No. 4627). Retrieved from The Institute for the Study of Labor website:

http://www.iza.org/en/webcontent/index_html

Klassen, T. R., \& Buchanan, D. (2006). Ideology, policy, and economy: Liberal, New Democratic and Conservative reforms of Ontario's welfare program. Journal of Canadian Studies, 40(3), 186-210.

Klein, S. (2012, June 12). New BC welfare rules: some positive steps forward (and a couple steps back) [Web log post]. Retrieved from http://www.policynote.ca/new-bcwelfare-rules-some-positive-steps-forward-and-couple-steps-back/ 
Klein, S., \& Pulkingham, J. (2008). Living on welfare in BC: Experiences of longerterm 'expected to work' recipients. Retrieved from Canadian Centre for Policy Alternatives-BC website:

https://www.policyalternatives.ca/publications/reports/living-welfare-bc

Kneebone, R., \& White, K. (2009). Fiscal retrenchment and social assistance in Canada. Canadian Public Policy, 35(1), 21-40. Retrieved from http://economics.ca/cpp/en/

Lankin, F., \& Sheikh, M. A. (2011). A discussion paper: Issues and ideas. Retrieved from the Commission for the Review of Social Assistance website: http://www.socialassistancereview.ca/

Moffit, R. A. (2003). The temporary assistance for needy families program. In R. A. Moffit (Eds.), Means-tested transfer programs in the United States (pp. 291-363). Chicago: The University of Chicago Press.

Shalev, M. (2007). Limits and alternatives to multiple regression in comparative research. Comparative Social Research, 24, 261-308. doi:10.1016/S01956310(06)24006-7

Snarr, H. W. (2013). Was it the economy or reform that precipitated the steep decline in the US welfare caseload. Applied Economics, 45, 525-540. Doi: 10.1080/00036846.2011.607135

Wallace, B., Klein, S., \& Reitsma-Street, M. (2006). Denied assistance: Closing the front door on welfare in $B C$. Retrieved from Canadian Centre for Policy AlternativesBC website:

http://www.policyalternatives.ca/sites/default/files/uploads/publications/BC_Office_P ubs/bc_2006/denied_assistance.pdf

Warburton, R. N., \& Warburton, W. P. (2004). Canada needs better data for evidencebased policy: Inconsistencies between administrative and survey data on welfare dependence and education. Canadian Public Policy/Analyse de politiques, 30(3). 241-255. Retrieved from http://economics.ca/cpp/en/ 


\section{Appendix 3.1. Detailed Descriptions of Caseload Data Sources}

Caseload statistics are from administrative sources, most of which were requested by the author. Social assistance caseload number for each year usually represents the March (i.e. end-of-fiscal) caseload number for single, employable adults receiving lastresort social assistance in each province.

\section{Newfoundland and Labrador}

These are average caseloads for the month of March, single person cases. Data for 1989 to 1991 inclusive have been obtained from Inventory of Income Security Programs in Canada, formerly a publication of Health and Welfare Canada. The author imputed figures for 1989 and 1991. For 1989, the number of SA cases in March of that year was multiplied by the percentage of March 1990 caseloads that were single persons. For 1991, the total number of SA caseloads in March of that year was multiplied by the average percentage of caseloads that were single persons in March 1990 and March 1992 respectively. Data for 1992 to 2010 were sent to the author by an SA administrator from Newfoundland and Labrador in August 2011. Figures for 1992-2010 represent the average caseload respectively for the month of March. It should be noted that an SA administrator in Newfoundland and Labrador informed the author that he does not have pre-1992 data for single persons-hence the author's use of the aforementioned Inventory of Income Security Programs in Canada publication for pre-1992 data. 


\section{New Brunswick}

These are March figures for singles. The data include benefits provided by both Interim Assistance and the Transitional Assistance Program. The Interim Assistance program was eliminated on 1 January 2010. All figures are administrative data. Administrative data was e-mailed to author from a New Brunswick SA official in November 2011.

\section{Quebec}

This data represents figures for single persons without dependents receiving lastresort social assistance in March. Figures used for 1989-1992 inclusive are from Health and Welfare Canada's Inventory of Income Security Programs in Canada publication. Figures for 1994-1999 inclusive are taken from spreadsheets (hard copies) from the National Council of Welfare and photocopied by the author in August 2011. Figures for 2000-2010 (inclusive) are taken from the Rapport statistique sur les prestataires, compiled annually by the Quebec government and available online. Author imputed 1993 figure by taking average of 1992 and 1994.

\section{Ontario}

This data is for singles without children on Ontario Works. These are March figures. Data from prior to 1998 were adjusted by Ministry staff to reflect the new program. Data was e-mailed to the author in September 2011 by a Ministry staff person. I imputed the figure for 1989 inclusive by multiplying that year's total March caseload 
figure by 0.415 (the percentage of total caseload in 1990 that were single adults without dependents).

\section{Saskatchewan}

These figures represent single persons who received social assistance in March of each year. Prior to 2003, figures are for the Saskatchewan Assistance Program (SAP). From 2003 on, figures are for SAP and Transitional Employment Assistance combinedthe post-2003 client profile of the two programs combined is comparable to the pre-2003 SAP client profile. These figures are all administrative data; they were e-mailed to the author in August 2011.

\section{British Columbia}

These are Single Income Assistance recipients (without dependents) on Temporary Assistance. These are March figures e-mailed to the author in November 2011 by an SA official in British Columbia. Data represent clients who received income assistance provided under one of three Acts: 1. Guaranteed Available Income for Need (pre- 1995); 2. BC Benefits (1996 - March 2002); 3. BC Employment and Assistance (April 2002 to the present). To be counted as a case, a client must have received financial assistance in March. Data exclude clients designated as a Person with Disability. 


\section{Appendix 3.2. Detailed Descriptions of Data Sources for Independent Variables}

\section{Social Assistance Rate $\left(S A_{i, t}\right)$}

Singles caseload in each province, divided by population of singles, aged 17-64 in said province. Data on provincial population of singles aged 17-64 years is from Statistics Canada, CANSIM Table 051-0042. By "singles," I mean "Marital Status Single (not living common law)."

\section{Lagged Social Assistance Rate (SA $\left.\operatorname{lag}_{i, t}\right)$}

Singles caseload in each province, divided by population of singles, aged 17-64 in province in question, with one-year lag. Data on provincial population of singles aged 17-64 years is from Statistics Canada, CANSIM Table 051-0042. By “singles," I mean "Marital Status Single (not living common law)."

\section{Unemployment Rate $\left(U R_{i, t}\right)$}

Unemployment rate, provinces, annual (percent). Unemployment rate, males, 2554. CANSIM Table 282-0002.

\section{Income Second Quintile $\left(W P I_{i, t}\right)$}

These are annual, market figures in 2010 constant dollars. I then took the natural logarithm of these values. Unattached individuals "working poor income." Second quintile only. CANSIM Table 202-0701. Accessed: 30 June 2012. 


\section{Social Assistance Benefit Levels $\left(S A B_{i, t}\right)$}

Annual figure for 'single employables' in constant dollars. I then took the natural

logarithm of these values. Source: National Council of Welfare web site. Accessed: 30

June 2012. 
Appendix 3.3.

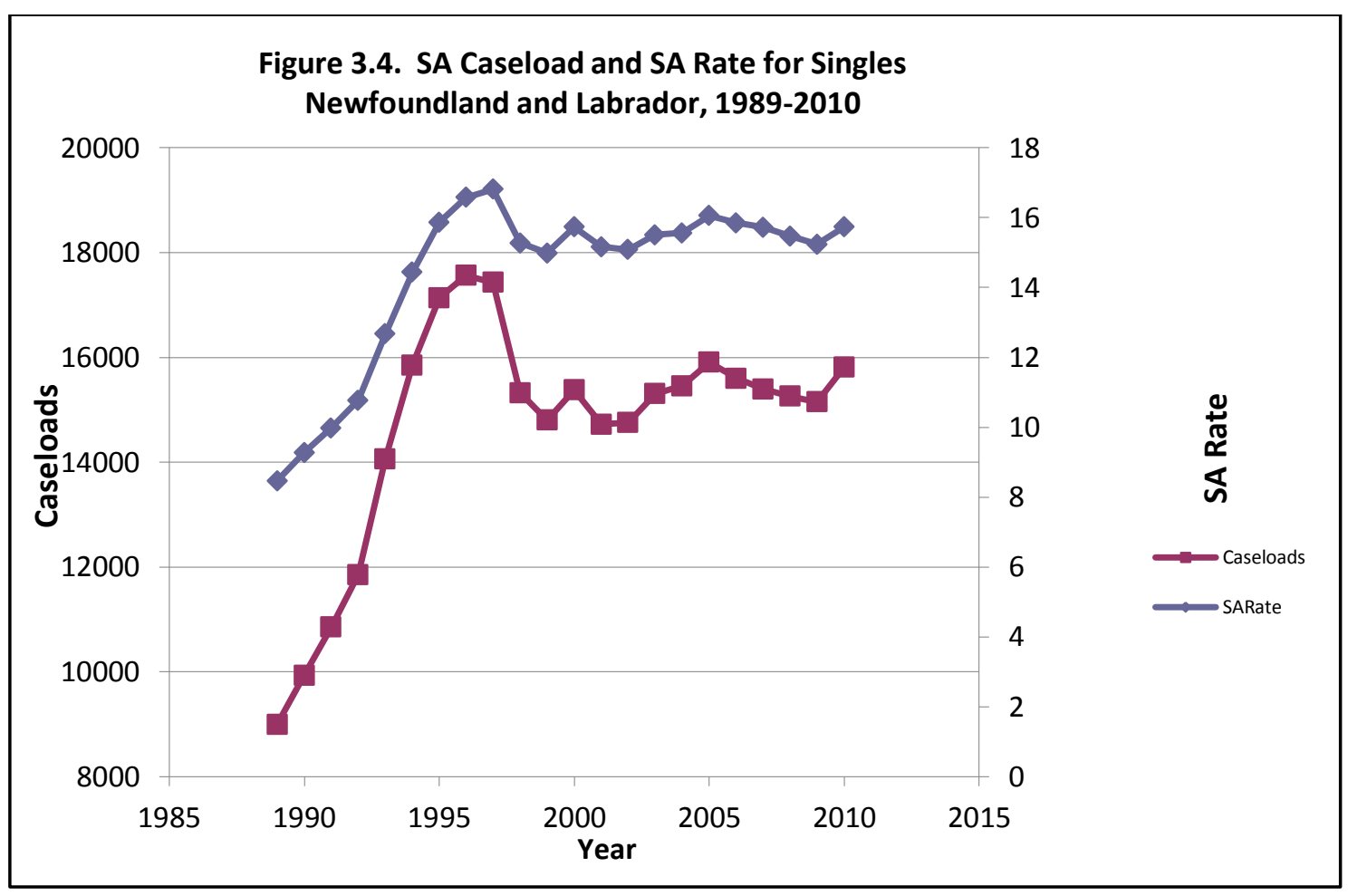


Appendix 3.4.

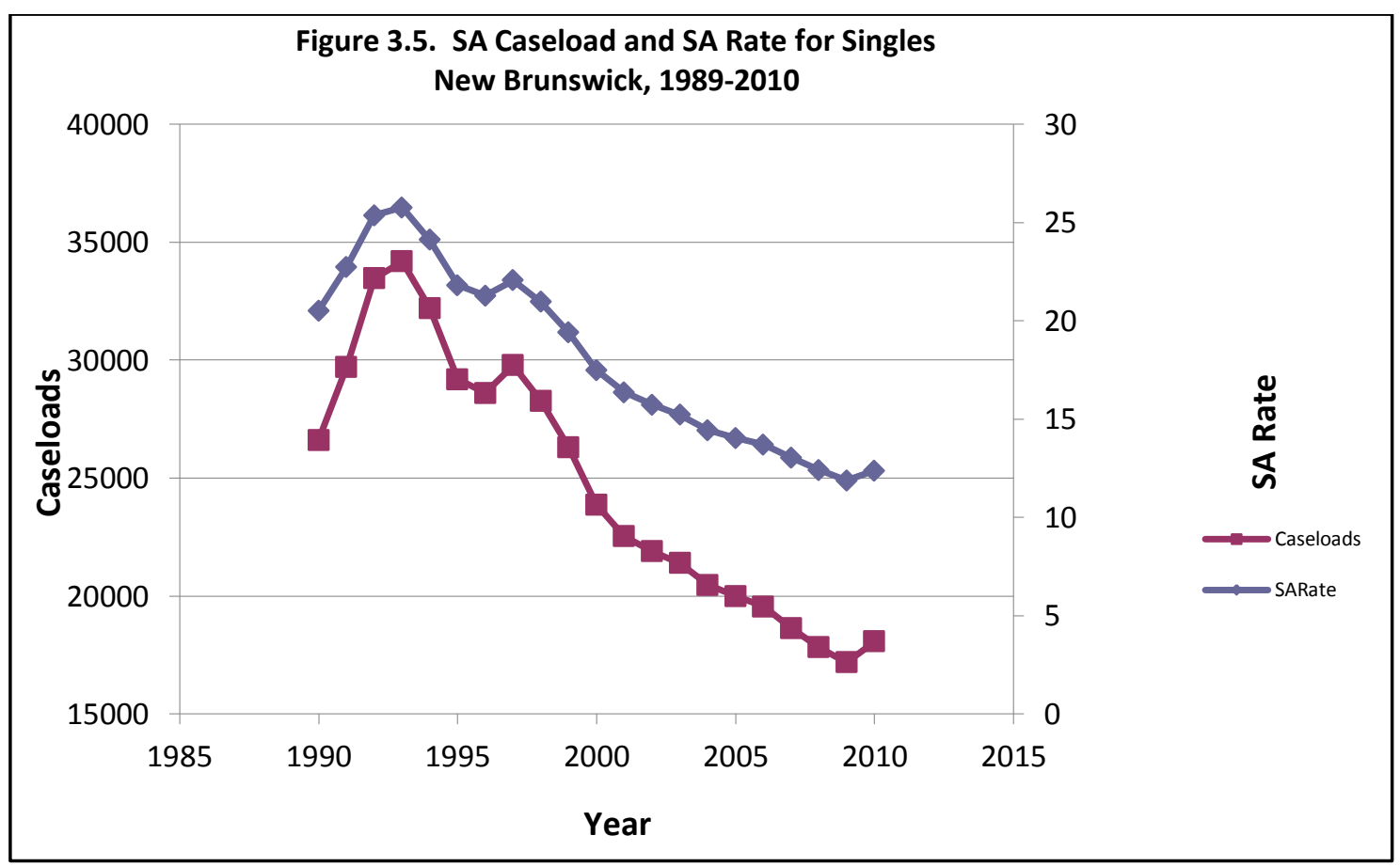


Appendix 3.5.

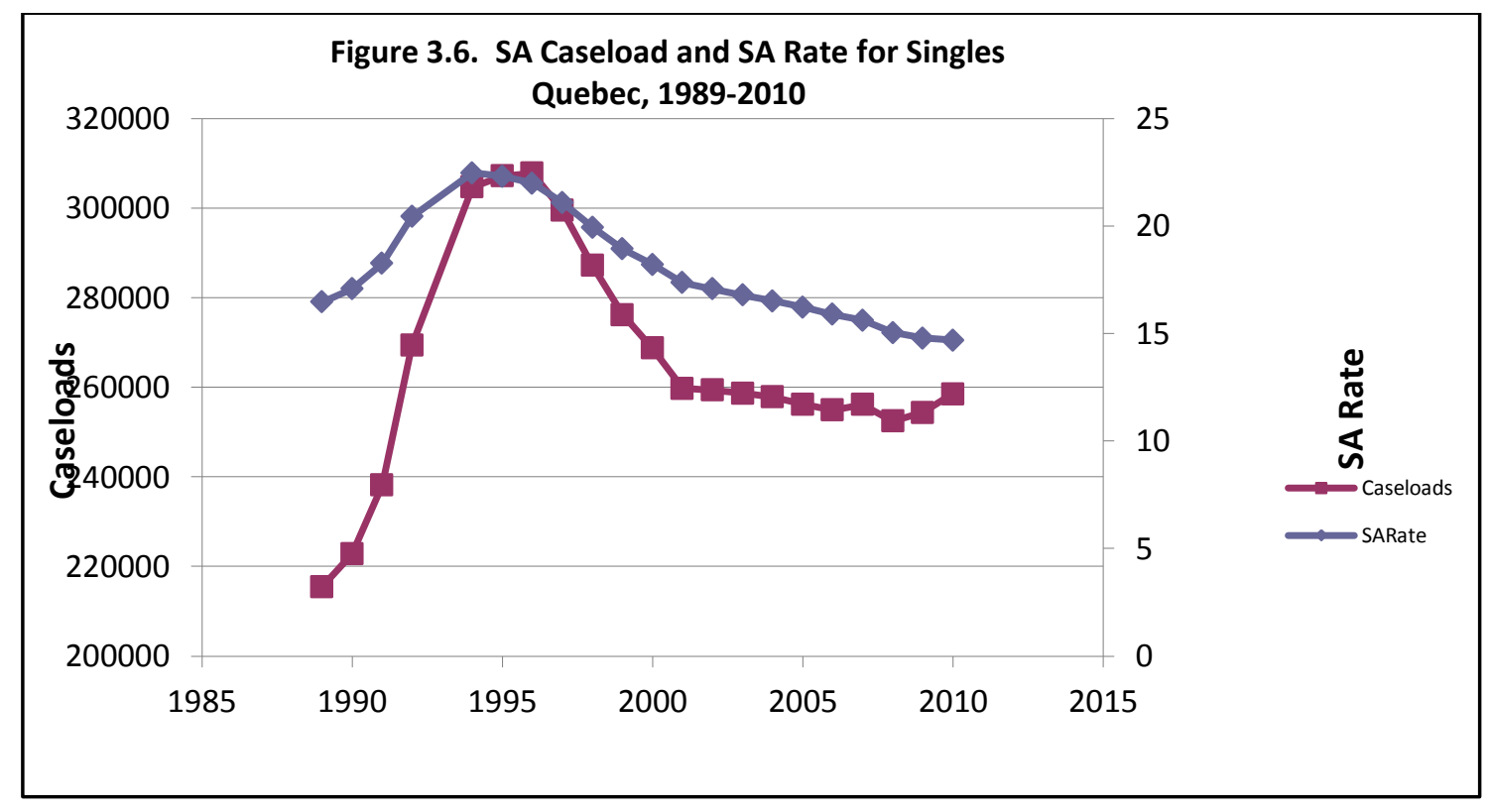


Appendix 3.6.

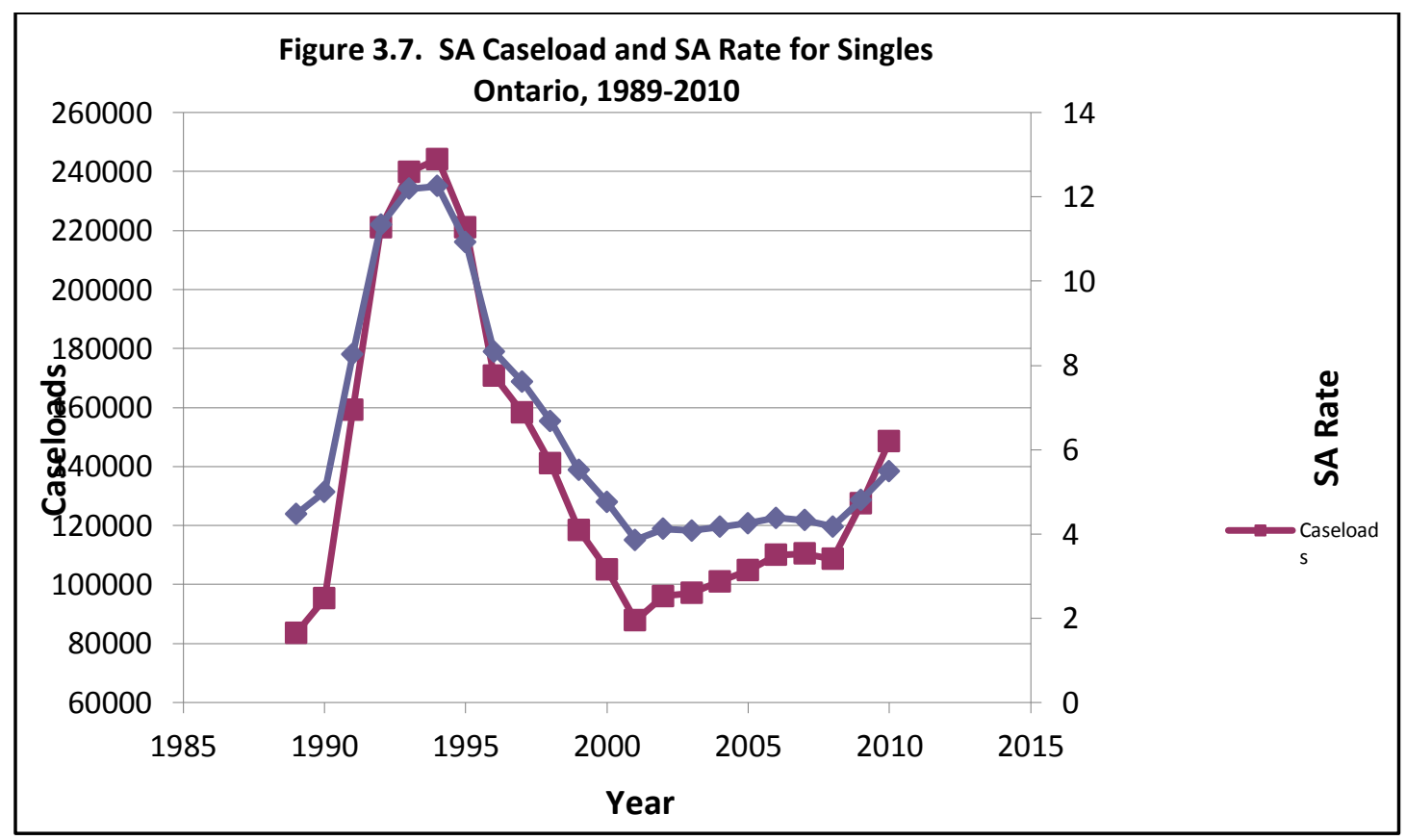


Appendix 3.7.

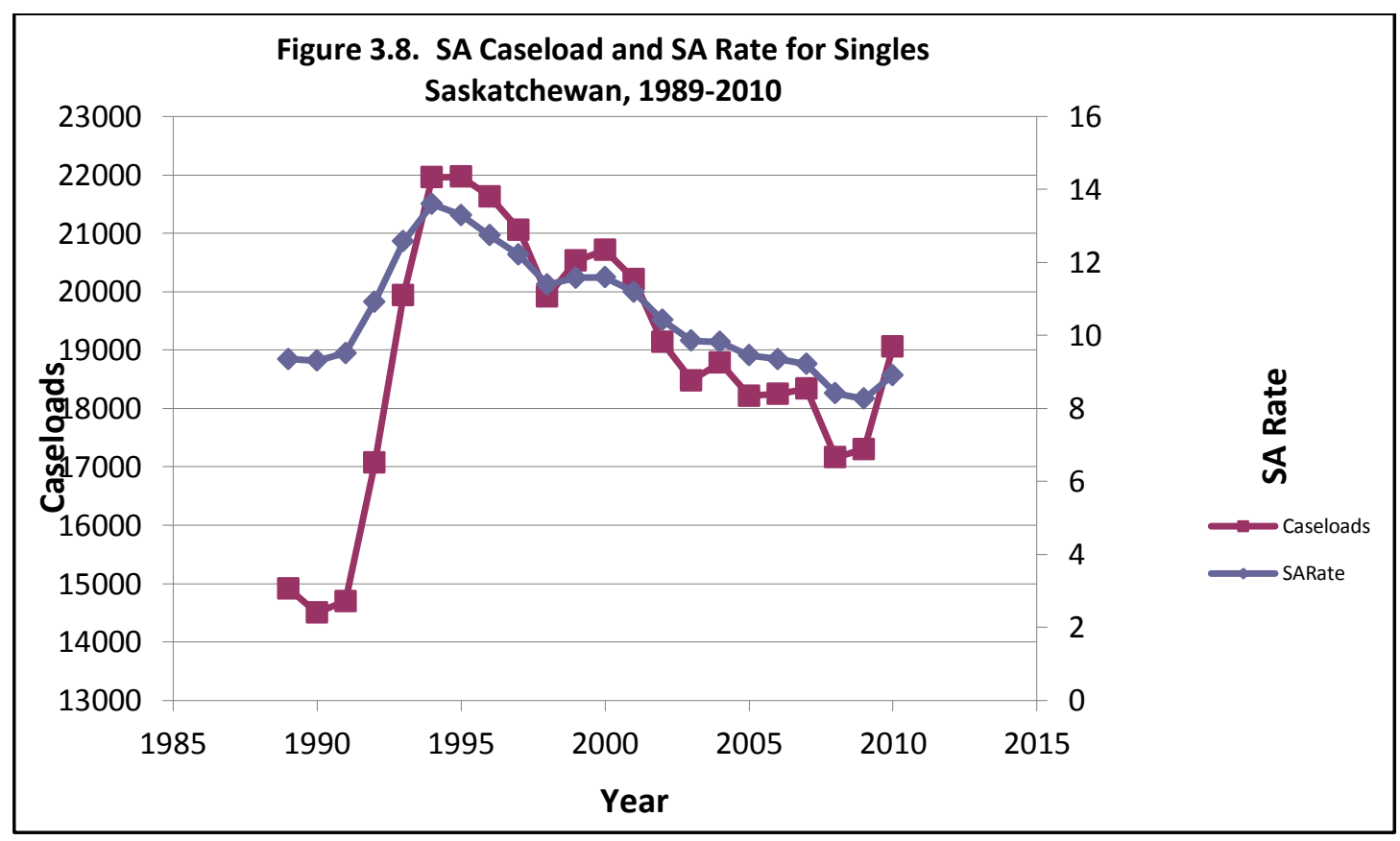


Appendix 3.8.

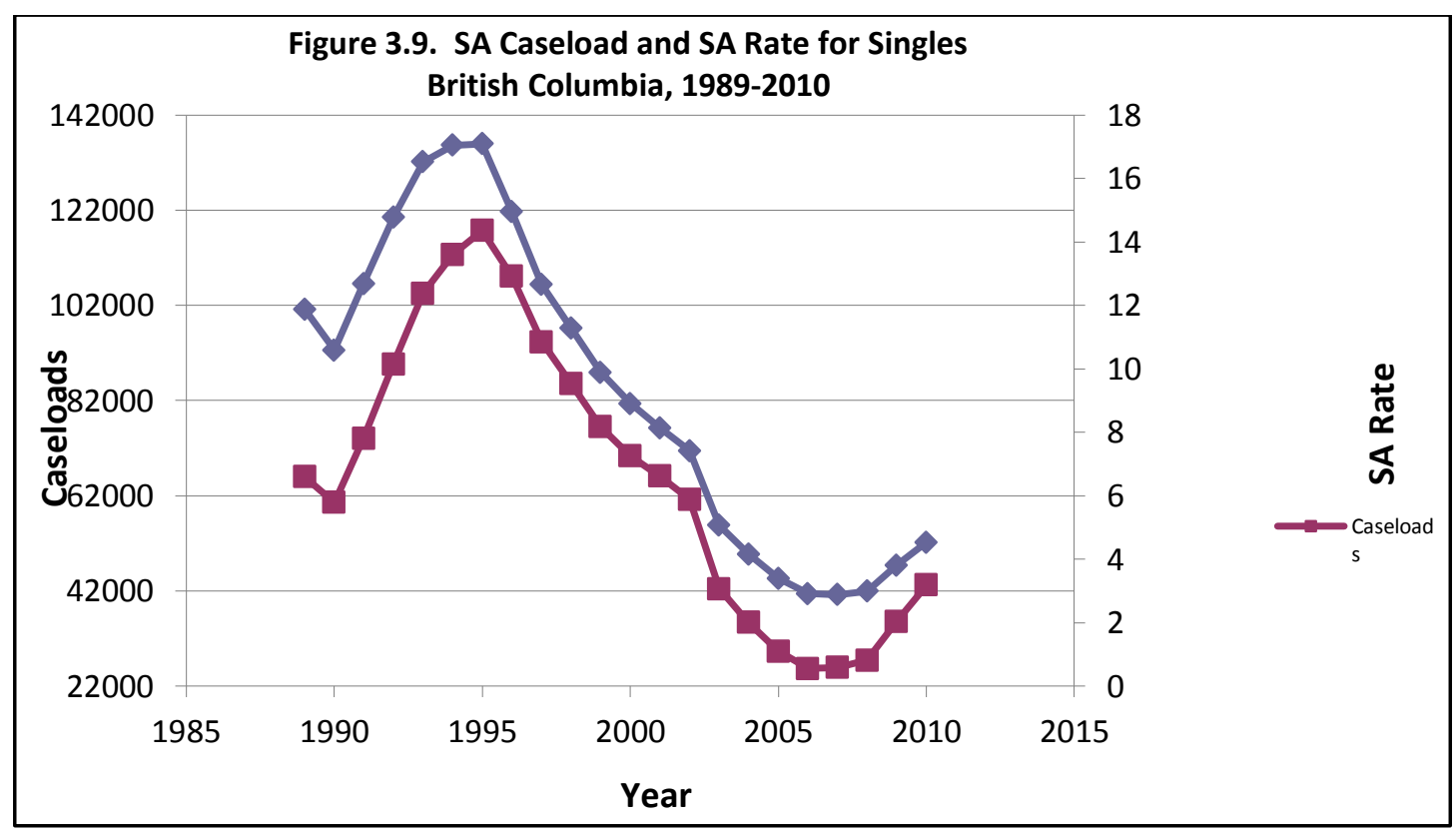


Appendix 3.9.

Table 3.7

Data Matrix

\begin{tabular}{|c|c|c|c|c|c|c|c|c|}
\hline Province & Year & $\begin{array}{l}\text { Male } \\
\text { Unemploymen } \\
\text { t rate, 25-54 }\end{array}$ & ON1996 & BC1996 & $\begin{array}{l}\operatorname{Ln} \\
\text { (WPI) }\end{array}$ & $\begin{array}{l}\text { Ln (Annual } \\
\text { SA Benefits) }\end{array}$ & $\begin{array}{l}\text { Social } \\
\text { Assistance } \\
\text { Rate }\end{array}$ & $\begin{array}{l}\text { Lag of } \\
\text { Social } \\
\text { Assistance } \\
\text { Rate }\end{array}$ \\
\hline $\mathrm{NL}$ & 1989 & 12.7 & 0 & 0 & 8.04 & 8.71 & 8.46 & 8.27 \\
\hline $\mathrm{NL}$ & 1990 & 14.4 & 0 & 0 & 7.17 & 8.73 & 9.28 & 8.46 \\
\hline $\mathrm{NL}$ & 1991 & 15.7 & 0 & 0 & 5.70 & 8.74 & 9.98 & 9.28 \\
\hline $\mathrm{NL}$ & 1992 & 17.9 & 0 & 0 & 6.21 & 8.77 & 10.77 & 9.98 \\
\hline $\mathrm{NL}$ & 1993 & 18.1 & 0 & 0 & 0.00 & 8.75 & 12.67 & 10.77 \\
\hline $\mathrm{NL}$ & 1994 & 18.6 & 0 & 0 & 5.30 & 8.75 & 14.44 & 12.67 \\
\hline $\mathrm{NL}$ & 1995 & 17.5 & 0 & 0 & 0.00 & 8.73 & 15.87 & 14.44 \\
\hline $\mathrm{NL}$ & 1996 & 18.9 & 0 & 0 & 0.00 & 8.20 & 16.58 & 15.87 \\
\hline $\mathrm{NL}$ & 1997 & 18.5 & 0 & 0 & 0.00 & 7.46 & 16.82 & 16.58 \\
\hline $\mathrm{NL}$ & 1998 & 17.5 & 0 & 0 & 0.00 & 7.46 & 15.27 & 16.82 \\
\hline $\mathrm{NL}$ & 1999 & 15.6 & 0 & 0 & 0.00 & 7.46 & 14.98 & 15.27 \\
\hline $\mathrm{NL}$ & 2000 & 15.4 & 0 & 0 & 4.61 & 7.75 & 15.73 & 14.98 \\
\hline $\mathrm{NL}$ & 2001 & 15.8 & 0 & 0 & 5.30 & 8.30 & 15.16 & 15.73 \\
\hline NL & 2002 & 17.1 & 0 & 0 & 0.00 & 9.18 & 15.09 & 15.16 \\
\hline $\mathrm{NL}$ & 2003 & 16 & 0 & 0 & 0.00 & 9.16 & 15.51 & 15.09 \\
\hline $\mathrm{NL}$ & 2004 & 15.6 & 0 & 0 & 0.00 & 9.14 & 15.57 & 15.51 \\
\hline $\mathrm{NL}$ & 2005 & 14.8 & 0 & 0 & 5.99 & 9.13 & 16.06 & 15.57 \\
\hline $\mathrm{NL}$ & 2006 & 15.1 & 0 & 0 & 6.80 & 9.19 & 15.85 & 16.06 \\
\hline $\mathrm{NL}$ & 2007 & 13 & 0 & 0 & 6.40 & 9.22 & 15.72 & 15.85 \\
\hline $\mathrm{NL}$ & 2008 & 12.8 & 0 & 0 & 7.31 & 9.20 & 15.48 & 15.72 \\
\hline $\mathrm{NL}$ & 2009 & 15.4 & 0 & 0 & 7.65 & 9.22 & 15.24 & 15.48 \\
\hline $\mathrm{NL}$ & 2010 & 14.6 & 0 & 0 & 6.80 & 9.20 & 15.73 & 15.24 \\
\hline NB & 1989 & 10.1 & 0 & 0 & 8.04 & 8.44 & 20.36 & 21.14 \\
\hline NB & 1990 & 10.3 & 0 & 0 & 7.97 & 8.45 & 20.51 & 20.36 \\
\hline NB & 1991 & 11.4 & 0 & 0 & 7.70 & 8.47 & 22.73 & 20.51 \\
\hline NB & 1992 & 11.7 & 0 & 0 & 7.44 & 8.44 & 25.36 & 22.73 \\
\hline NB & 1993 & 11.2 & 0 & 0 & 6.40 & 8.43 & 25.75 & 25.36 \\
\hline NB & 1994 & 12.1 & 0 & 0 & 6.68 & 8.43 & 24.12 & 25.75 \\
\hline NB & 1995 & 10.7 & 0 & 0 & 7.74 & 8.41 & 21.81 & 24.12 \\
\hline NB & 1996 & 10.8 & 0 & 0 & 7.24 & 8.41 & 21.27 & 21.81 \\
\hline NB & 1997 & 12 & 0 & 0 & 7.31 & 8.40 & 22.05 & 21.27 \\
\hline NB & 1998 & 11.7 & 0 & 0 & 8.04 & 8.39 & 20.96 & 22.05 \\
\hline NB & 1999 & 9.3 & 0 & 0 & 7.78 & 8.38 & 19.41 & 20.96 \\
\hline
\end{tabular}




\begin{tabular}{|c|c|c|c|c|c|c|c|c|}
\hline NB & 2000 & 9.6 & 0 & 0 & 7.82 & 8.35 & 17.48 & 19.41 \\
\hline NB & 2001 & 10.7 & 0 & 0 & 7.97 & 8.33 & 16.35 & 17.48 \\
\hline NB & 2002 & 10.6 & 0 & 0 & 7.60 & 8.31 & 15.73 & 16.35 \\
\hline NB & 2003 & 10.8 & 0 & 0 & 7.44 & 8.28 & 15.22 & 15.73 \\
\hline NB & 2004 & 10 & 0 & 0 & 7.74 & 8.26 & 14.44 & 15.22 \\
\hline NB & 2005 & 9.9 & 0 & 0 & 8.01 & 8.25 & 14.04 & 14.44 \\
\hline NB & 2006 & 9.1 & 0 & 0 & 8.13 & 8.25 & 13.70 & 14.04 \\
\hline NB & 2007 & 7.8 & 0 & 0 & 8.46 & 8.25 & 13.04 & 13.70 \\
\hline NB & 2008 & 8.7 & 0 & 0 & 8.13 & 8.26 & 12.40 & 13.04 \\
\hline NB & 2009 & 8.5 & 0 & 0 & 8.52 & 8.28 & 11.87 & 12.40 \\
\hline NB & 2010 & 8.7 & 0 & 0 & 8.39 & 8.84 & 12.37 & 11.87 \\
\hline$Q C$ & 1989 & 8.5 & 0 & 0 & 7.90 & 8.66 & 16.46 & 19.97 \\
\hline$Q C$ & 1990 & 9.4 & 0 & 0 & 7.74 & 9.01 & 17.08 & 16.46 \\
\hline$Q C$ & 1991 & 11 & 0 & 0 & 7.50 & 9.07 & 18.26 & 17.08 \\
\hline$Q C$ & 1992 & 12.3 & 0 & 0 & 7.24 & 9.09 & 20.44 & 18.26 \\
\hline$Q C$ & 1993 & 12.7 & 0 & 0 & 7.24 & 9.06 & 21.45 & 20.44 \\
\hline$Q C$ & 1994 & 11.9 & 0 & 0 & 7.55 & 9.07 & 22.47 & 21.45 \\
\hline$Q C$ & 1995 & 10.9 & 0 & 0 & 7.65 & 9.05 & 22.30 & 22.47 \\
\hline$Q C$ & 1996 & 11.3 & 0 & 0 & 7.44 & 9.03 & 21.99 & 22.30 \\
\hline$Q C$ & 1997 & 10.8 & 0 & 0 & 7.00 & 9.00 & 21.09 & 21.99 \\
\hline QC & 1998 & 9.1 & 0 & 0 & 7.38 & 8.99 & 19.94 & 21.09 \\
\hline$Q C$ & 1999 & 8.4 & 0 & 0 & 8.04 & 8.99 & 18.93 & 19.94 \\
\hline$Q C$ & 2000 & 7.7 & 0 & 0 & 8.07 & 8.97 & 18.20 & 18.93 \\
\hline$Q C$ & 2001 & 7.9 & 0 & 0 & 8.32 & 8.97 & 17.35 & 18.20 \\
\hline$Q C$ & 2002 & 8 & 0 & 0 & 8.65 & 8.98 & 17.07 & 17.35 \\
\hline$Q C$ & 2003 & 8.5 & 0 & 0 & 8.72 & 8.97 & 16.78 & 17.07 \\
\hline QC & 2004 & 7.9 & 0 & 0 & 8.82 & 8.97 & 16.52 & 16.78 \\
\hline$Q C$ & 2005 & 7.9 & 0 & 0 & 8.56 & 8.96 & 16.22 & 16.52 \\
\hline$Q C$ & 2006 & 7.4 & 0 & 0 & 8.72 & 8.95 & 15.89 & 16.22 \\
\hline$Q C$ & 2007 & 6.9 & 0 & 0 & 8.67 & 8.94 & 15.62 & 15.89 \\
\hline$Q C$ & 2008 & 7.1 & 0 & 0 & 8.63 & 8.92 & 15.05 & 15.62 \\
\hline$Q C$ & 2009 & 8.5 & 0 & 0 & 8.65 & 8.94 & 14.79 & 15.05 \\
\hline$Q C$ & 2010 & 7.6 & 0 & 0 & 8.58 & 8.93 & 14.69 & 14.79 \\
\hline ON & 1989 & 3.9 & 0 & 0 & 9.32 & 9.23 & 4.46 & 4.22 \\
\hline ON & 1990 & 5.4 & 0 & 0 & 9.10 & 9.33 & 5.00 & 4.46 \\
\hline ON & 1991 & 8.7 & 0 & 0 & 8.68 & 9.37 & 8.27 & 5.00 \\
\hline ON & 1992 & 10.4 & 0 & 0 & 8.79 & 9.39 & 11.33 & 8.27 \\
\hline ON & 1993 & 9.9 & 0 & 0 & 8.48 & 9.39 & 12.19 & 11.33 \\
\hline ON & 1994 & 8.7 & 0 & 0 & 8.37 & 9.39 & 12.25 & 12.19 \\
\hline ON & 1995 & 7.6 & 0 & 0 & 8.59 & 9.32 & 10.93 & 12.25 \\
\hline ON & 1996 & 7.8 & 1 & 0 & 8.52 & 9.13 & 8.33 & 10.93 \\
\hline ON & 1997 & 6.6 & 1 & 0 & 8.37 & 9.11 & 7.61 & 8.33 \\
\hline
\end{tabular}




\begin{tabular}{|c|c|c|c|c|c|c|c|c|}
\hline ON & 1998 & 5.7 & 1 & 0 & 8.61 & 9.10 & 6.68 & 7.61 \\
\hline ON & 1999 & 4.8 & 1 & 0 & 8.70 & 9.08 & 5.51 & 6.68 \\
\hline ON & 2000 & 4.3 & 1 & 0 & 8.79 & 9.06 & 4.76 & 5.51 \\
\hline ON & 2001 & 5.2 & 1 & 0 & 8.87 & 9.03 & 3.86 & 4.76 \\
\hline ON & 2002 & 6 & 1 & 0 & 8.94 & 9.01 & 4.12 & 3.86 \\
\hline ON & 2003 & 5.5 & 1 & 0 & 8.96 & 8.98 & 4.08 & 4.12 \\
\hline ON & 2004 & 5.3 & 1 & 0 & 8.90 & 8.99 & 4.17 & 4.08 \\
\hline ON & 2005 & 5.1 & 1 & 0 & 8.96 & 8.97 & 4.25 & 4.17 \\
\hline ON & 2006 & 4.9 & 1 & 0 & 9.04 & 8.96 & 4.38 & 4.25 \\
\hline ON & 2007 & 5.5 & 1 & 0 & 9.08 & 8.95 & 4.32 & 4.38 \\
\hline ON & 2008 & 5.4 & 1 & 0 & 9.06 & 8.95 & 4.17 & 4.32 \\
\hline ON & 2009 & 8.7 & 1 & 0 & 8.90 & 8.97 & 4.81 & 4.17 \\
\hline ON & 2010 & 7.5 & 1 & 0 & 8.87 & 9.00 & 5.49 & 4.81 \\
\hline SK & 1989 & 6.5 & 0 & 0 & 8.61 & 8.97 & 9.35 & 9.82 \\
\hline SK & 1990 & 6.5 & 0 & 0 & 8.37 & 8.97 & 9.31 & 9.35 \\
\hline SK & 1991 & 6.5 & 0 & 0 & 7.74 & 8.96 & 9.52 & 9.31 \\
\hline SK & 1992 & 7.7 & 0 & 0 & 7.74 & 8.98 & 10.93 & 9.52 \\
\hline SK & 1993 & 8.2 & 0 & 0 & 7.82 & 9.03 & 12.57 & 10.93 \\
\hline SK & 1994 & 5.9 & 0 & 0 & 7.94 & 9.03 & 13.60 & 12.57 \\
\hline SK & 1995 & 6.4 & 0 & 0 & 8.13 & 8.92 & 13.30 & 13.60 \\
\hline SK & 1996 & 6.2 & 0 & 0 & 8.27 & 8.99 & 12.74 & 13.30 \\
\hline SK & 1997 & 5.4 & 0 & 0 & 8.39 & 8.89 & 12.22 & 12.74 \\
\hline SK & 1998 & 5.2 & 0 & 0 & 8.04 & 8.88 & 11.39 & 12.22 \\
\hline SK & 1999 & 5.4 & 0 & 0 & 8.24 & 8.91 & 11.58 & 11.39 \\
\hline SK & 2000 & 4.6 & 0 & 0 & 8.34 & 8.91 & 11.59 & 11.58 \\
\hline SK & 2001 & 4.8 & 0 & 0 & 8.61 & 8.91 & 11.20 & 11.59 \\
\hline SK & 2002 & 5.1 & 0 & 0 & 8.63 & 8.89 & 10.42 & 11.20 \\
\hline SK & 2003 & 5.4 & 0 & 0 & 8.65 & 8.89 & 9.85 & 10.42 \\
\hline SK & 2004 & 4.8 & 0 & 0 & 8.43 & 8.88 & 9.82 & 9.85 \\
\hline SK & 2005 & 4.4 & 0 & 0 & 8.58 & 8.92 & 9.46 & 9.82 \\
\hline SK & 2006 & 4 & 0 & 0 & 8.68 & 9.15 & 9.35 & 9.46 \\
\hline SK & 2007 & 3.4 & 0 & 0 & 8.96 & 9.01 & 9.21 & 9.35 \\
\hline SK & 2008 & 3.3 & 0 & 0 & 8.90 & 9.05 & 8.41 & 9.21 \\
\hline SK & 2009 & 4.4 & 0 & 0 & 9.07 & 9.13 & 8.27 & 8.41 \\
\hline SK & 2010 & 4.7 & 0 & 0 & 8.99 & 9.10 & 8.92 & 8.27 \\
\hline$B C$ & 1989 & 6.9 & 0 & 0 & 9.38 & 9.08 & 11.88 & 14.63 \\
\hline$B C$ & 1990 & 7.4 & 0 & 0 & 9.07 & 9.12 & 10.59 & 11.88 \\
\hline$B C$ & 1991 & 9.2 & 0 & 0 & 8.79 & 9.07 & 12.69 & 10.59 \\
\hline$B C$ & 1992 & 9.2 & 0 & 0 & 8.95 & 9.14 & 14.77 & 12.69 \\
\hline$B C$ & 1993 & 8.7 & 0 & 0 & 8.68 & 9.14 & 16.52 & 14.77 \\
\hline$B C$ & 1994 & 8.5 & 0 & 0 & 8.52 & 9.16 & 17.04 & 16.52 \\
\hline$B C$ & 1995 & 7.7 & 0 & 0 & 8.90 & 9.14 & 17.09 & 17.04 \\
\hline
\end{tabular}




$\begin{array}{lllllllll}\text { BC } & 1996 & 7.8 & 0 & 1 & 8.67 & 9.05 & 14.95 & 17.09 \\ \text { BC } & 1997 & 7.5 & 0 & 1 & 8.63 & 9.04 & 12.65 & 14.95 \\ \text { BC } & 1998 & 8.3 & 0 & 1 & 8.52 & 9.03 & 11.29 & 12.65 \\ \text { BC } & 1999 & 7.8 & 0 & 1 & 8.67 & 9.01 & 9.89 & 11.29 \\ \text { BC } & 2000 & 6.3 & 0 & 1 & 8.84 & 8.99 & 8.90 & 9.89 \\ \text { BC } & 2001 & 7.3 & 0 & 1 & 8.76 & 8.98 & 8.14 & 8.90 \\ \text { BC } & 2002 & 7.9 & 0 & 1 & 8.68 & 8.96 & 7.42 & 8.14 \\ \text { BC } & 2003 & 6.8 & 0 & 1 & 8.78 & 8.92 & 5.07 & 7.42 \\ \text { BC } & 2004 & 5.9 & 0 & 1 & 8.88 & 8.91 & 4.17 & 5.07 \\ \text { BC } & 2005 & 4.9 & 0 & 1 & 9.04 & 8.89 & 3.39 & 4.17 \\ \text { BC } & 2006 & 3.8 & 0 & 1 & 9.08 & 8.87 & 2.91 & 3.39 \\ \text { BC } & 2007 & 3.4 & 0 & 1 & 9.12 & 8.98 & 2.89 & 2.91 \\ \text { BC } & 2008 & 3.8 & 0 & 1 & 9.16 & 9.01 & 3.00 & 2.89 \\ \text { BC } & 2009 & 7.3 & 0 & 1 & 9.21 & 9.01 & 3.81 & 3.00 \\ \text { BC } & 2010 & 7.3 & 0 & 1 & 8.90 & 8.99 & 4.53 & 3.81\end{array}$




\section{Appendix 3.10.}

Table 3.8

Complete Regression Results (With all Dummies Included, After Correcting for Heteroskedasticity) 1989-2010, $N=132$

Variable $\begin{gathered}\text { Coefficient } \\ \text { Estimate }\end{gathered} \begin{gathered}\text { Adjusted } \\ \begin{array}{c}\text { Standard } \\ \text { Error }\end{array}\end{gathered}$ T Statistic $\quad$ P Value $\begin{gathered}\text { Significance } \\ \text { Indicator }\end{gathered}$

\begin{tabular}{|c|c|c|c|c|c|}
\hline Intercept & -3.88 & 2.94 & -1.32 & 0.19 & \\
\hline$U R_{i, t}$ & 0.15 & 0.08 & 1.93 & 0.06 & * \\
\hline $\log (W P I)_{i, t}$ & -0.06 & 0.06 & -0.87 & 0.39 & \\
\hline $\log (B e n)_{i, t}$ & 0.40 & 0.31 & 1.30 & 0.20 & \\
\hline$S A \operatorname{lag}_{i, t}$ & 0.87 & 0.04 & 19.48 & 0.00 & *** \\
\hline ON1996 & -0.59 & 0.44 & -1.33 & 0.19 & \\
\hline BC1996 & -1.01 & 0.52 & -1.94 & 0.06 & * \\
\hline Year1990 & 0.98 & 0.61 & 1.61 & 0.11 & \\
\hline Year1991 & 2.22 & 0.77 & 2.88 & 0.01 & *** \\
\hline Year1992 & 2.66 & 0.81 & 3.29 & 0.00 & *** \\
\hline Year1993 & 2.10 & 0.64 & 3.30 & 0.00 & *** \\
\hline Year1994 & 1.59 & 0.66 & 2.40 & 0.02 & ** \\
\hline Year1995 & 0.87 & 0.71 & 1.22 & 0.23 & \\
\hline Year1996 & 0.60 & 0.72 & 0.83 & 0.41 & \\
\hline Year1997 & 0.92 & 0.70 & 1.32 & 0.19 & \\
\hline Year1998 & 0.36 & 0.63 & 0.58 & 0.56 & \\
\hline Year1999 & 0.66 & 0.63 & 1.04 & 0.30 & \\
\hline Year2000 & 0.93 & 0.67 & 1.38 & 0.17 & \\
\hline Year2001 & 0.57 & 0.57 & 1.01 & 0.32 & \\
\hline Year2002 & 0.69 & 0.57 & 1.22 & 0.23 & \\
\hline Year2003 & 0.51 & 0.61 & 0.83 & 0.41 & \\
\hline Year2004 & 0.78 & 0.57 & 1.38 & 0.17 & \\
\hline Year2005 & 0.96 & 0.56 & 1.73 & 0.09 & * \\
\hline Year2006 & 0.99 & 0.54 & 1.81 & 0.07 & * \\
\hline Year2007 & 1.08 & 0.56 & 1.93 & 0.06 & * \\
\hline Year2008 & 0.85 & 0.57 & 1.49 & 0.14 & \\
\hline Year2009 & 0.93 & 0.55 & 1.69 & 0.10 & \\
\hline Year2010 & 1.40 & 0.54 & 2.61 & 0.01 & *** \\
\hline$N B$ & 0.41 & 0.68 & 0.60 & 0.55 & \\
\hline$Q C$ & 0.48 & 0.58 & 0.82 & 0.41 & \\
\hline SK & 0.26 & 0.44 & 0.60 & 0.55 & \\
\hline$B C$ & 0.18 & 0.56 & 0.31 & 0.75 & \\
\hline
\end{tabular}




\section{Appendix 3.11. Multicollinearity}

The correlation matrix is suggestive of the existence of some multicollinearity. The correlation coefficient between the natural logarithm of second-quintile income and the unemployment rate for prime-age males is 0.79 . Between the dummy for BC's stricter administrative procedures in 1996 and the province's fixed effects terms, the correlation coefficient is 0.80 . And between Ontario's dummy representing stricter administrative procedures in 1996 and its provincial fixed effects term, the correlation coefficient is 0.80 . These values are all considered 'close.' Indeed, it is when the correlation coefficient between any two independent variables "is greater than 0.8 or 0.9 " that one should conclude that there is "a potentially harmful collinear relationship" (Griffiths, Hill, \& Judge, 1993, p. 435). I have therefore decided not to make corrections for multicollinearity, while acknowledging that a considerable level of multicollinearity does seem to exist. 


\section{Conclusion to Thesis}

With all three essays complete, 10 over-arching propositions can now be made with respect to research on social assistance in Canada. They are the following:

\section{An economic depression can have far-reaching implications for who is covered} by—and how much people receive on-social assistance. Admittedly, there has been just one such depression in Canada's history; but its occurrence and outcomes should be underlined. Indeed, before the Great Depression, there was virtually no government-funded social assistance system in Canada; by the end of the Great Depression, there was. What is more, Canada has never returned to a pre-Great Depression era of a near-absent social welfare system. The Great Depression signaled to Canadians that unemployment is a national issue and that a certain level of protection from unemployment was important.

\section{History suggests that Canadians collectively feel more generous after a 'nation} building' experience, and this can make a well-funded social assistance system more palatable to voters. As veterans returned to Canada after World War II, there was a growing sentiment that the social welfare needs of both veterans and civilians engaged in the war effort had to be addressed by government. This contributed to Canadians having a 'giving mood' vis-à-vis those without gainful employment, and this in turn contributed to a political climate resulting in a more robust social assistance system. 
3. Very favourable macroeconomic conditions can have important implications for social assistance coverage. Canada experienced both relatively low levels of unemployment and very high levels of tax revenue in the aftermath of the Second World War. This made it difficult to 'say no' to a gradual expansion of social assistance across Canada.

\section{Political maneuvering can play an intermediary role in determining social} assistance policy. As the $\mathrm{CCF}$ - and then the NDP_-became more popular across Canada in the 1960s, a desire by a minority Liberal government in Ottawa to 'fend off' their challenge likely contributed to the federal government implementing the CAP. Without a political threat supported by organized labour, it is possible that the CAP would never have seen the light of day.

5. Financial incentives from the federal government matter. When the federal government agreed to cost-share social assistance for employable adults, the Ontario government had a very strong incentive to expand this program. This likely contributed to the Ontario government bringing in substantial increases in benefit levels over the next 10 years.

\section{Some social assistance recipients will spend less on drugs and alcohol after} receiving increases in benefit levels. Rising social assistance benefit levels, in addition to giving recipients greater ability to afford basic necessities, may also have 
more subtle 'spillover' effects. As discussed in Essay 2, several social assistance recipients who saw a substantial rise in monthly benefit levels during the present study felt 'more hope' after the increase, opting to spend less on drugs and alcohol (even though they had more money). This warrants further research.

\section{At least in the case of singles, modest increases in SA benefit levels appear to have} only modest positive impacts on social assistance caseloads. Results of the regression done for Essay 3 suggest that modest increases in monthly benefit levels for singles would result in only very modest increases in caseloads. I would suggest that, in light of this finding, fear of rising caseloads in and of itself should not deter policymakers from bringing in modest increases to benefit levels. Put differently, fear of major caseload growth alone should not deter the Ontario government from implementing the \$100-per-month increase in monthly benefit levels for singles proposed in 2012 after a review of the province's social assistance system.

\section{When it comes to budgeting research with single adults on social assistance, it} appears possible to get reliable answers. Feedback I received from interview subjects on process in Essay 2 suggests that interview subjects felt comfortable answering very personal questions frankly. By the end of six full interviews over the course of roughly a year, respondents consistently expressed that they had confidence that honest answers to budgeting questions would not result in reprisals from welfare administrators. Further, use of Edin and Lein's budget reconciliation technique 
proved fruitful. All of this suggests that self-reporting can be reliable with these types of budget questions and this population. Other researchers should emulate this method in the future.

\section{When following social assistance recipients over time, changes in health status} may be challenging to measure. Notwithstanding the very small sample size, use of the SF-36v2 health survey in Essay 2 finds no emerging themes in terms of changes to health status following an increase in social assistance benefit levels. While use of such a health survey on a larger sample would be worthwhile, it may be that a very large sample size would be required in order to find statistically-significant findings.

\section{Relationships with the administrators of social assistance programs can} make or break the type of research done for Essay 2. While it would not have been impossible to have interviewed social assistance recipients without the cooperation of welfare administrators, it would not have been as easy. Considering that I needed to identify a specific group of recipients who met various criteria, cooperation from Toronto Social Services was critical. If similar research is undertaken in the future, cooperation from social assistance administrators will be crucial. The nurturing of such relationships very early in the research process should be a top priority of researchers. 